\title{
COMMENTAAR \\ OP DE \\ SALASILAH VAN KOETAI
}


W. Kern - 978-90-04-28641-2 Downloaded from Brill.come4/26/2023 01:53:34PM via free access 


\title{
VERHANDELINGEI
}

VAN HET KONINKLIJK INSTITUUT VOOR TAAL-, LAND- EN VOLKENKUNDE

\author{
DEEL XIX
}

\section{COMMENTAAR \\ $\boldsymbol{O P} \boldsymbol{D E}$}

SALASILAH VAN KOETAI

D O OR

Dr. W. KERN †

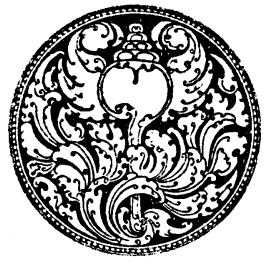

'S.GRAVENHAGE - MARTINUS NIJHOFF • 1956 
W. Kern - 978-90-04-28641-2 Downloaded from Brill.come4/26/2023 01:53:34PM via free access 


\section{T E N G E L E I D E}

De Commentaar op de Salasilah van Koetai, welke thans in druk verschijnt, werd door wijlen Dr W. Kern, taalambtenaar op Borneo, voor de oorlog voltooid en door het Koninklijk Bataviaasch Genootschap van Kunsten en Wetenschappen ter publicatie aangenomen. Door de kort daarop ingetreden oorlogstoestand kon de uitgave niet tot stand komen. Toen het manuscript na de oorlog werd teruggevonden kon helaas de auteur aan de publicatie van zijn werk zijn zorgen niet meer wijden. Verzwakt door de in Japanse krijgsgevangenschap doorstane ontberingen overleed Dr Kern na een korte ziekte op 8 Juni 1946 te Bandjermasin, zijn oude standplaats, waarheen hij zich had begeven, teneinde naast hem opgedragen ambtelijk werk, naspeuringen te doen naar zijn vroegere verzamelingen en met inspanning van alle krachten te trachten het vele, dat verloren ging, zoveel mogelijk te herstellen.

Toen in Indonesië de omstandigheden voor publicatie niet gunstig bleken te zijn, besloot het Bestuur van het Koninklijk Instituut voor Taal-, Land- en Volkenkunde de uitgave van het werk, dat een schat van gegevens op taalkundig en ethnografisch gebied bevat, op zich te nemen. Het Bestuur wil hiermede tevens de nagedachtenis eren van de jong gestorven geleerde, die in de weinige jaren welke het hem gegeven is geweest arbeid te velde te verrichten, op nieuwe terreinen, welke hij heeft angeboord, zulk belangrijk materiaal heeft verzameld.

Het werk is samengesteld als een doorlopende commentaar op de door Dr C. A. Mees uitgegeven tekst der Salasilah, welke werd gepubliceerd in zijn in 1935 te Leiden verdedigd proefschrift „De kroniek van Koetai", waarvan nog exemplaren te verkrijgen zijn bij de N.V. Uitgeverij v/h C. A. Mees te Santpoort. Komen uiteraard Dr Kern's aantekeningen eerst ten volle tot hun recht bij kennisneming van de tekstuitgave, toch zullen ook degenen, die niet over de dissertatie van $\operatorname{Dr}$ Mees beschikken, deze studie als bron van informatie betreffende de nog zo weinig bekende kustculturen en Maleise dialecten van Borneo met vrucht kunnen raadplegen. 
W. Kern - 978-90-04-28641-2 Downloaded from Brill.come4/26/2023 01:53:34PM via free access 


\section{VOORWOOR D}

In een bespreking van de dissertatie van Dr. C. A. Mees deelde ik mede, dat het in mijn bedoeling lag later een uitvoerige studie over de taal van de in dat werk uitgegeven Kroniek van Koetai en het Koetais Maleis te publiceren (TBG 1937, bl. 306). De uitgave van deze commentaar is te beschouwen als een gedeeltelijke tenuitvoerlegging van dat wel wat voorbarig geuite voornemen. Ofschoon toentertijd reeds een commentaar in schetsvorm gereed was en verschillende gegevens over het dialect van Koetai waren verzameld, bleek toch. spoedig, dat om het werk beter aan zijn doel te doen beantwoorden twee desiderata niet onvervuld konden blijven, namelijk collatie van het "Sultanshandschrift", indien dit tenminste nog bestond, en een nader onderzoek naar de taal en enkele in de Salasilah vermelde gebruiken te Tenggarong zelve. De toen niet onmiddellijk te voorziene gelegenheid daartoe verschafte mij een verblijf te Samarinda, van waaruit ik in de tweede helft van 1940 en in Januari 1941 meermalen Tenggarong bezocht. Daar mijn voornaamste werkzaamheden echter op ander terrein lagen, en ook de geschikte bronnen daarvoor niet werden aangetroffen, kon een diepgaande bestudering van het Koetaise dialect geen doorgang vinden, en werd hieraan slechts aandacht besteed, voorzover dat idioom een beter inzicht in de taal der Kroniek kon verschaffen.

Onder de velen, zo te Tenggarong als elders, die mij bij het tot stand komen van deze verhandeling op enigerlei wijze behulpzaam zijn geweest, en naar wie allen mijn oprechte dank uitgaat, moge ik hier in de eerste plaats noemen Z.H. den Sultan van Koetai. De door hem voor mijn onderzoek betoonde belangstelling bevorderde de voortgang ervan zeer, evenals de zo gastvrij geboden gelegenheid tot het bijwonen van enkele gedeelten van het in November 1940 gehouden hof-érau.

Belangrijke gegevens werden verstrekt door Pangéran Ario Tjokro, Landsgrote van Koetai, wien ik eveneens om zịn gastvrijheid en hulpvaardigheid zeer verplicht ben.

De volle last van mijn weetgierigheid kreeg $\mathrm{Ni}^{s}$ Temenggoeng, Petinggi van Kampong Pandji en rechterhand van den opperceremonie- 
meester bij de Tenggarongse hoffeesten, bijna alleen te dragen. Met hem is vrijwel de gehele tekst doorgewerkt en zeer vele gegevens zijn aan hem te danken. Het moet Pangéran Tjokro en hem tot voldoening strekken, dat de sombere voorspelling, nu ruim vijftig jaar geleden door S. W. Tromp uitgesproken, dat er na het overlijden van Pangéran Sjarif Sokmawira niemand meer zou zijn, die over de Kroniek behoorlijke inlichtingen zou kunnen verstrekken, door hen geheel kon worden gelogenstraft. $\mathrm{Ni}^{s}$ Temenggoeng was het ook, die mij het oudst bekende handschrift der Salasilah leerde kennen, door welks bestudering zo vele door de in andere handschriften overgeleverde tekst geboden moeilijkheden, die anders onopgelost hadden moeten blijven, uit den weg konden worden geruimd.

Ik mag niet verzuimen hier ook de naam te noemen van de, wat taalkundige aanleg en inzicht betreft, beste bron voor het Koetais, die ik heb gehad, den heer Joesoef Izzidin bin $\mathrm{H}$. Ishaq te Batavia. Ofschoon deze zoon van Bandjarese ouders alleen in zijn jeugd Koetais had gesproken en reeds vele jaren geleden Tenggarong had verlaten, bleken mij bij het onderzoek ter plaatse de door hem te Batavia verstrekte gegevens in alle hoofdzaken juist te zijn geweest.

Waardevolle inlichtingen werden ook ontvangen van mijn collega's Dr. Th. Pigeaud en Dr. Tjan Tjoe Siem, beiden te Jogjakarta, den heer W. F. van der Kaaden, controleur van Oost-Koetai en den heer P. Bouma van de Dienst van het Boschwezen te Samarinda. 


\section{N LEI D I N G}

\section{§1. Nieuwe handschriften.}

Tot voor kort waren er van de Salasilah van Koetai vier handschriften bekend, te weten:

1. het Berlijnse van 1849 („B”), door Dr. C. A. Mees uitgegeven in zijn dissertatie: De Kroniek van Koetai. Tekstuitgave met toelichting (Santpoort 1935);

2. het Leidse, Cod. Or. 7949, („T”), een voor S. W. Tromp in de tachtiger jaren vervaardigd afschrift in Latijns karakter van het manuscript van den toenmaligen Sultan van Koetai, waarnaar Tromp zijn uitgave van het eerste gedeelte der Kroniek bewerkte, en waarvan Dr. Mees de variae lectiones in voetnoten in zijn uitgave heeft meegedeeld;

3. het handschrift van den heer S. C. Knappert (,K”), daterend van 1899, een afschrift van hetzelfde "Sultanshandschrift”, waarvan de variae lectiones eveneens door den heer Mees zijn opgegeven, en wel als aanhangsel op zijn uitgave;

4. het Bataviase (,Tb.”), waarschijnlijk een copie van $T$, in Latijns karakter.

Voor bijzonderheden over deze handschriften kan verwezen worden naar het genoemde werk van Dr. Mees, en de tijdschriftartikelen van Tromp (De Salasila van Koetei, Bijdr. 5de Volgreeks, Dl.3, 1888, bl. 1-108), Dr. C. Snouck Hurgronje (Nog iets over de Salasila van Koetei, ib. bl. 109-120, herdrukt in Verspreide Geschriften V, bl. 145-157) en mijzelve (boekbespreking van 'Mees' dissertatie, TBG 77, 1937, bl. 294-314). In laatstgenoemd artikel werden de redenen uiteengezet, waarom een collatie van het Sultanshandschrift mij voor het verkrijgen van een duidelijk inzicht in de verhouding der handschriften en de tekst zelve noodzakelijk toescheen. In het kort komen zij hierop neer, dat de tekst, zoals hij in de uitgave voor ons ligt, niet geheel betrouwbaar is. Hs. T was immers een in veel opzichten onbetrouwbaar afschrift van het onbekende Sultanshandschrift gebleken, terwijl de in de editie-Mees gegeven transcriptie van het Berlijnse handschrift op verschillende belangrijke punten twijfel aan haar juistheid 
deed rijzen. De variae lectiones uit $\mathrm{K}$ droegen weliswaar veel bij tot de verbetering van ons inzicht in de waarde van $\mathrm{T}$ en zijn verhouding tot zijn voorbeeld, doch voor het vaststellen van een groot aantal lezingen bleef het raadplegen van een goede tekst in Arabisch karakter vereiste. Het Sultanshandschrift scheen het enige bereikbare van die aard in Indië, en zo was mijn streven bij mijn bezoek aan de hoofdplaats van Koetai er in eerste aanleg op gericht deze grote onbekende in handen te krijgen.

De navraag naar handschriften der Salasilah, welke men ter plaatse gewoonlijk Sersilah of ook wel Tersilah noemt, leverde te Tenggarong drie exemplaren op. Het eerste, dat mij aanvankelijk werd getoond als „het enige", bleek dicht bij $\mathrm{K}$ en $\mathrm{T}$ te staan, en was, naar later bleek, eveneens een afschrift van het Sultanshandschrift. Het manuscript, hier "Sa" genoemd, is ongedateerd, en onderscheidt zich van de andere, doordat het na het verhaal over Marhoem Moearabangoen, dat ook in de beneden te noemen handschriften voorkomt, nog een toevoeging in moderner taal bevat, historische notities, voornamelijk de geschiedenis van Petta To Sibengarang, den Wadjoresen schoonvader van Sultan Moehammad Idris, betreffende. Het is een slecht afschrift en bevat veel omissies, spelfouten en dwaze veranderingen, en steekt daarin ongunstig bij $\mathrm{K}$ en $\mathrm{T}$ af. Bij de vergelijking der handschriften kan het gevoegelijk buiten beschouwing worden gelaten.

Het Sultanshandschrift, dat pas na lang zoeken werd aangetroffen onder de nagelaten papieren van den in Februari 1940 overleden Pangeran Sosronegoro, is een gebonden exemplaar, geschreven op Hollands papier, hier genaamd kertas Arab, met als watermerk G. W. J. Pannekoek op de ene, en een afbeelding van de Nederlandse leeuw omgeven door de spreuk Concordia Res Parvae Crescunt op de andere bladhelft. Het formaat der bladzijden is $20 \times 34 \mathrm{~cm}$, dat der bladspiegel $12 \times 22,5 \mathrm{~cm}$. De Salasilah beslaat hierin 152 bladzijden - volgens de telling van het handschrift, waarbij van 89 op 100 wordt overgesprongen, 162 bladzijden. De eerste bladzij is verloren gegaan, de tweede vertoont een kleine bladspiegel, omgeven door een schets van arabesken in inkt en potlood, blijkbaar een onvoltooide poging tot navolging van de verluchting van het hieronder te bespreken handschrift $\mathrm{N}$. B1. 163-164 bevatten een kort verhaal over zekeren Marhoem Moearabangoen uit Berau, en de uit zijn huwelijk met Adji Galoeh Besar van Koetai voortgevloeide verwikkelingen. De colophon op bl. 165 luidt in transcriptie: „setelah chatam ini soerat sersilah didalam bandar negeri Koetai Tinggarong daérah didalam karaton kepada doea poeloeh satoe 
hari boelan دالحج (Dhoel-hiddjah) jaïtoe kepada hidjrat annabi s.a.a.w. sanat 1285 déwasa itoelah jang (e)mpoenja pekerdjaan entji ${ }^{s}$ Moehammad Tajib bin Malim Kamim Kajoetangi." Hierna volgen nog een aantal blanco vellen, waarna acht bladzijden met stamboomtekeningen, nakomelingen van Sultan Moehammad Salihoeddin betreffende. Het schrift is fraai en regelmatig. Voor het aangeven van nieuwe pericopen en vorstelijke namen is rode inkt gebezigd, evenals dat door Dr. Mees voor hs. B is beschreven.

Dit handschrift (,S"), dat van A.D. 1869 dateert, is dus inderdaad jonger dan het Berlijnse, zoals reeds door Dr. Mees op niet geheel voldoende gronden werd vermoed. Toen Tromp, die constateerde, dat het er niet zeer oud uitzag, het raadpleegde, was het dus pas een jaar of vijftien oud. Een globaal onderzoek toonde aan, dat dit manuscript inderdaad het voorbeeld van zowel $\mathrm{T}$ als $\mathrm{K}$ is geweest. O.a. bleken de in Bespr. 297 bedoelde zinstorende leemten in $\mathrm{T}$ en $\mathrm{K}$ alle op $\mathrm{S}$ terug te gaan. Beide genoemde afschriften hebben overigens hun origineel tamelijk nauwkeurig gevolgd, hs. $\mathrm{K}$, dat zich eveneens van het Arabische schrift bediende, natuurlijk het best. De afschrijver van S kwam, zoals hij in de colophon vermeldt, uit Kajoetangi (Martapoera). Hij was dus. wat Tromp reeds vermoedde, een Bandjarees (vgl. Bespr. 300).

De moeite van een volledige collatie van het Sultanshandschrift kon ik mij besparen, daar er inmiddels van geheel onverwachte zijde nog een ouder manuscript te voorschijn was gekomen, dat al spoedig bleek niet alleen het directe voorbeeld van $\mathrm{S}$ te zijn geweest, doch ook van het Berlijnse handschrift, dat tot nu toe voor het oudst bestaande was gehouden. Het exemplaar (,N”), dat deze onverwachte en hoogst welkome verrassing bracht, en dat zich thans in het bezit van $\mathrm{Ni}^{\text {s }}$ Temenggoeng bevindt, trok reeds door zijn uiterlijk de aandacht. De twee eerste pagina's, waarvan de tekst slechts een kleine bladspiegel vult, zijn namelijk met kleurige arabesken geillumineerd, zoals men dat van Koran-exemplaren kent. In de versieringen treft men met gouden letter op paars fond een legende aan, die $i k$, rechtsboven beginnend, als volgt lees: ,al-soeltan Moehammad Salihoeddin ibn al-marhoem / al-soeltan Moehammad Moeslihoeddin ibn / al-marhoem al-soeltan Moehammad cAlioeddin ibn al-mar/hoem al-soeltan Idris" 1), gevolgd door een Arabische spreuk, waarvan ik de juiste lezing niet heb kunnen vaststellen.

1) De genoemde vorsten hebben in de opgegeven volgorde geregeerd. Soeltan 'Alioeddin was echter niet een zoon, doch een broeder van Sultan Moehammad Idris, den vader van Moehammad Moeslihoeddin. 
Het handschrift is geschreven op Hollands papier met het watermerk „W. W. en H. Pannekoek” op de ene, en een voorstelling van de Nederlandse Maagd met vrijheidshoed en de zinspreuk Pro Patria op de andere bladhelft. Het eerste katerntje, eveneens van Hollands papier, draagt het watermerk DKMO. Het formaat is $24 \times 34 \mathrm{~cm}$, de bladspiegel is groot $15 \times 25 \mathrm{~cm}$, met 25 regels per bladzijde.

De paar bladzijden, die aan de tekst voorafgaan, zijn gedeeltelijk gevuld met genealogische aantekeningen betreffende de kinderen van Sultan Moehammad Salihoeddin. Ook wordt er een, naar men zegt eigenhandige, aantekening van Sultan Soelaiman in aangetroffen, waarin wordt geconstateerd, dat op 16 Djoemādoel-achir 1275 de dagen zijns levens 9837 waren, later vermeerderd met de opmerking, dat deze 12778 waren op de tiende Rabicoel-awwal 1284, opgaven, die moeilijk met elkaar en evenmin met zijn geboortedatum (zie beneden) in overeenstemming zijn te brengen.

Helaas ontbreken aan het eind enige, naar schatting zes bladzijden, waarin zich vermoedelijk de colophon heeft bevonden. De laatste bladzijde (121) eindigt namelijk met het woord Maharadja van 257/25 der editie-Mees, terwijl de rakibah (,custos”) nog de woorden Telikat kepada Narangbaja te zien geeft. Tegen de omslag geplakt zit nog een gedeeltelijk beschreven pagina, die het laatste gedeelte der bovengenoemde geschiedenis van Marhoem Moearabangoen bevat. De „soerat peringatan akan perdjandjiannja Boegis dengan radja Koetai", welke het slot van B vormt, zal, daar zij in S en het straks te noemen hs. I ontbreekt, ook in $\mathrm{N}$ niet gestaan hebben.

Uit de vermelding van Sultan Moehammad Salihoeddin in de illuminatie bovenaan de eerste bladzijde en de aantekeningen omtrent de geboorte van zijn twaalf kinderen vóór in het handschrift mag men opmaken, dat dit niet alleen zijn handexemplaar is geweest, doch ook tijdens zijn regeering vervaardigd is, dit is tussen de jaren 1816 en 1845. Over de mogelijkheid de tijd van ontstaan nader te begrenzen zal beneden nog gesproken worden.

Hoe en wanneer dit manuscript, dat met meer recht dan S aanspraak op de titel "Sultanshandschrift" zou kunnen maken, uit de kraton is verdwenen, is onbekend. Blijkens Sultan Soelaimans aantekening over zijn leeftijd in 1284 der Mohammedaanse jaartelling, d.i. A.D. 1867, aan welker authenticiteit er geen reden is om te twijfelen, was het in dat jaar nog in diens handen. Doch toen Tromp nog geen twintig jaar later zich voor de Salasilah interesseerde, was het handschrift, dat men hem toonde, en ,dat buiten den Sultan slechts aan een zeer enkelen 
vertrouweling bekend" was, niet het onderhavige, doch het van 1869 daterende afschrift S. Vermoedelijk was het origineel toen reeds in andere handen, tenzij men hem dat om bepaalde redenen niet heeft willen laten zien, hetgeen, gezien de vriendschappelijke voet waarop Tromp met het Sultanaat stond, niet zeer waarschijnlijk is.

Terugkerende tot het uiterlijk van hs. $\mathrm{N}$ merken wij op, dat het in een weinig fraaie, ongeoefend aandoende, doch zeer duidelijke hand is geschreven. Evenals in B en S worden het begin van nieuwe pericopen en de namen van tot het vorstenhuis behorende personen gemeenlijk met rode inkt geschreven. De spelling is onbeholpen en onregelmatig. De eigenaardigheden door Snouck Hurgronje, t.a.p. bl. 112 v. voor B opgegeven, blijken grotendeels op dit handschrift terug te gaan. Alleen

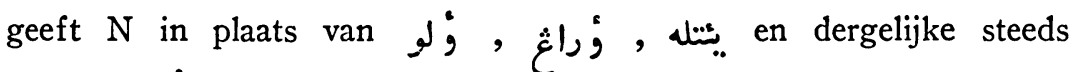
ا.ئنله , اؤ راغ , اؤلو . Voor verdere bijzonderheden kan naar genoemd artikel worden verwezen. Opmerking verdient echter nog, dat de hamzah aan het eind van woorden behalve door 3 en ; ook sporadisch wordt weergegeven met een $\mathcal{E}$, als in مرغكع (merangkas),

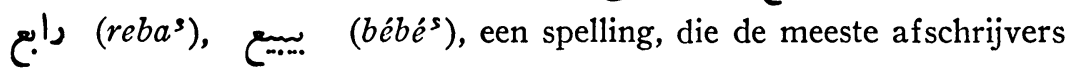
op een dwaalspoor heeft gebracht. In het woord maksoed, massoet uitgesproken, wordt deze letter enige malen als sluiter der eerste lettergreep geschreven ( معصود en معسود naast مأسود ). De verbinding der letters is willekeurig, prefixen en suffixen worden gemeenlijk los van het grondwoord geschreven, evenals de nadrukswijzers lah en poen. Daarentegen wordt jang vaak aan het volgende woord vastgekoppeld, en worden ook andere woorden soms aan elkaar gesmeed in de spelling. Men vergelijke bijvoorbeeld جائ تن لاير , Djaitan

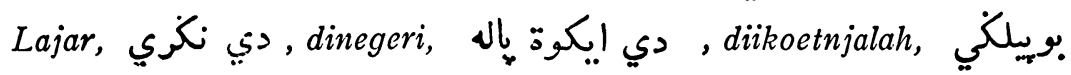
boenji lagi. Over het algemeen zijn de klinkers oe en $i$ ook in gesloten lettergrepen door wau en $j a$ aangegeven. Het ontbreken daarvan wijst gewoonlijk, doch ook weer niet altijd, op de uitspraak $e$ of $a$. Anderzijds ontbreekt de alif nog al eens in de open lettergreep, waar men hem zou verwachten, zoals in het laatste der boven gegeven voorbeelden en mendapat. Veelvuldig staat dit teken echter juist waar $e$ moet worden gelezen. Enkele malen wordt. gebruik gemaakt van 
klinkertekens om de uitspraak van een woord aan te geven. Dit geschiedt vooral bij Javaanse woorden, waarin de $\stackrel{a}{\text {-klank }}$ wordt weergegeven met $\dot{\jmath}$, welk teken ook gebruikt wordt voor $\bar{o}$, een klank gelijkend op onze gesloten $o$ en evenals deze gerekt, die in het Koetais in enkele aan het Toendjoengs ontleende woorden voorkomt. Op het punt van diacritische tekens is het handschrift zeer nauwkeurig te noemen. Ook $k$ en $g$ worden bijna altijd behoorlijk onderscheiden.

Prof. Snouck Hurgronje heeft t.a.p. ook gewezen op „het misbruik, dat in het handschrift gemaakt wordt van de angka $Y$." Dit geldt niet voor hs. $\mathrm{N}$, behalve in die gevallen, waar het teken niet gebezigd is om woordverdubbeling aan te duiden, doch herhaling van hetzelfde woord in de zin, zoals bijvoorbeeld in de ook in het bedoelde artikel angehaalde zin (ed.-Mees 126/3): egoeng itoe didjoendjoeng oléh naga ${ }^{2}$ didjoendjoeng oléh lemboe, waar wij ,naga, naga" moeten lezen. Dit is inderdaad een minder wenselijke toepassing van het verdubbelingsteken, die overigens veel in Maleise handschriften wordt aangetroffen. Het gebruik van de angka $r$ in $\mathrm{B}$, waar noch van woordverdubbeling, noch van woordherhaling sprake kan zijn, is echter meermalen te verklaren als een gevolg van het gebruik, zo men wil ook ,misbruik" van dat teken, dat de schrijver van $\mathrm{N}$ heeft gemaakt. namelijk als verwijzingsteken voor overgeslagen woorden of stukken van zinnen, die in margine zijn ingevoegd. Het teken is dan boven de plaats, waar de invoeging moet geschieden, gezet, en a chter het in margine ter invoeging geschrevene, in tegenstelling tot de gewoonte in andere handschriften, waar het vooór deze pleegt geplaatst te worden. De schrijver van B heeft de waarde van dit teken niet begrepen en het in margine staand als verdubbelingsteken opgevat (zie bijvoorbeeld de aantekeningen bij 124/13 en 209/10). S daarentegen heeft er. geen moeilijkheden mee gehad. In het laatste gedeelte van $\mathrm{N}$ wordt voor de verwijzing tweemaal gebruik gemaakt van de angka $r$, wat minder gevaar voor vergissingen oplevert.

Wat de verhouding tussen de afschriften $\mathrm{S}$ en $\mathrm{B}$ tot hun origineel betreft, kan opgemerkt worden, dat zij het over het algemeen trouw hebben gevolgd. Omissies komen natuurlijk bij beide voor, evenals verknoeiingen door misverstaan van de tekst, doch hierin gaan $z i j$ zelden samen. Werkelijke verbeteringen van lezingen van $\mathrm{N}$ beperken zich tot zulke, die iedere lezer voor zich stilzwijgend zou aanbrengen. Slechts bij hoge uitzondering, indien ik mij niet vergis slechts tweemaal, 
is een niet zo voor de hand liggende verbetering door beide afschrijvers gelijkelijk aangebracht (154/31 en 173/27).

Een vierde, tot voor kort onbekend handschrift werd in de zomer van 1939 op een der zolders van het Museum voor Natuurlijke Historie te Leiden gevonden tussen een collectie Indische naturalia, waarna het is opgenomen in de collectie van Maleise handschriften der Leidse Universiteitsbibliotheek (Cod.Or. 6825) ${ }^{1}$ ). Het bestuur van het Koninklijk Instituut voor de Taal-, Land- en Volkenkunde van Ned.-Indië liet van dit handschrift twee fotografische reproducties vervaardigen, waarvan er een aan het Bataviaasch Genootschap werd geschonken bij het schrijven van den Secretaris van genoemd Instituut, do. 24 Februari 1940 , waaraan de hier vermelde bijzonderheden zijn ontleend. Op grond van de prachtige, haarscherpe reproductie (Mal. hs. K.B.G. 461), kan nog het volgende over dit handschrift (hier „I” genoemd) worden meegedeeld. Het is groot 120 bladzijden, geschreven op foliopapier in kolommen van $27-28$ regels, welke een breedte van 9,5 bij een hoogte van 25 à $26,5 \mathrm{~cm}$ hebben. Het soms wat gedrongen schrift is zeer duidelijk. De bladzijden 21-35 dragen de sporen van door een Europeaan gelezen te zijn in enkele transcripties en verbeteringen in Latijns schrift. Daar bl. 21 van dit hs. correspondeert met bl. 144 der editie-Mees, dus volgt ná het door Tromp gepubliceerde fragment, is het waarschijnlijk, dat deze aantekeningen zijn geplaatst door iemand, die met Tromp's in 1888 geschreven artikel bekend was. Het handschrift bevat hetzelfde als het boven besproken hs. S, dus de eigenlijke Salasilah gevolgd door het verhaal over Marhoem Moearabangoen. De colophon, die volgt na de eigenlijke Salasilah (bl. 118), luidt: „tammat allah (lees lah) soerat asal radja2 dinegeri Koetai Kartanegara kepada dalapan likoer hari boelan djoemādoel-awwal tahoen bā's kepada jaum assoeloes ( السولوس ) kepada tarich 1248." Dit jaartal correspondeert met 23 October 1832, waarmee dit handschrift dus het oudst gedateerde is, dat wij bezitten. Het is echter niet werkelijk het oudste, daar de vergelijking aantoont, dat ook dit hs. een rechtstreeks afschrift van $\mathrm{N}$ moet zijn, evenals B en S. Evenals in deze afschriften komen hier verscheidene, gewoonlijk weer andere, fouten, berustend op misvattingen en verlezingen van het origineel in voor. Het schijnt mij echter toe - het loont de moeite niet dit tot in finesses na te gaan - dat dit afschrift van de drie het getrouwst aan zijn origineel is. Aan opzette-

1) Vgl. over dit hs. Ph. S. van Ronkel, Eene nieuwe uitgave van de kroniek van Koetai, BKI 100, 1941, bl. 405 v., met een facsimilé. (Noot v. d. red.) 
lijke tekstverbetering heeft de afschrijver zeer weinig gedaan, en zelfs evidente verschrijvingen van $N$ (bv. 154/31, 162/6, 168/8, 173/27) heeft hij klakkeloos - of was het uit wetenschappelijke zin of op speciaal bevel? - overgenomen. Uit de vele bewijzen, dat I inderdaad een afschrift van $\mathrm{N}$, en de verhouding niet soms omgekeerd is, kan worden volstaan met de vermelding, dat het op 122/3 samengaat met $B$ (onmisbare alleen in de rakibah bij $\mathrm{N}$ voorkomende woorden overgeslagen) en dat het op 154/10 zowel van $B$ als $S$, die hier verschillende lezingen hebben, afwijkt, ten gevolge van de onduidelijke invoeging van een zinsnede in margine bij $\mathrm{N}$.

$\mathrm{Nu}$ met $\mathrm{N}$ de archetypus bekend is geworden, levert de vergelijking van I, welke anders van de hoogste waarde geweest zou zijn, bijna geen belangrijke gegevens op, behalve voor de laatste thans in $\mathrm{N}$ ontbrekende bladzijden, zodat het slechts bij hoge uitzondering in de volgende aantekeningen behoeft te worden vermeld. Het meest waardevolle van dit handschrift is ongetwijfeld de boven aangehaalde colophon. Is deze werkelijk afkomstig van den afschrijver, dan hebben wij hiermede het bewijs, dat $\mathrm{N}$ van nog oudere datum dan October 1832 moet zijn. Het is echter zeer wel mogelijk, dat de datering is afgeschreven van de thans verloren gegane colophon in N. Vooral, indien het juist is, hetgeen ik geneigd ben aan te nemen, dat een Europeaan afschrift I voor zich heeft laten vervaardigen. Deze aanname berust voornamelijk op de ,zakelijkheid" der inrichting ervan, met name de bladverdeling, waarbij de helft der bladzijden is opengelaten, klaarblijkelijk ten behoeve van het plaatsen van aantekeningen of een vertaling, en het feit, dat de kleine bladspiegel der eerste twee bladzijden in $\mathrm{N}$, die in alle in Arabisch karakter geschreven manuscripten der Salasilah is nagevolgd, hier niet wordt gevonden. Zolang over I echter geen nadere bijzonderheden zijn te verkrijgen, zal de kwestie der datering van $\mathrm{N}$ wel onbeslist moeten blijven. In dit verband moet nog gewezen worden op één gegeven voor approximatieve datering, dat de tekst ons zelve verschaft. De laatste woorden vóór de colophon namelijk luiden (geciteerd naar I): ,adapoen soeltan membawa oedjoeng 5 (in Eur.Arabisch cijferschrift) orang". Met den sultan kan niemand anders dan Moehammad Salihoeddin bedoeld zijn, zoals B het dan ook heeft opgevat. Wanneer nu met zekerheid kon worden vastgesteld, wie het vijfde van zijn kinderen was en wanneer dit was geboren, zouden wij in deze van $\mathrm{N}$ afkomstige mededeling een prachtige terminus post quem voor de vervaardiging van onze archetypus hebben, en in de geboortedatum van het zesde kind de terminus ante quem. $\mathrm{Nu}$ is volgens de 
aantekeningen vóórin $\mathrm{N}$ de latere sultan Soelaiman, die de vijfde der twaalf aldaar genoemde kinderen van sultan Salihoeddin was, echter eerst geboren op 12 Dhoel- $\mathrm{Ka}^{c} \mathrm{dah} 1253$ (1838), dus ongeveer zes jaren later dan de datering in hs. I. Vermoedelijk waren er dus onder de vijf in hs. I genoemde kinderen enigen verwekt bij „orang keloearan”, die in de genoemde aantekeningen in $\mathrm{N}$ niet vermeld zijn. Ik heb hierover echter geen nadere inlichtingen kunnen verkrijgen. Over de geboortedatum van sultan Soelaiman bestaat enige onzekerheid - sommigen zeggen, dat hij in 1833 is geboren - doch de bovenaangehaalde datum wordt bevestigd door de mededeling van Gallois (Korte aanteekeningen gedurende eene reis langs de Oostkust van Borneo, BKI 4, 1856, bl. 224 v.) dat de sultan van Koetai in 1850 pas 12 jaar oud was.

De onderlinge verhouding der acht thans bekende handschriften der Salasilah kan nu aldus worden voorgesteld:

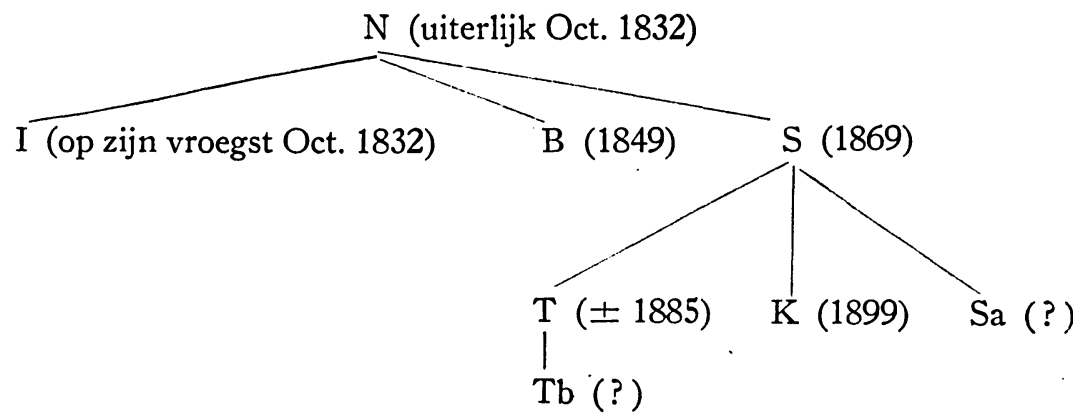

\section{§ 2. Inrichting en aard van de commentaar.}

Het zou mij het liefst zijn geweest om een diplomatische heruitgave in Arabisch schrift te geven van het tot nu toe oudste bekende handschrift $\mathrm{N}$, waarbij de lezingen der andere handschriften bijna geheel genegeerd zouden kunnen worden, doch om redenen van practische aard is hiervan afgezien. Om het gemis aan een dergelijke reproductie van $\mathrm{N}$ zoveel mogelijk te vergoeden, wordt in de commentaar een volledige collatie van $\mathrm{N}$ met de op $\mathrm{B}$ berustende tekst der editie-Mees opgenomen ${ }^{1}$ ). Volledig is deze collatie in zoverre, dat ook van alle

1) Voor de laatste in $\mathrm{N}$ ontbrekende bladzijden zijn I en $\mathrm{S}$ gecollationneerd. Ofschoon $\mathrm{S}$ grotendeels overeenkomt met zijn afschrift $\mathrm{K}$, is toch, ter vermijding van hinderlijk naslaan, niet naar de door Mees in het aanhangsel op zijn uitgave opgegeven variae lectiones van dit handschrift verwezen. De vergelijking van de lezingen der handschriften I, B en S kan ons in vele gevallen zonder moeite de oorspronkelijke lezing van $\mathrm{N}$ doen herstellen. 
kleine verschillen ten aanzien van de al of niet aanwezigheid van voegwoorden, nadrukswijzers, woordverdubbeling, pronominale suffixen e.d. rekenschap is afgelegd, ook in die gevallen, waar $\mathrm{N}$ zeker onjuist is of waar de zin van de tekst niet in het geding schijnt te zijn. Dit laatste mag voor een uitgever geen reden zijn afwijkende lezingen te verzwijgen, daar zijn opvatting van bepaalde passages, hoe voor de hand liggend ook in zijn ogen, niettemin verkeerd kan zijn. Onze tekst geeft er bovendien meer dan één voorbeeld van, hoe een enkel maka of $-n j a$ meer of minder een onduidelijke passage verstaanbaar kan maken.

De opgaven der lezingen van $\mathrm{N}$ zijn zo kort mogelijk gehouden. Vaak was het niet nodig om de lezing der editie ook te vermelden. Als bijvoorbeeld voor 122/15 wordt opgegeven „N berapa”, dan betekent dat, dat $\mathrm{N}$ deze lezing vertoont in plaats van het enige daarop gelijkende woord in de bedoelde regel der editie-Mees, namelijk beberapa. Evenzo staat 125/1 „N laloelah" voor laloe in de tekst, 118/6 „N masing” voor masing-masing e.d. Dr. Mees paste dezelfde methode toe voor de opgave der variae lectiones van $\mathrm{K}$. Als $\mathrm{N}$ dezelfde lezing als $\mathrm{T}$ volgens een voetnoot der uitgave vertoont, dan is dat weergegeven met ,als Tnt." met het nummer van de noot. Wanneer $\mathrm{N}$ samengaat met een in een voetnoot verwerkte lezing van B vindt men ,als Bnt.". Indien $\mathrm{N}$ een of meer woorden meer heeft dan de uitgave, dan is alleen het woord waarachter de invoeging moet plaatshebben opgegeven: „118/3 $\mathrm{N}$ orang na seorang" betekent dus, dat $\mathrm{N}$ daar seorang orang toea iplv. seorang toea leest. Waar B een of meer woorden meer heeft dan $\mathrm{N}$ is dat gemakshalve aangegeven met „N ontbr.” voor ,ontbreekt bij N", hoewel het gebruik van deze term strikt genomen niet juist is.

Op het punt van de spelling kon niet dezelfde volledigheid worden betracht. Het was ondoenlijk in alle gevallen, waar de spelling door Dr. Mees is aangepast aan de spelling van Van Ophuijsen (vgl. Bespr. 298 vv.), die van $\mathrm{N}$ weer te geven. Stilzwijgend zijn over het algemeen voorbijgegaan het al of niet voorkomen van initiale of intervocalische $h$, de schrijfwijze van de pepct met alif, de verschillende schrijfwijzen voor eind-hamzah e.d. Zelfs als $\mathrm{N} b a$ - of $b e$ - heeft in plaats van ber-, is dat niet steeds verantwoord. Wanneer echter een woord uit hs. $\mathrm{N}$ moest worden aangehaald, dan is zoveel mogelijk de spelling van het handschrift gevolgd. Als dus bijvoorbeeld de editie kekallah heeft, $\mathrm{N}$, dan is kakal getranscribeerd, in navolging van de spelling van het manuscript, niet ter navolging in de uitspraak. $Z_{0}$ is ook bij aanhalingen uit $\mathrm{N}$ de angka $\vee$ uitgedrukt door het cijfer 2 . 
De schrijfwijze van de pepet met alif, die in alle handschriften der Salasilah zo storend werkt, en die naar alle waarschijnlijkheid voornamelijk haar oorzaak vindt in de Bandjarese moedertaal der afschrijvers, wordt soms ook aangetroffen in stukken van rasechte Koetaiers, wier uitspraak deze spelling geenszins rechtvaardigt. Dit moet echter eveneens aan Bandjarese invloed worden toegeschreven, eensdeels door het voorbeeld van de Bandjarese schrijvers, die te Tenggarong emplooi vonden, andersdeels ook doordat, naar men gezien de invloed der Bandjarezen in Koetai in het algemeen mag aannemen, de meeste godsdienstige en belletristische litteratuur in Koetai van Bandjarees-Maleise oorsprong was. Van het bestaan hebben van een levendige litteraire activiteit, zoals men die in het Bandjarese heeft gekend, is mij in Koetai niets gebleken. Indien men zeker weet met een stuk van onverdacht Koetaise herkomst te doen te hebben, wat echter maar zelden het geval zal zijn, beantwoordt de transcriptie met $e$ in het bedoelde geval beter aan de bedoeling van den schrijver dan de letterlijke navolging van het handschrift. In de uitgave der korte versie van de Salasilah, welke door een Koetainees is geschreven, heb ik haar dan ook zonder aarzelen toegepast. $\mathrm{Bij}$ de weergave van lezingen van $\mathrm{N}$, waarbij de bedoeling voorzat de aard van dat handschrift zo nauwkeurig mogelijk door het inadaequate medium van het latijnse schrift te doen uitkomen, kon dit natuurlijk niet geschieden.

Bij de eigenlijke commentaar is eveneens gestreefd naar kortheid, voornamelijk door bij het voorkomen van een reeds besproken woord niet te verwijzen naar de betreffende aantekening, en door als regel alle afleidingen van een grondwoord, die in de tekst voorkomen, te bespreken op de plaats, waar er het eerst een wordt aangetroffen. Met behulp van de klapper kan men onmiddellijk vinden of, en zo ja, waar een woord met zijn eventuele afleidingen besproken is. Overigens volgen de aantekeningen de tekst regel voor regel en woord voor woord. Verbeteringen van lezingen in de editie, al of niet naar $\mathrm{N}$, zijn, ook wanneer dezelfde enige malen op één bladzijde moeten worden aangebracht, telkens bij de betreffende regel opgenomen. Alleen bij op elkaar volgende of niet ver uiteenstaande regels is hiervan bij uitzondering afgeweken. Hierdoor zal men in staat zijn van iedere gewenste regel in de editie in een oogopslag vast te stellen, hoe de lezing van $\mathrm{N}$ is en of tekstverbetering dient te worden overwogen. Men houde er mee rekening, dat de commentaar zich voornamelijk met de door $\mathrm{N}$ gegeven vorm van de tekst bezighoudt. Bij aanhalingen van zinnen uit de tekst wordt dus steeds de lezing van $\mathrm{N}$ gevolgd, wat de spelling 
betreft echter slechts in zover deze in de aantekeningen ter plaatse is weergegeven.

Het scheen mij onnodig toe de in de editie ten opzichte van de spelling van Van Ophuijsen gemaakte fouten (vgl. Bespr. 303) steeds te verbeteren, al heb ik soms waar misverstand mogelijk scheen met „t.r. ...." een spelling herzien.

Hoe meer men de Salasilah bestudeert, hoe meer men tot de overtuiging komt, dat de tekst, die wij thans kennen, ook in zijn oudste en beste vorm, handschrift $\mathrm{N}$, vele corrupte plaatsen vertoont. Waar een plaats mij verminkt toescheen, is dat, voorzover niet getracht werd haar bij conjectuur te verbeteren, aangegeven. Kleine ongeregeldheden in de zegswijze en minder "logische" uitdrukkingen of schrijffoutjes van ondergeschikt belang, zijn evenmin als niet storende drukfouten in de uitgave gesignaleerd.

De commentaar heeft voornamelijk ten doel de tekst taalkundig op te helderen. Het criterium voor de bespreking van woorden is het ontbreken in de Maleise woordenboeken, hetzij van het woord zelf, hetzij van de betekenis waarin het in de Salasilah verschijnt, en soms ook van de vorm der afleiding van een overigens bekend grondwoord. Als maatstaf heb ik zoveel mogelijk de derde druk van het Nieuw MaleischNederlandsch Woordenboek van H. C. Klinkert (1916) genomen. Ofschoon Wilkinson's Malay-English Dictionary (1932) wat betreft het aantal opgenomen grondwoorden en de definitie der betekenissen over het algemeen veel beter is, schiet het tekort in de opgave van afgeleide vormen, ook wanneer de betekenis daarvan niet onmiddellijk volgens de regels der grammatica uit die van het grondwoord is af te leiden, wanneer dus ook de afgeleide vormen op het terrein der lexicografie thuis behoren. Bovendien kon niet worden aangenomen, dat dit woordenboek in handen was van ieder, die zich voor de Salasilah zal interesseren. Zo zijn verschillende, met name uit het Javaans ontleende woorden, die men in dat woordenboek verklaard vindt, toch opgenomen. Verder zijn in de tekst voorkomende Koetaise woorden, die men ook kan vinden in het Maleisch-Nederlandsch Woordenboek van $H$. von de Wall en Van der Tuuk's Aanhangsel daarbij, die helaas langzamerhand in het vergeetboek beginnen te raken, niettemin in de commentaar besproken, alleen dan met opgave van deze bron, wanneer de hierdoor gegeven verklaring mij niet geheel juist voorkwam of ik er geen bevestiging van kon krijgen. Op dezelfde wijze werd gehandeld met Tromp's verklaringen, voorzover zij zuiver Koetaise woorden betreffen. Javaanse leenwoorden zijn, voorzover in Klinkert ontbrekend, zonder onderscheid 
opgenomen, hoe algemeen bekend sommige ook geacht mogen worden te zijn en zonder dat rekening is gehouden met de moderne Maleise schrijf- en beschaafde omgangstaal, die men niet onaardig wel „basa podium" noemt.

Vermoedelijk zal van sommige woorden een betekenis Koetais worden genoemd, die in werkelijkheid algemeen Maleis is. Door de onvolledigheid van onze woordenboeken is dit euvel onvermijdelijk. Men neme in dit verband in aanmerking, dat in de antekeningen met "Maleis” het z.g. Riouw-Maleis der woordenboeken, met name dat van Klinkert bedoeld wordt.

Voor de etymologische vergelijking van dialectische woorden heb ik mij in hoofdzaak beperkt tot andere Maleise dialecten, voorzover gegevens daarover tot mijn dienst stonden. Hierbij is ook enige aandacht besteed aan de taal der zogenaamde "Sea Dyak" van Serawak en West-Borneo, welke dicht bij het Maleis staat en juist voor de vergelijking met de Maleise dialecten van Borneo van veel belang is. Uit het druk gebruik, dat bij de comparatio van het Bandjarees is gemaakt, make men niet op, dat dit Maleise dialect zo bijzonder nauw verwant is aan het Koetais. Het vindt meer zijn oorzaak in het feit, dat schrijver dezes van dit levende Maleise idioom de meeste studie heeft gemaakt en in de overweging, dat het een onmiskenbare invloed op het Koetais heeft uitgeoefend en daar nog mee voortgaat. Overigens staat het in vele opzichten verder van het Riouws af dan het Koetais.

Naar de localisatie van aardrijkskundige namen is geen diepgaand onderzoek ingesteld. Voorzover zij ook voorkomen op de internationale kaart van Borneo zijn zij bekend verondersteld. Omtrent vele andere namen kon ik noch bij mijn helpers te Tenggarong, noch bij de Topografische Dienst te Samarinda opheldering verkrijgen. Zulke namen, waarvan de meeste nog wel plaatselijk bekend zullen zijn (vgl. Tromp, bl.7) en sommige waarschijnlijk op door mij niet geraadpleegde kaarten zijn te vinden, zijn met een vraagteken in de commentaar opgenomen. Evenmin is bijzondere zorg besteed aan de vaststelling van de juiste vorm en uitspraak der eigennamen in de opsommingen aan het eind der kroniek. Wat hierover is opgemerkt berust op losse en niet steeds volkomen betrouwbare inlichtingen.

\section{§ 3. Enkele opmerkingen over taal en stijl der Salasilah.}

De taal der kroniek kan men ruwweg karakteriseren als litterair Maleis met Koetaise inslag. Het Koetaise element wordt voornamelijk uitgemaakt door : 
1. In het Maleis niet bekende woorden.

2. Afwijkende betekenis van ook in het Maleis voorkomende woorden.

3. Het gebruik van andere formantia dan in het Maleis bij afleidingen van bepaalde grondwoorden zonder onderscheid in betekenis ( $-i$ iplv. -kan, $b e(r)$ - iplv. me- en omgekeerd).

4. Enkele zeldzame gevallen van niet in het Maleis of in die taal in een andere betekenis gebruikte vormen.

5. De vorm van enkele prefixen (be-, pe- en te-iplv. ber-, per- en ter-).

6. De uitspraak, voorzover die uit de spelling is op te maken.

Aangaande de eerste vijf punten geven de aantekeningen voldoende opheldering. Wat het zesde betreft valt op te merken, dat de spelling, waarschijnlijk dank zij de ongeletterdheid van den schrijver, vaak meer fonetisch is dan in andere Maleise handschriften het geval pleegt te zijn. Zo bijvoorbeeld in het veelvuldig ,ontbreken" van initiale en intervocalische $h$ als in oeloe, ilir, saoet, liat, daoeloe e.d. naar de uitspraak. Verder in de veel voorkomende schrijfwijze van de eind- $k$ met hamzah. Bij het hieromtrent in Bespr. $301 \mathrm{v}$. te berde gebrachte kan nog gevoegd worden, dat de uitspraak der eind- $k$ als ,opgeslokte $k$ " in het Koetais, anders dan in het Maleis, doch evenals in het Minangkabaus en het Midden-Maleis, ook in afleidingen met de suffixen -an en $-i$ behouden blijft. Voor het Koetaise taalbewustzijn kan er dus al zeer moeilijk enig verschil bestaan tussen de uit $k$ ontstane hamzah in woorden als manos en $a n a^{s}$, en die in oorspronkelijk op een vocaal uitgaande woorden als tembakos, djenakas en poelas. Bij de transcriptie van Koetaise woorden is in het algemeen voor deze klank het teken "s" gebezigd. Waar een in het handschrift of de editie met $k$ geschreven woord is besproken, en de uitspraak verder geen wijziging behoeft, kwam mij dit echter onnodig voor. Hierbij zij nog aangetekend, dat de eind- $k$ in Bandjarese woorden als $k$ (implosief) moet worden uitgesproken.

De in Bespr. 299 gestelde vraag, of spellingen als te(r)kedjoed, gelab en tiarab e.d. op de Koetaise uitspraak teruggaan, kan ik evenmin als destijds met zekerheid beantwoorden. Het is overigens bekend, dat ook in andere Maleise handschriften wel onderscheid, doch zelden konsekwent, wordt gemaakt tussen eind- $p$ en eind- $b$, en dat sommige zuiver Maleise woorden zelfs vrij constant met eind- $b$ worden geschreven, 
zoals bijvoorbeeld lembab. Evenmin als K. Wulff ${ }^{1}$ ) daartoe in staat was voor het Peraks kan ik in het Koetais een duidelijk onderscheid in de uitspraak van met $-p$ en $-b$ gespelde woorden waarnemen. Wel meent Wulff een klein onderscheid te horen in de eind- $d$ van Arabische leenwoorden en de eind- $t$ van echt Maleise woorden, hetgeen mij echter ook ontgaat. De moeilijkheid is gelegen in het feit, dat de dentale en labiale eind-occlusieven in het Koetais zowel als het Peraks, het Bandjarees (hier ook de gutturale) en waarschijnlijk eveneens de andere Maleise dialecten, implosieven zijn, waardoor eventueel verschil tussen media en tenuis voornamelijk uit een gering onderscheid in de uitspraak der voorafgaande klinkers zou moeten blijken. Een betrouwbare beslissing van deze kwestie is misschien slechts langs instrumentale weg te bereiken. Tegen het veronderstelde mediale karakter van de eindocclusieven in enkele woorden pleit in ieder geval het feit, dat zij bij afleiding met $-a n$ of $-i$ tenues zijn, schoon vaak als mediae geschreven. Dit is, naar men weet, zelfs het geval bij afleidingen van op een media eindigende Arabische woorden, zoals in kewadjiban, dat als kewadjipan wordt uitgesproken.

Zoals reeds boven is opgemerkt, is de spelling met alif voor pepet toe te schrijven aan Bandjarese afschrijvers of de invloed van Bandjarese spelgewoonten. Verder verraadt de vorm van sommige woorden, vooral in de afschriften van $\mathrm{N}$, ook anderszins Bandjarese invloed. (vgl. Bespr. 300 v.).

Volgens de mening van sommigen te Tenggarong is de teboekstelling der Salasilah te danken aan den door Tromp op bl. 67 zijner verhandeling als den enigen werkelijken kenner der kroniek geloofden Pangéran Sjarif Sokmawira, die haar gedicteerd zou hebben aan een Bandjarees. De historische onmogelijkheid hiervan wordt voldoende aangetoond door het feit, dat deze Pangéran een zoogbroeder van den in 1838 geboren Sultan Soelaiman was, terwijl, zoals wij zagen, het oudst gedateerde handschrift het jaartal 1832 draagt. Bovendien draagt onze archetypus $\mathrm{N}$ er alle sporen van een afschrift te zijn van een ouder, reeds op sommige plaatsen defect handschrift. Toch mogen wij deze overlevering niet geheel als waardeloos verwerpen, namelijk in zoverre, dat het zeer wel mogelijk is, dat de tekst door dicteren tot stand is gekomen. Hierin zou de verklaring gevonden kunnen worden voor het ontstaan van een typische wending, die in de Salasilah zo vaak voorkomt, dat men ze

1) Beobachtungen über die aussprache des malayischen im Sultanat Perak, Acta Orientalia IV, 269. 
bijna een stijlfiguur zou kunnen noemen. Ik heb hier het oog op de volkomen overbodige herhaling van het subject in de zin, zoals bijvoorbeeld in: maka laloe disoesoeinjalah anaknja itoe oléh Njaï Djaitan Lajar, maka iapoen menjoesoelah anaknja itoe (121/2, twee gevallen); maka boeihpoen sesaklah Mahakam oléh boeih itoe (125/15, met verandering van grammaticaal subject); maka iapoen sampailah ia ke Beroenai (145/27); maka iapoen sampailah adji itoe ke Sambas (152/8); maka tadjau itoe dinaikkanlah keatas balai tjandipoera tadjan itoe (185/32); maka segala orang mengadappoen boebarlah ia (227/17); maka Radja Mandarsahpoen rebahlah ia sakit (239/6). Zeer vreemd is wel: maka haripoen malamlah ia (173/18), wat waarschijnlijk wel een schrijffout is in verband met het daarop volgende: maka Meragoei doea laki binipoen bermalamlah ia. Het komt mij voor, dat deze figuur typisch is voor de verhalende stijl van iemand, die gedwongen is zijn verhaal ongewoon langzaam te doen, zoals bij dicteren het geval is. Men vergelijke de volgende zin uit de Hikajat Sri Rama van Maxwell, die immers ook op de mondelinge voordracht teruggaat: maka Kera Ketjikpoen beriang-ianglah ia kepada segala déweata ${ }^{1}$ ).

Een ander stijlelement van geheel verschillende aard en veel meer belang zijn de korte rhythmische passages, die soms in stereotype beschrijvingen met het proza afwisselen. Daar dergelijke passages in handschriften noch tekstuitgave door schrijfwijze of druk worden onderscheiden van de gewone prozagedeelten, zodat men er licht overheen leest, terwijl de herkenning van de vorm soms een hulpmiddel kan zijn om de tekst beter te begrijpen, moge dit verschijnsel hier enigszins uitvoerig worden besproken.

De langste rhythmische passage vindt men in de klaarblijkelijk traditionele woorden, gesproken door de twee partijen tijdens een vorstelijk huwelijksaanzoek op bl. 165. De vertegenwoordiger van den prins, voor wien het aanzoek wordt gedaan, spreekt tot de moeder van het meisje:

1) JSBRAS 17, 1887, bl. 69. In de ,romanised edition” van dit volksverhaal in hetzelfde tijdschrift $(55,1910$, bl. 86$)$ is ia evenals segala geschrapt. Misschien wel opzettelijk, want deze heruitgave bevat meer ,verbeteringen". Ofschoon Winstedt er zijn naam aan heeft gegeven, is het duidelijk, dat de transcriptie het ongecorrigeerd product is van een afschrijver, die zijn taak weinig ernstig heeft opgevat, getuige verschillende verkeerde transcripties en vele omissies van woorden en zelfs hele regels. Als authentieke taalbron kan daarom slechts de oude uitgave gebruikt worden. 
(kaoela njai) dititahkan oléh Déwa Adji disoeroeh oléh Déwa Ratoe hendak mengandoeng, hendak mengapang hendak bertedoeh dikajoe agoeng hendak berlindoeng dikajoe besar hendak berlindoeng kehoedjanan hendak bernaoeng kepanasan (djikanja seperti orang pandai) hendak menggantikan pisau ditangan hendak menggantikan pahat didjari (sekarang ini orang tiada tahoe) akan pendjerat tangga rentas akan pendjerat djamban hanjoet minta djala, djala benang minta djala, djala soetera minta djala, laloe boléh minta rénggé, laloe dapat.

Hierop antwoordt de moeder van het meisje:

(akoe ini) seperti lading penjangga darah lamanja kena, lamanja loeka seperti lantjang diboerit djamban lambatnja goegoer, lambatnja disambar (apa djoeakah akoe ini) tiap-tiap orang laki(-laki) berbini tiap-tiap orang bini berlaki.

En enige regels verder zegt degeen, die het aanzoek doet, vragend naar de verlangde bruidschat, nog:

kami minta goegoeri oetang kami minta goegoeri barih.

In twee bijna gelijkluidende beschrijvingen van de tandevijlingsceremonie (bl. 132 en 138) vinden wij de volgende passages :

a) pepangkon besar tinggal ditanah pepangkon renik naik kebalai. (138 diatas iplv. naik) 
b) (berboenjilah bedil dialoen-aloen) pasang tjetjorong dikota tjondong pasang meriam dirantjas soedji.

c) poepoeslah pendaoengan oléh si Loemadjang sampoenlah pendaoengan oléh si Loemakoe gigi sebintir dibelah waloe gigi sebilah dibantjar toedjoeh gigi lakoe menjirip lais doea belas goerindjam giginja berdjoentaian poentjak reboengnja. (samengesteld uit de lezingen van 132 en 138).

d) demi berlari air pinangnja demi beroendja-roendja air sirihnja.

. Uit deze voorbeelden zien wij, dat dergelijke stukken zich niet alleen door hun rhythme, doch tevens door parallellisme van het gewone proza onderscheiden. Dit is eveneens typerend voor de rhythmische gedeelten in de Maleise z.g. penglipoer-lara-verhalen, en voor de Minangkabause $k a b a$ en de Midden-Maleise andaj-andaj in hun geheel. Dezelfde kenmerken van deze oude Maleise verhaalvorm ${ }^{1}$ ) vindt men ook in de Koetaise verhalen, welke men pekenan noemt. In deze is het parallellisme zo sterk, dat men kan zeggen, dat zij geheel bestaan uit strofen van telkens twee regels, waarin met andere woorden hetzelfde of ongeveer hetzelfde wordt gezegd. De regels bestaan meestal uit vier, soms uit drie woorden, waarvan het gezamenlijke aantal lettergrepen normaliter varieert tussen acht en tien, wat echter, vooral bij lange namen en woordherhaling, wel eens belangrijk wordt overschreden.

Voor de parallelle uitdrukkingswijze heeft het Koetais een technische term, nl. taki; zich daarvan bedienen heet betaki. Een bijkomende eigenaardigheid van dit $t a k i$ is, dat een deel van de hierin gebruikte woorden niet tot de dagelijkse taal behoren. Door het gebruikmaken van verouderde en uit andere talen ontleende woorden, die in de spreektaal niet bekend zijn niet alleen, doch ook door het bezigen van gewone woorden in een, men mag wel zeggen willekeurig daaraan gegeven

1) Vgl. Dr. P. Voorhoeve, Uit de letterkunde van Zuid-Sumatra, Supplement op het Triwindoe-gedenkboek Mangkoe Nagoro VII, Soerakarta 1940, bl. 133, en Dr. C. Hooykaas, Over Maleische Literatuur, bl. 46 vv. en de daar geciteerde werken. 
betekenis, doet dit taki aan als een echte kunsttaal. En daar de belians en déwa's zich bij de uitoefening van hun functie van het taki bedienen, is het waarschijnlijk, dat wij er tevens de Koetaise ceremoniële of priestertaal in voor ons hebben.

Meer voorbeelden uit de Salasilah van de echte taki-stijl, in elk waarvan een of meer woorden voorkomen, die de spreektaal niet kent, zijn :

baoe tjekoer baoe balönja

baoe djeringau baoe toeboehnja (177/7, vgl. 128/21)

mangkin sehari mangkin besar

sin semalam sin langgoeng (129/9, vgl. 170/20)

mangkin sehari sin besar

mangkin sehari sin tjerdik $(128 / 29,177 / 11)$

demi semangka dibelabar

demi entimoen diboemboeni $(128 / 30,177 / 13)$

pasang bedil dipebajakan

egoeng-gendang dipetjaramkan (132/27, vgl. 139/10)

bersoerak bergantoeng diawan

beteri bergantoeng diméga (132/33)

Adjipoen mengantokkan érau

Adji menjoedahkan sawat $(132 / 26)$

mengarioek (mengerojok?) kerbau génggong

menjembelih banténg menamang $(134 / 18,135 / 7)$

djarikoe dipatoek tedoeng ari

pinggangkoe dibelit tedoeng boelan (161/8).

Zonder mij te begeven in een nader onderzoek naar het wezen van dit rhythme, waarbij het nog te weinig bestudeerde Maleise woordaccent blijkbaar, evenals dat in pantoen en sjacir het geval is, een veel belangrijker rol speelt dan het antal lettergrepen, wil ik hier nog enige rhythmische strofen uit de tekst aanhalen, welke zich niet van litteraire woorden bedienen: 
egoeng siang ditopéngkan

egoeng malam diwajangkan (134/31)

(baris orang ditanah pepangkon)

gandjoer pandjang bergembala merak

gandjoer p.nt.ng bergembala benang (136/18)

djebang demi soesoen sirih

perisai demi sisik tenggiling $(136 / 21)$

(maka) léman soedah terbentang

oelas boemi soedah terhampar (136/23)

laki-laki kandjar ditanah

bini-bini kandjar diroemah (132/20, vgl.139/5, 192/5/9)

laki-laki mengadang ditanah

bini-bini mengadang diroemah (177/1, vgl. 178/13)

orang laki bekerdja ditanah

orang bini bekerdja diroemah (183/15).

Hoe het rhythme van zulke vaste uitdrukkingen kan worden bedorven ziet men in de ontwikkeling van de strofe:

bedil demi peroempoeng toenoe egoeng-gendang demi katjang diaroe (128/5)

waarin de samenstelling (e)goeng-gendang als één woord kan worden opgevat. In 130/31 vinden wij:

egoeng-gendang demi katjang diaroe soeara bedil demi peroempoeng toenoe.

Hier bederft de toevoeging soeara de maat enigszins, evenals boenjinja op dezelfde plaats in 135/16. Maar deze uitdrukking past zo nog niet geheel in de hikajatstijl, die er van maakt (134/24): maka orangpoen memboenjikan bedil seperti peroempoeng toenoe, egoeng-gendang seperti katjang diaroe of (178/11) maka berboenjilah egoeng-gendang demi katjang diaroe, témbak bedil demi peroempoeng toenoe. Nog een stapje verder, een enkel voegwoord meer, en van het oorspronkelijke rhythme 
is niets meer over. In deze voorbeelden slaan wij als het ware de ontwikkeling, of liever achteruitgang, van de pittige, rhythmische uitdrukkingswijze tot de onbeholpen, slappe hikajatstijl in processu gade.

Ook door de invoeging van voegwoorden en partikels als lah en poen wordt het rhythme ongunstig beinvloed, als bijvoorbeeld in:

$$
\begin{aligned}
& \text { maka berléngganglah boemi ditidjaknja } \\
& \text { bergoentoerlah langit diseroedoekinja (131/25, vgl. }
\end{aligned}
$$

waar men behalve maka ook de beide lah's zou willen schrappen.

Het parallellisme in de behandelde uitdrukkingen is naast het veelvuldig ontbreken van de in prozastijl onmisbare voegwoorden en nadrukswijzers een zekere waarborg, dat zij niet toevallig rhythmisch zijn. Dit laatste zou wel het geval kunnen zijn met deze passage:

$$
\begin{aligned}
& \text { ada jang diakoenja anak } \\
& \text { ada jang diakoe tjoetjoe } \\
& \text { masing-masing dibekalinja } \\
& \text { ada jang diberinja talam } \\
& \text { ada jang diberinja senggan tembokang } \\
& \text { masing-masinglah dengan kadarnja (140/8). }
\end{aligned}
$$

Het gebruik van ada jang bepaalt reeds de parallelle uitdrukkingswijze, terwijl de structuur van het Maleis daarbij het rhythme als vanzelf met zich meebrengt.

Niet toevallig schijnt mij echter toe het, gedeeltelijk bedorven, rhythme in de beschrijving van het fabuleuze rijdier Lemboe Soeana:

\author{
bergading berbilalai roepanja seperti gadjah \\ bertaring seperti roepa matjan \\ bersirik (bersoerai ?) seperti roepa koeda \\ toeboehnja toeboeh koeda bersajap \\ bertadji seperti roepa goerda \\ berékor seperti roepa naga \\ bersisik sepandjang toeboehnja (126).
}

Tenslotte zij nog de aandacht gevestigd op de beschrijving van een vechthaan, die behalve rhythmisch ook rijmend is, en uitgezonderd wat betreft het aantal regels, de sjacir-vorm vertoont: 
boedjang landjoean rantjah kaki

berkokok bergentar boemi

edjoeng pérak kemoedi besi

sisiknja pérak koekoenja besi

disaboeng bertaroehkan diri (162)

en korter:

edjoeng pérak kemoedi besi

bersisik pérak bertadji besi

maka berkokok bergentar boemi (141/32).

Waar de teboeksteller van de Salasilah er niet wars van is geweest het proza met poëtische stukjes af te wisselen, zoals dat bij de mondelinge voordracht wel in nog sterkere mate gebruikelijk zal geweest zijn, kan men er zich over verbazen, dat men in het gehele werk geen pantoens ontmoet. Het is echter een merkwaardig feit, dat de pantoen bij de Koetainezen, voorzover mijn ervaring tenminste reikt, niet bekend is. Mocht ik mij hierin vergissen, en zou deze litteraire vorm toch in het Koetaise worden aangetroffen, zonder dat recente invloed van elders, met name van Bandjarezen, onder wie de pantoen zeer geliefd is, is aan te tonen, en misschien onder een andere naam, in ieder geval speelt zij toch niet die belangrijke rol in het sociale leven, die men haar elders ziet vervullen. Terwijl bijvoorbeeld in Bandjermasin bij het ouderwetse huwelijksaanzoek pantoens worden gebezigd, zien wij in de Salasilah hiervoor de taki-stijl gebruikt. Ook van de fixatie van adatregels in pantoens, zoals die elders wordt aangetroffen, is mij niets gebleken; ook in de Oendang-oendang Beradja Nanti, het Koetaise adatwetboek, komen geen pantoens voor.

\section{§ 4. Elementen van vreemde oorsprong in de Salasilah.}

Bij de lectuur van de Salasilah krijgt men de indruk, dat de „auteur” zich bij zijn weergave van de oorsprongsmythen der eerste Koetaise vorsten en de latere geschiedenis van het vorstenhuis grotendeels gehouden heeft aan wat de overlevering daarover vertelde. Van onmiddellijke ontlening uit de Maleise litteratuur van verhalen en legenden is dan ook volgens Dr. Mees, die hiernaar een onderzoek instelde, geen sprake. Anders is het gesteld met het gedeelte, dat handelt over de reis van Maharadja Soeltan met Maharadja Sakti en den Moearakamansen vorst Maharadja Indramoelia naar Madjapait, welke ten doel had ,om adat te gaan vragen". De lessen, die door den roemruchten Bermawidjaja en Patih Gadjah Mada (Meda volgens Koetaise uitspraak) aan 
de Borneose vorsten worden gegeven, verschillen in taal en stijl duidelijk van het hoofdverhaal, en. van twee gedeelten heeft men dan ook kunnen bewijzen, dat zij uit een ander Maleis werk zijn ontleend. Cense heeft er namelijk in zijn dissertatie (bl. 139, noot 2) op gewezen, dat de in $212 / 16-213 / 4$ en $217 / 1-219 / 34$ voorkomende onderwijzingen overgenomen zijn uit de bekende vorstenspiegel Tadjoessalatin of Makota segala radja-radja. De redactie van deze stukken in de Salasilah wijkt af van die van alle mij bekende uitgaven, doch staat dichter bij die der editie-Roorda van Eysinga (bl. 63 vv. en 139 vv.) dan die van de Bataviase uitgave van 1864. In de uitgave van Van Dorp (Semarang 1866, vgl. Brandes, TBG 38, bl. 272) komen de bedoelde passages in het geheel niet voor. Afgezien van kennelijke fouten in de kroniek betreffen de verschillen somtijds slechts de taal en het woordgebruik, waarbij het opvalt, dat de Salasilah meermalen natuurlijker Maleis geeft dan zijn vroeger om zijn taal ten onrechte zo hoog geroemde voorbeeld, doch somtijds drukt de Kroniek zich geheel anders uit. In hoeverre deze verschillen zijn toe te schrijven aan de persoon, die de passages in de kroniek verwerkte of inlaste en de afschrijvers van het werk, is niet met zekerheid te zeggen, daar wij niet weten, of niet soms gebruik is gemaakt van een ons onbekende, van de editie-Roorda van Eysinga afwijkende tekst. Het is echter wel waarschijnlijk, dat de inlasser bij het overnemen enkele wijzigingen doelbewust heeft aangebracht, en van één soort van dergelijke veranderingen kan dit wel met zekerheid worden gezegd. Ik heb hier het oog op het feit, dat overal, waar in de Tadjoessalatin sprake is van Allah, de kroniek zijn vermelding vermijdt of er iets anders voor in de plaats stelt. Zo vervangt hij hamba Allah door racjat (212/18), hakk soebhānahoe watacālä door hati jang baik (219/17), Toehan sarwa sekalian calam door radjanja (217/4) en dergelijke meer. Geheel in overeenstemming met deze heidense houding wordt het woord sjarīcat door cadat vervangen $(217 / 26 / 29)$ en atas segala perempoean fardoe menoetoep sekalian toeboehnja van zijn te sterk islamitische tint ontdaan door het weer te geven met atas segala perempoean tiada patoet dilihat toeboehnja (213/34). Degeen, die de betrokken passages inlaste, was er zich dus wèl van bewust, dat de vermelding van Allah en alles, wat al te duidelijk des Islams was, niet in dit zich nog in voor-Mohammedaanse tijd afspelende gedeelte der kroniek paste ${ }^{1}$ ). Verschillende andere af wijkingen

1) In dit opzicht onderscheidt zich trouwens de gehele kroniek gunstig van sommige andere Maleise historische werken. In de Salasilah wordt nooit ook maar de minste moeite gedaan het heidense karakter der meegedeelde oorsprongs- 
berusten op misverstaan van de oorspronkelijke tekst. Voor verdere bijzonderheden zij verwezen naar de aantekeningen, waar de afwijkingen van de editie-Roorda van Eysinga (,vE”) zijn gesignaleerd, voorzover de tekst der Salasilah verbetering of verduidelijking behoeft of de verschillen van enig belang schijnen.

Andere gedeelten zijn volgens Cense t.a.p. aan de Javaanse zedekundige litteratuur ontleend. Hij wijst op de verwantschap van de passage, die handelt over de vijf personen aan wie men een sembah verschuldigd is (214/29-215/22), met een passage in de Woelang Rèh, waar een opsomming van dergelijke aard wordt aangetroffen. De woorden van Dr. Mees, als zou de opsomming in de Salasilah ,zijn voorbeeld" vinden in de Woelang Rèh, zijn natuurlijk minder gelukkig gekozen. De onmiddellijke bron van dit gedeelte is nog niet terecht gebracht, evenmin als van de volgende, naar taal en inhoud te oordelen eveneens ontleende passages:

207/33-208/4 : Vier soorten van soeaka.

208/5-21 : Vorstin in plaats van vorst, contact tussen ministers en vorstin.

208/23-32 : De zoon van de permaisoeri is troonopvolger.

208/34-209/10: Wat de pakaian (in figuurlijke zin) van den radja is. (zie ook de commentaar).

209/14-26 : Gevallen waarin de vorst iemand ter dood mag laten brengen.

209/27-210/1 : Waarvoor de vorst moet waken.

210/1-8 : Vijf soorten van soeaka.

210/9-18 : In welke gevallen een ter dood veroordeelde zijn leven kan redden door naar de kraton te vluchten.

213/6-26 : Wie troonopvolger is, als de permaisoeri geen zoon heeft en over de titels der gemalinnen van den vorst en van boepati's.

mythen te verbloemen of deze, door er bijvoorbeeld bekende namen uit de voorgeschiedenis van de Islam in te betrekken, enigermate te sanctionneren. Men schijnt daaraan in Koetai geen behoefte te hebben gevoeld. Evenmin heeft men tot op heden getracht het jaarlijkse hof-érau, dat bestaat uit een aaneenschakeling van religieuze ceremoniën, ook maar enigermate aan het Mohammedaanse geloof aan te passen, behalve dan dat tot besluit de onvermijdelijke doca selamat wordt gereciteerd. Juist aan de zuiverheid der mythen, niet merkbaar beinvloed door Islam of Hindoe-Javaanse mythologie, en de nauwe samenhang van een nog steeds in ere gehouden ritueel met sommige dezer mythen ontleent de Salasilah haar grootste bekoring. 
219/34-221/11: Verdere plichten van den menteri. Dit gedeelte sluit onmiddellijk op een aan de Tadjoessalatin ontleend stuk aan. Ook in stijl komt het hiermee overeen.

221/16-222/31: Over soeaka en hoe men zich gedragen moet als men voor den vorst verschijnt (hofetiquette).

De meeste dezer passages zijn min of meer corrupt, terwijl men naar analogie van wat de uit de Tadjoessalatin overgenomen stukken te zien geven, mag aannemen, dat de ,auteur" der Salasilah opzettelijk tamelijk ingrijpende veranderingen heeft aangebracht. Pogingen om de tekst van dergelijke gedeelten bij conjectuur te herstellen zonder kennis van het origineel zijn dan ook tamelijk gewaagd.

In het vlak aan de Javaanse reis voorafgaande gedeelte schijnt mij ook ontleend 190/17-191/6 over de vier eigenschappen, namelijk van oude lieden, krankzinnigen, vrouwen en kinderen, terwijl tenslotte ook $186 / 21-188 / 21$, waarin vier vorstenzonen, die ieder slechts op één bijzondere eigenschap kunnen bogen, hun jongsten broeder, die alle vier eigenschappen in zich verenigt, als den geschiksten opvolger van hun overleden vader aanwijzen, afkomst van elders verraadt.

Om het beeld van de litteraire kennis van den auteur te voltooien worde hier nog terloops de aandacht gevestigd op zijn bekendheid met de verhalen van Boma en Damar Woelan, welke blijkt uit de vermelding der namen van enkele hoofdfiguren daaruit (zie de aantekening bij $159 / 32$ en $160 / 2)$.

Anders dan met de boven besproken ontleningen staat het met bepaalde stereotype beschrijvingen, zoals van de galakleding der Koetaise vorsten, die in hoofdzaak Javaanse termen bevatten. Ik wees er vroeger reeds op (Bespr. 311), dat men voorzichtig moest zijn om met Cense (Dissertatie 129) aan te nemen, dat deze stukken aan Maleise Pandjiverhalen ontleend zouden zijn, o.a. omdat men dezelfde beschrijvingen ook in de Javaanse wajang-litteratuur aantrof. Waar de Salasilah, voorzover mij is gebleken, weinig of geen specifieke tekenen van de invloed van Pandjiverhalen vertoont, maar daarentegen allerlei uitdrukkingen bevat, die in de wajangsfeer thuis behoren, doet men beter aan te nemen, dat dit laatste ook met de beschrijving der vorstelijke tooi het geval is, daarbij tevens in het oog houdende, dat zij voor een deel overeenkomen met wat de werkelijkheid aan het Koetaise hof te zien gaf en nog geeft. Men behoeft bij deze invloed van wajanglitteratuur niet aan onmiddellijke ontlening aan de een of andere lakon te denken. Men stelle zich eerder den auteur voor als iemand, die van 
de lakonstijl op de hoogte was, misschien zelf als dalang kon optreden, net als enkelen der thans levende pangérans, en die zich in zijn verhaal daarom van tijd tot tijd van stereotype wajangtermen kon bedienen. Iedere Tenggarongse dalang heeft evenals zijn Bandjarese collega's een aantal vaste, in elke lakon bruikbare Javaanse passages en uitdrukkingen in min of meer verbasterde vorm tot zijn beschikking. Uitdrukkingen als poetera batara, akadang dérca, widjiling tapa, rembesing madoe, toesing kesoema (119/20 en elders), en sedakap (a)soekoe toenggal, anoetoepi babahan sòngò, angambah djemantara (160/26) schudt de auteur uit zijn mouw, maar ook de stereotype welkomstgroet $(201 / 27$ vv.) en het verliefde gemurmel van den vorst van Madjapait $(215 / 26)$ geeft hij in het Javaans weer. Zuiver lakonstijl is ook: amaténi pòntjò-driò, pòntjò : li(l)ma, driò : angan-angan (Jav. amatèni påntjădriå, påntjå : (li)limå, driå: angen-angen) (195/34 v.). Ook het blijkbaar nogal corrupte verhaal over de luchtreis op bl. 196 schijnt niet vrij van lakoninvloed te zijn.

De onregelmatigheid in de spelling (uitspraak) van de $a$ van Javaanse woorden, die de Salasilah behalve in de bovenstaande voorbeelden ook elders meermalen te zien geeft, kan men precies zo bij Bandjarese dalangs waarnemen. Van de regels, die de $\dot{a}$-uitspraak bepalen, zijn zij namelijk niet al te goed op de hoogte, zodat zij zich vaak bezondigen aan fouten en inconsequenties als het binatòrònò (jav. binåtå-rånå) van $198 / 6$ en oedò nagòrò, naast oedò negara en oedò negarò (zie aantekening bij 212/11).

Te Tenggarong kan men het streven opmerken om woorden van Javaanse herkomst, of die daarvoor gehouden worden, ook op zijn Javaans uit te spreken. Het woord kenaka bijvoorbeeld, dat hier een speciale betekenis heeft, wordt thans kenòkò uitgesproken. Ook zegt men gewoonlijk petolò, welke uitspraak klaarblijkelijk reeds in Tromp's tijd de gebruikelijke was (Tromp aant. 176), hoewel de Salasilah petola spelt. Antakesoema wordt thans òntrò-kesoemò uitgesproken enz. Dezelfde neiging kan bij afschrijvers van de Salasilah bestaan hebben. Daarom kan men bezwaarlijk aan het al of niet aangegeven zijn der

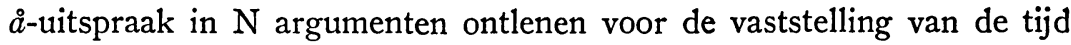
der overname of de streek van herkomst van bepaalde Javaanse woorden of passages.

Enkele Javaanse woorden in de Salasilah vertonen reduplicatie (bebekal, beboréh, - naast boréh -, dedoekoen, lelakon, memorong, pepangkon naast pangkon - aangenomen wordt, dat de twee laatste woorden inderdaad van Javaanse origine zijn —, pepandén, sesaté naast 
saté), waar het huidige Koetais, voorzover zij bekend zijn en met uitzondering van memorong, de ongeredupliceerde vorm heeft: boréh, doekoen, lakon, pangkon, pandén, saté. Dergelijke reduplicatie, die de betekenis van het woord in genen dele beinvloedt, treft men in oudere Javaanse litteratuur veel aan, terwijl ook vele Javaanse leenwoorden in het Balinees en het Madoerees haar vertonen. Dit laatste zal wel aan de invloed van Oost-Javaanse pasisirdialecten mogen worden toegeschreven, en vermoedelijk geldt dit ook voor de vorm der Javaanse leenwoorden in het Koetais. Ook een uitspraak als Kentjana Oengoe (159/32) voor Solonees Kantjana Woengoe kan op Oost-Javaanse herkomst wijzen, al is een dergelijke uitspraak, naar Pigeaud mij meedeelt, algemeen pasisir.

Het verdwijnen van de reduplicatie, indien zij tenminste ooit in de spreektaal is voorgekomen en niet tot de litteratuur beperkt is gebleven. behoeft niet onmiddellijk aan modern-Javaanse invloed te worden toegeschreven, hoewel deze in het bijzonder in woorden, die met de wajang in verband staan, meegewerkt kan hebben. De neiging tot „ontreduplicering" blijkt immers ook in het Koetais zelf werkzaam te zijn geweest. Men vergelijke koet. djala, venster, dat blijkens de Salasilah eens djala-djala geluid heeft, en dat waarschijnlijk via djedjala, welke vorm nog in een Basaps dialect wordt aangetroffen, zijn huidige vorm heeft gekregen. Evenzo is koet. kana', kind, ontstaan uit kanas$k a n a^{s}, k e k a n a^{s}$. Reduplicatie is dan ook in het tegenwoordige Koetais geen gewoon verschijnsel, in tegenstelling tot het Bandjarees, waar zij in plaats van of naast woordherhaling veelvuldig optreedt, en verder o.a. dient tot de vorming van nomina instrumenti. In dit dialect hebben vele Javaanse leenwoorden nog steeds een geredupliceerde vorm, bijvoorbeeld baboréh, dadoekoen, lalakon, dadalang, kakaloeng, kakamban (jav. kemben), enz.

Het zal duidelijk zijn, dat een groot deel der Javaanse woorden in de Salasilah niet als in het Maleis van Koetai overgegane leenwoorden mogen worden beschouwd. Dit geldt in het bijzonder voor die, welke voorkomen in de beschrijving der inrichting van de kraton en de hofhouding van het zogenaamde Madjapait, en de aldaar in zwang zijnde gebruiken. Met deze gedeelten heeft de huidige bewoner van Tenggarong, zelfs wanneer hij in letterlijke zin is ",nourri dans le sérail”, dan ook bijna evenveel moeite als ieder ander van het Javaans onkundige of niet met een behoorlijk Javaans woordenboek gewapende lezer der Kroniek. Vermoedelijk zijn de bedoelde beschrijvingen niet aan de litteratuur ontleend, doch berusten zij op eigen aanschouwing van een 
Javaans hof bij den auteur, c.q. interpolator, zelf of een zijner zegslieden. Misschien nam hij ze op als een voorbeeld ter navolging door het Koetaise sultanshof, misschien was ook de zucht om zijn kennis te luchten of om het verhaal door overgieting met deze Javaanse saus een échte smaak te geven, zijn drijfveer. Het is wel aardig hierbij op te merken, hoe ook in andere gedeelten der Salasilah, die in het buitenland spelen, enkele plaatselijke, niet-Koetaise woorden zijn gebruikt, waardoor een lichte couleur locale wordt verkregen (vgl. aant. bij 150/13 Broenais, en 173/17, 176/33 Basaps).

Er kan niet genoeg de nadruk op worden gelegd, dat de beschrijving der instellingen en gebruiken aan het Madjapaitse hof, alsook de adatlessen, die daar aan de Koetaise vorsten zouden zijn gegeven, door den Koetaier niet alleen om de taal, doch evenzeer om de inhoud, grotendeels als uitheems en oneigen gevoeld worden. Het lijkt er niet naar, dat ,die instellingen, na in de kroniek gecodificeerd te zijn, inderdaad een wezenlik bestanddeel van het hofceremonieel geworden" zouden zijn, zoals Dr. Mees op bl. 27 beweert, werkelijk doelend op het onderhavige gedeelte van de tekst blijkens de woorden, die hij er op laat volgen: „In de kroniek van Koetai wordt uitvoerig deze adat beschreven, die ontleend zou zijn aan het hof van Madjapahit." In werkelijkheid moet men in het omstandige verhaal van de Javaanse reis naar Koetaise, of ook maar alleen aan het hof te Tenggarong gerecipieerde; adatelementen met een lantaarntje zoeken. Interessant is dit gedeelte der Salasilah dan ook voornamelijk slechts om het feit der ontlening uit vreemde, niet-Koetaise bronnen, en de wijze, waarop ze is toegepast en in een oude legende is verwerkt, doch omtrent het wezen en de omvang van de invloed van de Javaanse of andere uitheemse cultuur in Koetai openbaart het ons bitter weinig, omdat er bijna geen Koetaise elementen in zijn verwerkt. Voor de kennis van de Koetaise hofadat moet men dan ook elders in het werk zoeken, en wel bij beschrijvingen van érau-, tidjak-tanah-, menoeroenkan ketepian-, tepoeng-tarear- en dergelijk ceremonieel.

\section{§ 5. Een korte versie van de Salasilah.}

Als bijlage is een transcriptie afgedrukt van een korte versie der Kroniek, die mij de dag voor mijn vertrek uit Tenggarong in handen kwam. Zij is tijdens de regering van Sultan Soelaiman (1850-1899) geschreven door een inwoner van Kampoeng Pandji en bevat een kort verhaal van de geschiedenis der eerste drie vorsten van Koetai, gevolgd 
door een hier niet afgedrukte opsomming van de volgende sultans, die nogal afwijkt van die in de Salasilah, en parallel daaraan een lijst van de afstammelingen van Maharadja Sakti, waarom het blijkbaar in de eerste plaats te doen is geweest. Onder hen wordt een zekere Awang Lambang genoemd, die volgens verkregen inlichtingen de schrijver van het stuk is.

Degeen, die mij het geschriftje leende, verzocht mij, indien ik het volgens hem waardeloze verhaal toch wilde publiceren, met nadruk te vermelden, dat de inhoud niet mocht gelden als de door de bewoners van Kampoeng Pandji erkende overlevering. Deze wijkt immers op verschillende punten af van die der Kroniek, welke als de authentieke geschiedenis van het Koetaise vorstenhuis wordt beschouwd. Bovendien valt de schildering van een lid van dit huis, Maharadja Soeltan, en zijn verhouding tot zijn ouderen broeder en minister, Maharadja Sakti, zeer in het nadeel van eerstgenoemde uit. Hij wordt voorgesteld als een onbeduidend en koppig vorst, terwijl zijn wijze en actieve broeder de held van het verhaal is. Het is begrijpelijk, dat men deze partijdigheid, verband houdend met plaatselijk chauvinisme - Maharadja Sakti is immers de stamvader der inwoners van Kampoeng Pandji - enigszins choquant vindt.

Dit neemt niet weg, dat deze in stuntelige stijl gestelde korte geschiedenis voor de kennis der volksoverlevering, want de schrijver zal toch daaruit geput hebben en het verhaal niet uit zijn duim gezogen hebben, nog wel van enig belang is, en dat zij hier en daar ook bijdraagt tot een beter begrip van de Salasilah.

Het eerste gedeelte kan beschouwd worden als een korte, in hoofdzaken met de door de Salasilah gegeven voorstelling overeenkomende weergave van de voornaamste feiten uit de geschiedenis van de twee eerste Koetaise vorstenparen. De tweede helft, die gewijd is aan de geschiedenis van Maharadja Soeltan, vertoont belangrijker afwijkingen. De voornaamste hiervan is wel, dat de islamisering volgens dit verhaal tijdens Maharadja Soeltan's regering valt, nadat deze van zijn bezoek aan den vorst van Madjapait was teruggekeerd! Evenals in de Salasilah Maharadja Makota wil hier Maharadja Soeltan zich slechts voor het nieuwe geloof laten winnen, nadat zijn toverkunst het tweemaal tegen die van Toean Toenggang Parangan heeft moeten afleggen. De laatste toont zijn meerderheid eerst doordat zijn schoen, tegelijkertijd met 's vorsten kroon omhoog geworpen, op deze neerkomt. Vervolgens overwint hij den vorst in een wedstrijd in het verstoppen, waarbij hij zich in Maharadja Soeltan's eigen buik onvindbaar maakt. 
Maharadja Sakti's grote gaven worden in dit stuk o.a. gedemonstreerd doordat hij op verzoek van „Ratoe Maharadja Pait” den onoverwinlijken Tioeng Mendoro (Jav. Sioeng Wanara), die 's vorsten vader Djoko Toendoeran (Jav. Djaka Tandoeran) had gedood, verslaat.

Niet oninteressant is de voorstelling, dat Maharadja Pait zijn bezoekers als adatbron de Oendang-oendang Beradja Nanti en de „Oendang-oendang Pandji Salatin" medegeeft, respective bestemd voor Maharadja Sakti en zijn nakomelingen en Maharadja Soeltan en de zijne. Deze opmerking immers maakt het waarschijnlijk, dat de Tadjoessalatin (van deze naam is Pandji Salatin natuurlijk een verbastering), de bekende vorstenspiegel waaruit, zoals wij gezien hebben, verschillende voorschriften in de Salasilah zijn overgenomen zonder dat de bron genoemd wordt, in Koetai als een soort van wetboek werd beschouwd en geraadpleegd. Om nader te onderzoeken wat hiervan nog bekend is, heeft mij de gelegenheid helaas ontbroken.

Op enkele afwijkingen van minder belang is in de aantekeningen de aandacht gevestigd. Deze aantekeningen bevatten ook de verklaring van enkele Koetaise woorden, die niet in de Salasilah voorkomen. Een deel der noten beoogt slechts het naslaan van verwijzingen naar deze tekst in de commentaar te vergemakkelijken.

Met betrekking tot taal en stijl is van dit stuk niet veel loffelijks te zeggen, al geeft het met zijn dikwijls wonderlijk gebruik van bepaalde stopwoorden en dergelijke wel een goed beeld van de kwazie-litteraire stijl van den gewonen man. De spelling is onregelmatig en soms Bandjariserend. Uitgezonderd de meermalen voorkomende spelling van de pepet met alif heb ik haar in de uitgave zoveel mogelijk gevolgd. Voor het gemak van den lezer is interpunctie aangebracht. Wat m.i. moet vervallen is aangegeven door vierkante haken, wat moet worden toegevoegd door gewone haakjes.

\section{§ 6. De Sedjarah Noesentara.}

In de loop van het jaar 1931 begon de toenmalige Boekhandel en Drukkerij „Keramat” te Samarinda de uitgave in afleveringen van een „Sedjarah Noesentara Keradjaan Koetai Karta Negara”. Deze uitgave is, naar ik uit betrouwbare bron heb vernomen, nooit voltooid, en waarschijnlijk zijn de zes deeltjes, die mij bekend zijn (uitgekomen op 21 Maart, 15 April, 1 en 15 October en 1 en 15 November van genoemd jaar), tesamen beslaand 193 bladzijden, de enige, die verschenen zijn.

Daar in dit geschrift een gedeelte der. stof van de Salasilah wordt 
behandeld, en het vermoedelijk door sommigen in Koetai thans als geschiedbron wordt gebezigd, wat ten gevolge kan hebben, dat hieraan ontleende verhalen weer aan belangstellenden als authentieke legenden worden opgedist, is het goed het hier even nader te beschouwen. Het is anoniem verschenen, doch is van de hand van wijlen Anang Atjil (Kesoemo Wiro Negoro), den Bandjaresen eigenaar van genoemde drukkerij, die van zijn historische belangstelling reeds had blijkgegeven door de uitgave van een „Lamboeng Mangkoerat, atau Sedjarah Radja Bandjar", eveneens in afleveringen bij dezelfde drukkerij verschenen (1930-1931). Dit laatste geschrift is een vrije omwerking van de in de Kroniek van Bandjermasin vervatte gegevens tot een verhaal in modern-Maleise stijl, enigszins in romanvorm. Klaarblijkelijk is de Sedjarah Noesentara bedoeld als een dergelijke omwerking van de Kroniek van Koetai. De schrijver heeft echter geen handschrift hiervan in handen gehad, noemt dit werk dan ook niet, doch heeft zijn licht opgestoken bij verschillende oude lieden, die hem de verhalen hebben meegedeeld, zoals zij dit weer van ouderen hadden gehoord, naar hij op bl. 33 meedeelt. Het is intussen duidelijk, dat hij niet alleen heeft gerefereerd aan de mondelinge overlevering, doch ook aan de uitgave van Tromp, speciaal voor de geboortegeschiedenis van Adji Batara Agoeng Déwa Sakti. Dit blijkt uit de opvallende overeenkomst van juist dit gedeelte van zijn verhaal met de tekst der Salasilah en enige misbaksels van woorden, die alleen bij Tromp, en zeker niet in de mondelinge overlevering konden worden aangetroffen (peri siantan, Jang-Jong e.d.). Verder zijn er verschillende aanwijzingen voor, dat de schrijver in de door hem gehoorde verhalen vele, soms ingrijpende veranderingen heeft aangebracht. Hierdoor is deze versie, die aanvangt met de geboorte van Poeteri Djoendjoeng Boejah om eerst daarna de geboorte van Batara Agoeng Déwa Sakti te vermelden, bezwaarlijk te gebruiken als een bron voor onze kennis van de volksoverlevering, en dus voor de wetenschappelijke bestudering van de Salasilah practisch waardeloos.

Rest nog te vermelden, dat het eigenlijke verhaal eerst begint in de tweede aflevering, op bl. 41. Het voorgaande is ingenomen door levensbeschrijvingen van den Sultan en de toenmalige landsgroten van Koetai. 


\section{COMM ENT A A R}

\section{8}

3 soeatoe kalakian, 21, 121/24, 172/27 id.; kalakian wordt door den schrijver klaarblijkelijk als een fraai syn. van kala opgevat. $\mathrm{N}$ spelt behalve op de laatste plaats overal كسكين. - N seorang orang Baboe Djaroema, in de volksmond hoort men vaak Baboe Djeloema, zoals ook in KV 9 en Sedj. Noesentara $42 \mathrm{vv.} \mathrm{Baboe} \mathrm{heeft} \mathrm{in} \mathrm{deze}$ tekst steeds de betekenis "moeder", als in litt. jav., en staat tegenover mama, vader (118/30,137/3/14 en pass.). $215 / 3$ staat het in een uit een jav. bron afkomstige passage als syn. van iboe (r. 7) tegenover $b a p a^{s}$. Met honorifiek suffix 236/24 babocanda naast $186 / 1$ en $236 / 34$ boenda. Dat baboe hier niet bepaald ,vorstelijke moeder” betekent, zoals volgens vdW in het br. het geval zou zijn, blijkt voldoende uit 167/15 baboe inang dan baboe pengasoeh, waarmee men mal. mas inang vergelijke. Blijkbaar is het een litt. woord: huidig koet. heeft $e m e^{s}$ of $m e^{s}$. Ofschoon 121/15 vv. wordt gesproken van de kinderloosheid van Baboe Djaroema, treedt 162/26/28 het meisje Djaroema op aan wie zij haar naam ontleent. -4 berpendoesoenan wordt hier als syn. gebruikt van berdoesoen, 121/22. Onder doesoen verstaat men gemeenlijk een kleine, vaste nederzetting buiten de eigenlijke kampong, temidden van vruchtenaanplant en bouwveld. Pendoesoenan werd mij verklaard als ,de plaats, waar men een vruchtenaanplant of bouwveld heeft, en waar men alleen tijdelijk woont." Klinkert geeft de vormen $p e(n)$ doesoenan in de bet. ,het land in tegenoverstelling met de stad." - Melanti, moet evenals de andere negeri's, die op deze bladzijde genoemd worden: Djaitan Lajar, Oeloe Doesoen, Sembaran en Binaloe, in de onmiddellijke nabijheid van het tegenwoordige Koetai Lama gelegen hebben. Deze negeri's, d.i. kampongs, „landschappen” te noemen, gelijk Tromp op bl. 5 doet, is te veel eer. - $6 \mathrm{~N}$ masing - poeloeh, lees met $\mathrm{T}$ boeah. - $9 \mathrm{~N}$ basorang iplv. berorang - Djaitan Lajar, zie aant. r. 4. 10 Hoeloe Doesoen, $\mathrm{N}$ hier en overal elders Oeloe D., naar koet. uitspraak. Zie aant. r. 4. - Sembaran, zie aant. r. 4. $-11 \mathrm{~N}$ dan ontbr. - Binaloe, gewoonlijk gespeld Benaloe (bv. 133/26 N), zie aant. r. 4. - 
$12 \mathrm{~N}$ heeft na radja een op een angka $r$ gelijkende krabbel, vandaar Tnt. 4. - 15 petinggi, tot op heden in Koetai gebruikelijk voor „kamponghoofd" (jav.). - Goenoeng Djaitan Lajar, een heuvel vlak achter Koetai Lama. - 19 memoedja berata betekent volgens Wilkinson in de mal. litt. afgodsbeelden vereren, waarbij wordt aangenomen, dat berata, dat buiten deze uitdrukking niet voorkomt, synoniem van berhala is. Echter wordt noch in de Salasilah, noch in de bdj.-mal. litteratuur, waar de uitdrukking vaak voorkomt, in dit verband verder van afgodsbeelden gerept. Het woord moet dan ook worden afgeleid van jav. poedja-brata, een fraaie uitdrukking voor poedja, godsdienstige verering (vgl. jav. tarak-brata $=t a r a k$ ). Brata is eigenlijk het inachtnemen van bepaalde observanties om een bijzonder doel te bereiken (voor de koet. bet. van berata zie aant. 186/6). Het komt mij voor, dat memoedja berata in de genoemde litteratuur ook meer hierop slaat dan op werkelijke verering van goden of andere hogere wezens. Trouwens, memoedja betekent ook in het mal. niet zozeer „vereren”, als wel bewerken met toverkrachtige formulieren, bijvoorbeeld een voorwerp, dat men in iets anders wil veranderen, of een godheid om hem op te roepen (vgl. Wilkinson's definitie). Zo heet ook het met heilige formulieren bezingen van de ledematen van den Sultan van Koetai bij de pelasceremonie, waardoor zijn lichaam als het ware opnieuw geformeerd wordt, moedja (vgl. aant. 126/6). Tenslotte treedt memoedja soms op als synoniem van mentjita, zijn gedachten concentreren op iets (vgl. ook atj. wdb.). - kepada tiap-tiap hari; kepada voor een juister pada is in deze tekst zeer algemeen, niet alleen bij tijdsbepalingen (vgl. Gerth van Wijk, Spraakleer 3, § 419), maar ook in uitdrukkingen als : kepada rasa hatinja, kepada pikirkoe, kepada penglihat kakanda, ada kepada, tinggal kepada (120/13, 172/14, 186/30, 187/28, 205/19, 208/3). Hetzelfde gebruik wordt aangetroffen in mal. teksten uit Bandjar, waar kepada in de spreektaal even onbekend is als in Koetai. - 22 segera, $\mathrm{N}$ spelt steeds sigera, ook de constante schrijfwijze in bdj. teksten. $26 \mathrm{~N}$ als Tnt. $7-30$ poela; $\mathrm{N}$ schrijft gewoonlijk poelak of poelas, evenals B (vgl. Mees bl. 115). De vorm poelang, die in B herhaaldelijk voorkomt (vgl. Mees ib., en 184, Bnt. 3) is bdj. en wordt bij uitzondering ook in $\mathrm{N}$ aangetroffen (o.a. 155/33). In de Hikajat Seri Rama (ed. Shellabear) vindt men het woord in dezelfde betekenis (19/8, 45/1, $47 / 18$ en pass.). - samboet mati baboe, tiada disamboet mati mama, vgl. Tromp aant. 61 . Het sterven van vader of moeder als onontkoombaar alternatief is een zeer verbreide spreekwoordelijke uitdrukking om de toestand aan te duiden van iemand, die zich voor een moeilijk 
dilemma geplaatst ziet. Men vergelijke o.a. Hik. Sri Rama Maxw. 23/19: djika tidak disembahkan mati iboe dan hendak disembahkan mati bapa (zie ook ib. 50/17); min. bas makan boeah simalakamo, dimakan bapas mati, indas dimakan iboe mati, verklaard met „serba salah, tiada dapat mengélakkan ketjelakaan" (Kamoes sv. malakamo) en ng. ladjoe matei bapa, oendoer matei indoe, melai matei biti (o.a. bij Grabowsky, Bijdr. 38, 1889, bl. 148). In KV 4 is de onderhavige uitdrukking verbasterd tot samboet, djikalan disamboet mati toeha, djikalau tiada disamboet mati moeda! - 31 mama is in de tekst het gewone woord voor vader, corresponderend met baboe, moeder (vgl. 137/3, $163 / 33$ en pass.). Met honorifiek suffix: mamanda, 185/34, 235/13 en pass. VdW geeft, vermoedelijk op grond van Tromp's aant. 62, mama als koet.; de huidige vorm is echter $e m a^{s}$ of $m a^{s}$ (vgl. 120, Tnt. 4). -33 loemoes, Tromp aant. 63 ,allen”. De grondbetekenis van koet. loemoes is ,habis sama sekali”, evenals in het bdj., ook in de zin van: geheel en al op, volkomen versleten van kleren en gebruiksvoorwerpen, vgl. ng. lomos. - 34 djala-djala; de verdubbeling is in Tenggarong niet bekend. Koet. djala heeft de bet. venster, oorspronkelijk van bamboelatjes vervaardigd en naar buiten opwaarts openklappend, welke bet. hier en 153/16 goed past. Tromp vertaalt in aant. 65 ,een soort gordijn", doch deze bet. is geheel onbekend. Voor het djala-djala van $165 / 9$ v. zie aant. aldaar. Het is mogelijk, dat djala in de zin van venster oorspronkelijk djala-djala heeft geluid, eigenlijk „netwerk, rasterwerk”, in verband met de boven beschreven vorm van het venster. Dit vermoeden wordt versterkt door bp. (Kerajaan) djedjala, vensteropening.

\section{9}

3 gantian houd ik voor een verbasterde schrijfwijze van een niet meer begrepen $g e n i$, welk jav. woord in de bdj. litteratuur een veel voorkomend syn. van api is. Vgl. bovendien $255 / 27$ seperti api bernjala-njala. 10 raga emas, van dit wondervoorwerp wordt in de kraton een gouden model, ter grootte van een walnoot ongeveer, bewaard. Bij het pelas hangt het aan de tali djoeita tegen de sangkoh piatoe. - 12 djabang. baji, jav. pasgeboren kind. - $13 \mathrm{~N}$ tangannja iplv. tangan. - 14 kalang sirah, hoofdkussen van een voornaam persoon (vgl. Tromp vert. en aant. 69), blijkbaar hoog voor kalang oeloe, dat in het huidige koet. kelngoeroe wordt uitgesproken, doch dat men nog onveranderd terugvindt in min. en boek. (als een oud, en wel oorspronkelijk bdj. woord voor bantal) en tob. halang oeloe (vgl. jav. karangoeloe). Het jav. woord sirah, dat ook in 't bdj. een hoog woord voor kepala is, is in 't koet. 
niet meer als zodanig bekend. - 19 awak, door $\mathrm{N}$ steeds awas gespeld, is koet. pron. pers. 2e pers. gemeenzaam $=$ mal. engkau, waarmee het in deze tekst dan ook afwisselt, bv. 125/26, 137/8 en pass. Vgl. de woordenboeken. - 20 kedang, lees kadang, 120/7 en pass. id., jav. verwant. N geeft gewoonlijk akadang (176/14, 182/6, 196/3, 203/3) met jav. pref. a-. Vgl. koet. koela kadang, bloedverwant, familie, bdj. kadang warga, id. - widjiling (sp. N) tapa, 176/14 en pass. id., jav. „vrucht der boete", evenals de andere hier gebruikte uitdrukkingen ter aanduiding van de hoogedele afkomst van het kind. In 144/22 wordt het woord widjil alleen in dezelfde zin gebruikt, mogelijk een schrijffout, terwijl anak orang widjil in 198/21 syn. van sentana dalam schijnt te zijn. - rembesing (sp. N) madoe, 176/14, 196/4 id., jav. „honingzeem". N's spelling 176/14 wijst op de uitspraak rembasing madoe. - 21 toesing (sp. N) kesoema (N spelt nooit koesoema), 176/13, 182/6, 196/3, 203/3 id., jav. van zuiver vorstelijke afstamming. Tegenwoordig noemt men te Tenggarong een kind uit de permaisoeri geboren anak kesoema (vgl. Aanh. vdW), waarbij kesoema adjectivisch wordt gebezigd (vgl. 127/19: anak jang kesoema), of anak toetoes. Ook.in 't bdj. betekent toetoes van zuiver vorstelijke afstamming. Vgl. ook $\mathrm{KBW}$ sv. totos. - 23 melain, ook bij $\mathrm{N}$, vergissing voor melainkan. 24 anak tjoetjoe, met Tromp aant. 76 te vertalen: familiebetrekkingen, misschien zelfs nog ruimer, als mal. anak boeah. De letterlijke betekenis vindt men ook, o.a. 120/5 v. - mengasoeh, 128/31 id.; koet. ngasoh betekent evenals bdj. masasoeh bepaaldelijk op schoot hebben, asohan (bdj. asoehan $)=$ schoot. De mal. bet. is secundair. Pengasoeh (bv. 129/3) heeft in de Sal. de gewone mal. bet. - 28 awak oendangkan, air sehari-hari (lees sehari-sehari) akan air mandinja. Hier is bedoeld de ceremonie van het mengoendang air, letterlijk het water uitnodigen, d.i. het water met zeker ceremonieel opscheppen, wat gewoonlijk in het midden der rivier geschiedt, zoals voor het jaarlijkse hof-érau. Aan de oever wordt het opgeschepte water plechtig ingehaald en naar de kraton gebracht, hetgeen memapak air, het water afhalen, wordt genoemd. Blijkens de tekst (176/4 en $127 / 11$, conj.) geschiedt het mengoendang air voor het kind echter aan de rivieroever. Van het grondwoord oendang vindt men de volgende afleidingen in de Sal.: $133 / 25$ mengoendang (133/31 di-), uitnodigen; $133 / 8$ en pass. orang oendangan, genodigden. Het jav. woord heeft in het huidige mal. algemeen burgerrecht verkregen. - 29 djangan sekali-kali engkau tidjakkan ketanah maha-maha enz. slaat op de ceremonie van het tidjak tanah, het voor het eerst in aanraking brengen met de aarde, waarvan men 
de beschrijving vindt op bl. 129 v., 133 vv., 135 vv. Tromp vertaalt „laat hem dan niet de bloote aarde betreden", en tekent erbij aan (aant. 77) ,maha $=$ slechts; orang maha $=$ gewone man, een vrije (noch slaaf, noch pandeling), niet tot de aanzienlijken behoorende; tanah maha = bloote aarde." Maha is inderdaad koet. = mal. sehadja . Maha-maha is hier echter adverbiaal gebruikt in de betekenis zo maar, mal. sembarangan. Djangan awak pemaha-maha $(174 / 17)=d j$. $a$. pemoedah-moedahkan (119/19), behandel of beschouw het niet en bagatelle. Van orang maha, een gewone sterveling, geeft 156/30 een voorbeeld. - 30 engkau iraukan, lees e. éraukan. Tromp aant. 78: „erau $=$ gewone naam voor het feestvieren aan het hof te Tenggarong; (ook, als ik mij niet vergis, in de Lampongs)." Deze definitie is niet geheel juist; aan het eigenlijke érau kunnen weken van inleidend ceremonieel (merangin) voorafgaan. Ook is het érau niet aan het hof gebonden. Het melas tanah, zoals dat in 1940 gehouden werd te Kotabangoen wegens een geval van incest (koet. sahoe, vgl.' Oend. B.N. fasal 52, waar men dit iplv. sjahwa leze) werd ook érau genoemd. Wel was voor het houden hiervan de toestemming van den Sultan vereist, terwijl sommige ceremoniën zijn uitsluitend privilege zijn. De duur van het hof-érau is zeven dagen of een veelvoud daarvan. Het tepoeng tawar of pelas (vgl. Tromp aant. 30) is hierbij slechts een onderdeel, hoewel het voornaamste, van het ceremonieel. Lamp. iraw is volgens Van der Tuuk de "naam van een feest waarbij in vroegere tijden een mensch geofferd werd, nadat men op hem gedanst had; dit feest werd ter uitwissching van smaad gegeven" (TBG 18, 118). Het koet. érau zal vroeger ook wel een bloediger karakter gedragen hebben dan thans. Zo weet men, te recht of ten onrechte, nog te vertellen, dat de haan, die op de laatste dag van het jaarlijkse hof-érau boven het hoofd van den Sultan wordt geslacht, en met welks bloed hij zijn eigen voorhoofd en dat der hooggeplaatste omstanders aanstipt - begoros heet de ceremonie - in de plaats is gekomen van een varken en dit weer van een mens. Ook lijkt het mij waarschijnlijk, dat vroeger bij het pelas bloed te pas kwam. Zie de aant. bij 171/28. 't Woord érau vindt men in de Sal. 245/11 (radja soedah berhenti érau) en 250/26 (radja hendak érau) verbaal gebruikt, evenals in Oend. B.N. fasal 24 (radja érau). 127/32, 128/12 mengéraukan (engkau éraukan hier en pass.) betekent érau voor iemand vieren, of liever, de érau-ceremonie aan hem voltrekken, hem ,érauen". Ook in het Boeloenganse heten grote ceremoniële feesten érau. Vgl. tenslotte nog bdj. (dialect van Martapoera) irau, feest met 
eterij, gewoonlijk gebruikt voor de slametan op de ochtend van de huwelijkssluiting, en mal. érau, condoleantievisite (volgens Wilk.).

\section{0}

1 bawa, $\mathrm{N}$ leest steeds bawas volgens koet. uitspraak. - 2 terada (vgl. 144/20, 202/20/33, 204/2, 264/5, 265/12) wordt hier als syn. van tiada gebruikt, soms, en dat in overeenstemming met het hedendaagse koet. spraakgebruik, als een hoog woord hiervoor (gewoon koet. mandis, ndis - vgl. md.-mal. - of ehés $)$. — toeroenkan air, men zou t. keair verwachten. De hier bedoelde ceremonie van het voor het eerst naar de badplaats brengen (menoeroenkan ketepian, 129/23) volgt volgens de beschrijvingen (130/31 vv., $136 / 3$ vv., $179 / 8$ v. - toeroen keair besar) onmiddellijk op het tidjak tanah; vgl. Tromp aant. 71. 6 djoemenang; $\mathrm{N}$ leest gewoonlijk djemenang naar de normale uitspraak. Tromp aant. 79 vertaalt ,een vorstelijken titel krijgen.” Het is het jav. djoemeneng, ,de waardigheid bekleden van, de titel voeren van, optreden als." Hier en pass. djoemenang ratoe, doch 259/24 vv. wordt djoemenang ook gezegd van ,heten, genaamd worden" van vorstelijke personen na hun dood. Afleidingen: 225/27, 238/15 mendjoemenangkan (260/5/12 en pass. $d i$-) met dubbel object: iemand bekleden met de waardigheid van (ratoe), jav. andjoemenengaké. Ditzelfde wordt ook uitgedrukt door mendjenangkan (249/32; di-250/29). Voor djenang zie 183/26. - 7 kedang lees kadang. $-9 \mathrm{~N}$ als Tnt. 6 . doch abusievelijk met twee punten boven het $n$-teken, vandaar B's lezing. - 10 moeksa, Tromp aant. 80 ,moekhsa $=$ ghaib $=$ verdwijnen", lit. jav. Het is thans in koet. niet bekend, vandaar K's (onjuiste) verandering in mangkat. Vgl. de parallelle passages 196/6, waar alle hss. hilang lezen en 229/27, waar een ook al niet goed meer begrepen moesna van $\mathrm{N}$ door $\mathrm{B}$ is vervangen door lenjap en door $\mathrm{T}$ verknoeid. dimata-mata, id. 196/6. $D i$ heeft hier de functie van mal. dari, vgl. 125/3 di Tandjoeng Parangan laloc ke Tandjoeng Rizeana; 131/19 maka bertoeroenanlah oepatjara didalam (uit de kraton); 139/25 dikeloearkannja dimoeloetnja; 169/11 disamboetnjalah anakanda itoe diatas ajoen, enz. Dit gaat terug op het koet. spraakgebruik, waarin $d i$ evenals in het min. en atj. wordt gebruikt voor zowel de plaats waar zich iets bevindt als de plaats waar iets vandaan komt. Dit geldt ook voor het bdj., en hieruit is het te verklaren, dat men in de bdj. litteratuur vaak dari aantreft in de zin van mal. di (vgl. Sj. Hémop 37, 580 en pass.), een begrijpelijke verwarring, die men ook in de mal. omgangstaal van 
sommige Bandjarezen kan waarnemen. - 14 serta dengan baik parasnja, Tromp aant. 82: „Hoewel niet genoemd, moet dat „,nja” op kind slaan ...." Waarschijnlijk zijn er enige woorden uitgevallen. - 18 soeri widja, N spelt wورويجا , vgl. 124/5, waar voor B seri widja wordt opgegeven, doch $\mathrm{N}$ sizeidja schrijft. Tromp aant. 83 : „,serriwidja, wordt gezegd een soort rijst te $z$ ijn; vermoedelijk is $\ldots$. sĕri $=$ de naam van de rijst en widja = kleur." De juiste uitspraak noch de betekenis van deze fraaie benaming zijn bekend. Widja zal wel het ojav. woord zijn, dat beras betekent, en dat volgens KBW ook bidja luidt, dat in de combinatie bidja koening voorkomt. Hoewel seri of soeri (vgl. doemi naast demi) als naam voor rijst wel zou passen, lijkt mij de lezing vooralsnog twijfelachtig. - meminta, $\mathrm{N}$ hier en pass. memintas volgens koet. uitspraak. - $19 \mathrm{v}$. éjang - pilara. Hoe deze woorden gelezen moeten worden of wat ze betekenen ben ik niet te weten kunnen komen. Blijkbaar hebben wij te doen met het begin van een toverformulier. 196/1 wordt het tweede deel hiervan nogmaals aangetroffen. Daar doet degeen, die het uitspreekt, een beroep op zijn hoge afkomst om een wonder te kunnen bewerkstelligen. Dit is ook de gewone vorm van dergelijke toverformulieren in de bdj. volkslitteratuur, die steevast beginnen met de geheimzinnige woorden riang-riang ari boedjangga, riang-riang ari pakoeloen, waarna in verschillende bewoordingen wordt gezegd: ,indien ik van slavenafkomst ben, dan moge het niet slagen, doch indien ik van vorstelijken bloede ben, dan moge dat en dat (steeds een wonder) geschieden." Deze formule uitspreken heet bariang-riang, een verbastering van mal. beriang-iang. Dit laatste moet hier r. 23 gelezen worden iplv. berajang-rajang. Wilkinson geeft ,beryangyang” weer met "to pray to the old Gods or any one other than Allah", en in de door hem geciteerde voorbeelden wordt er inderdaad bij gezegd tot (kepada) wie men zich daarbij richt. Ook in Maxwell's Sri Rama komt het woord enige malen voor, evenals in de Sal. met een alif gespeld, steeds wanneer een wonderdaad bewerkstelligd moet worden. Gewoonlijk (69/17, 82/2 v.o.) staat er kepada segala dérwata bij, doch 75/1 v.o.vv. vindt men maka Kera Ketjikpoen beriang-ianglah memanggil segala hoeloebalang lasjkar racjat bala tenteranja menjoeroeh tebas djalan betoel menoedjoe negeri Bandar Tahwil. Het noemen van een voorwaarde, waarvan de vervulling van de wens afhankelijk is, evenals bij het bdj. bariang-riang, vindt men t.a.p. 69/17: maka Kera Ketjikpoen beriang-ianglah ia kepada segala déwata: djikalau soenggoeh lagi akoe sakti, maka mendjadi apilah poelau Katjapoeri semata-matanja 
itoe. De analogie van de bdj. uitdrukking doet vermoeden, dat éjang als iang gelezen moet worden. De volgende woorden zijn echter duister, en het lijkt mij gevaarlijk de uitdrukking zonder aanwijsbare parallellen te "herstellen”. Tegen de bij Snouck Hurgronje bl. 115 vermelde conjectuur van $\mathrm{H}$. Kern „ya nguwehi anak dewa ya nguwehi palar”, waarbij is uitgegaan van de gedachte, dat de volgende woorden een vertaling of parafrase van deze crux inhouden, is o.a. in te brengen, dat het geenszins zeker is, dat wij hier een jav. uitdrukking voor ons hebben. - 21 hoedjoeng, $\mathrm{N}$ spelt naar koet. uitspraak oedjoeng. Tromp aant. 84: „hoedjoeng $=$ beteekent hier: nakomeling." Elders spelt Mees oedjoeng, vgl. 260/13, 261/29 tiada beroedjoeng, 261/12/27 tiada menaroeh oedjoeng, geen nakroost hebben, 262/29/31 vv. membawa oedjoeng, nakomelingen hebben. Oedjoeng is thans nog slechts gebruikelijk in de taki-taal, doch de spreektaal kent nog het woord pehoedjoengan in dezelfde bet., bv. mandis ada pehoedjoengan, heeft geen nakroost. - sepandakoe, lees sepanedakoe, van jav. paneda, $\mathrm{kr}$. bij pandjaloek, vraag, verzoek; vgl. 163/9 sepeneda. Het woord doet hier dienst als taki-syn. van peminta. Het voorafgaande woord adalah is vreemd. Men zou adakanlah verwachten, doch 196/4 heeft hetzelfde: adalah sepemintakoe. - $22 \mathrm{~N}$ als Tnt. 11. - 23 berajang-rajang, lees beriangiang. - seketika, $\mathrm{N}$ leest hier en elders steeds (se) koetika. - 29 memantjoer, N memantjar, vgl. ook 127/1.

\section{1}

$4 \mathrm{~N}$ pesannja - déwa is in $\mathrm{N}$ in margine toegevoegd met gebruikmaking van de angka $r$ als verwijzingsteken, vandaar T's déwa ${ }^{2}$. $7 \mathrm{~N}$ anaknja na poesatnja (editie Tromp id.!) - Sapoe Djagat, 131/23, $192 / 26$ en pass. id. Een zo geheten kanon wordt te Tenggarong nog onder een gele klamboe bewaard. In de bdj. litteratuur is het een van de geliefdste namen voor een kanon, vgl. Sj. Hémop 1183. Zie ook Gentar Boemi 131/23. - 10 manoeknjapoen; koet. manos, hoen, onderscheiden in manos laki en manos bini. Wanneer het geslacht er niet uitdrukkelijk bij vermeld staat, als bv. 126/26, 130/22, betekent het in de Sal. altijd „haan”, gelijk op deze plaats, $140 / 28$ vv. en pass. Het woord ajam wordt in de Sal. n.f. slechts drie keer aangetroffen, nl. $134 / 7 / 21,135 / 11$, en dan voor het hoen als slachtdier. Ofschoon $130 / 22$ hiervoor het woord manos wordt aangetroffen, is het toch wel mogelijk, dat het woord ajam speciaal voor slachthoenders gold. Hetzelfde vond ik toevallig onlangs in het Boekit-dorpje $\mathrm{Pa}^{\mathrm{s}} \mathrm{au}$ (Riam Kanan), waar 
men mij ongevraagd vertelde, dat het algemene woord voor hoen daar vroeger, d.i. voordat men was begonnen in taal en gebruiken de Bandjarezen zoveel mogelijk na te volgen, manoek luidde, terwijl hajam alleen werd gezegd van geslachte kippen. - $16 \mathrm{~N}$ basoema iplv. berhoema, de gekuiste spelling. Koet. besoema heeft evenals bdj. bahoema bepaaldelijk de bet. rijst verbouwen, hetzij op droge of natte gronden. 19 baroet wordt door Tromp met ,smeersels" vertaald. Het betekent in koet. echter compres op de buik, is dus ongeveer gelijk aan de voor het mal. opgegeven bet. en anders dan min. baroeis. -20 déwa dan belian; van de werkzaamheden dezer mannelijke en vrouwelijke priesters geeft Tromp in aant. 83 belangwekkende bijzonderheden. Nog steeds zijn zij de officianten bij het érau. Gewoonlijk is er in de Sal. sprake van een veertigtal déwa's (171/28 v., 226/8/30 en pass.). De gewone bet. $119 / 15$ en de daarop volgende passage. - anak is in $\mathrm{N}$ door een andere hand ingevoegd. $-23 \mathrm{~N}$ als Tnt. 5; B's inja is bdj. pron. pers. $3 \mathrm{e}$ pers. $-24 \mathrm{v}$. $\mathrm{N}$ spelt hier en pass. galab(lah) iplv. gelap(lah). - 30 disangkanja hari hendak balik; Tromp's vertaling ,zij dachten dat de wereld zou vergaan" wordt bevestigd door de glosse, die men mij gaf : „langit hendak roentoeh, boemi maoe hantjoer, maoe kiamat." Hetzelfde is bedoeld met balik, 140/3. - 31 perapi, $\mathrm{N}$ parapi, in overeenstemming met koet. uitspraak. Tromp geeft het in aant. 90 terecht als syn. van mal. para-para, af te leiden van een para api. De voor de hand liggende samensmelting tot één woord evenzo in het Angkola-Bataks. - 34 berdjerang; bedjerang, absoluut gebruikt, betekent in het koet. rijst koken (in een pot), evenals bdj. bamasak. Vgl. 157/16: disoeroehnja djerangkan oléh poeteri itoc, maka orangpoen mendjeranglah dan mengganganlah ia, de prinses liet rijst voor hen koken, en toen kookte men rijst en sajoer. Met object 167/17/20 (beras majang) didjerangnja. -36 berkeliling-keliling; $\mathrm{N}$ spelt gewoonlijk koeliling in grondwoord en afleidingen.

\section{2}

$1 \mathrm{~N}$ merentas iplv. meroentas; koet. rentas $=$ mal. retas, vgl. 165/8, waar $\mathrm{N}$ rantas spelt, gezegd van een tangga. Kedah rentas, bdj. rantas id. - kasau laki,$=$ kasau-djantan = hoofdspanrib" (Tromp aant. 91). Laki betekent in deze tekst meermalen, in overeenstemming met koet., niet alleen man (echtgenoot), maar ook mannelijk van mensen (mal. laki-laki) en dieren en dingen (mal. djantan); evenzo betekent bini vrouw (echtgenote) als mal. en ook vrouwelijk van mensen (mal. 
perempoean) en dieren en dingen (mal. betina). Vgl. 158/2 manoek laki, 158/3 manoek bini, verder 125/30 laki-bini van een dubbele regenboog, $130 / 18$ vv. en pass. van paren dieren. Als mal. 129/25 orang laki-laki en orang perempoean, 122/18 boedak-boedak perempoean, 245/18 pengantén laki-laki, maar $236 / 17 \mathrm{v}$. en $237 / 34$ weer pengantén laki (-bini) enz. Voor 139/5 jang laki en jang bini (nl. orang), de mannen en de vrouwen, leest men elders weer (jang) laki-laki en (jang) bini-bini $(192 / 5 / 9)$. In het bdj. maakt men onderscheid tussen bini, echtgenote vrouwelijk van dieren en dingen, en bini-bini (babini, bibini), vrouw, vrouwelijk van mensen $=$ mal. perempoean en m.m. tussen laki en laki-laki (lalaki). Ook in het br. betekent bini-bini ,female of human beings". - N dipotosnja iplv. dipotongnja (evenals hs. B, zie Snouck Hurgronje, bl. 112, noot 2); koet. poto ${ }^{5}=$ mal. potong; vgl. $123 / 13$ sepotos, 209/21 memotos, 209/24 potos kepalanja. - 2 sawa wordt in koet. en bdj. steeds zonder het generieke woord (koet. tedong, bdj. oelar) gebruikt, in tegenstelling tot andere slangennamen. Zo noemt men ook in het ng. de python steeds panganen zonder meer (vgl. Hardeland sv. handipä). $-3 \mathrm{~N}$ ditaroeh (nja didalam tempat) sirihnja iplv. ditaroeh sirihnja. Het tussen haakjes geplaatste is onderaan bl. 5 van het hs. bij wijze van rakibah (,,custos”) geschreven, doch wordt abusievelijk niet op bl. 6 herhaald, vandaar B's omissie. - N disapoe-sapoenja. -8 diboeatnja, enz. „deed hij hem in een nog veel groter verblijf." In $\mathrm{KV}$ doet men de slang uit de sirihdoos eerst verhuizen naar een draagmand en vervolgens naar de rijstbewaarplaats. Koet. mboeat kedalam, plaatsen in, doen in, evenals bdj. mamboeat ka(dalam). In 't bdj. zegt men ook baboeat, zich inschepen. Ook in 't sd. vindt men deze betekenis van boeat weer. Voor andere talen zie KBW sv. brwat IV. In de Hikajat Atjéh, een der oudste mal. handschriften der Leidse Universiteitsbibliotheek, vindt men diboeatkan in de zin van "gezet worden op" (een olifant). Voor het in een zelfde verband aldaar voorkomende بونكن. zal boeatkan gelezen moeten worden. (Vgl. H. Djajadiningrat, Bijdr. 65, 1910, bl.241, aant. 7). $11 \mathrm{~N}$ ini later ingevoegd. - $12 \mathrm{~N}$ als Tnt. 6 ( دي ) - $13 \mathrm{~N}$ kata. -

$15 \mathrm{~N}$ maka ontbr. - $\mathrm{N}$ berapa. - 16 naga; dat de saza hier een naga wordt, is in overeenstemming met het wijdverbreide volksgeloof, dat een sawa, als hij zeer groot en oud wordt, in een naga verandert, of zoals de Bandjarezen het uitdrukken: de naga is de katoehaan van de sawa. Volgens de Ngadjoe's veranderen oude panganen's zich in tambon 
of naga (Hardeland sv. panganen). De Atjehers vertellen van de bintiëng (een andere slangsoort) hetzelfde (Djajadiningrat, Atj. Wdb. sv. oeleuë). - 18 boedak-boedak, de verdubbeling vermoedelijk naar analogie van kanak-kanak. - 21 akandikoe, lees met $\mathrm{T}$ akan diakoe, vgl. 144/22 id., 159/8 dengan diakoe en 162/24 mentjoba diakoe. Ook van het pron. pers. $2 \mathrm{e}$ pers. vindt men de vorm met di-: 189/32 dibawaslah kediawak, 190/1 mengangkat diawak, 249/20 mengadjar diawak, en voor de 3e persoon: 203/1 menjembah didia. Uit deze voorbeelden blijkt, dat de met $d i$ - uitgebreide vormen der pronomina personalia niet alleen na op een $-n$ uitgaande woorden kunnen optreden, zoals mal. dakoe en dikau, doch in het algemeen na praeposities en wanneer het pronomen als object van een me-vorm fungeert. Het is geen hedendaags koet. spraakgebruik, doch in het bdj. is het nog levend. 22 tempat koetoeroen, lees met $\mathrm{N}$ tempatkoe toeroen, vgl. 126/28 tempatkoe menghidoepi anakkoe en de aant. bij 125/10. - $23 \mathrm{~N}$ leest hier en elders gewoonlijk terkedjoed. -31 poepoes, 132/9/13, 138/25 en pass. id., koet. klaar, gereed, af (vgl. mal).

\section{3}

$1 \mathrm{~N}$ berkata iplv. katanja - dengan = mal. kepada vindt men ook 168/27 en 160/21: boenji Adji itoe dengan kekanak doea orang itoe, de Vorst sprak tot de twee knapen, in overeenstemming met koet. spreektaal, welke, zoals reeds opgemerkt, geen kepada kent. - $4 \mathrm{~N}$ $b a p a^{s} n j a$, en overal elders $b a p a^{s}$ iplv. bapa. $-5 \mathrm{~N}$ sepotos iplv. sepotong, 13 id. (hs. B id., vgl. Snouck Hurgronje, bl. 112, noot 2). 8 mengerahkan; T's lezing menjoeroeh is een emendatie, daar zijn voorbeeld mengarahkan heeft. Volgens een niet geheel zekere inlichting betekent inderdaad in koet. ngerahkan meer bevelen tot het gemeenschappelijk verrichten van iets, dan bijeenroepen tot enz., welke laatste betekenis voor het mal. geldt. Vergelijk sd. grah, dat wordt weergegeven met "to order, command", doch de gegeven voorbeelden doen vermoeden, dat het steeds met meervoudig object wordt gebruikt. Is de gegeven verklaring niet juist, dan kan men de constructie als een soort contaminatie verklaren. $-13 \mathrm{~N}$ sepotos iplv. sepotong (hs. B id., vgl. r. 5). - $14 \mathrm{~N}$ tangga later ingevoegd. - patah-mematah, $23 \mathrm{id}$. = berpatahan van r. 6 , is een koet. vorm; in het mal. heeft de vorm reciproque betekenis. - 17 toelian, ijzerhout, de koet. benaming voor Eusideroxylon Zwageri, ook telian uitgesproken. -- 22 diandarkannja, iplv. 't geen zin gevende dioendoerkannja; koet. ngandarkan, iets met 
het uiteinde op iets anders leggen, het er zo op doen rusten, vgl. min. anda I (Kamoes). - 28 uit kita blijkt, dat plotseling tot de directe rede wordt overgegaan. Het kan een stijlfout zijn, doch waarschijnlijk is er iets uitgevallen, in welke richting ook het niet passende jang aan het begin van deze regel wijst. - lampoeng soeit; naar mijn vriend P. Bouma mij meedeelt verstaat men onder lempong soeit in Koetai een Euphorbiacee met heel zacht, wit hout, voorkomend in secundaire bossen. Lempong is overigens een verzamelnaam voor Shorea-soorten. - 33 indoeknja sc. tangga; indoes is een dialectische uitspraak van gewoon koet. indoe, zoals $\mathrm{KV} 16$ heeft. Indoe tangga = mal. iboe tangga; evenzo indoe tangan, indoe betis = mal. iboe tangan, iboe kaki. - bamboe ding, lees bemboeding koet. een volgens de beschrijving sprekend op de pinang gelijkende palmsoort, slechts veel dunner van stam en minder hoog. Tromp's verklaring in aant. 95 ,ding $=$ een soort bamboe" is reeds daarom onbestaanbaar, omdat bamboe geen koet. is. - N lemiding iplv. lembiding, volgens koet. uitspraak, Stenochlaena sp. (Endert Exp. bl. 295). - $34 \mathrm{~N}$ djika iplv. djikalau.

\section{4}

4 widjén; de koet. uitspraak is wédjén, zwarte sesam is wédjén itam. Erang, of liever hirang (bdj. vorm), zoals B en N spellen, is blijkbaar gebruikt als een mooi woord voor zwart, vgl. 189/7. Het branden van zwarte sesam door enkele korreltjes ervan te laten vallen in een test met gloeiende houtskool gaat te Tenggarong steeds aan het strooien van gele rijst vooraf. - N سي ويجا iplv. seri widja. - $7 \mathrm{~N}$ doea (evenals ed. Tromp!) iplv. doedoek; een latere hand heeft in $\mathrm{N}$ de, in een $\mathbf{j}$ veranderd door er twee puntjes op te plaatsen, ten onrechte, doch het verklaart B's lezing. - $13 \mathrm{~N}$ berkata iplv. berkata-kata; (poen berkata is in $\mathrm{N}$ in margine ingevoegd met angka $\square$ als verwijzingsteken). -15 dinihari moeda, koet. het allereerste morgengloren, \pm drie uur 's ochtends. - $21 \mathrm{~N}$ santap laloe na soedah (vgl. Tnt. 5). 22 beramoe, $142 / 21$ id., koet. en bdj. = mal. meramoe. $-27 \mathrm{~N}$ als Tnt. 7. - 29 berkiloerlah, lees berkélorlah; koet. bekélor, schuifelen, kruipen als een slang. $-33 \mathrm{~N}$ als Tnt. 10; men leze: ke Tepian Batoe.

\section{5}

$1 \mathrm{~N}$ laloelah $-\mathrm{N}$ diiringkannjalah -2 Tepian Batoe bevindt zich vlak bij Koetai Lama. Bij laag water komt daar een platte steen blnot. 
- Tandjoeng Parangan? - 3 Tandjoeng Rizwana, tegenwoordig uitgesproken $T$. Roeana (KV 22 id.), naam van een tandjoeng, ongeveer tegenover Soengai Meriam. - 4 na maka volgt in $\mathrm{N}$ ilanglah, doch dit is door den schrijver zelf doorgehaald (vgl. Tnt. 5). - 7 mengikipkan, Tromp aant. 99 ,nabij brengen”. Geen mijner helpers kende het woord. Een hunner stelde voor te lezen mengepaikan, het koet. syn. van mal. mengepilkan, van welk laatste woord de lezing van het hs. evengoed een verbastering zou kunnen zijn. -8 menedoehkan ombak dan riboet betekent niet: (het bootje) voor de golven en de wind in veiligheid brengen, welke vertaling van Tromp ook een grammaticale moeilijkheid oplevert, doch wachten tot deze zijn gaan liggen, ze laten betijen. Mogelijk is ook: schuilen voor golven en wind (vgl. melarikan ombak, 125/17). $-10 \mathrm{~N} !$ iplv. ia, zoals ook 161/15, 162/17 (B inja), 167/8, $175 / 3,222 / 33,233 / 28$, te lezen enja, of fonetisch juister ' $n j a$ (monosyllabisch), koet. pron. pers. 3e pers., waarmee een vorige opgave (nja, in Bespr. 300, noot 1) zij verbeterd. Ik meende destijds ook, dat in 161/15 sebabnja (TK), 170/14 asalnja, 180/10 akannja, 195/4 seketikanja (B), 255/10 soedahnja, nja als een apart woord diende beschouwd te worden, omdat er een praedicaatswoord, dat $n j a$ tot logisch en ook grammaticaal subject had, op volgde. Ofschoon $\mathrm{N}$ op twee der aangehaalde plaatsen inderdaad een zelfstandig pron. pers. heeft (scbab enja, sekoctika ia), schijnt het mij nu toch toe, dat de spelling niet onjuist is, en de pronomina inderdaad enclytisch en in zekere zin als possessiva zijn te beschouwen. Men vergelijke 122/22 tempatkoe toeroen, het middel, waarlangs ik kan afdalen, 126/28 tempatkoe menghidoepi anakkoe, het middel, waarmee ik mijn kind in leven kan houden, 173/18 akan tempatnja bermalam, waarin zij konden overnachten (om in te overnachten). Deze gewone mal. constructie verschilt in wezen niet van die der boven aangehaalde voorbeelden. Men vergelijke nog 154/21 dibetisnja tidoer, ,bij de voeten van hem (die) sliep”. Eveneens enclytisch, doch hier als object fungerend, is $-n j a$ in 145/6 biarnja en $125 / 25$ siapa tahoenja, koet. uitdrukkingen, die evenzo in het bdj.

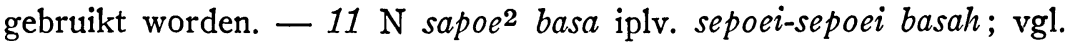
$125 / 32,138 / 2,237 / 5$ sepoe $^{2}$ basa; beide uitspraken komen volgens Wilkinson ook elders voor; 239/26, 245/31, 248/2 sepoe 2 basah, waarin basah $=b a(h a) s a$ (vgl. Wilk.). -13 membentang, 137/33, $237 / 5$ id., koet. zich uitstrekken .v.e. regenboog $=$ mal. merentang (bv. Mésa Kagoengan bl.7). Voor het koet. gaat dus Wilkinson's verklaring sv. rentang, dat bentang ,extension in all directions” zou betekenen, 
niet op. - 17 Soengai Sedizué? - 18 berpandir-pandir, 145/23, 151/21 en pass. id.; bepandér, koet. bdj. met elkaar praten. Vormen: 151/7 memandér, 207/32 en pass. memandér-mandér, zelfde bet.; 195/21 v. memandér(-mandér)kan, bespreken, bepraten; 228/17, 230/13 barang pandér dipandérkan. - 19 vv. boenji, 140/8, 146/13 en pass. id., koet. $=$ mal. kata of oedjar, in de Sal. met kata afwisselend. Zo r. 22 berboenji $=$ mal. berkata. -22 jang, 34 en pass. id.; zou volgens mijn helpers gelijk te stellen zijn aan hiang, en op de goddelijke afkomst van Baboe Djaroema moeten wijzen. Waarschijnlijker is het, dat het een afkorting van de ook in Koetai bekende titel dajang (vgl. Tromp, bl. 19) is, zoals ook in andere mal. streken, vgl. Wilkinson sv. yang III. 23 kanak-kanak, kind (puer, puella) gewoonlijk bij N kekanak (127/31, $156 / 16 / 20$ vv. en pass.) en eens kanak (128/28). Het laatste is thans het gewone woord in koet. - 24 awak ini sedengar-dengari sadja; Tromp vertaalt ,ik luister ook al”, wat onjuist is. Awak ini betekent niet „ik” doch „,jij hier”. Voor sedengar-dengari moet men lezen sidengar-dengari, koet. maar van alles horen. Vgl. sitjioem-tjioemi, maar links en rechts kussen, simakan-makani, maar van alles eten, alle uitdrukkingen in ergernis uitgesproken. - siapa tahoenja, zie aant. bij r. 10. - 28 laoet betekent in koet. en bdj. niet alleen zee, doch ook „het ruime sop" in de zin van het midden van een rivier, en verder: waterkant in tegenstelling tot landkant (darat). Vgl. 253/24 ia dilaoet kita didarat, zij bevinden zich op het water, wij op de wal. Melaoeti in r. 24 wordt door Tromp vertaald met ,van wal steken”. Volgens een opgave van Klinkert komt dit woord in de Hang Toeah voor als syn. van melaoet „,van het land afhouden”, dus eveneens zonder object als het woord in onze tekst. Ik vermoed echter, dat het object hier is verzwegen. In het bdj. betekent malaoeti tenminste zeer bepaald: naar iets, wat zich in het midden van de rivier bevindt (gewoonlijk een vaartuig of een stuk drijfhout) toevaren van de kant af. - 30 ketari, 131/27 en pass. id., koet. regenboog (vgl. Aanh. vdW en Tromp's vertaling). Tromp's aant. $162,=$ tedja = glans licht” is foutief wat de Nederlandse verklaring betreft. Bdj. tédja, dat men Tromp als vertaling van ketari opgaf, betekent eveneens regenboog. Hier is sprake van een dubbele, waarbij zoals gewoonlijk bij het optreden van twee bij elkaar behorende ongeveer gelijke voorwerpen of natuurverschijnselen, onderscheid wordt gemaakt tussen een vrouwelijke en een mannelijke. De laatste is natuurlijk de bovenste evenals de tédja laki der Bandjarezen. - $32 \mathrm{~N}$ sepoe ${ }^{2}$ basa iplv. sepoei-sepoei basah. 
$1 \mathrm{~N}$ spelt steeds kemala. $-2 \mathrm{~N}$ na dilihatnja is later ada ingevoegd. - 4 naga-naga; het verbindingsstreepje behoort te vervallen en bij gebruikmaking van leestekens door een komma te worden vervangen. 6 Lemboe Soeana, 137/26 vv. en pass. id.; de naam zal wel evenals sato sembawa van Java afkomstig zijn. Men vergelijke jav. Lemboe Sana, de naam van een boeta in de lakon Kandiawan (Vreede, Catalogus Jav. hss. 242). Twee koperen beelden van dit mythische dier, in recente tijd gemaakt, prijken thans ter weerszijden van de troon van den Sul$\tan$ van Koetai. De hier meegedeelde mythe van de geboorte der stammoeder van het Koetaise vorstenhuis geeft de verklaring van de centrale en heiligste ceremonie van het jaarlijkse hof-érau te Tenggarong, namelijk de pelas- of tepoeng tawar-ceremonie. Het voornaamste onderdeel van de toestel, die hierbij in gebruik is, is de léman, de loper in de kleuren van de regenboog met daarop twee gekruiste slangen van tjindé, tegen welker koppen de gong aanligt, waarop de vorst tijdens de besprenkeling met tepoeng tawar zijn voet plaatst. (De koppen van de slangen rusten niet òp de gong, zoals Tromp, aant. bl. 78 wil). De léman ligt op een mat, waarop een figuur (karang) van in verschillende kleuren geverfde rijstkorrels is gemaakt, iedere der zeven dagen een andere. Voor de laatste dag worden er twee figuren op aangebracht: aan het voeteneinde der mat een symmetrische, achtpuntige figuur, welke men karang mendoengkoel noemt, aan het boveneinde een afbeelding van de Lemboe Soeana. Bij het vervaardigen van deze rijstmozaieken bezigt men van buffelleer gemaakte voorbeelden, die in de kraton worden bewaard.

Volgens de tekst werd bij de geboorte van de prinses de gong, waarop zij rustte, op de kop gedragen door de naga, de naga lag op Lemboe Soeana, en deze stond weder op een steen. In de boven beschreven toestel wordt eigenlijk hetzelfde vertoond, immers de slangen van de léman dragen als het ware de gong, waar zij met de kop tegenaan liggen, de léman rust op de beeltenis van Lemboe Soeana, die als het ware treedt op de onder hem afgebeelde karang mendoengkoel, welke dus blijkbaar de steen voorstelt, die in de tekst wordt genoemd. (In $\mathrm{KV} 23$ wordt deze karang inderdaad genoemd in verband met de geboorte der prinses.)

Bij het pelas nu plaatst de vorst om beurten de rechter- en de linkervoet op de gong - één keer pelas betekent niet, dat de vorst éénmaal de léman op en afgaat, zoals Tromp verklaart, doch driemaal; op de 
zesde dag wordt dit dus zes keer driemaal gedaan! -, en in die houding staande wordt hij besprenkeld met tepoeng tawar, terwijl de voornaamste der déwa's hem toezingt. In deze zang, waarvan de tekst helaas niet in mijn bezit is, worden de eerste dag de voeten van den Sultan dipoedja (vgl. 118/19), de tweede dag ook zijn bovenbenen, en zo voort, totdat op de laatste dag zijn gehele lichaam is aangeroepen. Tot en met de zesde keer is de Sultan poedja, zei mij Pangéran Tjokro (de bedoeling hiervan is blijkbaar ongeveer: in staat van formatie, nog geen volkomen mens), doch de laatste keer $\mathrm{danst}$ de vorst over de léman, omdat hij nu een mens (manoesia) is geworden. Gedurende deze ceremonie wordt het lichaam van den Sultan dus als het ware door heilige handelingen en woorden geformeerd. De betekenis van dit hoogtepunt van het jaarlijkse hof-érau, dat men met recht een Nieuwjaarsfeest zou kunnen noemen, schijnt mij eigenlijk te zijn de wedergeboorte, de jaarlijkse vernieuwing van het heilige lichaam van den vorst, tevens de plechtige uitbeelding, de opvoering, van de geboortemythe van de stammoeder, die in den vorst als het ware herboren wordt.

Bij deze verklaring is geen aandacht besteed aan de Madjapaitse krisjes, die op de léman zitten vastgenaaid, de steen, waarop de vorst even de voet drukt alvorens haar op de gong te laten rusten en het ei, dat bij de gong ligt. Blijkens Tromp's verklaring bracht men deze voorwerpen in verband met die, waarmee de stamvader van het vorstenhuis op aarde neerdaalde. Of de steen echter werkelijk ",herinnert” aan de batoe angkat-angkatan, zoals door Tromp wordt beweerd, is twijfelachtig. In tegenstelling tot de andere tot de léman behorende voorwerpen is deze steen namelijk niet heilig. In 1940 gebruikte men een platte stenen vijzel, doch men beweerde, dat evengoed een andere, willekeurige steen gebruikt kon worden. Het treden op de batoe angkatangkatan zou bovendien geen zin hebben. Het gebruik van de steen is vermoedelijk afkomstig van andere ceremoniën, waarbij de voet op een stuk metaal wordt gezet, nadat men ermee een steen heeft aangeraakt, zoals dat in de Salasilah voor het tidjak-tanah-feest wordt beschreven, en zoals men dat ook bij verschillende Dajakse ceremoniën aantreft. Men krijgt de indruk, dat de andere voorwerpen, die waarschijnlijk wel met de geboortemythe van den stamvader in verband staan, evenals ook de hier niet genoemde gouden bol, waarvan een klein model aan de tali djoeita tegen de sangkoh piatoe aanhangt, eigenlijk bij deze ceremonie niet thuis behoren. Mogelijk zijn het latere toevoegsels om ook den stamvader in het ceremonieel te betrekken. In 
dit verband zij er aan herinnerd, dat de met de aarde en het water geassocieerde stammoeder in de mythe een minstens even belangrijke, zo niet belangrijker rol speelt, als haar uit de hemel neergedaalde echtgenoot. In verband met de tandenvijling worden van haar alleen bijzondere daden vermeld, zij dwingt haar aanstaanden echtgenoot tot haar te komen, door zijn haan vast te houden, en zij is het, die bij haar terugkeer naar haar oorsprong aanwijzingen geeft omtrent de vorstelijke bijzettingsgebruiken, die haar nageslacht moet opvolgen. $-7 \mathrm{~N}$ berbilalai - 7-9 Behalve vóór gadjah zijn alle seperti's in $\mathrm{N}$ later ingevoegd. -8 bersirik; jav. sirig, trippelen, dansende gang van een gedresseerd paard, vgl. Wilkinson sv. sirek II. Als beschrijving van het uiterlijk (roepa) van een paard is het woord niet erg bevredigend, en ik zou daarom bersoerai, gemaand, willen lezen. Dat afschrijvers met dit woord geen weg hebben geweten is niet te verbazen, daar het paard in Koetai onbekend is. - 14 gobang, 17 id.; de koet. uitspraak is goebang, een algemene benaming voor verschillende soorten boomstamkano's. De naam schijnt welhaast beperkt te zijn tot bepaalde gedeelten van Borneo, vgl. Wilkinson sv. gobang, en Nooteboom, De Boomstamkano, 87 v. en 90 . De definitie van vdW, overgenomen door Klinkert sv. gobang II „e.s.v. klein vaartuig, dat zeer goed zeebouwt”, gaat althans voor Koetai niet op. Het slaat waarschijnlijk op het vaartuig der Orang Laoet, door Wilkinson perahoe goebang genoemd. 16 olah is niet, zoals Tromp in aant. 105 zegt, een syn. van gaiah, „lange stok met haak om vaartuigen voort te duwen", doch het koet. woord voor schepriem, pagaai $=$ mal. pengajoeh.$-\mathrm{N}$ vangt met het tweede egoeng een nieuwe bladzijde aan en leest daarachter nog itoe, een herhaling bij vergissing, die verantwoordelijk is voor de lezingen $\operatorname{van} \mathrm{T}$ en K. - dialaknja; ngalas , koet. = mal. mengambil. Vgl. 156/35, 157/3 mengalak; $157 / 1$ patik alak; 147/24 alaklah taroehmoe. Ontlening uit het Boeginees aan te nemen (vgl. Tromp aant. 106) is niet nodig; vgl. o.a. boes. en snd. ala. - 18 ladjoe, 25, 137/11, 197/1, 227/2 id. gebruikt in de zin van mal. laloe. Het is geen koet. spraakgebruik; vgl. jav. - moelang, in deze tekst voortdurend af wisselend met poelang (zie bv. 140/7 en 12) is koet. huiswaarts keren; $167 / 19$ in de zin van "terugkeren tot de oorspronkelijke staat van ...."; 154/5 bermoelangan = 179/11 berpoelangan. - $22 \mathrm{~N}$ spelt hier en elders vaak دؤو, daoeloe (koet.) - $23 \mathrm{~N}$ bedoengnja2nja iplv. bedoeng-bedoengnja; bedoeld is natuurlijk: bedoengnja, bedoengnja. - 24 poléng; Tromp verklaart in aant. $107,=$ tjindei $=$ gekleurde zijden stof”, waarschijn- 
lijk doordat zijn helper, evenals de mijne dat deden, het hield voor hetzelfde woord als poelangi (dezelfde dwaling vertoont B 168/8); het in Koetai thans onbekende woord is jav. ,een soort van geruit weefsel”. Zie ook 131/7. - 25 tigoe, 172/12 en pass. id., koet. = mal. teloer, welk woord in de tekst slechts eenmaal voorkomt (119/13). - setoelang, 174/10 en pass. id. ; toelang is in koet. een ongeveer even algemeen als mal. boeah gebruikt „hulptelwoord”; vgl. 153/9 waar het van een limau-vrucht wordt gebruikt.

\section{7}

$4 \mathrm{~N}$ als Tnt. 2. - 12 tetapinja; lees ditepian als 176/5. - 13 maka haroes, dan mag het; $176 / 5$ staat duidelijker: maka haroeslah ia mandi. - 21 na itoe hadden de aanhalingstekens gesloten moeten worden. $\mathrm{N}$ Djaroemapoen. - $25 \mathrm{~N}$ ia na dengan; beide woorden zijn later ingevoegd. $-30 \mathrm{~N}$ als Tnt. 19. - $31 \mathrm{~N}$ kekanak. - 32 bai, 134/5 id., lees baï, 134/5, 231/16 id., koet. bdj. = mal. babi.

\section{8}

1 lemboe, 130/19 id., koet. banteng, 't bekende wilde rund. $-2 \mathrm{~N}$ eerste dan ontbr. - gimbal, 130/20 id., koet. schaap, vgl. KBW sv. hangsa, waarom die $h$ bij Mees en Tromp? $\mathrm{N}$ spelt steeds angsa. en dat is ook de spelling van Van Ophuijsen. - 3 v. kerbau génggong en banténg menamang, 130/22 en pass. id., zijn volgens Tromp aant. 45 ,andere namen voor varkens". Varkens zijn echter in de opsomming reeds genoemd. Mijn zegslieden verklaarden zonder aarzeling, dat het verbloemde termen waren voor ,rat” en ,hond”, hoewel zij de letterlijke betekenis van génggong en menamang (een zijrivier van de Kedang Rantau heet Menamang) niet kenden. Het feit, dat een vorst dergelijke dieren slacht, zou op zijn grootheid en macht en zijn onderscheid van gewone mensen wijzen. Waarschijnlijk ligt de betekenis van het offeren van paartjes (zie o.a. 130/18) van de voornaamste vertegenwoordigers van de dierenwereld uit 's mensen omgeving evenzeer in het universele karakter van het offer als in het feit, dat de slachtdieren stuk voor stuk „magische dieren" zijn (vgl. Mees bl. $60 \mathrm{v}$.). -6 menempoesoe, 132/18 en pass. id., lees menemposo, zich voordoen als een temposo, koet. termietenheuvel $=$ mal. poesoe, boesoet. - menelaga, $132 / 18$ en pass. id. zich voordoen als een telaga. Dezelfde beelden vindt men $132 / 23 \mathrm{v}$. en $139 / 7$ v. van sepah en air pinang gebezigd. Voor verwante be- 
schrijvingen in de mal. litteratuur vgl. o.a. Sedj. Mel. 34/7 v. kerak nasi bertimboen-timboen seperti boesoet, air didih bagai laoetan, kepala kerbau lemboe seperti poelau en Hik. Sri Rama Maxw. 81/3 vv. kerak nasi mendjadi boekit dan darah kerbau lemboe mendjadi laoet tinggal (lees toenggal?) dan air didih mendjadi anak soengai. $-\mathrm{N}$ als Tnt. 3 peroempoeng, 130/4 en pass. id.; Tromp aant. 115 „een soort hoog riet, waarvan, als het brandt, de geledingen met harden knal openspringen." Het is glagah, Phragmites Karka (De Clerq 3132 en Endert Exp. 208). $-7 \mathrm{~N}$ spelt steeds diaroe; ngaroe, koet. = mal. meng(h)arau; bij katjang di(h)aroe, $130 / 4$ en pass. id., tekent Tromp aan (aant. 116) „,boonen die geroerd worden, .... zooals gewoonlijk geschiedt bij het braden van boonen in een ijzeren pan." $-17 \mathrm{v}$. beriringiring, elkaar op de voet volgen in figuurlijke zin. $-18 \mathrm{v}$. bebaja, koet. $=$ mal. bersama(-sama). Vgl. 132/28, 139/10 v. dipebajakan. Tromp geeft pebajakan in aant. 67 weer met "begeleiden", doch de betekenis is meer: gelijktijdig doen klinken, tesamen doen klinken. - menepas, koet. wassen van kleren, bdj. manapas id., sd. nepas, "to sweep”. 129/6, 177/22 penepas lampin, luierwaster. Tromp's lezing voor deze plaats „memapas” en zijn aant. 117 berusten blijkbaar op een misverstand. 20 Gadjah Perwata, 131/22 en pass. id., Tromp aant. 117a „,de groote gamelan van Djahitan-Lajar"; deze gamelan moet zich nog in de kraton bevinden, doch zij wordt niet meer bespeeld. - $\mathrm{N}$ dengan na Lajar (evenals $\mathrm{T}$ ed.). - Ejang Ajoe, 129/30 en pass. id.; N spelt hier

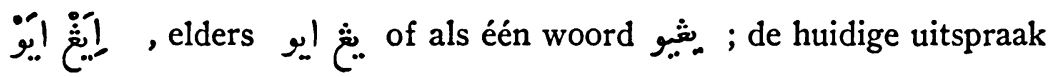
is $j a n g-j \partial$. Waarschijnlijk moet dus voor N's eerstgenoemde spelling iang iò gelezen worden. Tromp leest ten onrechte Jang-Jong en verklaart in aant. 117a, dat het "de groote gamelan van Hoeloe-Doesoen" is; in werkelijkheid is het echter een keléntangan (zie 134/9), welke ook nog bewaard is gebleven. De gelijkenis van de naam van dit muziekinstrument met de aanhef van het toverformulier van 120/19 zal wel louter toeval zijn. - 22 baloenja lees balōnja, 177/7 id.; balō is een taki-synoniem van ramboet, hoofdhaar, uit het Toendjoengs, vgl. ng. balau. - djeriangau is geen koet. uitspraak, doch bdj. (min. id.); vgl. $177 / 7$ djeringau. Voor het besmeren met onwelriekende stoffen zie behalve Tromp aant. 118 vooral Van Ossenbruggen, Het primitieve denken, $\S 157$ vv. - 23 selama; men zou eerder sesoedah of sedjak verwachten, doch 140/19/23 hetzelfde gebruik. - 24 ngabéhi, N spelt hier en elders gewoonlijk بع أي bdj. spelling voor koet. ngebé, bdj. 
ngabé ; alleen 203/19 spelt N ngabéi. Het woord is evenals de titel kia $(k i)$ in onbruik geraakt. - kiai, $\mathrm{N}$ spelt op enkele uitzonderingen na steeds $k i$ (vgl. r. 11). - 25 meraoen, $\mathrm{N}$ maroen, 177/4 id.; koet. meroen, een zekere akar kajoe met geneeskrachtige eigenschappen. Tromp's aant. 119 behoort bij het volgende woord raoen, doch is ook daarvoor onjuist (onder invloed van de mislezing mengemboen!). -26 piazeas, 177/5 id., Tromp aant. 120 ,boombladeren, voor geneesmiddel gebruikt." Mijn zegslieden kenden alleen de naam en het gebruik, niet de boom. Vermoedelijk is er niet de guajave (min. piawéh, mal. biawas) mee bedoeld, doch de boom, die in het mal. perawas, bdj. pirawas of parawas, ng. pahawas heet (Litsea odorifera of een andere Lauracee). Vgl. ook de Kroniek van B'masin (Cense bl. 29), waar perawas naast djariangau wordt genoemd als geneesmiddel voor een kind. $-\mathrm{N}$ manimboen iplv. mengimboen, 177/9 id.; nimboen, koet. iets branden, steeds van dingen die veel rook geven, bdj. manimboen id. Vgl. lamp. nimoen, bewieroken, wierook branden. Zie 137/24 menimboen doepa, 189/6 menimboen wédjén. Niet te verwarren met koet. tamboen, zie 190/5. - raoen, $177 / 9$ id., koet. een verzameling blaren en kruiden e.d. om te branden als geneesmiddel, vgl. mal. rabocn. Hierbij 128/27, 177/10 raoenraoenan. $-28 \mathrm{~N}$ als Tnt. 13. $-29 \mathrm{~N}$ mangkin - sin, 177/12 id.; ook $\sin -\sin (129 / 8,177 / 23)=$ mangkin - mangkin $(129 / 7 / 10)$. N spelt

gewoonlijk سين wat wain voorstelt en niet sasin (vgl. $\mathrm{K}$ bij 128/29). Het woord is in de koet. spreektaal niet bekend. Blijkbaar is het een taki-woord, syn. van mangkin, mogelijk ontleend aan het bdj., dat sain naast sagin kent. Tromp houdt het voor een verkorting van samakin (aant. 122). - 30 djoealah is in $\mathrm{N}$ doorgehaald. - demi, 132/14, 164/26 en pass. id., ,gelijk, als" = mal. seperti, thans in het koet. beperkt tot de taki-taal. Het is oud Maleis en komt nog voor in een geschrift van Hamzah Pansoeri (Doorenbos, De geschriften van Hamzah Pansoeri bl.4). In de Tobase tabas-taal heeft domi dezelfde bet. Naast demi vindt men $138 / 30$ v. doemi. Uit demi itoe ontstond koet. demitoe $=$ mal. begitoe, zie 164/2, 167/20 en pass.; de spelling demintoe, die sommige handschriften vertonen (bv. 167, Tnt.7) is naar het bdj. damintoe. VdW geeft dit demitoe als koet. naast het corresponderende demini $=$ mal. begini, bdj. damini. In het tegenwoordige koet. schijnen nog alleen de afgekorte vormen mitoe en mini, meestal vervangen door matjam itoe en matjam ini, in gebruik te zijn. - dibelabar, 177/13 id. Tromp leest dibelabari en geeft in aant. 125 als verklaring ,rondom beschutten van een vrucht als kom. 
kommer met in den grond gestoken takjes tegen vertrappen." In verband met de betekenis van het jav. woord en mal. belebar lijkt mij deze verklaring aannemelijker dan die men mij aarzelend gaf : voorzien van een onderlaag van gras, blaren e.d. om de vrucht tegen onmiddellijk contact met de bodem te beschermen. Vermoedelijk wordt hetzelfde woord ook aangetroffen in Oend. B.N. fasal 56, waar men menempoeh belabar iplv. menempah belaboer zal moeten lezen. - diboemboeni, 177/13 id., Tromp aant. 126 ,van boven met blaren toegedekt tegen de warmte” (lees „zonnehitte”), hetgeen overeenkomt met de mij gegeven verklaring, vgl. mal. - $33 \mathrm{~N}$ berkerdja - menepoeng tawar anaknja, $177 / 17$ id., aan zijn zoon de tepoeng-tawar-ceremonie voltrekken, hem „tepoeng-tawarren".

\section{9}

1 pati, 177/19 id., koet. gevaarlijke periode, periode van grote kwetsbaarheid, vgl. 209/3 kepatian. - 8 langgoeng, 10, 177/23/25 id., taki-syn. van besar. - 9 berbetak, 12, 177/24 id.; N spelt hier maar 12 ب. . Tromp leest bebatak en verklaart in aant. 130: „het hoofdje oplichten, hetgeen het kind moet leeren als het zich reeds kan omkeeren maar nog niet kan zitten.” Mijn zegslieden verklaarden : „op de buik liggend zich voortschuiven." Vgl. koet. mbatas , een boot op de oever trekken, bdj. mambatak id. Bdj. babatak, een boot door ondiep water (over de bodem) schuiven, vgl. sd. sv. batak. - Vóór mangkin besar behoorde mangkin sehari of mangkin semalam te staan (vgl. 177/23). - $11 \mathrm{~N}$ saïn iplv. sin - 13 doedoek entimoen, 177/27 v. id., Tromp aant. 131 ,zitten als een komkommer, dat is : waggelend zitten,” nauwkeuriger: kunnen zitten als men het vasthoudt. De Bandjarezen zeggen volkomen synoniem doedoek biloengka. - 14 N spelt مرغكع voor merangkak, 177/28 id., hetgeen B's lezing merangkang verklaart. - 15 merambit, 177/29 id.; dit woord was mijn helpers niet bekend, doch zij vermoedden, dat hiermee hetzelfde ontwikkelingsstadium werd aangeduid als met het koet. njoesoer pelempang, lett. lopen langs het hekje, dat men in de deur zet om kleine kinderen het verlaten van het huis te beletten, waarvoor men in het bdj. de uitdrukking sasar kandang bezigt. Dit komt ongeveer overeen met Tromp's vertaling van ,merambat”, zoals hij leest: „loopen, zich overal aan vasthoudende." - 
20 koeawa, 178/2, 204/2 v., 255/2 id., kunnen. De koet. spreektaal kent thans nog slechts de vorm kawa. In 't bdj. wordt kazeawa nog veel gebruikt naast kawa (jav.). Merkwaardig is hier de actieve constructie met verzwegen subject en object, evenals $178 / 2$. - $32 \mathrm{~N}$ dipermainkan.

\section{0}

1 berempas; Tromp aant. 134 ,rĕmpas, een inlandsch batonneerspel, te Tenggaroeng zeer geliefd...", volgt een korte beschrijving. De koet. uitspraak is besempas. Het spel is thans nog bij Toendjoengs, Benoea's en Bentians in zwang; Koetainezen nemen er tegenwoordig, voorzover mij bekend is, geen deel aan. Tromp verzuimt te vermelden, dat de spelers behalve door hoofd, armen en handen met doeken in te wikkelen, zich ook beschermen met van rotan gevlochten schilden. De rug blijft gedeeltelijk onbedekt, en het is de kunst daar, gewoonlijk tot bloedens toe, te raken. De lengte der stokken is ongeveer $60 \mathrm{~cm}$, zodat de spelers gedwongen zijn tegen elkaar op te dringen om te kunnen treffen. Witkamp noemt in zijn „Tocht naar den Goenoeng Beratoes (Piek van Balikpapan)", TAG 1925, bl.27, dit spel bekompas naar de Bentianse naam. - $\mathrm{N}$ berkandjar iplv. kandjar, beide vormen komen in afwisseling met elkaar voor, zie 132/20 v., 139/5, 192/5/9. Tromp beschrijft dit soort van dansen in aant. 175 als volgt: „De dansenden loopen achter elkaar, in een enkele rij, ' $t$ zij in een cirkel, ' $t$ zij om iets heen [tegen de zon in, Kern], ieder voor zich de armen bewegende en nette passen makende.... Dikwijls echter laat men deze bewegingen achterwege...." Zie ook aant. 30, bl. 79. Noch bij de Koetainezen, noch bij de Boekits van het Meratoesgebergte, die er plaatselijk verschillende wijzen van dansen onder verstaan is het kandjar een wapendans. Mal. berkandjar wordt dan ook ten onrechte met perz. chandjar, dolk, in verband gebracht (vg1. nog ojav.). 139/32, 140/1 mengandjarkan, laten dansen (een voorwerp). - $6 \mathrm{~N}$ mengira2kan iplv. mengérau-éraukan, evenals in de parallelle passage 178/17. De bedoeling is, dat hij erover zat te denken, bij zichzelf overlegde, hoe hij aan mensen voor de tidjak tanah-ceremonie zou komen, op wier hoofden namelijk het kind zou moeten stappen. $-9 \mathrm{~N}$ als Tnt. 5, doch hierna nogmaals: Demang Djaitan Lajar. - mengajau, 11 id.; het grondwoord is in Koetai ajau, niet kajau (vgl. o.a. Tromp ant. 22). Mengajau is hier transitief en betekent koppen snellen bij, - van; 178/20 v. wordt het intransitief gebruikt. Vgl. ng. manganjau, dat evenzo op beide wijzen wordt gebruikt. - Poelau Semanti? - 11 Poeloe Pandjang, lees Poelau P., 
ligging? Er zijn verschillende eilanden van deze naam. - 12 Poelau Lindoer? - $13 \mathrm{~N}$ mana. - $14 \mathrm{~N}$ als Tnt. 6. - 18 het tweede orang gaat terug op $\mathrm{N}$, waar het in margine is ingevoegd; het juiste woord is natuurlijk kerbau, zoals $\mathrm{T}$ leest. $-\mathrm{N}$ sapi iplv. lemboe. $-19 \mathrm{~N}$ lemboe iplv. sapi. - $\mathrm{N}$ als Tnt. 9. - 20 pajau, koet. hert, br. ser. en verschillende daj. talen id. Het is opvallend, dat het woord slechts éénmaal in deze tekst wordt gevonden, en overal elders het uit jav. of bdj. ontleende mendjangan wordt gebruikt (vgl. 128/1, 170/32). - N dan ontbr. (bis). $-21 \mathrm{~N}$ dan ontbr. $-25 \mathrm{~N}$ dengan iplv. dan; vgl. 179/1, alwaar de goede lezing. - 27 kerdjat madjat, wordt door Tromp in aant. 137 met ,lawaai, drukte" weergegeven, een weinig bevredigende, en voor plaatsen als $165 / 24$ en $244 / 26$ in het geheel niet passende verklaring. De juiste uitspraak is keradjat madjat, zoals $\mathrm{N}$ ook gewoonlijk spelt, en de bet. is te omschrijven met: de volledige voorbereidingen voor een bepaald ceremonieel, het gereedmaken van alle materiaal, dat daarbij te pas moet komen en tevens dat materiaal zelve, en alle handelingen die aan het ceremonieel moeten voorafgaan om dit te doen slagen. Hier en $179 / 2$ wordt gesproken van de k.m. van het tidjaktanah; 165/24, 236/13, 237/31,244/26, 247/24 van die voor een bruiloft (op de eerste aangehaalde plaats bepaaldelijk van alle voorwerpen, waaruit de bruidschat bestaat); 226/12 van de verheffing van een vorst; $186 / 9$ van de dodengebruiken, voorafgaande aan het beëindigen van de rouwperiode. De afleiding is mij onbekend. - 28 Adji. in koet. een algemene titel voor personen van vorstelijke afkomst van beiderlei kunne. Van Adji zonder daaropvolgende naam sprekende bedoelt men er gewoonlijk den Sultan, die ook Adji Soeltan wordt genoemd, mede, tenzij in de kring der familie en volgelingen van iemand van hoge adel, waar men er dezen mee aanduidt. Zo wordt in de Sal. met adji niet alleen de (a.s.) vorst bedoeld (bv. 131/24, 132/3/13/26 en pass.), doch wordt het ook gebruikt voor Poeteri Djoendjoeng Boejah $(138 / 4,161 / 11$, adji poeteri 161/15). Syn. van mal. radja is het woord in $231 / 17$, waar Poentjan Karna de adji van een aantal Toendjoengs wordt genoemd. - $31 \mathrm{~N}$ diemban iplv. diambin, 216/10 id.; jav. ngemban, op de heup dragen in een slendang. Het woord schijnt in de koet. spreektaal niet voor te komen evenmin als dat in Bandjar het geval is met het syn. masamban der bdj. teksten.

\section{1}

1 dipandi, gebaad worden, vgl. 136/4 v. dipandi orang, 167/13 dipan$\operatorname{dinja}=167 / 23$ dimandikannja. Vermoedelijk heeft er oorspronkelijk 
gestaan dipandis $i$, of liever dipendis $i$, naar koet. spraakgebruik: mendi, baden (intr.), mendisi (dipendisi), iemand baden. -4 berpanah-panahan, 136/10 id., elkaar beschieten, namelijk met bamboe waterspuitjes (panah air). Tromp aant. 139 bij deze plaats: „Dit gemeenschappelijke baden is te Koetei nog steeds bij verschillende feestelijkheden in zwang, waarbij de spuitjes nimmer ontbreken." Dit geldt ook voor 1940, behalve dat de spuitjes zijn vervangen door de motorbrandspuit! Onder „baden” versta men hier ,elkander natplenzen op de oever”. De ceremonie, die in de namiddag van de laatste dag van een érau plaats heeft, heet belimboer. -7 dipakainilah, lees dipakaianilah, vgl. 171/9, 192/12. aangekleed worden, van het secundaire grondwoord pakaian. De vorm is koet. en bdj. De vorm dipakaii, die N 251/2 en $\mathrm{K} 171 / 9$ vertonen, is niet gangbaar; in 't mal. zegt men memakaikan. Eigenaardig is, dat $135 / 21,171 / 19$, 251/8 memakai en 166/32, 167/9 memakai-makai ,zich kleden" betekent, evenals menganggo (131/18). - kampoeh, 160/11, 169/15 en pass. id., jav. k.i. bij dodot. - poléng bang bintocloe adji, 160/11 en pass. id. (168/9 ontbr. bang). Bintoeloe is volgens GR „bontgeruit van een kleed .... met 4 kleuren, rood, geel, wit en zwart, zooals de dodot van Bima." Vgl. Moens, Een Jogjasche wichelplank, Djåwå 19 (1939), bl. 8: „Bima's vierkleurige beenkleed heet „Polèng bang bintulu"." Vgl. verder J. en P. III, 55 polèng bintoeloe adji, ,een motiefje van kwadraten", polèng bang binantoeloe in KBW sv. bintoeloe, en Irawan Rabi 30/6 v. polèng bang bintoeloe adi (sic). Is de overeenkomst van bintoeloe met de naam van een rivier en landstreek in Serawak toevallig? Volgens de vorige Ranee of Sarawak, My life in Sarawak p. 146, vervaardigen de aldaar wonende Milanaus geruite katoenen kains. De kleuren schijnen echter slechts zwart en wit te zijn. $-8 \mathrm{v}$. jang tempatnja beroeloer ( $\mathrm{N}$ basoeloer), waaraan neerhing; na deze woorden zou ik kaloeng iplv. itoe berkaloeng willen lezen. 9 kaloeng bantolo, 171/11, 192/14 id.; volgens Tromp aant. 144 ,halssieraad, bestaande uit drie gouden platen hangende beneden elkaar aan een gouden keten." Bantolo is jav. bantåla, dat naar het schijnt een motief in goudwerk of een bepaald soort van goudwerk aanduidt, vgl. GR tjarita boentala sv. boentala; bintala bij J. en P. IV, 127 en KBW sv. bantala : pinggel kana bantala. -10 het eerste bergelang is in $\mathrm{N}$ doorgehaald, met een weinig duidelijke streep. - tengkang, 136/28, 171,12 en pass., Tromp aant. 145 ,bracelet aan den bovenarm”, koet. 11 bersoesoemping, t.r. bersoemping (B's lezing vindt haar oorzaak in geknoei bij N, evenals I's bersemoe soemping!), zoals 160/19, 169/17 en pass. De geredupliceerde vorm, die in 't bdj. burgerrecht heeft ver- 
kregen (sasoemping) wordt overigens ook in 't jav. aangetroffen (soesoemping). - gadjah ngoeling, vgl. 171/12 g. angoeling (dit ook te lezen 192, noot 4); jav. g. ngoling (GR, Irawan Rabi 36/8, Bab natah bl. 20 met afb.), doch ook g. ngoeling (J. en P. IV, 126 en GR sv. gadjah: ,gadjah ngoeli”). - 12 geloeng kelingan, 144/27, 160/15 v. en pass. id., jav. soort van haarwrong. - tjoetjoek geloeng, 144/28 en pass. id., vgl. mal. tjoetjoek sanggoel en jav. tjoetjoek mentoel naast toesoek m., toesoek kondé e.d. (J. en P. IV, 145), bdj. tjoetjoek kondé. Hier doet steeds een kris als haarwrongspeld dienst, vgl. vooral ook $154 / 22$ en $160 / 15$. Dit gebruik is thans te Tenggarong onbekend. Misschien is het een mythische trek, die in de verte herinnert aan het gebruik van de kris Si Gendjé, het Djambische rijkssieraad volgens de legende, vgl. TBG 48 (1906), bl.121. 13 bomawidjaja, 144/28, 171/14, 192/16 id.; Tromp aant. 150 „,bomowidjodjo $=$ naam van een krisgevest in den vorm van een wajangpop, voorstellende Bomowidjojo." Vgl. 251/6 Boma menerkam. Krisheften in de vorm van wajangfiguren zijn vooral van Bali bekend (zie J. en P. $\mathrm{V}, 229$ ). - penampoek geloeng; Tromp aant. 151 ,pěnampoe = gouden versiersel onder de haarwrong." Het is blijkbaar syn. van tamboek geloeng, 171/15, 192/16, die eveneens de vorm van de garoeda moengkoer heeft. Vgl. snd. tapoek geloeng in Tjioeng Wanara, ed. Pleyte, b1. 90. - 14 goerda moengkoer, 171/15, 192/17, 226/6 id.; jav. garoeda moengkoer, het bekende hoofdsieraad. - beroerap-oerap, 144/29, $160 / 18$ en pass. id.; N spelt gewoonlijk beroerab ${ }^{2}$ als B in 169/18, 171/15. Jav. oerab-oerab of oerap-oerap betekent volgens GR ,iets dat met iets anders, ook met welriekende olie, gemengd wordt of iets dat er op gestrooid wordt." KBW geeft het weer met wedak. Dit laatste is ook de bet. in Tenggarong. Vgl. Tromp's aant. bij djajang seteroe hieronder. Soorten van oerap-oerap in de Sal. zijn behalve de laatstgenoemde: djajang sari, djajang katon (sidjajéng katon), halambak masak (251/6) en parang roesak (160/18). Deze namen doelen op de samenstelling van het smeersel, en misschien soms ook wel op de wijze, waarop het geappliceerd wordt (zie hieronder en aant. bij 160/18). De oerap-oerap is welriekend blijkens 160/19: baoenja semerbak teroes kedaton, doch de door Wilkinson in zijn definitie van mal. oerap ("Cosmetic lotion; scent; wash rubbed on the body for fragrance but not for colouring") gemaakte restrictie gaat voor het verdubbelde woord, althans in Koetai, niet op. Wilkinson schijnt beroerap-ocrap direct van mal. oerap af te willen leiden, wat niet juist is. Het gaat terug op het jav. leenwoord oerap-oerap, ook al komt dit in de litteratuur 
misschien niet zelfstandig voor. Evenzo leide men beroerapan en beroerap-oerapan af van de secundaire grondwoorden oerapan en oerapoerapan. — djajang seteroe, 171/16, 192/17 id., zou eigenlijk djajéng s. moeten zijn, doch de mal. uitspraak is vaak djajang, evenals in bdj. sjacirs, waar djajang zelfs als syn. van $d j$. s. als rijmwoord is aangetroffen. Tromp aant. 153 ,naam van een geel smeersel, aangebracht zooals te zien is op de armen van den Kroonprins van Koetei (zie afbeelding.) Deze versiering is een vorstelijk distinctief." De benaming wordt thans in Tenggarong niet meer gebezigd. 201/12 vindt men een oerap-oerap djajang sari, dat blijkens opgave van Klinkert ook in Mésa Kagoengan (zonder oerap-oerap?) voorkomt. Terwijl deze namen voor de jav. litteratuur niet ,belegt" schijnen te zijn, is dat wel het geval met djajéng katong, naam van een smeersel (KBW), een soort van welriekende olie (GR), dat wij hier als onderdeel van de naam van een oerap-oerap terugvinden in de vorm djajang katon (160/18) en sidjajéng katon (169/18, dus hier goed gespeld). Vgl. oerap-oerap sari djajéng katon (lees si iplv. sari?) in Hik. Indra Bangsawan, bl. 48 en minjak sidjajang katon, voorkomend als toiletartikel in de Kroniek van Bandjermasin, maar ook in de bdj. volksoverlevering als naam van een toverkrachtige olie bekend. Tenslotte geeft $137 / 1$, waarschijnlijk abusievelijk, sidjajang zonder meer. - 15 kenaka, 171/16, 192/18 id.; Tromp aant. 154 „kruisje van goudpoeder, waarmee eenige kleefstof is gemengd (zie afbeelding van den Kroonprins; behalve in het gezicht zijn op den rug aan weerszijden zeven kěnaka's aangebracht) kěnaka is ook een vorstelijk distinctief." Tegenwoordig kent men slechts de twee kruisjes op het gelaat. Op de rug worden wel bepaalde figuren van goudstof aangebracht, doch deze heten teraté. Ofschoon men bij voorkeur kenòkò zegt te Tenggarong, schijnt het woord in deze speciale bet. niet jav. te zijn. - bersipat alit, 171/16, 192/18, 206/21 v.; de juiste bet. wordt mij uit de woordenboeken niet duidelijk. Voor sipat vgl. jav. "oogsmeersel of oogwater" (cf. sipat mata bij vdW en Wilk.), voor alit vgl. de woordenboeken. Een mijner helpers wilde hier alis lezen, wat ook in Hik. Indra Bangsawan, bl. 48 wordt gevonden. - 16 tinatah tinatoerangga (naar spelling $\mathrm{N}$, als B 171/17, 192/19), vgl. de jav. woordenboeken sv. tatah en tatoer; keris tinatah zou dan betekenen „een van onderen aan het lemmer met bloem- of lofwerk uitgebeitelde en met goud ingelegde kris", terwijl tinatoer rengga misschien zou betekenen rinengga ing tatoer (tatoer $=$ gedegen goud) (GR). Inmiddels wordt in jav. hss. meermalen de spelling tinatoerangga aangetroffen. tjoela semoeng, 192/19 id.; vgl. 171/17 samoeng. Misschien is dit een 
syn. van jav. toenggak semi, waarnaast tjoela semi wordt aangetroffen, bv. in hs. Bat. Gen. 295, LXXIV, 24: keris paroeng pendok silih asih, abagoes jèn tinon, pan oekiran tjoela seminé en ib. LXXXVI,15 adoezooeng tinatoerangga, oekiran tjoela sinemi. - 18 menganggo, 171/19, $192 / 21$; jav. nganggo, dragen van kleren, hier blijkbaar gebruikt als een hoog woord voor memakai, zich kleden (vgl. aant. 131/7). - 19 didalam, uit de vorstelijke woning. - pajoeng bawat, Tromp aant. 160 „klein [e pajoeng] met een daarover hangend netwerk van gekleurde koorden, eindigende in kwasten", vgl. de jav. en mal. woordenboeken. Naast deze noemt Tromp nog de pajoeng agoeng (131/21, 135/25/27, $136 / 20)$ en de pajoeng oeboer-oeboer (136/20). Tegenwoordig gebruikt men de laatste alleen bij vorstelijke begrafenissen, terwijl bij andere plechtigheden de z.g. pajoeng oemboel-ocmboel te pas komt. - $\mathrm{N}$ kendaga iplv. gendaga; de door Tromp in aant. 158 gegeven verkiaring berust blijkbaar op de woordenboeken en niet op eigen aanschouwing, daar de onder de koet. oepatjara's voorkomende gendaga een zilveren doos is, in de vorm van een ronde schaal met deksel. - lantai, lees lanté, 192/22 id., waaronder hier verstaan wordt een lange, cylindervormige doos van zilver, dus geheel anders dan aan de jav. hoven. Gendaga (of kendaga) lanté is ook de titel van een soort van kratonambtenaren op Java; men vindt hen in de Sal. genoemd aan het hof van het z.g. Madjapait, 200/12/15/18/22. - N als Tnt. 13; kasoer baboet, 192/22, 228/7, 229/22 id.; hiermee is waarschijnlijk één voorwerp bedoeld, doch de naam is thans niet meer bekend. Vgl. jav. baboet, ,tapijt, vloerkleed, sprei van een matras." Kasoer baboet wordt ook aangetroffen in Irawan Rabi 6, 7, doch, zoals Dr. Tjan Tjoe Siem zo vriendelijk was mij mede te delen, is dit de enige plaats in de jav. litteratuur, en vindt men in verwante passages elders slechts baboet. 21 pepangkoean, 137/5/17, 193/5 id., doch meestal gespeld „pepangkoen", als $132 / 1$ v., $137 / 19$ en pass., wisselt in de tekst af met de ongeredupliceerde vorm "pangkoean”, 135/23, 191/17 v. Tromp spelt pepangkoen, maar de juiste uitspraak is pepangkon, waarvoor tegenwoordig alleen de ongeredupliceerde vorm pangkon in gebruik is. Over dit woord merkt Tromp in aant. 159 op: „Pĕpangkoen, eigenlijk Pepangkoean $=$ wat op den schoot gedragen wordt [vgl. 135/24 ... dengan orang jang memangkoenja]. Men heeft twee soorten van pěpangkoen : p. dalam (binnen) [131/21 en pass.; 191/17 pangkon $d$. of p. rěnik (kleine) $[132 / 2,193 / 5]$ en p. loewar (buiten) [191/18 pangkon l.] of p. besar (groote)" [132/1, 193/5]. Volgt een opsomming van de voorwerpen, die ervan deel uitmaken, en wat de betekenis is. 
Pangkon zal wel van jav. oorsprong zijn, al komt het in deze zin niet (meer ?) voor. Pigeaud wijst mij op lara-pangkon, het „schoothoentje”, dat in sommige streken op Java in bruidstoeten wordt meegedragen, en dat door hem in verband werd gebracht met de oepatjara's in de vorm van hoenders aan de jav. hoven (vgl. zijn Javaanse Volksvertoningen § 171). - 23 Gantar, lees Gentar; si Gentar Boemi, 192/25, $193 / 13$ id., is evenals si Sapoe Djagat een geliefde naam voor een kanon. Met si Gentar CAlam van 244/33 zal wel hetzelfde stuk bedoeld zijn. Men zegt, dat dit kanon het thans Djaga Koetai genoemde is, waarvan nog stukjes worden bewaard (vgl. Tromp bl. 102, no. 20). 25 tanggal, lees toenggal, 192/28 id.; koet. petér toenggal, één harde donderslag, min. patoeih toengga id. - 26 diseroedoekinja, 192/29 id., volgens koet. uitspraak diserodo'inja. Tromp aant. 161 ,,sroedoek = onderdoorgaan." Vgl. min. saroedoees, saloedoees $=$ mal. serondong; manjaloedoee $^{s} i=$ mal. menjoeroeki (Kamoes) en Wilk. sv. seroduk. 27 menengah hari, 192/30 id. = tengah hari, r. 25. - 29 léman, 136/23 en pass.; uit Tromp's uitvoerige beschrijving (aant. 30, bl. 78 en ook aant. 163) krijgt men de indruk, dat alleen de twee slangen zo heten. De met zijden stroken in de kleuren van de regenboog omboorde mat, waarop de slangen rusten, behoort er echter ook toe. In het laatste deel van de Sal., nl. 226/33, 229/14 v., 251/14 wordt het voorwerp enige malen tapak léman genoemd. Dit betekent, zoals men weet, Salomonszegel, en is de naam van een bekende magische figuur, doch het werd door den schrijver blijkbaar opgevat als een fraaie uitbreiding van léman. Wat de afleiding van dit woord betreft, Pigeaud wijst mij op de mogelijkheid, dat léman teruggaat op jav. liman, olifant, in verband met het bekende complex olifant-naga. - 31 mandargili; $\mathrm{N}$ spelt $138 / 14$ v. mindargili. Tromp aant. 164 ,plaats, waar de Sultan bij het těpoeng-tawar gezegend wordt", en uitvoeriger ib. bl. 78. Hetzelfde is wel bedoeld met balai mandargili, 133/7. Het woord, dat thans niet meer in gebruik is, mag men misschien in verband brengen met jav. mandragini. - 32 berpimpin, 138/15, 193/3 id. zich onder het voortgaan aan iets vasthouden; mimpin van 200/30 heeft de gewone mal. bet. - toentoenan, 138/15, 193/3 id., koet. leuning van touw of rotan, bij noentoen, aan de hand leiden, bdj. manoentoen id. $=$ mal. memimpin. - diperidan, 138/16, 193/3 id., koet. gevlochten, gedraaid, van koord, vgl. Tromp aant. 165. Met emas diperidan is hier bedoeld de tali djoeita, een van goud-, zilver- en roodkoperdraad gevlochten koord (vgl. Tromp bl. 78). 


\section{2}

2 renik, koet. $=$ mal. ketjil, lamp. id.; hier en pass. van pepangkon gezegd; van mensen : $134 / 16$ renik besar toea moeda, 174/8 v. kekanak renik, enz.; van het hart: $216 / 7$ renik hati. B heeft op de laatste plaats en 170/2, 226/15 renik door ketjil vervangen. - $3 \mathrm{~N}$ ampar iplv. (h)amparan, blijkbaar geen vergissing, want $171 / 25$ wordt dezelfde lezing gevonden, 193/6 echter weer amparan. - diatoeri, werd uitgenodigd. Het van oorsprong jav. atoer en afleidingen, met de grondbetekenis "hetgeen men eerbiedig richt tot een hoogergeplaatste" (Berg, Bijdr. Jav. Werkwoorden, bl. 230), wordt in de Sal. zeer veel aangetroffen. Het heeft in het koet. evenals in het bdj. volkomen burgerrecht verkregen. Voorbeelden van het gebruik uit de Sal.: 159/21, 160/7 en pass. atoer, eerbiedige mededeling. 158/31, 198/14 en pass. mengatoer, eerbiedig mededeling doen, eerbiedig spreken, teruggaande op jav. matoer (opgevat als me-atoer), welk woord $158 / 5$ en $179 / 21$ wordt aangetroffen. Mengatoerkan, a) iets eerbiedig aanbieden, aanreiken: 214/26 (di- 153/12, 200/3, 201/19), b) iets eerbiedig mededelen: $198 / 14 / 17$ en pass. ( $d i-143 / 2,158 / 22$ en pass.) $=$ mal. mempersembahkan. Mengatoeri, iemand eerbiedig uitnodigen: 133/2, 183/6, 235/33 $($ di $-132 / 3,256 / 34)=$ mal. mempersilakan. Alleen $234 / 28$ betekent deze vorm : iets aanbieden aan een hogergeplaatste. Het suff. $-i$ drukt hier echter waarschijnlijk de meervoudigheid van het subject of het frequente der handeling uit. De bij atoer en afleidingen gebruikte praepositie is gewoonlijk ke of kepada; vóór andika wordt echter ook di gebezigd: 159/21 itoelah atoer patik diandika; 158/31 patik mengatoer dahoeloe diandika. $137 / 17 \mathrm{v}$. treedt mengatoer in de gewone mal. bet. op. - 5 pondongan, 10, 138/21/26 id. Tromp aant. 166 „toekangpondongan, moet iemand beteekenen, die een vorstelijk personage met vertelsels bezighoudt, waarbij deze allerlei lieve, mooie namen gegeven worden," en hij vertaalt r. 9 v. maka poepoeslah pondongan oléh si Loemadjang oléh si Loemakoe, met ,waren Si-L. en Si-L. met vertellen klaar." Erg overtuigend klinkt deze verklaring niet, en klaarblijkelijk wist Tromp's commentator evenmin raad met het woord als de mijne. Hs. N wijst ons echter de weg. Overal waar Tromp pondongan heeft, spelt dit hs. namelijk فندؤثَز , wat op de uitspraak pendaoengan wijst. Van het onbekende grondwoord daoeng vinden wij 139/1 en 173/32 de afleiding berdaoeng, waarvoor B berdaboeng geeft. Ongetwijfeld is dit daoeng (of daong) hetzelfde als mal. daboeng (vgl. koet. 
maos, saong, raoen, mal. maboek, saboeng, raboen). Toekang pendaoengan is dus hetgeen men tegenwoordig in koet. toekang rasah, tandenvijler noemt, berdaoeng i.q. huidig koet. berasah. In r. 10 betekent pendaoengan het tandenvijlen. - 6 tjetjorong, 138/23 id.; dit woord, door vdW sv. tjorong IV vermeld (naar Leydekker) met de bet. „draaibas, kamerstuk", mist men in de nieuwere woordenboeken, tenzij tjetjerong bij Klinkert en tjetjérong bij Wilk. op een schrijffout hiervan teruggaan. Vgl. nog Cense, De kroniek van Bandjarmasin, bl. 20 bedil tjetjorong (t.o. met ,geweren” vertaald), Hik. Radja Atjéh (Ms. Or.

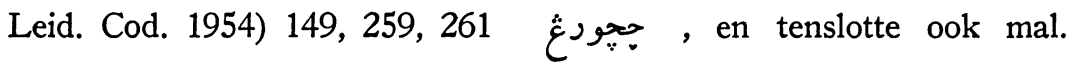
setjorong. -7 kota tjoendoeng, wel te lezen $k$. tjondong, 138/23 id. Wat dit voor een soort bolwerk is geweest is thans te Tenggarong niet meer bekend. - $\mathrm{N}$ rantjas soedji iplv. rantja s., 138/23 id. Blijkens een aantekening in Tromp's oorspronkelijk afschrift zou het de naam van een pagar zijn, gelijk wordt meegedeeld door Cense, De kroniek van Bandjarmasin, bl. 144, noot 2, naar aanleiding van het voorkomen van dit woord in die kroniek. Cense vergelijkt hiermee jav. wantjak s. of pantjak s. -8 angar angin, 138/25 angarangin; Tromp aant. 167 ,angěrangin = zacht en langzaam." Het is jav. ngrangin of ngrerangin, ,zich zacht en aangenaam (op een afstand) laten hooren van muziek of gezang" (GR), waarvoor sommige ojav. teksten angarangin of mangarangin hebben (KBW sv. arangin). Vermoedelijk wordt dit ook bedoeld in de Hik. Radja-radja Pasai, 100/19: segala boenji-boenjian

(اغرادغن (angrarangin?) boenjinja, waarvoor Mead in JSBRAS 66, bl. 51 ingar-ingaran leest (overgenomen door Wilk. sv. ingar). 9 lawas, 196/17, 232/16 id., in koet. en bdj. algemeen in gebruik iplv. mal. lama (jav.). - $10 \mathrm{~N}$ pendaoengan iplv. pondongan - Loemadjang, N spelt naam: sampoenlah pendaoengan behoort te worden ingevoegd. Wij hebben hier weer een stukje taki voor ons, en maken daaruit op, dat met si Loemadjang en si Loemakoe niet twee, doch een en dezelfde persoon is bedoeld, en wel de toekang pendaoengan. Wat de aanleiding tot deze eigenaardige betiteling met jav. woorden voor ,lopen” is, kan ik in de verste verte niet gissen. - 10-13 bevat nog een aantal technische termen betreffende het tandenvijlen, waarvan Tromp reeds geen goede verklaring meer kon verkrijgen ter plaatse. Misschien dat een vergelijking met beschrijvingen van methoden van tandmutilatie in 
streken, waar ze nog in zwang is, hierin nog enig licht zal kunnen brengen. - 10 sebintir, vgl. 138/27; bintir is koet. hulptelwoord, in het bijzonder voor lange, buigzame voorwerpen als haren, draden, rotanstengels e.d. - 11 waloe, 138/27 id., koet. en bdj. = mal. delapan; evenals pitoe, zeven, dat ook in beide dialecten voorkomt, en teloe (zie 160/14) behoort het waarschijnlijk tot de oude mal. taalschat, en is het geen leenwoord. - sebintir, $\mathrm{N}$ spelt sebitir, men leze sebilah met 138/27. - dibantjar toedjoeh, volgens Tromp aant. 169 in zevenen gekloofd; bantjar, of bentjar, dat mijn helpers niet bekend was, doet hier dienst als taki-syn. van belah. Vgl. bdj. bantjar, gescheurd, gebarsten, van de schedel; van de loop van kanon of geweer, plaatselijk ook van glas en aardewerk, en mal. boenji bentjar, ,een geluid als van eene gescheurde klok of van gebarsten porselein" (vdW). - lakoe, zoals? - menjirip lais, ,als de vinnen van de lais". - 12 goorindjam, $138 / 28$ id. Tromp geeft het weer met polijsten, mijn zegslieden vermoedden, dat het een syn. van ragam was; volgens Wilkinson is gerindjam "pointed stone for filing the teeth"; wat hier precies is bedoeld is mij niet duidelijk. - mangkin, 138/28 leest giginja. - 13 poentjak reboeng, 138/28 id., koet. het tandvlees, blijkbaar eigenlijk hetzelfde als mal. poetjoek reboeng, algemene benaming voor versieringsmotieven in de vorm van een rij puntige, gelijkbenige driehoeken; ook voor br. "puchok rabong" wordt de bet. tandvlees opgegeven (Haynes). - 14 gantén, 138/30 id., Tromp aant. 172 „bloed; wegens de overeenkomst van sirihspuw met bloed wordt gantěn (sic) ook voor sirih gebruikt." Het is echter eerder een onmiddellijk leenwoord uit het jav., k.i. bij kinang, sirihpruim. - beroendja-roendja, door Tromp aant. 173 weergegeven met ,heen en weêr loopen"; volgens mijn helpers is het woord te Tenggarong niet bekend, doch zou het dialectisch elders voorkomen in de zin van ,huppelen". De bedoeling van het rennen van het pinangsap en het huppelen van het sirihvocht is volgens mijn helpers inderdaad, dat het rode speeksel ,niet aan de tanden hechtte" (Tromp's vertaling) door de gladheid der tanden. - 18 selangkap tiang, 139/3 id., bij elke stijl, zoals door Tromp juist wordt vertaald (algemeen mal. spraakgebruik?) ; vgl. 227/21 langkap balai, waar men se-node mist. - $21 \mathrm{~N}$ bini- $25 \mathrm{~N}$ pepandén petola iplv. $p$. petolo, $135 / 2,139 / 10$ id.; een beschrijving van dit voorwerp geeft Tromp aant. 176. Tegenwoordig noemt men het tiang pandén. Voor jav. papandèn wordt als bet. opgegeven rontèk, lalajoe, piek met een vlaggetje; petola, of javaniserend petolò is jav. patola, een veelkleurige zijden stof. Over het ivoren schaakspel, ook door Tromp in genoemde 
aantekening vermeld, vermocht $\mathrm{ik}$ geen nadere inlichtingen te verkrijgen. - $27 \mathrm{~N}$ érau iplv. iraunja; Adjipoen mengantokkan (N مثنتؤكن ) érau, Adji menjoedahkan sawat. Tromp, die deze passage door ajar wadji iplv. érau adji te lezen geheel verknoeit, geeft niettemin in aant. 177 op, dat mengantokkan hetzelfde als menjoedahkan moet betekenen. Het woord is mijn helpers onbekend. Vergelijk misschien jav. entok $=$ entèk en ngentok, tot het einde gekomen? Saruat, even onbekend, moet ongeveer syn. met érau wezen. Dat het de naam van een spijs zou zijn, naar Tromp veronderstelt, is al heel onwaarschijnlijk. 28 egoeng goeloeng, 179/11 en pass. id., Tromp aant. 178 ,paloe gonggoeloeng $=$ rommelend slaan van de gong". De koet. uitspraak is gong golong, waarmee wordt aangeduid het zonder het volgen van een bepaalde lagoe willekeurig door elkander spelen van alle gamelan-instrumenten, nog steeds in gebruik ten teken van het beëindigen van het érau, vgl. 193/31 maka berboenjilah egong golong tandanja kerdja radja soedah berhenti. $-29 \mathrm{~N}$ als Tnt. $11-\mathrm{N}$ dipetjaramkan iplv. dipentjarakan, 139/11 id. Mijn zegslieden kenden het woord niet, evenmin als dipantjarakan van Tromp, wat deze in aant. 180 vertaalt met „,te gelijker tijd bespelen”. Deze vertaling kan ook gelden voor de ongetwijfeld juiste lezing dipetjaramkan, wat blijkbaar een taki-synoniem is van dipebajakan. Men vergelijke behalve jav. tjarem, dat een enigszins gespecialiseerde bet. heeft (zie ook KBW), bdj. batjaram, gezamenlijk (iets doen), md.-mal. tjaram-tjaram, gelijktijdig, tegelijkertijd, en ook tjaram, geweeklaag, gejammer en geween in een sterfhuis, wat immers voluit tjaram tangis heet. -32 njioer; Bnt. 12 in slaafse navolging van N's schrijffout ,menga njajoer". -- N peridjas iplv. peridja, 139/14 id., koet. = mal. kemiri. - keliki, 139/15 id., Tromp aant. 182 "= djarak (Ricinus communis)". Het is boeg. en in het huidige koet. onbekend. - Het "doen vechten" van allerlei dieren, noten e.d. (vgl. ook 139/12-16) is tot besluit van bepaalde soorten van érau's nog in zwang. - melénggang papan, hieronder te verstaan: schommelen op een in het water drijvende plank of balk, hetgeen geschiedt door twee personen, net zolang tot zij tot vreugde van het publiek hun evenwicht verliezen; met melénggang 139/15 wordt natuurlijk hetzelfde bedoeld. - $33 \mathrm{~N}$ besoeras iplv. bersoeara (vgl. Tnt. 14).

\section{3}

$1 \mathrm{~N}$. تري iplv. b. toeria, wat moeilijk anders dan met Tromp als beteri gelezen kan worden. Tromp verklaart het in aant. $183,=$ běsoe- 
$r a k=$ juichen." Het woord is geen huidig koet., men zegt daar beteria's. Vgl. nog 193/14 dengan sorak terinja (N tarinja). Dat mal. tari niet bedoeld is, is duidelijk. Blijkbaar is het een taki-syn. van sorak. Misschien in verband te brengen met ojav. atri schreeuwen? $-3 \mathrm{v}$. oelas boemi, 136/24 id. en oelas balai, de katoenen bedekking en bekleding van de grond en de balais, die na afloop van het érau, zoals hier beschreven staat, onder armen en behoeftigen worden uitgedeeld (vgl. Tromp aant. 184). - $4 \mathrm{~N}$ baloe dan kepada orang na orang. 5 piasan, 168/30 id.; Tromp aant. 185 ,eigenlijk „pěrhijasan” = versiersel, pijasi $=$ ook: kleeden", liever uitdossen, vgl. 136/26, 245/17 dipiasi (van bruid en bruidegom). Het is geen koet. De mogelijkheid bestaat, dat men dipajasi (met T 245/17) en pajasan moet lezen (vgl.

bal. en sas.) - $\mathrm{N}$ spelt overal ج.ج , blijkbaar djinis (I meermalen, o.a. 201/26 ( ) iplv. djenis; deze uitspraak is te Tenggarong thans echter niet bekend. $-6 \mathrm{vv}$. Over de betekenis dezer balais geeft Tromp bl. 88 enige ophelderingen, waaruit o.a. blijkt, dat die met diernamen (b. mendjangan, $b$. boeroeng, (b.) matjan) van bamboe gemaakte dierfiguren zijn, terwijl hij van de „balai teratei” (de koet. uitspr. is teraté) een beschrijving geeft. Hoe een balai memoeloe, of $b$. moemoela $(135 / 2)$ eruit ziet, kon ik niet te weten komen. Galestin wees mij destijds op het Cheribonse mamolo, topstuk van een balai (vgl. zijn dissertatie bl. 222), doch het betreft hier vermoedelijk een geheel ander soort balai. Even duister is mij N's هانتي met onduidelijk geschreven eerste letter (vgl. Bnt. 4). - 9 Oengkal? - Kenangan? - 10 Sambira, t.r. Sembéra - N Marangkajoe - $11 \mathrm{~N}$ orang Kenioengan iplv. Kanioengan - 12 Beras Basah, zou de naam van een eilandje in het Boentangse zijn, misschien een der Kerindingan-eilanden? - Pandansari, thans nog bekend als de naam van een wijk van Balikpapan. — Goenoeng Kemoening? - 13 Ridjang? - N Rigang iplv. Rikang? - Tandjoeng Semat, zou tussen Santan en Marangkajoe liggen. 17 poelang keboemi astananja; deze term verwacht men niet voor onvorstelijke personen. Klinkert vertaalt boemi astana met ,land en paleis, voor plaats waar een Vorst thuis behoort, zijn vaderland", doch Wilkinson (sv. istana) geeft slechts „,homeland, native land”. - N pikirlah 18 didalam hatinja, 139/26, 178/19 id., vgl. 163/14 maka didalam hati Adji itoe. (Di)dalam hati(-koe, -nja e.d.) is in koet. en bdj. een zeer gebruikelijke uitdrukking voor dacht (ik, - hij e.d.), in de bdj. spreek- 
taal vaak afgekort tot damhati. $-23 \mathrm{~N}$ als Tnt. $10-26$ permata benoea, 139/22, 238/13 id.; Tromp vertaalt het thans niet meer gangbare woord met „hoofden”; syn. is blijkbaar permata negeri, 238/20/35. Misschien mag men het weergeven met „notabelen”. Benoea heeft in de Sal. een even ruime bet. als zijn syn. negeri, variërend tussen dorp, landstreek en land, vgl. o.a. 134/11/15, 135/6 en pass. Benoea Koetai $(235 / 27)=$ negeri Koetai $(188 / 33)$. Ook in 't bdj. wordt het zo gebruikt. In de bdj. litteratuur betekent het verder vaak de bewoonde wereld tegenover de wildernis (goenoeng, hoetan), bv. Sj. Hémop 2212: soenggoeh dihoetan didalam rimba, gemoeroeh seperti didalam benoea, vgl. bal. wanzera. De Boekits van het Meratoesgebergte duiden met banoea evenzo het door de Bandjarezen bewoonde gebied, d.i. voor hen de beschaafde wereld, aan. - N Benaloe - 27 Penjoeangan, waarschijnlijk te lezen Penjawangan als 186/13, ligging? - Senawan, misschien $=$ Sendawan, een zijrivier van de Sabentoeloeng. $-28 \mathrm{~N}$

iplv. Sanga-sangaan, dus Sangsangan als 186/14. Waarschijnlijk is hier wel het tegenwoordige Sanga-sanga mee bedoeld. Kembang; in de Moeara Djawa bevindt zich een Poelau Kembang. 29 Soengai Samir? - Doendang; op de kaart bij Witkamp's artikel „Langs de Mahakam” (TAG 1932, bl. 30-65) vindt men de naam S. Dondang voor de waterarm tussen Soengai Tiram en Moeara Djawa. - $30 \mathrm{~N}$ iplv. Semboeni, ligging? - Soesoeran Dagang? vgl. 231/5 - Tanah Malang?

\section{4}

$1 \mathrm{~N}$ als Tnt. $3-2 \mathrm{~N}$ als Tnt. $4-3 \mathrm{~N}$ als Tnt. $5-4 \mathrm{~N}$ als Tnt. 6 - 8 kemarian; koet. kemerian, gewoonlijk merian, namiddag, mal. petang, soré, bdj. kamarian. - bertengar ; Tromp aant. 188 ,těngar $=$ alle instrumenten tegelijk bespelen, zooals gedaan wordt tot inleiding van een feest, hetgeen dan het sein is voor degenen, die tegenwoordig willen of moeten wezen, om op te komen"; of Tromp's definitie van het sein geheel juist is, wist men mij niet precies mee te delen. Naast bertengar vindt men 135/3 batetengar. 137/19 berboenjilah tengar; $\mathrm{T}$ geeft hier tengaran, wat 211/15 alle handschriften hebben. Vgl. jav. tenger, tetenger, sein, teken. - 9 kelintangan, lees keléntangan, koet. een slaginstrument bestaande uit een stel van vijf bonangachtige gongs, op een rij rustend in een houten bak. Het is ook bij verschillende Dajak- 
stammen in gebruik, doch als mijn oor mij niet bedriegt is de stemming daar anders dan in Tenggarong, waar ze bij de gamelanstemming (sléndro) is aangepast. - 10 tiga belas benoea; het totaal der 133/26-31 opgesomde plaatsen is inderdaad dertien. Op r. 15 wordt gesproken van doea poeloeh negeri. Welke hier bedoeld zijn is niet duidelijk, evenmin als dat het geval is met sebelas negeri van 186/21, 187/17 en de tien kampongs van 225/6 (sepoeloeh benoea; 229/3, 232/29 sepoeloeh negeri; $238 / 13$ permata benoea jang sepoeloeh; $238 / 35$ permata negeri jang sepoeloeh). Waarschijnlijk zijn het alle groepen van kampongs, welker bewoners evenals die der thans onder de naam Magarsari begrepen kampongs (zie Tromp bl. 19) bepaalde plichten en rechten t.o.v. de kraton hadden. - 11 soemba, Tromp aant. 190 ,toeschouwen, toekijken", het koet. woord voor nontonnen. - Poelau Atas, aan de linkeroever der Mahakam gelegen tegenover het enige kilometers benedenstrooms van Samarinda liggende Pelaran (,Pelarang”). - $12 \mathrm{~N}$ Karangasan de eigenlijke naam van de even boven Samarinda gelegen kampong, tegenwoordig of ficiëel inderdaad Karang Asam genoemd. - Karamoemoes, volgens de koet. uitspraak. Het riviertje en de aan zijn monding gelegen kampong, thans een deel van Samarinda, heet nu officiëel Karangmoemoes. - 13 Loeah Bakoeng, lees Loah B., gelegen even benedenstrooms van Loah Boeah aan de linkeroever van de Mahakam. Het in veel koet. plaatsnamen voorkomende loah, in Europese bronnen gewoonlijk loa gespeld, is koet. voor (kleine) zijrivier. Semboejoetan, 186/13 id.? - 14 N Mangkoepalas, zoals de kampong, die thans deel uitmaakt van Samarinda-Seberang, ook heet. - $16 \mathrm{~N}$ bawakannja iplv. bawaannja, op te vatten als bawak-an (voor bawasan). Dezelfde wanspelling ook KV 6. - 18 mengarioes, 135/7 id.; Tromp, aan wiens zegslieden het woord blijkbaar even onbekend was als aan de mijne, leest menggérék, wat dan "slachten" zou moeten betekenen (vgl. zijn aant. 45). Dat is echter boeg. en geen koet. Het is niet bepaald noodzakelijk, dat dit onbekende taki-woord "slachten” betekent, daar men $128 / 3$ in hetzelfde verband menangkap leest. Daarom verdient hier de lezing $*_{m e n}$ gerojos ${ }^{s}$ van het bekende jav. ngrojok, met zijn velen aanvallen, aangrijpen, misschien overweging. - $26 \mathrm{~N} \mathrm{Jang-}$ jo of jangio iplv. Ejang Ajoe - 31 v. egoeng siang ditopéngkan, egoeng malam diwajangkan; egoeng staat hier vermoedelijk voor gamelan, en de betekenis is dan: bij de gamelan overdag werden topéng-dansen uitgevoerd, bij de gamelan 's nachts wajangvoorstellingen gegeven. $34 \mathrm{~N}$ lamanja - berpatjar, vgl. Tromp aant. 192, i.q. mal. berinai of berpatjar inai. 
$1 \mathrm{~N}$ als Tnt. $1-2 \mathrm{~N}$ moemoela iplv. moela-moela $-\mathrm{N}$ petola iplv. petolo. $-3 \mathrm{~N}$ batetengar iplv. bertengar $-4 \mathrm{~N}$ tanda $-13 \mathrm{~N}$ maka makan iplv. makan-makan - 14 lees menemposo - $17 \mathrm{~N}$ jang io iplv. Ejang Ajoe - na Hoeloe (Oeloe) leest N: Doesoen dengan Gadjah Perwata Djaitan Lajar setelah demikian maka Ngabé Oeloe (vgl. Tnt. 8). - $19 \mathrm{~N}$ dioelasilah - 24 tombak pengazinan, Tromp spelt t.o. t. pegarvinan; 227/31 tombak emas pengazeinan. Evenals in jav. zonder bijvoeging van tombak hier 181/23 en 194/20 (kebazeah pengawinan), waar het wordt gebruikt als padoeka, doeli, kaoes en dergelijke woorden om den vorst aan te duiden. $-26 \mathrm{~N}$ selangkap.

\section{6}

$1 \mathrm{~N}$ als Tnt. $1-4$ air toed joeh soengai, ,het water van zeven rivieren, namelijk zeven zijrivieren van de Mahakam" (Tromp aant. 194).Volgens Pangéran Tjokro is de uitdrukking figuurlijk en zijn er zeven soorten water mee bedoeld, nl. air soengai, air laoet, air soemoer, air telaga, air akar, air sampai (koet. bron uit de rots), air Mahakam. (Hierbij zij aangetekend, dat men nooit „soengai Mahakam” zegt, doch meestal Mahakam zonder meer of batangan Mahakam. Het woord ",kali" ter aanduiding van de rivier, dat volgens Witkamp (De Kedang Rantau 34) algemeen zou zijn, wordt slechts ten pleziere van Europeanen gebezigd). - 6 melaboeh, Tromp aant. 195, ,in het water werpen", koet. en bdj. - bantan zou volgens Tromp ib. betekenen: "geheimzinnig middel, door vrouwen klaar gemaakt, bestaande uit verschillende bladeren en kruiden." Volgens een mijner zegslieden wordt er echter een in tweeën gekapte klapper onder verstaan, die men na de helften weer op elkaar gepast te hebben, in 't water werpt. Zo waar als deze klapper niet in zijn oorspronkelijke staat zal terugkeren en zo waar als de bokor niet zal boven komen drijven, zo zal men niet door allerlei ongeluk bezocht worden. $-9 \mathrm{~N}$ bersimboer $2 a n-11$ limar angsana, blijkbaar een limar met angsana-motief. - 18 baris, voor berbaris of dibaris? - gandjoer pandjang bergembala merak; Tromp noemt in aant. 159 als eerste der pepangkon loear de ,toembakgandjoer"; of deze benaming thans nog in gebruik is, heb ik niet kunnen vaststellen. Gembala geeft Tromp in aant. 196 weer met ,afhangend versiersel van statiepieken, 't zij haar, 't zij veeren", vgl. jav. koembala en KBW sv. kambala. Gandjoer, jav. een soort van piek, 
komt ook veel voor in de bdj. litteratuur (in Sj. Hémop moet 2768, bl. 92, nt. 26, 2916 en pass. gandjar hierin verbeterd worden). In Tenggarong verstaat men onder gandjoer zonder meer thans een ongeveer een meter lange stok, versierd met pauwenveren, niet ongelijk een plumeau, waarmee door den Sultan en de Pangérans een dans wordt uitgevoerd tijdens het érau (begandjoer). - 19 tombak poentoeng, volgens Tromp aant. 197 ,korte piek”, nu geheel onbekend.

$\mathrm{N}$ leest فنتخ , wat ook andere lezingen toelaat. Vgl. jav. ponțang, „een beslag van metaal hoepelsgewijs om de steelen van een lans..." (KBW). - 21 berkapitan staat voor berkepitan. - toenggoel, bet. onbekend. In 't jav. en mal. betekent het vaandel, doch het is de vraag, of dat hier wel de bedoeling is. N spelt تל ت kan worden; tanggal agoeng zou men kunnen begrijpen als naam van de pieken met halvemaanvormige versiering, zoals Plaat III bij Tromp te zien geeft. T's lezing tangga is onaannemelijk. - 22 toenggoel; $\mathrm{N}$ las oorspronkelijk het juiste tenggiling, waar een andere hand تغكل doorheen heeft geschreven. - 23 ditoekan tangga, koet. aan het ondereind van de trap (tegenover kepala t., het boveneind). Tromp's lezing toeken en zijn verklaring in aant. 198 zijn fout. In het bp. betekent toekan ,trap”. - $\mathrm{N}$ als Tnt. 13 - maligai, 137/17 en pass. id.; Tromp aant. 199 ,hieronder moet verstaan worden een groote, hooge estrade op de aloen-aloen, waarop het těpoeng-tawar plaats vond." $\mathrm{Zij}$ was dus in zijn tijd al niet meer in gebruik. 26 Poeteri Djoendjoeng Boeih; hier treedt deze naam van Poeteri Karang Melenoe voor het eerst op. De koet. uitspraak is $P . D j$. Boejah; koet. boejah $=$ mal. boeih. Voor het voorkomen van deze naam elders zie Cense, De Kroniek van Bandjarmasin bl. 125. - tapih pasak, Tromp aant. 201 ,tapih-pasa = een overkleedje, bestaande uit afhangende slippen, ongeveer drie vingers breed, samengesteld uit vierkante dunne gouden plaatjes". De koet. uitspraak is tapéh pasas. -27 hitakoesoema; in $\mathrm{N}$ is hier zodanig geknoeid, dat allerlei lezingen behalve de juiste, antakesoema (als $\mathrm{T}$ ), mogelijk zijn. Badjoe antakesoema, dat nog in gebruik is, en gewoonlijk $b$. ontrokesoemo wordt genoemd, wordt door Tromp in aant. 202 aldus beschreven: ,kort jakje van geel satijn, met mouwen tot boven den elleboog, van voren en van achteren met dunne platen geslagen goud versierd." De gouden platen stellen merak mengigal, goerda's en dergelijke voor. Zoals be- 
kend is antakesoema in de jav. en mal. litteratuur de naam voor een vliegbaadje. - penangsat, Tromp aant. 203 „gouden koord om den middel geslagen, om een kleedje op te houden". Het woord is thans niet bekend, het bedoelde voorwerp wordt oebat-oebat genoemd. Waarschijnlijk moet men peningsat van jav. peningset lezen. $-\mathrm{N}$ als Tnt. $16-28 \mathrm{~N}$ berkalat (voor berkelat) iplv. berkilat; Wilkinson geeft kilat bahoe als specifiek jav. vorm, wat natuurlijk onjuist is, Klinkert geeft het als enige vorm. Volgens J. en P. IV, 179 is kilat baoe Borneose uitspraak. Dit is inderdaad koet. en kilat bahoe bdj. $\mathrm{Bij}$ k. b. keloepak (t.r. kelopak) hoedang ( $\mathrm{N}$ oedang) tekent Tromp aan (204): „een gouden schouderbedekking [lees bovenarmband, $\mathrm{K}$.$] in den vorm (van) een garnalenschaal (zie portret Kroonprin-$ ses)." - 29 soebang bapang, ,groote oorknoppen" (Tromp aant. 205), jav. soeweng bapang. - naga kepoelir ( $\mathrm{N}$ kapoelir), 206/21 id., als naam van een soemping mij niet van elders bekend. Naga mengoelir van Tnt. 18 is een twijfelachtige ,verbetering”. - 30 peri kinantan, als naam van een geloeng mij niet bekend, Tromp's conjectuur peri siantěn evenmin. - soen gaat terug op een schrijffout van $\mathrm{N}$ en moet vervallen. - 31 tjatjoendoek, 168/10, 206/20 id., Tromp aant. 208 ,tjatjoendoe $=$ haarspeld." De bet. is echter ruimer: op alle drie plaatsen is sprake van een bloem. Jav. tjoendoek ,wat op het hoofd of in het haar gestoken wordt tot sieraad, bv. een bloem of kam of haarnaald", vgl. bal. tjoetjoendoek, mad. (tjo)tjonḍhoek. - anggrék medjati, 201/11 id.; koet. a. medjeti, een kleine, witte orchideesoort (vgl. Tromp aant. 209). - kebang, door B trouw van $\mathrm{N}$ overgenomen. - 32 binaloe, 168/11 id. ( $\mathrm{N}$ benaloe), de alg. mal. benaming voor Loranthus sp. (epiphyten) en niet ,een boom met gelen bloesem” als Tromp aant. 210 wil. - $\mathrm{N}$ boelan temanggal iplv. b. tanggal; van jav. remboelan temanggal, wassende maan.

\section{7}

1 djenoe, Tromp aant. 212 ,moesje boven den neus tusschen de wenkbrauwen.... een vorstelijk distinctief." Vgl. Oend. B.N. fasal 70, r. 14. 't Ojav. woord heeft de ruimere bet. van boréh en wedak. Djenoe antasari geeft Tromp (antaksari spelt hij) weer met ,een geel moesje". Het is mogelijk, dat met antasari hier een mooi woord voor geel is bedoeld, misschien via (badjoe) antakesoema, maar het is zeker niet ,veelkleurig gebloemd," als Mees geeft! - sidja jang, lees sidjajang, waarna vermoedelijk katon of seteroe moet worden inge- 
voegd. -2 kering tilam, $210 / 26$ id., $\mathrm{N}$ karing tilam evenals 160/18; Tromp aant. 213 vermoedt, dat dit moet aantonen, „dat de matras daarvan niet nat werd". Pigeaud oppert de mogelijkheid, dat het een verbastering van een jav. *sekaring tilam is. - koening mengembang baroe, 144/26 id., geel als baroe-bloemen, nl. lichtgeel, de vorstelijke kleur; vgl. 168/9 koening kembang baroe. Misschien is ook te denken aan de in het jav. kembang waroe genaamde kembangan-doeken, die een paarse rand vertonen om een geel midden (J. en P. III, 236, no. 36). - 10 penampa, 20,156/35 id., koet. opvatting, mening, jav. id., mal. tampa: $-11 \mathrm{~N}$ ladjoe iplv. laloe. $-13 \mathrm{~N}$ ampoeni $-15 \mathrm{~N}$ als Tnt. $4-16 \mathrm{~N}$ toeroenlah $-\mathrm{N}$ jang Baboe $D j .-22 \mathrm{~N}$ ia iplv. ialah - 24 ajoen, 156/20,161/31/34 en pass. id., door Tromp weergegeven met „schommel”. Deze bestaat uit een plank, die men wel in huis of voorgalerij ophangt om als zitplaats te dienen, vollediger ajoen papan, als in KV 39. (Vgl. de toejang papan der Ngadjoes, Hdl. sv. tujang). Onder ajoen zonder meer verstaat men gewoonlijk de schommelwieg van doeken, die in het mal. ajoenan heet. Dat Poeteri Djoendjoeng Boejah steeds wordt voorgesteld als te zitten op een schommel, is zeker niet toevallig. Op deze plaats tovert zij aldus gezeten haar rijdier te voorschijn. 's Vorsten dienaar treft haar op de schommel zittend aan $(156 / 20)$, Adji Batara Agoeng Déwa Sakti neemt haar plaats daarop in, als zij zich voor hem verstopt (161/31), het meisje Djaroema verraadt, dat zij niet de ware is, door niet op de schommel te willen dit zal betekenen ,durven” - plaatsnemen (162/26 vv.). Vermoedelijk beduidt dit alles, dat de prinses een dézwa was, een priesteres, die met de hogere machten in verbinding kan treden. Het schommelen is immers een der belangrijke handelingen bij de uitoefening harer functie (vgl. Tromp bl. 89). Voor de betekenis van het schommelen levert de Sal. nog een belangrijke aanvulling op de door Kruyt in zijn artikel „Het schommelen in de Indische Archipel” (Bijdr. 97, 1938, bl. 363-424) meegedeelde gegevens. Zeven keer heen en weer schommelen doet namelijk Maharadja Sakti, Maharadja Soeltan en Maharadja Indramoelia door de lucht vliegen naar Java, op welke luchtreis de hoogste hemelse gewesten worden bereikt (195 v.). In KV 44 verdwijnt de zich door haar man bedrogen achtende Poeteri Karang Melenoe $=\mathrm{P}$. Djoendjoeng Boejah door dezelfde handeling uit deze wereld in het water, weldra door haar man op gelijke wijze gevolgd. In deze mythen doet de schommel duidelijk dienst als middel om aan deze aarde te ontstijgen. - 26 satoe sembawa, 28 id., volgens Tromp 216 is sembawa een geest, vgl. echter litt. jav. sato sembarea, tijgerachtig beest, 
ook tijgermom in optochten (zie ook Pigeaud, Volksvertoningen § 178). Vermoedelijk is de toevoeging van dit woord een latere verfraaiing van de tekst, daar sato sembawa geen verdere rol speelt, of wel is het op te vatten als een andere benaming voor lemboe soeana, in welk geval dan hier en in r. 28 later zou zijn ingevoegd. - $29 \mathrm{~N}$ iplv. itoepoen; dit moet niet iapoen, doch ipoen gelezen worden, hetgeen in het koet. ,ja" betekent als antwoord op de woorden van een meerdere. Het komt ook voor $160 / 5$ en $238 / 32$, vgl. KV 36 en 37. Op grond van deze verbetering moeten de aanhalingstekens na soeana geopend worden; het gebruik van karena is nu ook begrijpelijk. Ipoen beschouwt men te Tenggarong als een afkorting van inggihpoen, dat ook in gebruik is. Het zou echter ook een hoog woord voor ja (ia) kunnen zijn op voorbeeld van jav. ipoen, evenals dit laatste woord in het bal. zelfstandig voorkomt als hoog woord voor het pronominale $i a$. Het element poen in inggihpoen is een in koet. en bdj. veel in de aanspraak tot hogergeplaatsten gebezigde partikel, vgl. 199/30 (ada poen), $202 / 20 / 33$ (terada poen). Het wordt ook evenzo als ipoen gebruikt en als antwoord, wanneer men door een hogere wordt geroepen (=lamp. poen, jav. noen, snd. koelan, kah). $-30 \mathrm{~N}$ boenji iplv. kata.

\section{8}

1 lawang, 223/28 en pass. id., in koet en bdj. het gewone woord voor mal. pintoe (jav.). $-2 \mathrm{~N}$ s.poe ${ }^{2}$ basa $-3 \mathrm{~N}$ diterbangkannjalah 4 tengkas, t.r. tangkas $-5 \mathrm{~N}$ als Tnt. 3 ; de tekst is een weinig in de war. - 7 hampir ( $\mathrm{N}$ ampir) wordt hier enige malen gebruikt om een aan zekerheid grenzende waarschijnlijkheid uit te drukken; hier vertale men: „als de mensen de prinses niet gezien hadden, zouden zij wel allen op de loop zijn gegaan." Vgl. 204/30 perasaan patik hampir laloe poelang roepanja, ,ik ben van gevoelen, dat hij wel naar huis zal zijn gegaan”; ib. 32 hampir benar seperti kata adinda itoe, „hoogstwaarschijnlijk heb je het aan het rechte eind." Zie tenslotte ook 161/12. Of zodanig gebruik van hampir ook elders voorkomt, weet ik niet. In het hedendaagse koet. komt het woord niet voor, ook niet in de gewone zin van bijna, waarvoor men dikit lagi zegt. $-13 \mathrm{~N}$ als Tnt. $6-$ 14 v. $\mathrm{N}$ mindargili $-16 \mathrm{~N}$ als Tnt. $8-20 \mathrm{~N}$ als Tnt. $10 .-21 \mathrm{~N}$ pendaoengan iplv. pondongan $-23 \mathrm{~N}$ rantjas $-25 \mathrm{~N}$ soearanja $26 \mathrm{~N}$ pendaoengan iplv. pondongan (bis) - sampoen, 143/3, 198/35, $236 / 4$ id., hoog woord voor soedah (jav.) $-27 \mathrm{~N}$ bintir iplv. het 
juiste sebintir (vgl. 132/10) - N bilah na tweede gigi, waarvoor met $\mathrm{S}$ sebilah moet gelezen worden. $-29 \mathrm{~N}$ als Tnt. $14-31 \mathrm{~N}$ belari.

\section{9}

$1 \mathrm{~N}$ berdaoeng iplv. berdaboeng. $-6 \mathrm{~N}$ masinglah. $-10 \mathrm{~N}$ petola iplv. patolo. $-13 \mathrm{~N}$ dan na sapi ontbr. - $14 \mathrm{~N}$ peridjas. - 15 melénggang, sc. papan, zie 132/32. - menjaoeng, 29, 144/15 id.; koet. njaong, besaong $=$ mal. menjaboeng, bersaboeng. Hierbij 141/17 penjaoengan, hanekampplaats. Menjaong roempoet betekent volgens Tromp, aant. 218 ,uit eenige strootjes het kortste trekken", wat het begrip menjaong geen recht doet wedervaren. Mij werden twee methoden van dit spel meegedeeld: 1e. de spelers haken twee geknakte sprietjes van het belolang-gras (Eleusine indica) in elkaar en trekken: hij wiens sprietje doorbreekt verliest; 2 e. twee losse bloemsteeltjes van het oeloe-oeloe tjina genaamde kruid (een laag gewas met vierkante stengel, waarvan de afwisselend bloeiende kleine, witte bloempjes (Papilionaceeën) in ronde hoofdjes bijeen staan), worden door de spelers met een slag achter de bloeiwijzen ineengedraaid, waarna $z \mathrm{ij}$ trekken : hij wiens bloeiwijze geheel of gedeeltelijk van het steeltje loslaat, verliest. $-18 \mathrm{~N}$ menjan ontbr., vandaar het verschil tussen $\mathrm{B}$ en T. $-26 \mathrm{vv}$. Tromp heeft van de hier volgende merkwaardige passage een uitleg trachten te geven, die in het kort op het volgende neerkomt: Uit vrees, dat de boze geesten in hun afgunst op het geluk der Oeloe Doesoenners hun kwaad zouden berokkenen, schiepen zij „,een omgekeerde wereld, een rare boel", om die geesten te misleiden. Deze animistische verklaring, waarbij enige inlegkunde te pas moest komen, kon Van Ossenbruggen, die in zijn beroemde verhandeling over „Het primitieve denken", $\S 209$, de passage aan een nader onderzoek onderwierp, niet bevredigen. Terecht kwam hij tot de conclusie, dat degenen, die de „dolligheid”, de „rare handelingen” uithaalden, niet de lieden van Oeloe Doesoen zelf waren, doch de bezoekers van elders. $Z$ ij deden dit bij wijze van ,tegen-magie”, uit vrees voor ,de gevolgen eener zonder twijfel sterke, immers op zulk eene buitengewone wijze zich uitende magie". Bij deze verklaring schijnt Mees (bl.62 v.) zich aan te sluiten, den auteur zonder hem in dit verband te noemen, bijna letterlijk aanhalend met de woorden: ,de gevolgen van een zo sterke, zich op zo buitengewone wijze uitende magie".

Wat de bedoeling aangaat, dunkt mij Van Ossenbruggen's verklaring in hoofdzaak bevredigend, doch de moeilijkheden, die de letterlijke ver- 
taling van enkele regels oplevert, heeft hij niet uit de weg geruimd. De eerste moeilijkheid is gelegen in de woorden der bezoekers (r. $26 \mathrm{v}$.), waarvan het begin letterlijk weergegeven aldus luidt: „laten wij dit haar (hun) land (kampong) omkeren, opdat wij niet door haar (hen) overheerst worden", waarbij het van ondergeschikt belang is, of -nja doelt op de bewoners van Oeloe Doesoen (Mees, bl. 72 „hun”, „zij”), dan wel, wat mij waarschijnlijker voorkomt, de prinses zelve. Van Ossenbruggen's vertaling luidt : „Het zou goed zijn, als wij den boel hier in dit landschap .... onderste boven keerden, opdat niet [het te machtig worde, n.l. door de t.o.v. de prinses zich gemanifesteerd hebbende magie, en] wij erdoor worden onderworpen." Hierin wordt het eerste -nja verdonkeremaand, terwijl het tweede wordt beschouwd als op benoea terug te slaan, wat niet zeer aannemelijk is. De eigenlijke moeilijkheid is echter gelegen in het tweede gedeelte der uitspraak: baiknja hidoep tiada djoea kita empoenja kebesarannja. Van Ossenbruggen vertaalt dit met ,al zouden wij er het leven bij houden, zoo zouden wij toch onze onafhankelijkheid - kaběsarannja - verliezen", ongeveer evenals Tromp, die kebesaran echter met "grootheid" weergeeft. Deze vertaling is natuurlijk wegens het aan kebesaran gehechte pron. poss. 3e pers. niet te handhaven. Mees, wiens uitgave kita empoenja kebesaran leest, vertaalt in de inhoudsopgave (bl. 72) niettemin naar Tromp's tekst ,al zouden we blijven leven, wij zouden hun grootheid niet hebben", hetgeen men wel als letterlijke weergave zou kunnen verdedigen, doch waartegen pleit, dat ,het hebben van eens anders grootheid" een wel zeer weinig Indonesische gedachtengang zou verraden. Ook mist men bij deze opvatting node het pron. rel. jang na kita.

Hs. N, en hiervan zullen wij zoals gewoonlijk verder uitgaan, leest echter kita empoen kebesarannja. Empoen zou men gelijk kunnen stellen aan bdj. ampoen, wat syn. van mal. empoenja is, als in nang ampoen tjarita $=$ mal. jang empoenja tjerita, e.d. Op de vertaling zou deze lezing geen invloed uitoefenen, terwijl men er dezelfde bezwaren als boven geopperd tegen zou kunnen aanvoeren. امفوز laat echter ook de lezing ampoean toe, en dit betekent in het jav. ,een verlamde toestand waarin iemand door een machtige werking van iemand of iets gebracht wordt, .... geraaktheid of beroerte, waarmee iemand tot straf door een bovennatuurlijke macht geslagen wordt" (GR). Is dit woord hier bedoeld, dan zou ampoean kebesarannja betekenen ,geraakt, aangetast door de invloed van haar grote bovennatuurlijke macht", haar „magie”. Bij deze gissing, die ik slechts zeer aarzelend opper, daar 
mijn schriftelijk naar het voorkomen van dit woord te Tenggarong gedane navraag geen succes heeft gehad, moet natuurlijk ook de vertaling van de voorafgaande woorden baiknja hidoep gewijzigd worden. Alle vertalers hebben stilzwijgend aangenomen, dat het subject van hidoep het elders in de zin yoorkomende kita is. Baiknja moet dan „ook al, of schoon" betekenen, en inderdaad schijnt het zo voor te komen, naar valt op te maken uit de wedergave van het woord "ofschoon" met baiknja anoe in een door den vroegeren controleur van Tenggarong, L. A. Emanuel, ingevulde, thans bij het Bataviaasch Genootschap berustende koet. woordenlijst. Anoe schijnt daar ter vervanging van het subject in een zin te figureren. Nu komt echter in de Sal. 145/21 baik, en niet baiknja, in dezelfde bet. voor: baik kita tahoe, enz., „ook al wisten wij het ...." Daarom ben ik geneigd aan te nemen, dat ook hier baik als voegwoord fungeert, terwijl -nja de functie heeft van een pron. pers. 3e pers., enclitisch aan het voorafgaande woord gevoegd (vg1. aant. bij 125/10). De betekenis van dit zinsdeel is dan: „ook al leeft zij (leven zij)", welke vertaling overigens eveneens kan gelden, als baiknja als een ondeelbaar voegwoord moet opgevat worden. De gehele zin kan nu, met aanname van bovenstaande, enigszins gewaagde gissing, en met het voorbehoud, dat de passage zeer wel corrupt kan zijn; als volgt worden vertaald: ,ook al blijft zij in leven, toch zullen wij niet aangetast worden (onder de invloed komen) van haar grote bovennatuurlijke macht".

Een andere moeilijkheid schuilt voor den vertaler in de woorden djangankan balik (me)bara-bara mangkin bertambah-tambah terang tjoeatjanja (140/4). Waarschijnlijk door het onbekende derde woord in de war gebracht, hebben zowel Tromp als Van Ossenbruggen - naar hun vertalingen kan worden verwezen - het zinsverband uit het oog verloren. De bedoeling, wat het (me)bara-bara ook moge betekenen, is : "maar laat staan, dat er een natuurramp plaats had, het werd juist hoe langer hoe fraaier weder." En dit was natuurlijk nog een bewijs te meer voor de wondermacht der prinses, die zelfs de sterke "tegenmagie" der bezoekers te niet wist te doen! - $27 \mathrm{~N}$ امفوز , empoen of ampoean? iplv. empoenja, zie vorige aant. - $28 \mathrm{~N}$ kebesarannja. $29 \mathrm{~N}$ iplv. dadi, lees dadéh, koet. rijstschep (Tromp's spelling dadi is fout). - kedoet, lees kadoet. - 30 tengkelasa, aldus, en niet tengkelasas, zoals ik in Bespr. 302 op gezag van vdW opgaf, is de gewone koet. uitspraak van het woord, cameleonachtige hagedis, rgl. 
Min. tangkalaso en Wilk. sv. tengkelasak. - toempang, koet. kikvors of padde (mak. id. padde). $-31 \mathrm{~N}$ berkatjapikan. $-32 \mathrm{~N}$ als Tnt. 13. - 33 goeloeng is blijkbaar een schrijffout, die door TK juist in gendang is verbeterd. - tirisan, koet. zeef.

\section{0}

1 boeah gajam, Tromp aant. 222 leest t.o. b. gajang (de mol.-mal. vorm!), en verklaart ,een doosje voor sirihpruimen, gewoonlijk gemaakt in den vorm van de gajang-vrucht." Volgens mijn inlichtingen is het echter een doosje bestemd voor lenga bébér, koet. lipzalf, gebezigd bij het sirihpruimen. - étér, Tromp aant. 223 ,rijstmaatje van klapperdop". Gewoonlijk gebruikt men étér alleen na telwoorden om een bepaalde hoeveelheid aan te duiden, terwijl het voorwerp zelf étéran wordt genoemd (koet.). -2 keliawat, Tromp aant. 224 ,langarmige aapsoort", koet. Hylobates concolor, vgl. ng. kalawet, br. kalabat enz. 3 takoet akan balik, hier moet vermoedelijk hari bij gedacht worden, vgl. 121/30. - bara-bara, in $\mathrm{N}$ onduidelijk $b . r a^{2}$ gespeld, eventueel $m . b . r a^{2}$ te lezen. Noch Mees' verklaring, die het als syn. van sara-bara beschouwt, noch een te Tenggarong geopperde gelijkstelling met garagara is bevredigend. De best passende bet. schijnt mij „veeleer”, mal. malahan (vgl. jav. en snd. bara-bara, gelukkig dat?). Zie verder aant. 139/26 vv. - 5 setikas, volgens Tromp aant. 227 ,allen", precieser $:=$ mal. sehingga, voorzover behorend tot (koet.). Tikas komt in bdj. en ng. zelfstandig voor, en betekent daar grens, totaan. $8 \mathrm{~N}$ als Tnt. 3. $-9 \mathrm{~N}$ diakoe iplv. tweede diakoenja. - 10 sanggan, t.r. senggan, koet. metalen kom, gebruikt om er een drinkglas of een tembokang in te plaatsen. Volgens Snouck Hurgronje leest B hier sasanggan, wat bdj. is voor ronde koperen kom. - tembokang, Tromp vertaalt „waschkommetjes" (bij vergissing werd in Bespr. 310 opgegeven, dat hij sanggan $t$. weergaf met „koperen waschkommetjes”); men verstaat te Tenggarong onder tembokang diepe, vaasvormige vingerkommen van gedreven metaal, wel te onderscheiden van $k o b o^{s} a n$, die het gewone vingerkommodel hebben. Klinkert heeft tembokan als syn. van kémbok. - $11 \mathrm{~N}$ masing2lah. - $12 \mathrm{~N}$ berdjandjian iplv. berdjandji. 13 - 15 De afspraak is niet duidelijk en vermoedelijk corrupt. - $14 \mathrm{~N}$ als Tnt. 7 en daarna dan. - djangan kita ingat-mengingatkan schijnt te betekenen "laten wij elkander niet (behoeven) te waarschuwen". Tromp parafraseert ,men zou niet wachten, tot men daaraan herinnerd werd." - 15 koetjah-mengoetjahkan is onbekend; mijn helpers stelden zonder aarzeling voor poetjah-memoetjahkan te lezen, koet. elkaar zijn 
gang laten gaan, elkaar laten begaan, zich niets van elkaar aantrekken. Vgl. kenapa poetjahkan adis awas toeroen ketanah? waarom heb je je broertje naar buiten laten gaan? (voor poetjahkan, blijkbaar afgekort van di- of awas poetjahkan zou ook het syn. liatkan kunnen staan.)' Deze lezing was vermoedelijk ook de bedoeling van Tromp's zegsman; Tromp spelt poetja-memoetjakan, en vertaalt in aant. 229 ,onverschillig zijn, doen alsof men het te druk heeft." - $16 \mathrm{~N}$ als Tnt. 10. $19 \mathrm{~N}$ berdiam. - 24 roemadja, elders id. Ook de gewone uitspr. in 't bdj. - $25 \mathrm{~N}$ terseboetlah. - $27 \mathrm{~N}$ Agoeng na Batara. -

$30 \mathrm{~N}$ spelt hier en 141/21 duidelijk iplv. saja, beide keren in de mond van den Chinesen radja. Is dit slechts een vergissing of duidt het op een kromme uitspraak?

\section{1}

$5 \mathrm{~N}$ dipolah iplv. diperoléh, 7, 9, 225/29, 232/11 id.; molah (dipolah), koet. maken; zie nog 258/7 memolah negeri $=$ mal. berboeat negeri. Hierbij ook 226/33 dipolahkan. Manok dipolah is dus een kunsthaan, welke, blijkens $142 / 2$ bewogen werd door een veerwerk. $-7 \mathrm{~N}$ dipolah iplv. diperoléh. $-8 \mathrm{~N}$ mano's iplv. manoekkoe. $-9 \mathrm{~N}$ abusievelijk tembagalah. - $\mathrm{N}$ dipolahnja iplv. diperoléhnja. De uitdrukking besikah tembagakah dipolahnja geeft een gebruik van kah te zien, dat in de koet. en bdj. spreektaal zeer gewoon is. Vgl. in de Sal. 234/20 iakah ikan iakah mendjangan, hetzij het (of het nu al) vissen waren of herten; 265/9 biasamoekah lain pada biasamoekah beratkah ringankah, of gij het al gewoon zijt of niet, of het zwaar is dan wel licht; 146/21 sepoeloeh boengkalkah, doea poeloeh boengkalkah, (zooals $\mathfrak{u}$ maar wenst) tien boengkal of twintig. Soms staat in plaats van een dezer kah's atau (atawa), of wordt dit laatste ten overvloede toegevoegd: $253 / 15 \mathrm{v}$. tiada ia maoe berkotakan tanah atawa kajoekah, zij wilden geen verschansing van aarde noch van hout maken; $145 / 19$ atawa djalan perahoekah atawa djalan daratkah, hetzij per boot, hetzij te voet; $238 / 21$ djikalau akoe mati ésokkah atau loesakah, als ik kom te sterven, morgen of overmorgen. Zie nog 163/14 atau boeboekkah, 167/33 atau matikah, 168/3 bekerdjakah atan ...., 208/30 baikkah djahatkah atau kerongokah, 220/11 iakah .... atau. Dit gebruik van kah komt overeen met dat in het mal. van Ambon, bv. dia pigikah tradakah, béta tra mistér, „of hij gaat of niet, 't is mij om 't even. Vgl. ook inikah itoe, ,dit of dat?" (Van Hoëvell, Vocabularium bl. 50). $-12 \mathrm{~N}$ als Tnt. $2-17 \mathrm{~N}$ penjaongan iplv. penjawoengan - bersebelahan tempat, naast elkaar, naar 
mij voorkomt een weinig gebruikelijke vorm. $-20 \mathrm{~N}$ apa akan iplv. apakan - taroeh, 145/1, 146/19/23, ,inzet”, een gewone bet., die men wel in Aanh. vdW maar niet bij Klinkert of Wilkinson vindt, evenmin als taroehan in dezelfde zin. Vgl. Toehfat an-Nafis, ed. Winstedt, bl. 31 ben., taroeh en taroehan als syn. gebruikt in twee opeenvolgende regels. $-21 \mathrm{~N}$ itoe ontbr. (vgl. Tnt. 4) -25 perahoe radja Tjina itoe dengan dan wel $d . p$. wangkang $r . T j$. $i$. is te veel. -26 menanjaï, volledigheidshalve worde de aandacht gevestigd op deze actieve vorm, die volgens Klinkert alleen in geschriften van Europeanen of vertalingen wordt aangetroffen. -28 andika, $144 / 18$ v., 155/6 v. en pass., koet. pron. pers. 2e pers. tot zeer hoog geplaatsten, corresponderend met patik voor de le persoon. In 't bdj. correspondeert het thans nog slechts in enkele streken en met plaatselijk sterk verschillende waarde gebruikelijke pron. met kaoela of kola. $-30 \mathrm{~N}$ als Tnt. $5-32 \mathrm{~N}$ als Tnt. $6-$ Djoeng Pérak Kemoedi Besi, 162/8 id. (Edjoeng); dit is waarschijnlijk niet maar zo een of andere fantastische naam, doch een technische benaming voor een haan van bepaalde pluimage. Kemoedi besi betekent evenals het bdj. kamoedi wasi (vgl. Cense, Kroniek van Bandjarmasin bl. 83, ajam poetih kemoedi wasi) een haan van één kleur (gewoonlijk wit) met één enkele zwarte veer in de staart. Het gebruik van het woord kemoedi wijst er reeds op, dat men vechthanen met schepen vergelijkt, zoals hier ook in djoeng pérak tot uiting komt. Dit laatste kan moeilijk iets anders betekenen, dan dat de haan geheel wit was. Goud, zilver en ijzer staan in poëtische beschrijvingen zoals men weet voor de kleuren dezer metalen, zodat de zilveren pootschubben en de ijzeren sporen in de volgende woorden, en de ijzeren nagels van $162 / 8$ prozaïsch gezegd witte schubben en zwarte sporen en nagels zijn. Of bokor tembaga (141/33) en doelang emas (146/18) eigenlijk evenzeer technische benamingen zijn, ben ik niet te weten kunnen komen. Natuurlijk houden deze namen wel een toespeling op de pluimage der hanen in. $-33 \mathrm{~N}$ als Tnt. $7-35 \mathrm{~N}$ disalah iplv. disalahkannja; vermoedelijk moet salah worden gelezen. Disalahkannja wordt echter $148 / 20$ ook in N gevonden.

\section{2}

$1 \mathrm{~N}$ als Tnt. $1-2 \mathrm{~N}$ als Tnt. 3, echter djoea iplv. djoega $-4 \mathrm{~N}$ als Tnt. $4-\mathrm{N}$ loet iplv. loeka -5 Haridjaja, 8 id.; dit is blijkbaar de timang-timangan van den haan. Wat de aanleiding tot de benaming kan zijn ontgaat mij. $-7 \mathrm{~N}$ digérék ${ }^{2} k a n n j a$ iplv. digiringkannja; 146/34, 148/25 id., 147/25 digérékkannja, 150/1 menggérék-gérékkan. - patoek, 146/34 en pass. id., koet. patos, snavel, bdj. jav. patoek 
id. $-8 \mathrm{~N}$ laloelah $-15 \mathrm{~N}$ radja ontbr. $-\mathrm{N}$ dipintaslah $-16 \mathrm{~N}$ als Tnt. 8-17 $\mathrm{N}$ dengan serta ontbr. $-\mathrm{N}$ als Tnt. $10-18$ bertanggoeh, uitstel bedingen, vgl. 243/2 ditanggoehi, uitstel erlangen. Klinkert geeft bertanggoeh weer met ,uitstellen", Wilkinson met ,to grant an extension of time; to adjourn", doch vgl. Hik. Sri Rama Maxw. 68, r. 1 v.o. akoe bertanggoeh kepada engkau didalam toedjoch hari ini, ,ik vraag u uitstel tot over zeven dagen". - $19 \mathrm{~N}$ als Tnt. 11, doch aan het begin nog dan. - $20 \mathrm{~N}$ itoe iplv. itoepoen - berdjinaka, N abus. bertjinaka; huidig koet. bedjenakas, liegen $=$ mal. berdoesta; ndjenakas $i$, bedriegen $=$ mal. mendoestaï. Vgl. 186/3 en Bespr. 302, noot. $-\mathrm{N}$ bepadah ia semoeatnja iplv. ia berpadah semoeanja. Hier moet iets uitgevallen zijn. Bepadah ia geeft geen zin (misschien moet hiervoor bepedaja gelezen worden, vgl. aant. 162/15), en men mist de vermelding van de personen, die de opdracht kregen hout te verzamelen. Uit het volgende is op te maken, dat dit de helft der schepelingen waren. $22 \mathrm{~N}$ separo iplv. separoeh $-24 \mathrm{~N}$ lajar na mendjahit $-26 \mathrm{~N}$ baloe iplv. beloem, men leze $b a(h a) r o e(l a h) .-\mathrm{N}$ als Tnt. $13-29 \mathrm{~N}$ maksoed $-31 \mathrm{~N}$ eerste itoe ontbr.

\section{3}

1 tegoer, 152/28, 179/29 en pass. id., koet. in opschudding, „riboet”, $=$ gégér, gewoonlijk ten gevolge van een alarmsein; vgl. evenzo sd. tegoeran, ,the disturbance in a Dyak community which usually follows upon an alarm." Vgl. 179/28 maka orang diloearpoen tegoer mengatakan ada orang berhanjoet dari Menamang met 194/10 v. maka orang diloear kotapoen gégérlah mengatakan orang berhanjoet dari hoeloe. Hierbij ook 179/31 tegoerkan. Als mal.: 156/16, 181/21 ditegoer. $3 \mathrm{~N}$ als Tnt. 1 - 4 menoentoeti, 158/32/34, 169/24 id. ; 143/6 v., 173/10 ditoentoeti, $145 / 18 \mathrm{v}$. kita toentocti; in de zin van achternagaan, mal. menjoesoel, steeds met suff. $-i$ als in het bdj. $-5 \mathrm{~N}$ als Tnt. 2, semoempoeng, koet. zolang als, terwijl nog (van de gelegenheid gebruik gemaakt kan worden), i.q. jav. moempoeng. - parak, koet. en bdj. = mal. dekat, jav. parek. In parak siang, 155/5, dat door Koetaiers en Bandjarezen wordt opgevat als „dichtbij” het aanbreken van de dag te betekenen, is parak vermoedelijk van andere oorsprong. De uitdrukking komt immers ook voor in het min. (,antara malam dengan siang”, Kamoes), in welke taal paras in de zin van nabij overigens niet bekend is. Wilkinson geeft perak siang, blijkbaar een gemalaiseerde vorm. Vermoedelijk is het arab. farak, het allereerste morgengloren. $-6 \mathrm{~N}$ als Tnt. $3-$ 9 rapak, koet. gronden, die jaarlijks gedurende lange tijd onder water 
staan of drassig zijn (definitie naar Endert Exp. bl.213). In de landbouwkundige litteratuur wordt het woord tegenwoordig ook gebruikt voor dergelijke gronden in de Zuiderafdeling van Borneo. Het is echter noch Bandjarees, noch Ngadjoe. $-10 \mathrm{~N}$ als Tnt. $6-\mathrm{N}$ tiadalah $12 \mathrm{~N}$ als Tnt. $7-\mathrm{N}$ wangkangnja iplv. wangkang itoe $-14 \mathrm{~N}$ persepatan iplv. persipatan, $18 \mathrm{vv}$. id.; koet. persepatan of gewoonlijk sepatan, grens. - 15 Basap en (16) Daja, namen van twee Dajakstammen, zie Tromp aant. 24. - $17 \mathrm{~N}$ als Tnt. 10 - désa betekent hier racjat, onderhorigen, onderdanen. Hoewel $174 / 20$ van negeri's wordt gezegd, dat zij iemands désa zijn, wordt er toch meer aan de inwoners gedacht dan aan het onderhorige land. Gewoonlijk ontmoet men de combinatie désa racjat, als 209/30 voor onderdanen, onderhorigen. Vgl. Oend. B. N. fasal 15, bl. 307/3 djika menteri memboenoeh désa racjatnja, wanneer een menteri een zijner onderhorigen heeft gedood (niet als Mees vertaalt „een van zijn desalieden”). Zie ook KV 65. Ook in de bdj. litteratuur komt men de samenstelling vaak tegen, bv. in de Hik. Bandjar (hs.) sekalian désa racjatnja itoepoen semoeanja menjembah. Sommige Bandjarezen, die zich gaarne litterair uitdrukken, hoort men wel het woord désa gebruiken in de zin van „man uit het volk”. Als geografisch

begrip is het woord in deze streken niet bekend. - $19 \mathrm{~N}$ iplv.

Teboek, 178/21 id.; de uitspraak schijnt $T a b o^{5}$ te zijn; men noemde mij Batoe Tabos als de naam van een berg in het boven-Menoebarse, waar de grens ongeveer moet lopen. Tromp spelt op bl. 8 Těbah, maar dat kan hier nooit gelezen worden, wel eventueel $T a b a^{s}$ of $T e b a^{s}$. 20 sampar, koet. tot aan, = mal. hingga. - Koran, de juiste uitspraak is Koeran, een andere naam voor Berau. Vgl. H. von Dewall, Aanteekeningen omtrent de Noordoostkust van Borneo (TBG 1855), bl.433 : „De namen zoowel van Koeran als van Berou, zijn ontleend aan die van kleine spruitjes der groote rivier. De boegineezen en andere om de zuid wonende volken ter oostkust van Borneo, bedienen zich van de uitdrukking "Berou" voor land en volk; de noordelijk wonende landzaten zeggen „Koeran”." $-26 \mathrm{~N}$ laloelah $-27 \mathrm{~N}$ abus. dis.pitnja iplv. disoempitnja. $-31 \mathrm{~N}$ als Tnt. 13.

\section{4}

$4 \mathrm{~N}$ مسؤرة iplv. moesjawarat, een spelling die op de uitspraak mesaoerat wijst; 164/21, 193/10 v. id., mesaoeratkan 193/8, zie aldaar. -7 pedalaman, $166 / 10$ en pass. id. = dalam (jav. dalem). Volgens 
Tromp bl. 19 zou men in Koetai kadalaman gebruiken naast dalam, wat vermoedelijk een vergissing is voor het onderhavige woord. - 13 $\mathrm{N}$ wajahnja iplv. wadjahnja; wajah, koet. en bdj. tijd, = mal. waktoe (jav.). $-15 \mathrm{~N}$ als Tnt. $3-16 \mathrm{~N}$ orang iplv. orangnja (vooraf gaat membawas, dat echter is doorgehaald; vgl. Tnt. 4) - N tetapi - 19 kealatan, $145 / 23$ id. is blijkbaar = alat keradjaan. $-22 \mathrm{~N}$ als Tnt. 8 - teroes peningal, jav. teroes ing paningal, helderziend. 191/24 en $197 / 15$ wordt aangetroffen een verbastering van deze uitdrukking: teroes tan peningal (of tanpa ningal), naast het evenzo verbasterde sidik tanpa ngoetjap ( $\mathrm{N}$ tan pengoetjap). Misschien vatte de schrijver het op als „doorvorsend zonder zelfs ook maar te kijken"? Tan zou een fout voor jav. tang kunnen zijn. - dikoe, lees diakoe met $\mathrm{N}$, die weinig elegant, maar overduidelijk دي ياكو spelt; hierna aanhalingstekens sluiten. $-23 \mathrm{~N}$ als Tnt. $9-25$ sotja loedéra, jav. sotja loedira, robijn of een bepaald soort van gouden ring. In de bdj. litteratuur is dit, gewoonlijk soetjaloe dira uitgesproken, de naam van een van de goden afkomstige wonderring. - 26 djingga pengaras, in Koetai nog gebruikte benaming voor donker oranje. Het woord komt veel in de bdj. litteratuur voor. Wilkinson geeft het woord, dat hij aantrof in de Hik. Mas Edan (hs. Cambridge) weer met "sunset-yellow”. - 27 bergeloeng kelingan manggar (N مثخر ), vgl. 160/16 b. k. امغكور اؤكل 226/6 b. k. m.ngkoer ikal. Wat is de juiste lezing en de betekenis? - merak mengigal als model van een soemping; vgl. Klinkert ,in dien vorm heeft men gouden knoopjes" en zie ook aant. bij 136/27. - 28 bergaroeng, $\mathrm{N}$ بركزوأ, te lezen bergerawang; koet. gerawang = mal. kerawang. De beroemde Boerit Kang is inderdaad een opengewerkte kris, zoals ook op de afbeelding bij Tromp (Plaat V) duidelijk is te zien. - 29 Kelamoe jang, lees kala-moejang; vgl. jav. kala moenjeng, naam van een rechte kris bij J. en $\mathrm{P} . \mathrm{V}, 210$, no. 38 , en ,kalam moenjeng" bij GR sv. oenjeng, naam van een kris. Jav. moejeng=moenjeng.

— N als Tnt. 12 halambak ( حلمبق ), 251/6 id. ( حلمبو ). Wilkinson geeft deze uitspraak naast kelembak. Als ingrediënt van een oerap-oerap vinden wij deze stof ook in de Malat (KBW sv. kalembak). $-31 \mathrm{~N}$ als Tnt. $13-32 \mathrm{~N}$ jang ontbr. $-\mathrm{N}$ als Tnt. 16. 
$1 \mathrm{~N}$ jang ontbr. - $\mathrm{N}$ als Tnt. $1-3 \mathrm{~N}$ panakazeannja $-4 \mathrm{~N}$ maka na tweede itoe $-7 \mathrm{v}$. boedjak, 154/29 id., koet. speer, br. ser. sd. id. $8 \mathrm{~N}$ maka disocrochnjalah iplv. disoeroehnja $-9 \mathrm{~N}$ dibatisnja iplv: dibetis; betis, $154 / 21$ en pass. id., koet. voet met onderbeen $=$ mal. kaki, bdj. batis. - $11 \mathrm{~N}$ asoekoe iplv. sikoe (vgl. Tnt. 3). N heeft ook elders, bv. 195/33 en pass. asoekoe toenggal, en éénmaal (160/26) soekoe toenggal. Sedakap (a)soekoe toenggal is jav. sedakep $s$. $t$. de handen over de borst gekruist en met aaneengesloten benen (volgens sommigen „op één been staan"). KBW geeft ook de vorm masoekoe t., wat grammaticaal gelijkwaardig is aan asoekoe $t$. Mal. teksten hebben gewoonlijk bersoekoe toenggal (vgl. Cense, De Kroniek van Bandjarmasin, Stelling VII) naast de verbastering bersikoe $t$. Vgl. Klinkert sv. sikoe, Aanv. Mal. Wdbn. bl. 3 en KBW sv. soekoe I en babah. $-13 \mathrm{~N}$ itoepoen iplv. eerste itoe. - N gaib - 15 koeasa heeft in de Sal. steeds de bet. "tovermachtig", vgl. 188/14, waar het syn. van sakti (188/3) is en 191/24. In overeenstemming hiermee betekent pengoeasaan $241 / 25$ v., 28,30 en pass. magisch vermogen, toverkunst. - 17 pemergiannja, $20 \mathrm{id}$. Wij moeten vertalen ,(de plaats) waar hij is heengegaan”, doch grammaticaal gesproken is pemergian een substantivering van pergi (de handeling); vgl. 204/23 tiada kakanda ketahoeï akan perginja, wat betekent: ik weet niet, wáár hij is heengegaan, en niet: dàt hij is weggegaan. 153/23 akoe datang dari pemergian is de bet. "letterlijk". - 19 atau, $\mathrm{N}$ leest hier en pass. atazea, wat in koet. en bdj. gewone spreektaal is. $-22 \mathrm{~N}$ dan ontbr. - $29 \mathrm{~N}$ spelt steeds temenggoeng iplv. toemenggoeng naar koet. uitspraak. $-33 \mathrm{~N}$ als Tnt. 10, t.r. dipatoean - $\mathrm{N}$ dipatoean iplv. tweede dipcrtoean, wordt ook verder steeds zo gespeld. Men merke op, dat, behalve eenmaal in deze regel en 159/30: steeds dipatoean wordt geschreven iplv. jang dipatoean, zoals de titel moet luiden, ook in Beroenai. Vgl. o.a. Spenser St. John, Life in the forests of the far East, II (1862), bl.245: „The government consists of a Sultan, now [? K.] dignified by the higher title of Iang de per Tuan". - $34 \mathrm{~N}$ itoe iplv. maka, maar met een andere hand ingevuld waar door vochtwerking het oorspronkelijke woord geheel is uitgewist.

\section{6}

8 itoelah maka adinda datang ini behoort niet tot de woorden van den Sultan van Beroenai, zoals de plaatsing der aanhalingstekens suggereert, doch wordt door den Adji gezegd. Blijkbaar is na bersaboeng 
iets uitgevallen. - $24 \mathrm{~N}$ abus. مغير iplv. mengiring - $\mathrm{N}$ als Tnt. 3; (mem)boelang zou volgens Klinkert alleen min. zijn, het is echter alg. mal., vgl. Wilk. $-25 \mathrm{~N}$ als Tnt. $4-26 \mathrm{v}$. wala-wala, koet. hanekampplaats (boeg.) $=$ mal. gelanggang, wat in r. $28,147 / 16$ vv. gebruikt wordt. Voor de koet. bet. van dit laatste woord zie Tromp aant. 86, bl. 88. - $30 \mathrm{~N}$ dibéntéhnja - 31 merakap, 147/22 id., lees merekap (vgl. transcriptie in I : „merkap"), koet. ineengedoken zitten, zoals een broedende kip, zich tegen de grond drukken. Iplv. merakapnja zal men dus merekap ia als $147 / 22$ of merekap enja moeten lezen. - $33 \mathrm{~N}$ itoe na $A d j i-\mathrm{N}$ Edjoeng iplv. Oedjoeng.

\section{7}

$1 \mathrm{~N}$ als Bnt. 1 ; het is een schrijffout, die met een zeer flauw streepje is doorgehaald. $-2 \mathrm{~N}$ dioras nja iplv. dioerainja $-10 \mathrm{~N}$ als Tnt. 3 -

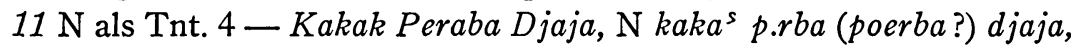
vgl. de naam Haridjaja voor Adji's haan. - $14 \mathrm{~N}$ pangéran staat wel in $\mathrm{N}$, doch is daar doorgehaald (vgl. Tnt. 6). $-20 \mathrm{~N}$ dibéntéhnjalah 22 merakap, t.r. merekap - $24 \mathrm{~N}$ Edjoeng iplv. Oedjoeng - $26 \mathrm{~N}$ bagentar iplv. bergentarlah $-29 \mathrm{~N}$ laloelah $-32 \mathrm{~N}$ als Tnt. $13-$ $33 \mathrm{~N}$ kakanda ${ }^{2}$ iplv. kakanda; men leze dus inilah kemenangan kakanda, kakanda terimalah.

\section{8}

$5 \mathrm{~N}$ itoelah iplv. inilah (vgl. Tnt. 3) $-10 \mathrm{~N}$ als Tnt. $5-11 \mathrm{~N}$ itoe na adji $-17 \mathrm{~N}$ laloelah iplv. tweede laloe $-19 \mathrm{~N}$ maka laloelah iplv. laloe - dititirnja, 21, 149/30, 256/8 id.; titir heeft, althans in koet. en bdj., behalve de gewone bet. ook die van mal. toebi-toebi: menitir, bij herhaling iets doen (gewoonlijk van slaan of steken met een wapen); titir lagi, doe het nog eens, steek nog eens. Vgl. Sj. Ganda Kasoema: pélor datang manitir-nitir, tiada berhanti oeloe dan ilir; Hik. Rahwana: Watoe Goenoeng dipedangnja menitir-nitir. Vgl. litt. jav. nitir. -20 sekali-kali, lees sekali-sekali, telkens weer, keer op keer. $-23 \mathrm{~N}$ itoe na $A d j i-\mathrm{N}$ loet iplv. loeat $-24 \mathrm{~N}$ als Tnt. $10-26 \mathrm{~N}$ bergentar 27 petimban, koet. dodelijke plek, meest kwetsbare plaats. $-29 \mathrm{~N}$ kalahlah - 31 ratoes, lees meratoes of beratoes-ratoes?

\section{9}

$1 \mathrm{~N}$ manosnja $-6 \mathrm{~N}$ diberikannjalah -10 menambiran, drukfout 
of schrijffout voor menembérau $(\mathrm{N})$; koet. nembérau, zijn tegenstander ineens verslaan zonder zelf enig letsel op te lopen. - $14 \mathrm{~N}$ Garang iplv. Gerang - $16 \mathrm{~N}$ taroeh - 20 loempat, 22 id., koet. meedoen, meegaan, meevaren $=$ mal. menoempang (vgl. vdW sv. lompat), bdj. id., doch vaker oempat. Of de technische bet. „mee inzetten op (di) of bij ( $d i$ of kepada)", die loempat hier blijkt te hebben, huidig koet. spraakgebruik is, heb ik niet kunnen vaststellen. In ieder geval is het geen bdj. Vgl. echter boes. noempang, dat zowel als passagier meevaren betekent als meedoen aan de weddenschappen bij een hanengevecht. Voor de semasiologische verhouding tussen mal. en koet. bdj. loempat vergelijke men ng. (tang)kero, dat zowel springen als meeváren betekent. - $29 \mathrm{~N}$ itoe na Adji - 33 berdjadjak, t.r. berdjedjak - $35 \mathrm{~N}$ itoe na eerste $A d j i$.

\section{0}

$1 \mathrm{~N}$ patos iplv. patoeknja $-5 \mathrm{~N}$ itoe na Temenggoeng $-6 \mathrm{~N} \mathrm{keba-}$ lai pengadapan iplv. kembali kepenghadapan - $12 \mathrm{~N}$ doedoeslah 13 langgoei, wel te lezen langgoeai of lenggoeai; in hs. I is de transcriptie Loenggoeai aangetekend. In de br. woordenlijst van Marshall vindt men de opgave lengoeai, ,a large circular brass box with tray for holding sireh leaf and betel nut". Hierbij tekent Moulton aan, dat men in Serawak ook "lunggwai" (is dit loenggoeai of lenggoeai?) hoort. Vermoedelijk is de br. uitspraak langgoeai. Vgl. nog tag. langgrvay en sd. lengoeai naast ringgoeai. Het woord, dat in Koetai niet bekend is, is in de Sal. ongetwijfeld voor de couleur locale gebezigd; uit het zinsverband mag men opmaken, dat de schrijver meende, dat het een syn. van peloedahan was. $-16 \mathrm{~N}$ als Tnt. 3, t.r. disorongkannja $-17 \mathrm{~N}$ dajang $-24 \mathrm{~N}$ als Tnt. $6-34 \mathrm{~N}$ als Tnt. 9.

\section{1}

$2 \mathrm{~N}$ dipatoeanpoen $-4 \mathrm{~N}$ abus. ma iplv. maka - 9 doea makan sirih, een schrijffout voor doea pemakan s.? $-\mathrm{N}$ als Tnt. 3. De bijzondere voorliefde, die B vertoont voor afleidingen van angkit iplv. het gewone angkat (zie r. 22, 27, 157/18; zelfs 171/34, 205/27 berangkit! en 250, Bnt. 1 goenoeng angkit-angkitan!) is te verklaren uit het koet., waar angkit syn. is van mal. angkat en niet alleen de gespecialiseerde bet. van mal. angkit heeft. Overigens heeft $\mathrm{N}$ slechts eenmaal mengangkit (153/27). $-13 \mathrm{~N}$ als Tnt. $4-16 \mathrm{~N}$ dipatoeanpoen - 18 serilah, 
lees met $\mathrm{N}$ en evenals $211 / 4 / 8$ sarélah; jav. saré, k.i. bij toeroe, is te Tenggarong nog gebruikelijk voor het slapen van vorstelijke personen. Hierbij 206/3, 211/9 en pass. pesaréan, vorstelijke legerstede, ook ,om in te slapen" (van kains), vgl. 210/26, 214/26. - $22 \mathrm{~N}$ maka iplv. makan $-\mathrm{N}$ als Tnt. $5-27 \mathrm{~N}$ als Tnt. 10 (poelak) en $11-28$ berlarih-larihan, $\mathrm{N}$ duidt hier duidelijk de $i$ aan, doch 214/21 wordt voluit berlarah-larahan gespeld, en 207/2 zonder klinkeraanduiding, hetgeen op de laatste uitspraak wijst. De bedoeling schijnt hetzelfde te wezen. Beide vormen komen in de mal. litteratuur voor. Klinkert geeft alleen belarih-larihan ,elkander inschenken, zooals bij e. maaltijd of drinkpartij", af te leiden van jav. larih, terwijl Wilkinson slechts berlarah-larahan, "toasting each other in turn” opgeeft. Te Tenggarong kende men de woorden niet. $-33 \mathrm{~N}$ baik.

\section{2}

$8 \mathrm{~N}$ itoe na Adji - 12 semenang-menangnja, koet. voortdurend winnen, altijd maar winnen. - $14 \mathrm{~N}$ menangnja - $17 \mathrm{v}$. N Soekoedana, vermoedelijk half javaniserend Soekòdana te lezen. - $21 \mathrm{~N}$ kenegerinja $-24 \mathrm{~N}$ berapa $-28 \mathrm{~N}$ als Tnt. $8-30 \mathrm{~N}$ als Tnt. 9 $\mathrm{N}$ jang na orang - 32 agoeng, lees egoeng - 33 moeloe, lees molo, koet. een bepaald soort Chinese potten, zoals de op Plaat IV en V bij Tromp afgebeelde potten. Vgl. 254/6/11/13 emas semolo, een pot (fijn) goud.

\section{3}

1 Vóór minta behoorden aanhalingstekens te staan, te sluiten achter Madjapahit in r. 4. - $\mathrm{N}$ jang na poeroet $-2 \mathrm{~N}$ hendak mandi ( هندقمند , vandaar de lezingen der andere hss.). - $10 \mathrm{~N}$ als Tnt. 4, doch vóór haripoen nog maka. - 18 soegi, lees soegai, koet. kam; 20 bersoegai, zich kammen. - $19 \mathrm{~N}$ laloelah - berlenga, gebruik maken van lenga, koet. klapperolie (vgl. jav. en mal.). - 20 bersoegi, lees bersoegai $-21 \mathrm{~N}$ als Tnt. $8-23 \mathrm{~N}$ als Tnt. $11-24 \mathrm{~N}$ als Tnt. $12-26 \mathrm{~N}$ maka na roemahnja $-30 \mathrm{~N}$ dajang $2 n j a-31 \mathrm{~N}$ als Tnt. 14.

\section{4}

4 amit, jav., is nog in koet. gebruikelijk, bv. patis amit poen, ik vrage beleefd verlof om heen te gaan. Elders heeft de Sal. steeds pamit, 
bv. 133/16, 181/15, 199/32. - 6 loentar, waarom niet lontar? Lontar penjangkahan, lontar pertenoengan, fraaie naam voor „wichelboek"; penjangkahan (I id.; het woord is in $\mathrm{N}$ door vochtwerking onleesbaar) is een deftige uitspraak voor penjangkaan. Vgl.202/34 batjoba2han. -7 kesatoe, de eerste $=$ mal. pertama, geen huidig koet., doch wel bdj. spraakgebruik. - 10 sepenentang mata, ,zover het oog reikt”, mal. sejodjana mata memandang; vgl. Klinkert's opgave djaoeh mata menentang. - $11 \mathrm{~N}$; تنتو اديدالم ; waarschijnlijk is T’s verbetering (noot 6) de juiste. - poelau Koetai is nog in gebruik als syn. van tanah K. 12 dibilangkannja betekent blijkbaar ditimbangkannja - 13 dengan (het tweede in deze regel), koet. metgezel, makker $=$ mal. teman (zie r. 8 v.), tob. dongan id. $-14 \mathrm{~N}$ manoesiakah $-\mathrm{N}$ déwea, waarachter een losse alif staat. $-15 \mathrm{~N}$ als Tnt. $7-17$ djenak, koet. = mal. njenjak, Perak (Wilk.), sd. id. $-19 \mathrm{~N}$ kadedepan iplv. kedapatan; dit is mogelijk een schrijffout of wel een oudere vorm van huidig koet. kedepan (mimpi), een nachtmerrie hebben. - N دي دثكو iplv. dirangkap, waarvoor ongetwijfeld met TK diroengkoep gelezen moet worden, evenals in KV 24. Koet. merongkop, aanvallen, te lijf gaan, in de haren vliegen (van wilde dieren met klauwen en van vrouwen gezegd), bdj. maroengkoep id. - beroeang koening, in $\mathrm{KV} 25$ is het een harimau. - loentoet, $\mathrm{N}$ id., lees hetzij loetoet of lentoet, het koet. woord voor knie. $-20 \mathrm{~N}$ berkeloepoerlah, moet hier spartelen, tegensporrelen betekenen. De gewone vorm is mengeloepoer, gewoonlijk gezegd van kippen, die geslacht worden (vdW en Wilk.), 145/5 van een haan, die zich niet wil laten vangen. - N maka na itoe - Het verschil tussen $B$ en $S$ c.s. (Tnt. 10) is te verklaren uit het feit, dat in $\mathrm{N}$ de woorden maka ada tadjau dibatisnja tidoer in margine zijn ingevoegd, met de angka $r$ als verwijzingsteken, geplaatst zowel bij berkeloepoerlah als na 't eerste tidoer van r. 21. Het laatste, door B gevolgd, staat op de juiste plaats. I als $\mathrm{T}$, doch nog tidoer serta na dibetisnja. - 21 tadjoe, lees tadjau; de pot, waarvan hier sprake is heet in de volksoverlevering tadjau kang, vgl. $\mathrm{KV} 27 .-22 \mathrm{~N}$ keris 23 dibeladaunja; mbeladau, koet. niet alleen steken met een beladau, doch ook met een kris of een ander steekwapen. Hiernaast komen ook afleidingen van het sec. grondwoord ladau voor. Vgl. KV 26 (kerisnja) diladaukannja en 29 kena ladaunja. De kris, waarmee de prins hier steekt, is volgens de overlevering de Boerit Kang (zie 160/15), die 
aan deze episode haar naam ontleent, vgl. KV 28. - tadjoe, lees taljau - 26 gagapahan, te Tenggarong kent men dit niet, wel gelapahan of gegelapahan, zoals $\mathrm{T}$ leest. Dit betekent zenuwachtig (doen). De woorden karena Adji itoe gagapahan worden natuurlijk niet door den prins zelf gezegd, wat de aanhalingstekens suggereren. Het volgende kita kan niet goed zijn, misschien te lezen katanja. - $\mathrm{N}$ als Tnt. 15 $\mathrm{N}$ berkontjang iplv. bergoentjang, naar koet. en bdj. spraakgebruik. 27 roemah pandjang toedjoeh belas, sc. depa. $-28 \mathrm{~N}$ tarék iplv. teriak; seroemahan tarés, koet. het gehele huis, alle bewoners zonder uitzondering. - 29 boedja, lees met Bnt. 18 boedjas - sangkoeh, 227/2, $252 / 33$ id.; sangkoh, koet. speerpunt aan een blaasroer verbonden, dan ook blaasroer met zo'n speerpunt. Zie ook Tromp aant. 30, bl. 78. Vgl. jav. sangkoeh en Wilk. sv. sangkoe III, alwaar de opgave voor ser. moet vervallen, aangezien men daar sangkoh zegt, blijkens een aant. van Moulton op Marshall's br. woordenlijst. De br. uitspraak sangkoe correspondeert met sd. sangko. $-30 \mathrm{~N}$ itoe ontbr. $-31 \mathrm{~N}$ abus. W/, I id. iplv. dinjalaïnja; $-i$ correspondeert in deze vorm met mal. -kan, zoals zo vaak in koet. en bdj., die een zekere voorkeur voor het suff. $-i$ hebben.

\section{5}

$2 \mathrm{~N}$ als Tnt. 1 en $2-3 \mathrm{~N}$, die met orang een nieuwe bladzijde begint, heeft soedah na kira ${ }^{2}$, echter niet in de rakibah. - N maka na meng(h)adap - $6 \mathrm{~N}$ فراجه iplv. fardj; ofschoon B's lezing een psycho-analyticus zou kunnen verrukken, is zij toch onjuist. Mijn helpers lazen hier onmiddellijk peradja, koet. voorteken, dat iemand spoedig zal huwen. Van personen, die maar geen levensgezel(lin) kunnen vinden zegt men wel, dat zij berat peradja zijn. In peradja orang, dat ook 161/12, en daar goed gespeld, voorkomt, slaat orang op de :emand, met wie het ophanden zijnde huwelijk zal worden gesloten. Vgl. md.-mal. peradje, voorteken in het algemeen. $-8 \mathrm{~N}$ tetapi 9 djodo, ook in koet. en bdj. de gewone uitspraak, die veel verbreider is dan het door Van Ophuijsen voorgeschreven djodoh. - 11 agoeng is hier een hoog woord voor besar, groot, volwassen, evenals in 236/4. Vgl. de door Klinkert sv. bawa op gezag van Clifford en Swettenham opgegeven uitdrukking membawa agoeng, ,groot geworden zijn, den volwassen leeftijd bereikt hebben", welke wel geen alg. mal. zal zijn. Zie 
ook 170/21 in een verband, waar elders het taki-woord langgoeng staat. In pararatoe jang agoeng (176/6), balai agoeng (181/18), pajoeng agoeng $(131 / 21)$ e.d. komt het gebruik overeen met het alg. mal., volgens Wilkinson's definitie ,associated with importance more than size". - $27 \mathrm{~N}$ jang na boenji- $29 \mathrm{~N}$ peroléh iplv. beroléh $-31 \mathrm{~N}$ $a d a$ na Ini (bijna onleesbaar door inktveeg). $-32 \mathrm{~N}$ als Tnt. $9-33 \mathrm{~N}$ poelang iplv. poela.

\section{6}

1 pengempoean of kempoean, koet. iemands heer, meester van hoge geboorte. Vgl. ojav. pangemprwan en pangempon. - $4 \mathrm{~N}$ hendak $5 \mathrm{~N}$ als Tnt. $1-6 \mathrm{~N}$ abus. mengirikan iplv. mengiringkan $-8 \mathrm{~N}$ berkelilinglah $-17 \mathrm{~N}$ sigeralah $-20 \mathrm{~N}$ kekanak iplv. het onbestaanbare kekanak-kanak. - $25 \mathrm{~N}$ doea orang na orang (vgl. Tnt.6) $26 \mathrm{~N}$ tampoes iplv. tapoek; Klinkert's opgave sv. tapoek, waaruit men zou opmaken, dat dit syn. van tampoek zou zijn, wordt niet bevestigd door Wilkinson. -27 na moeloetnja geeft $\mathrm{N}$ nog kekanak itoe maka29. $\mathrm{N}$ roepanja maka iplv. tweede roepa orang itoe - 31 dibasaïnja basa radja-radja, spraken zij haar toe in hoge taal, vgl. jav. ambasani. 202/2 membasakan basa Djawa kebasa Melajoe, Javaans in Maleis vertalen, vgl. jav. ambasakaké. - 32 mentjatoe, 157/4, 194/16 en pass. id., koet. en bdj. om iets verzoeken aan een meerdere (201/18, 202/16 $k e($ pada), 202/9 di), vgl. Klinkert sv. tjatoe II (uit Hik. Bandjar). Hiernaast staat mentjatoei in de bet. van aan een mindere iets geven (met dubbel object), zie 201/9, 207/23, 223/28 en pass. ditjatoeï, 202/22, 204/31 andika tjatoeï. Het begrip ,afgepaste portie”, dat aan 't jav. en mal. woord inhaerent is, heeft koet. bdj. tjatoe niet. De verhouding tussen mentjatoe en mentjatoei is dezelfde als tussen jav. neda en nedani (in de zin van amitedani, vgl. Berg, Bijdr. Jav. Ww. 254, noot 2).

\section{7}

$6 \mathrm{~N}$ als Tnt. $3-7$ tadjoe, lees tadjau -8 awak balikkan, vgl. $169 / 30$ v. koebalikkan, 169/27 membalikkan, koet. = mal. mengembalikan, doen terugkeren, teruggeven; bebalik, koet. terugkeren, mal. kembali, vgl. 169/31, 200/23 berbalik. - $12 \mathrm{~N}$ als Tnt. $6-13$ berpadah, 158/9, 243/5, 254/18 id., koet. zeggen, meedelen; 158/7 berpadah-padah, redupl. ter versterking. Hierbij madahkan, koet. iets meedelen, iets zeggen, vgl. 169/5 dipadahkannja. Dezelfde bet. heeft padah 
in bdj. en sd. Vgl. mal. madah (bermadah, memadahkan), welks afleiding van arab. $\tau^{\mu}$, met reserve door vdT in vdW gegeven, nogal geforceerd lijkt, en mal. padah naast pedah, voorteken, karo pedah, toba poda, onderricht. - $14 \mathrm{~N}$ andika na pengandika - $15 \mathrm{~N}$ kekanak - $17 \mathrm{~N}$ dan mengganganlah na mendjeranglah (vgl. Tnt. 8); gangan, koet. bdj. = mal. goelai, sajoer (vgl. $\mathrm{KBW}$ sv.), menggangan, deze bereiden. $-18 \mathrm{~N}$ als Tnt. 10 en $11-19 \mathrm{~N}$ kekanak - 21 id. 23 id. $-28 \mathrm{~N}$ soeatoe $-30 \mathrm{~N}$ kekanak.

\section{8}

3 berkais-kaisan, 180/15, 181/9/25/27, 199/26/29 id., of berkaisan, 180/17, koet. redetwisten, kibbelen. - $4 \mathrm{~N}$ kekanak - 9 menegang, 10 id. ; 24 ditegang ; 26 menegang sebarang tegang; negang, koet. tegenhouden, vasthouden $=$ mal. menahan. Vgl. sd. nagang, ,to restrain, keep back, stop, prevent, forbid." - boedjang landjoean (N لنجوان ), $162 / 6$ id.; vermoedelijk is dit niet de eigenlijke naam van de haan, zoals men mij verklaarde, doch een adatterm, met misschien de bet. „,bezoekende, d.i. niet ter plaatse gevestigde jongeman, doortrekkende vrijgezel"?; vgl. jav. landjon. - $10 \mathrm{~N}$ menegang iplv. menenggang 12 soedah cadatnja manos laki itoe mengiringkan manos bini; deze woorden houden klaarblijkelijk een toespeling in op het matrilocale huwelijk. KV 31 is nog duidelijker; men leest daar in dit verband: cadatnja orang laki-laki mengikoet orang perempoean. - 13 oeloer, 27, 248/30 id.; over dit woord zie Tromp aant. 64 en de wdbn. Hier is bedoeld, dat de haan door te paren met een hen van de prinses, welke deze beschouwt als haar sepangan, is geworden tot haar oeloer, evenals een vrij man door een huwelijk met een vrouwelijke sepangan (zie aant. bij 162/18) zijn vrijheid verliest. De adatspreuk voor het laatste is volgens Tromp benia menerdjoeni poeloet, waarvoor de Sal. (hier r. 15) leest: poenai $m$. p. De eerste lezing vindt men ook in Oend. B.N. fasal 13, waar in de uitgave ten onrechte binia wordt geschreven. Benia, koet. = mal. elang. -15 menardjoeni, lees menerdjoeni $-16 \mathrm{~N}$ kekanak (bis) - 18 id. - N maras iplv. mara, 181/23, 198/29/31, $199 / 2,202 / 8$ id. Dit woord, waarnaar ik te Tenggarong verzuimde behoorlijk te informeren, behoort vermoedelijk tot de hoge taal, en is het litt. jav. marak, zijn opwachting gaan maken. Hs. I spelt op de boven aangehaalde plaatsen أراً (mesaras), wel onder invloed van bdj. 
$m a^{s} a r a k$, dat tot de basa dalam gerekend wordt en dezelfde bet. heeft. $-25 \mathrm{~N}$ itoe na poeteri - $26 \mathrm{~N}$ tiada akoe menegang sebarang tegang iplv. tiadakoe - tenggang; ik houd (die haan) niet zo maar, op willekeurige gronden, vast. Vgl. 213/33 djikalau tiada soeroean dalam tiada berani boebar sebarang boebar, als er geen boodschap van den vorst was gekomen, hadden zij niet zomaar de audiëntieplaats durven verlaten; 214/30 djangan adinda sembah sebarang sembah sadja, je moet maar niet zo in het wilde weg sembahs maken. De constructie, die doet denken aan de figura etymologica der latijnse grammatica (vitam vivere e.d.), spreekt voor zich zelf. Ik geloof echter niet, dat zij algemeen mal. is. Verwant is 228/17 en 230/13: barang pandér dipandérkan (dan) barang goerau digoeraukan, allerlei praat werd gepraat, allerlei scherts werd geschertst, men praatte en schertste honderd uit. Vergelijk ook de niet geheel „logische” wending 194/17 jang patik gégérkan boekan gégér apa-apa, wij maken ons niet druk over iets willekeurigs. $-27 \mathrm{~N}$ als Tnt. $10-28$ lees: menerdjoeni $-29 \mathrm{~N}$ als Tnt. $11-$ $31 \mathrm{~N}$ als Tnt. 12.

\section{9}

$3 \mathrm{~N}$ limau poeroet na adapoen $-5 \mathrm{~N}$ als Tnt. $3-6 \mathrm{~N}$ empoenja - $\mathrm{N}$ tetapi $-7 \mathrm{~N}$ empoenja $-10 \mathrm{~N}$ baiklah $-\mathrm{N}$ als Tnt. 5 $\mathrm{N}$ empoenja - 15 tandjal, koet. flauwgevallen, bewusteloos. Hier schijnt meer sprakeloos van verbazing bedoeld te zijn, doch in $\mathrm{KV} 33$ heeft het duidelijk de eerste bet. in hetzelfde verband. - $17 \mathrm{~N}$ als Tnt. $6-21 \mathrm{~N}$ tinggallah $-22 \mathrm{~N}$ kekanak $-26 \mathrm{~N}$ digaloengnja $32 \mathrm{~N}$ dengan iplv. tweede dan -- N Emas iplv. Mas - $33 \mathrm{~N}$ oengoe mana baik iplv. agoeng menaik (vgl. Tnt. 12 en 13); Kentjana Oengoe (Woengoe) is de naam van Praboe Kenya, vorstin van Madjapait, de vrouwelijke hoofdfiguur uit de Damar Woelan. - N sembahnja.

\section{0}

$1 \mathrm{~N}$ als Tnt. $1-2$ dérva derma déwa digoenoeng toenan; Dérwa Darmadézwa is een door Wisnoe in het leven geroepen figuur uit de Hik. Sang Boma, wonend op de berg Tenoenan, met zijn wonderschone echtgenote Déwi Darmadéwi, die door Brahma was geschapen. De schrijver van de Sal. kende het verhaal blijkbaar niet al te goed en meende, dat Déwa Darmadéwa een vrouw was. -3 toenan, t.r. Tenoenan - N als Tnt. 3 - $5 \mathrm{~N}$ kekanak na sembah (vgl. Tnt. 4) - 
$\mathrm{N}$ ipoen iplv. itoepoen; ,ipoen Adji”, goed, Heer, zeggen de panakawans dus. -8 beboréh, 210/25/29/36 en pass. id. naast 215/24 boréh; de geredupliceerde vorm is niet in koet. gebruikelijk, doch wel in bdj., evenals in batav. en bal. ; 215/24 beboréh, boreh gebruiken; 211/2 memboréhi, met b. insmeren $=$ jav. amborèhi. $-10 \mathrm{~N}$ als Tnt. $6-$ 11 goeringsing, 168/7 en pass. steeds deze spelling. Voor geringsing wajang, g.'s met wajangfiguren, vgl. o.a. J. en P. III, 222, no. 60. Behalve de hier genoemde lakon Pandawadjaja, die in dit verband ook uit de jav. en mal. litteratuur bekend is (zie KBW sv. pandarea en Wilk. sv. geréngséng), vindt men $168 / 8$ een lakon Pandazua Poelang Sah (?) als motief voor een geringsing genoemd, terwijl Sangoepati in 251/3, ook zo voorkomend in de Malat (KBW sv. sangoe 1e), wel eveneens de naam van een lakon zal zijn. - 12 lelakon, 168/8 id., de geredupliceerde vorm is in 't bdj. de gewone, in koet. zegt men echter lakon. - panda wadjaja, lees pandawa-djaja - $14 \mathrm{~N}$ taloe iplv. tiga; koet. teloe $=$ mal. tiga, bdj. taloe. $-15 \mathrm{~N}$ itoe na Boeritkang; Boerit Kang, 256/20 id., een tot de keradjaan van Koetai behorende kris, vgl. Tromp bl. 101, no. 1 en de aant. bij 154/23. - kantjing geloeng, jav. haarspeld (GR), soort van haarsieraad (achter in de haarwrong) (Pigeaud); hier is de letterlijke bet. voorwerp om de haarwrong mee vast te maken nog zeer duidelijk, immers in $r .16 \mathrm{v}$. leest men, dat als de wrong niet met de kris was vastgemaakt (dikantjing), ze zeker niet zou houden, doch losgaan. Elders wordt tjoetjoek geloeng gebruikt in dit verband, zie 131/12. - $16 \mathrm{~N}$ iplv. mangkoer awakal, zie 144/27. - N tida iplv. tiada (komt meermalen voor, doch verder niet gesignaleerd). - $18 \mathrm{~N}$ beroerap ${ }^{2}$ - parang roesak, als onderdeel van de naam van een smeersel mij niet bekend; waarschijnlijk is de bedoeling, dat de oerap-oerap werd geappliceerd in figuren van de vorm van het bekende vorstelijke batik-motief parang roesak. $201 / 8$ komt het in de gewone bet. voor. - 19 baoenja semerbak teroes kedaton, vgl. 169/19 baoenja meneroes kedaton. In een jav. Rengganishs. werd aangetroffen gaganda neroes kadaton. Het in de mal. woordenboeken ontbrekende kedaton vindt men ook 190/2, naast 201/17, $203 / 13,230 / 15$ keraton. Ook in het bdj. en bdj. hss. komt kadaton naast karaton voor. - 20 manda kaki, jav. mandakaki, een plant met geurige bloemen, vgl. de wdbn. en de Clercq no. 2847 en 3828. gegoebahan; jav. goegoebahan, festoen van aaneengeregen bloemblaadjes. - soering pati, lees soeréng pati. Dit is o.a. de naam van een bepaald model van oorkrab. Vgl. Tjan Tjoe Siem, Hoe Koeroepati zich 
zijn vrouw verwerft, bl. 206, noot 51 . Op verschillende plaatsen in de jav. litteratuur en ook hier in de Sal. krijgt men de indruk, dat soerèng pati bepaaldelijk de naam is van de s o o $\mathrm{rt}$ van bloemenvlechtsel (eventueel der bloemen waaruit het bestaat, wat $T \mathrm{jan}$ voor de oorspronkelijke bet. houdt) en niet de naam van de soemping zelf. Vgl. behalve de door Tjan geannoteerde plaats Irawan Rabi $33 / 6$ soemping mas rinéka kananga ginoebah soerèng pati; hs. Bat. Gen. 295, IX, 12 akekoeloek kanigara, asasekar sinoerèng pati, doewoeng tinatoerangga. $-21 \mathrm{~N}$ als Tnt. $13-26 \mathrm{~N}$ als Tnt. 15 - anoetoepi, deze zuiver jav. vorm wordt steeds gebezigd in dit verband, vgl. 195/34, 224/13, 242/9. - 27 bebahan soengoe, lees babahan songo (zelfde plaatsen als bij anoetoepi), jav. babahan sanga, in de jav. litteratuur gewoonlijk $b$. nawa-sanga, de negen lichaamsopeningen. - angembah, lees angambah, jav. begaan, betreden. - djemantera, lees djemantara, litt. jav. djoemantara, 't luchtruim (ook bij Wilk.) - 28 disingsatnja, deze vorm komt niet in de mal. woordenboeken voor. Voor 't jav. vinden wij opgegeven njingseti en njingsetaké in de hier bedoelde zin: strak aanhalen. Zonder suff. echter sas. (njingset) en vgl. Brandes, Beschr. Jav. enz. hss., 3e stuk, bl. 2b, 12 lwir ningset lantjingan manekes ikang roma. -29 simbar dada, jav. s. dada, ruig borsthaar. - dipiling-pilingnja; koet. piling = mal. pilin; vgl. bal. miling, de knevels krullen (KBW). - N برغوسن iplv. beroengoesnja; koet. berengos, snor (jav.).

\section{1}

5 dajang, 11 id., behalve als titel voor vrouwen uit kampong Pandịi en bijvrouwen van den Sultan (Tromp bl. 19) is het ook in gebruik als aanspreektitel tot adellijke jongedames. $-7 \mathrm{~N}$ ahreal iplv. hal ahwalnja - $8 \mathrm{~N}$ jang na kepada - tedoeng ari; koet. tedong a., een onschuldig slangetje, dus niet, zoals ik in Bespr. 309 vermoedde, hetzelfde als mal. tedoeng matahari, welke tot de gifslangen behoort. Terwijl tedoeng in het mal. bepaaldelijk voor gifslangen in gebruik is, evenals tadoeng in het bdj., is tedong in koet. het alg. woord voor slang $=$ mal. oelar. - tedoeng boelan, zou een veel op $t$. ari gelijkend, eveneens onschuldig slangetje zijn. Misschien is het echter slechts een takisyn. van t. ari. - $11 \mathrm{~N}$ jang vóór Baboe - niam, hoewel ook $\mathrm{N}$ uitdrukkelijk تيمّ spelt, zal ném bedoeld zijn, jav. nèm, kr. bij nom, jong. - 12 Iplv. andika moet misschien mimpi andika gelezen worden, 
vgl. 155/6: - $15 \mathrm{~N}$ enja iplv. inja - dipatoet-patoetkan; koet. matoetkan betekent eigenlijk: iets bij gebrek aan het passende instrument maar bezigen voor een doel, waarvoor het niet bestemd is. Ten aanzien van personen kan men het weergeven met: over iemands toekomst praten, als iets vaststaands, ofschoon er in werkelijkheid niets van bekend is, ongeveer zoals ons "doodverven”. - $23 \mathrm{~N}$ mangkin iplv. makin (bis) - 31 berganti bekas, koet. op de plaats van een ander gaan zitten, bdj. baganti bakas id. Vgl. Hik. Sri Rama Maxw. 31/2 ... kelakoean Kera Ketjik menggantikan bekas keradjaan itoe, „hoe K. K. was gaan zitten op de troon van den vorst" en ib. r. 4 adapoen tempat keradjaan soedah digantikan oléh kera, ,een aap is gaan zitten op de troon van den vorst." - $35 \mathrm{~N}$ Djaroema itoepoen - $36 \mathrm{~N}$ serta na isteri.

\section{2}

$2 \mathrm{~N}$ mandja iplv. mendjadi; mandja betekent in koet. en bdj. niet alleen „verwend”, doch ook vriendelijk, met goede bedoelingen. $6 \mathrm{~N}$ itoe na itoe - كوغر iplv. 't juiste koedengar - $7 \mathrm{~N}$ rantjah; de bet. ontgaat mij. - N Edjoeng iplv. Oedjoeng $-10 \mathrm{~N}$ als Tnt. 3 en 4-11 tekatan, 14 id., borduurwerk, borduursel; de vorm ontbreekt in de wdbn. - $15 \mathrm{~N}$ empoenja - N برفديلد. iplv. berpandilah; de lezing van T en K (berpandirlah) is te vlak. Vgl. 254/5 برفديا als syn. van berboeat cakal. Ook hier past de bet. ,een list verzinnen, jokken" uitstekend. Vermoedelijk moet berpedaja gelezen worden, een vorm van welks voorkomen in de litteratuur of spreektaal ik geen bevestiging heb kunnen vinden, doch vgl. mal. memperdaja en teperdaja. Ook $142 / 20$ zou ik bepedaja willen lezen iplv. bepadah ia. - 16 hilang, heeft in 't koet. behalve de gewone ook de bet. van uit, uit(ge)gaan, niet thuis. Zo kan hier hilang ketepian worden weergegeven met ,naar achteren" en 208/12/16 radja itoe hilang met "de vorst is niet aanwezig". Vgl. bdj. basélang, op bezoek gaan (masélangi, bezoeken), dat oorspronkelijk wel „van huis zijn" zal hebben betekend. $-17 \mathrm{~N}$ enja iplv. ia. - 18 sepangan, koet. iemand, die tot oeloer is gemaakt of zijn nakomelingen, slaaf van den vorst. Het verschil tussen oeloer en sepangan is, dat de eerste door den Vorst om een of ander misdrijf van zijn vrijheid is beroofd, terwijl sepangan in het algemeen horige van den vorst, dus zowel krachtens afstamming als doordat hij tot oeloer is gemaakt, betekent. Zie Tromp aant. 64, en vgl. sapangan of sepangan 
op Bali en Lombok. In bdj. heeft sapangan de bet. van iemand, met wie men ongeoorloofde liefdesbetrekkingen onderhoudt, zowel liefje, boel als schandknaap. - $\mathrm{Na}$ itoe behoren de aanhalingstekens gesloten te worden. $-19 \mathrm{~N}$ als Tnt. $7-\mathrm{N}$ abus. tjarinja $-22 \mathrm{~N}$ als Tnt. 8$23 \mathrm{~N}$ baboekoe baboekoe iplv. éénmaal. $-24 \mathrm{~N}$ tama iplv. tamas; tama, koet. binnengaan $=$ mal. masoek $;$ namakan $=$ mal. memasoek kan; namaï = mal. memasoeki. Vgl. 199/21/23 adinda tamakan (opsteken van een kris), 174/8 ditamaïnja, begaf hij zich erin. Voor de etymologie zie KBW sv. tamas. - $32 \mathrm{~N}$ tetapi - baiklah konon poela jang njata maka tiada koelihat, laat staan, dat ik niet zou zien wat zichtbaar is ....

\section{3}

$1 \mathrm{~N}$ empoenja -2 id. -5 pengrasa, koet. = mal. perasaan, vgl. jav. - 7 setipoe-dajakoe, met alle mij ten dienste staande middelen, vgl. in een aanhaling uit een Bataviase redactie van de Si Miskin: „baik kita bikin onar satipoe daja kita sopaja binasa karadjaännja" (vdT in Homan, Handleiding t.d.k. van 't Bataviasch Maleisch, bl. 81) $8 \mathrm{~N}$ Sizva-9N N w , sepeneda, iplv. sepenoeh-penoeh, vgl. Tnt. 2. - $14 \mathrm{~N}$ itoe ontbr. - $\mathrm{N}$ boeboeskah - $\mathrm{N}$ didalam - $15 \mathrm{~N}$ hati $16 \mathrm{~N}$ tjitanjalah iplv. tjintanjalah, lees di- $-18 \mathrm{~N}$ ia na masoeklah $22 \mathrm{~N}$ als Tnt. $3-23 \mathrm{~N}$ larilah $-27 \mathrm{~N}$ dibarwas $-32 \mathrm{~N}$ maka ontbr. $-35 \mathrm{~N}$ boekan.

\section{4}

$1 \mathrm{~N}$ als Tnt. 1, alleen ontbr. kepada en maka $-4 \mathrm{~N}$ als Tnt. $3-$ $8 \mathrm{~N}$ als Tnt. $5-10 \mathrm{~N}$ als Tnt. $6-12 \mathrm{~N}$ bertjaritalah $-13 \mathrm{~N}$ itoe na Djaroema $-21 \mathrm{~N}$ spelt mesaoeratlah iplv. moesjawaratlah $-22 \mathrm{v}$. pendjoedjoe, 26 id., niet meer gangbare adatterm voor, zoals hier blijkt, een vorstelijk huwelijksaanzoek, waarbij tegelijkertijd de bruidschat wordt bepaald (vgl. mal. djoedjoer). Pasang pendjoedjoe was blijkbaar de technische term voor het vervullen van het huwelijksaanzoeksceremonieel. 233/4 wordt bependjoedjoe in één adem genoemd met het

brengen van de patiban sampir. $-24 \mathrm{~N}$ als Tnt. $10-25 \mathrm{~N}$ مستعبله iplv. moestacid, vgl. Tnt. 11, 180/11, 195/30, 231/26, lees moestaciblah. Het is een gewone verbastering van moestacid, welke veel in mal. hss. wordt aangetroffen, vgl. ook Van Ophuijsen, Mal. Spraakkunst bl. 35. 
In de wdbn. ontbreekt zij. - فنكيران iplv. pinggiliran (vgl. Tnt. 14), t.r. penggiliran. Penggiliran mata is, zoals uit de tekst blijkt, het eerste geschenk, dat bij het huwelijksaanzoek wordt aangeboden, en dat a.h.w. dienen moet om de ogen van de vertegenwoordigster der bruid tot zich te doen wenden, bestaande uit een stuk goud ter grootte van een batoe anting. In het eerste (in een door mij te Tenggarong geraadpleegd hs. was het het tweede) toevoegsel op de Oend. B.N., dat over de berekening van de bruidschat voor vorstendochters handelt (vgl. Van Ronkel, Het Adatwetboek van Koetai, bl. 161 vv.), bestaat de penggiliran mata uit gong berantai selindoeng doedoek (vgl. Sal. 233/12), ter waarde van vier orang. Met dit laatste woord zijn slaven bedoeld. Zoals later in hetzelfde geschrift wordt opgegeven staat de waarde van één orang gelijk aan 20 réal, d.i. tegenwoordig 40 gulden. - $30 \mathrm{~N}$ berkata iplv. berkata-kata $-\mathrm{N}$ disorong nja.

\section{5}

1 pemboeka moeloet, wederom een geschenk bij het huwelijksaanzoek, zoals de tekst aangeeft ten doel hebbende de vertegenwoordigster der bruid aan het spreken te krijgen. Hier wordt als waarde opgegeven $11 / 4$ tail goud. In Toev. Oend. B. N. bestaat het daar pemboekaan moeloet genoemde geschenk uit een bedil benaga angkatan orang toedjoeh, d.i. een kanon met handvaten in naga-vorm, dat door zeven man getild kan worden, gelijkstaande aan een waarde van zeven orang, dus 140 reaal. - $\mathrm{N}$ soeroean iplv. soeroehan, blijkbaar naar de uitspraak, 213/33 id. - 2 de volgende passage bevat de conversatie tussen de vertegenwoordigers der twee partijen in taki-vorm, vol figuurlijke, niet alle even duidelijke zegswijzen. - $\mathrm{N}$ als Tnt. 1, alwaar men leze njaï. - 3 mengapang? Men stelde mij voor te lezen menggepang, wat omarmen zou betekenen (?). - $4 \mathrm{v}$. dikajoe, ook $\mathrm{N}$ heeft dit en niet „dikeliwa” als T. Mijn voorstel in Bespr. 306 om hiervoor dikeliau te lezen moet ik in verband met N's volkomen duidelijke lezing intrekken. - 8 v. pendjarat, t.r. pendjerat; ndjerat, koet. vastbinden, bdj. mandjarat id., dus anders dan mal. mendjerat. - 9 djamban hanjoet, men bedenke, dat in deze streken de meeste djambans op een vlotje zijn gebouwd.-Iplv.djala-djala zou ik willen lezen : djala,djala, evenzo in de volgende regel. De bet. is dan: „Verzoeke een werpnet, een garen werpnet, Verzoeke een werpnet, een zijden werpnet." - $10 \mathrm{~N}$ djala iplv. het tweede djala-djala - 11 ranggi, lees rénggé, koet. bdj. een soort sleepnet voor het vangen van zeevissen. Hier wordt het gebruikt als een dichter- 
lijk syn. van djala, dat natuurlijk evenzeer figuurlijk bedoeld is. $\mathrm{N}$ njai na oléh - 12 lading, koet. bdj. = mal. pisau (jav.) - penjangga darah, zou penoenggoe darah betekenen, doch hoe het aan die bet. kwam kon men mij niet precies uitleggen. - 13 lantjang, koet. een riviervissoort. - De bedoeling van 12-14 is : evenals een mes om bloed te proeven moet wachten, tot men er een wonde mee toebrengt, en evenals de lantjang onder de djamban moet wachten, totdat het de mens behaagt wat te laten vallen, zo moet ook een meisje wachten, tot er een man om haar hand komt vragen. Vgl. de bekende uitdrukking pahat menanti poekoel, die in hetzelfde verband wordt gebezigd. 17 goegoeri is blijkbaar een dichterlijk woord voor „opleggen”. Goegoer is ongeveer, en in het bdj. geheel syn. van djatoeh. Vgl. mal. mendjatoehkan hoekoem, een vonnis vellen. De bedoeling van de zin is duidelijk: „Verzoeke ons te zeggen, wat wij verschuldigd zijn”, met andere woorden: deel ons mede, wat als bruidschat wordt verlangd. barih, vdW sv. baréh: ,schuld die men maakt, door geld te leenen of op crediet te koopen. Het staat gew. ter versterking na oetang”, Wilk.: „Debt (due to an actual loan). Stronger than hutang (indebtedness of any sort)." Het woord is zo zeldzaam, dat Klinkert de juistheid der opgave van vdW ontkende. In de mij ter beschikking staande adatlitteratuur ontbreekt het, evenals in de meeste mal. woordenboeken. Hier is

het taki-syn. van oetang. - $18 \mathrm{~N}$ سرسه . In Toev. Oend B.N. wordt gesproken van een kain tjelari ter waarde van 2 orang. De opsomming van de verschuldigde voorwerpen daar en die in de Sal. lopen sterk uiteen. - saboek petola, in Toev. Oend. B.N. wordt genoemd: petola sehelai berbenang mas ter waarde van 3 orang. - tadjoe, lees tadjau lingoe, moet volgens mijn helpers lingau gelezen worden, doch zij konden mij niet zeggen, hoe een zodanige pot er uitzag. Uit de samenstelling van de bruidschat ziet men duidelijk, hoe in vroeger tijden onder de Koetainezen Chinees aardewerk dezelfde functie van beleggings- en betaalmiddel heeft vervuld, die het thans nog bij verschillende Dajakse stammen heeft. - $19 \mathrm{~N}$ als Tnt. 10; de uitspraak is pinggan memorong volgens mijn helpers, vgl. mal. jav. morong, een soort van pot. $\mathrm{N}$ ك gantar, misschien te lezen genggam gentar of gantar? De bet. is onbekend. Gantar is de naam van een muziekinstrument, bestaande uit een stok met een bamboekoker aan het eind, waarin harde pitten bij schudden van de stok een rammelend geluid geven; het wordt door 
Toendjoengs, Benoea's en Bentians bij de dans gebezigd (vgl. Witkamp, TAG 1925, bl. 21). Het kan zijn, dat dit hier bedoeld is. In een plechtige optocht zouden danseressen met deze stokken niet misstaan. Een mijner helpers wil hier genggam boenoeh lezen, wat de koet. uitdrukking voor akil balig is. Doch ook in het Toev. Oend. B.N. vindt men hetzelfde woord. Hier wordt het aantal dezer lieden niet op veertig, doch op twee en dertig bepaald. Naast hen worden 32 personen genoemd, die de wisselkleren voor de bruid aanbrengen. Zijn dit misschien de 3 ركن van r. 19, waarvan de Sal. er weer veertig noemt? - 21 orangnja satoe negeri? - tadjoe, lees tadjau - 22 nagang, 233/11 id., het model is onbekend. - pinggan sangkar, koet. wit porseleinen bord zonder versiering. - 23 tadjoe, lees tadjau - N كثלخ iplv. ganggang, bet.? - 24 rantai zou ranti moeten worden uitgesproken, doch het model is weerom onbekend. - $\mathrm{N}$ keradjat iplv. kerdjat - seriboe, sc. réal. In Toev. Oend. B.N. komt men tot een eindsom van 1970 réal. $-25 \mathrm{~N}$ als Tnt. $12-27$ soemahan, 174/20, 183/18 vv., 244/26 id., koet. bruidschat; vgl. het Berause soema (Adatrechtbundel XIII, 84 naar van Walchren). - didjadjarlah di Tepian Batoe laloe ke $(H)$ Oeloe Doesoen, in een rij opgesteld van Tepian B. tot Oe. D., namelijk de voorwerpen, die de bruidschat uitmaakten. Vgl. KV 52, waar door Adji Bedarah Poetih (Padoeka Soeri) als bruidschat wordt verlangd: tadjau toeha didjadjarkan toelas di Koetai Lama sampai kemoehara Bengalon! - 28 p.m.pak, waarschijnlijk wel het jav. pemapag, zeker geschenk van bruidegom aan bruid of van deze aan den bruidegom (GR). $\mathrm{N}$ سدد iplv. sedaka; sededak sepangajoeh, jav. sadedeg-penggajoeh (in Bespr. 307 abus. sepengajoeh), .,,de hoogte, die een man staande met omhoog gestrekten arm kan bereiken" (GR). $-31 \mathrm{~N}$ als Tnt. 15, behalve dat doea ontbr. - 32 batoeran, ook basatoeran uitgesproken, koet. hoog woord voor eten. - loeloe, 166/1 id., koet. verzamelnaam voor viervoetige landdieren. - soempitan, hier niet de gewone bet. doch "met het blaasroer geschoten, disoempit”.

\section{6}

$3 \mathrm{~N}$ goegoerlah -4 mampi (of mampai) is onbekend. Ongetwijfeld zal koempai gelezen moeten worden, zoals het in de mondeling in omloop zijnde legende luidt. Vgl. de weergave van Tromp bl. 8, waar ook 
het in de tekst niet voorkomende pantai wordt genoemd. Koempar, $180 / 1$ id., is in het koet. een verzamelnaam voor allerlei grassoorten, groeiende aan de oever van rivieren en tevens de naam voor de drijvende vegetatie in het merengebied (vgl. Endert Exp. bl. 207, 209 vv.) - $\mathrm{N}$ als Tnt. $2-8$ karena tanah itoe tinggi sendirinja, „omdat de grond daar van nature hoog was", dus niet door mensenhand opgehoogd (vgl. 226/28). Men wijst thans nog als de plaats, waar vroeger de kraton moet hebben gestaan, een heuveltje bij Koetai Lama aan, dat blijkens verschillende oudheidkundige vondsten hoogstwaarschijnlijk ook de plaats van een Hindoenederzetting is geweest (vgl. Oudheidkundig Verslag 1940, bl. 32). - $11 \mathrm{~N}$ itoe iplv. itoepoen - 15 Padoeka Nira. KV 53 noemt hem Padoeka Ningra, gewoonlijk echter Adji Beramboet Kawat, in overeenstemming met de volksoverlevering (KV 42). $-16 \mathrm{~N}$ Benaloe - $19 \mathrm{~N}$ enjapoen iplv. iapoen - $23 \mathrm{~N}$ beroelang - $24 \mathrm{~N}$ als Tnt. 9 - $26 \mathrm{~N}$ برمو كك iplv. moeka-moeka, in de volgende regel gespeld برمو كان. . Vroeger (Bespr. 306) meende ik met stelligheid, dat T's lezing bermaoek-maoek (koet. maos $=$ mal. maboek) de juiste was. Waar echter 167/21 (zie aant. daarbij) gesproken wordt van berlakoe moeda is het waarschijnlijker, dat bermoekah ${ }^{2}$ gelezen moet worden, hoewel het ontbreken van de eind- $h$ in het hs. vreemd blijft. $-27 \mathrm{~N}$ bersangkoel iplv. bersanggoel; koet. besangkoel, ontkennen, loochenen = mal. menjangkal. $-32 \mathrm{~N}$ als Tnt. 12 ; toenggangan, jav. rijdier.

\section{7}

6 tiada tahoe betekent hier "nooit" = jav. ora taoe. Men zegt in koet. naar het schijnt wel eens éhés taoe, doch gewoner is ndis biasa. $-8 \mathrm{~N}$ enja telah na be(r)langirlah (vgl. Tnt. 5) - $9 \mathrm{~N}$ laloe 11 mengirimkan, koet. toevertrouwen (jav. nitipaké), evenzo 167/28 berkirimkan; vgl. Kelantan kirim ,entrust” (Wilk.), bdj. bakirim = min. bakirin. - $\mathrm{N}$ anak iplv. anakkoe - 14 didjampinja, 23 v. id. djampi, koet. reeds gekauwde, doch nog niet uiteengevallen sirihpruim, die men ter verkoeling op iemands voorhoofd appliceert; ndjampi, deze handeling aan iemand verrichten. - $17 \mathrm{vv}$. Het verhaal van de bezwering, door de prinses toegepast, is klaarblijkelijk in de war. $\mathrm{Zij}$ neemt immers beras majang, korrels van de pinangbloeiwijze, en kookt die, zeggend : wanneer de Adji zich misdraagt in Madjapait, word dan weer majang. Echter trekt zij uit het feit, dat het gekookte tot beras 
wordt, de conclusie, dat haar vermoeden inderdaad juist is. Daarna schept zij de nasi uit de rijstpot en geeft die haar kind te eten. Vermoedelijk is in het bezweringsformulier iets uitgevallen, en hield dit ongeveer het volgende in: Wanneer de Adji zich werkelijk misdraagt in M., word dan rijst, doch als het niet zo is, keer dan tot je oorspronkelijke toestand terug. Het woord beras in r. 20 is dan niet geheel juist gebruikt, doch zou eigenlijk nasi moeten luiden, zoals in r. 22, maar het is te verklaren uit de bedoeling het te stellen tegenover beras majang. „Nasi majang" bestaat immers niet. - 21 berlakoe moeda zal wel hetzelfde betekenen als mal. (ber)main moeda, min. main moedo en bamoedo. Volgens Wilkinson zou main moeda niet bepaald op ,illicit intercourse" behoeven te wijzen, doch voor de min. woorden wordt als vertaling mal. bermoekah opgegeven. - $31 \mathrm{v}$. De opdracht van de prinses om haar kind, als het schreit, in een pot te doen, vindt men $170 / 15 \mathrm{vv}$. ten uitvoer gebracht. Het schijnt, dat hier zeker verband wordt gelegd tussen deze eigenaardige methode om het kindje te sussen en zijn latere bijzetting in een pot. Het bijzetten van doden of hun gebeente in potten is, zoals men weet, in Borneo zeer verbreid. Batara Agoeng Padoeka Nira is onder de Koetaise vorsten de eerste, die op deze wijze is bijgezet, en daarom is zijn posthume naam. Adji Didalam Tadjau (zie 186/6). Misschien is het verhaal omtrent zijn prille jeugd onder het volk ontstaan, toen de herinnering aan het bijzetten in potten was verdwenen, en men behoefte voelde aan een verklaring van zijn naam. In KV 44 hoeft men het kind slechts in de pot te laten kijken, het er niet in te stoppen: toendoekkanlah kedalam tadjan ini. $-34 \mathrm{~N}$ anjoetkan iplv. dihanjoetkan. Het verbod om de lijken van de nakomelingen der prinses te verbranden of met de stroom te laten afdrijven maakt het waarschijnlijk, dat beide bijzettingsmethoden in Koetai in zwang zijn geweest. Vermoedelijk is het verhaal van de wonderbaarlijke verdwijning van de prinses (168/25 vv.) en later van haar echtgenoot $(170 / 8 \mathrm{vv}$.) op een versierde balai met prauw (bedoeld is waarschijnlijk een balai op een prauw) de neerslag van het in werkelijkheid plaats gehad hebbende aan de rivier toevertrouwen hunner lijken. Waarom men van deze bijzettingsmethode is afgestapt wordt in 186/1-3 nader gemotiveerd met het argument „(De dode) kan (of mag) niet meer leven, aangezien degeen, die in leven hield, is bedrogen". Waarop dit slaat ontgaat mij. 


\section{8}

$2 \mathrm{~N}$ als Tnt. $1-3$ bekerdjakah atau bekerdja barang soeatoenja; het eerste bekerdja zal wel bepaaldelijk op het dodenceremonieel doelen. $-\mathrm{N}$ als Tnt. $3-5 \mathrm{~N}$ laloelah iplv. loelat (vgl. Tnt. 5) - $7 \mathrm{~N}$ pakaian$n j a-8$ lelakoe, B in slaafse navolging van $\mathrm{N}$ لالكو; natuurlijk is T's lezing lelakon de goede. - poelang sah? - $\mathrm{N}$ poléng iplv. poelangi - 9 bintaloe, $\mathrm{N}$ بنتل lees met T bintoeloe - 10 ganda simpoel, wel te lezen $g$. sémpol; sèmpol, jav. = gandasoeli. $-11 \mathrm{~N}$ benaloe dipoetiknja, vgl. 212/7 memoetik; koet. bdj. plukken = mal. memetik. $-12 \mathrm{~N}$ tjoetjoe $-16 \mathrm{~N}$ als Tnt. $14-19$ radja jang memoetar. sc. djagat of iets dergelijks. De Sal. geeft de ongebruikelijke uitdrukkingen memoetar kedaton (190/2) en memoetar negeri (205/2). De laatste ook in Oend. B.N. fasal 46. - $20 \mathrm{~N}$ banjak - $21 \mathrm{~N}$ als Tnt. 17 - priaji, 24 id., lees paranjaï?; zie 206/17. - kebandan lepas, 25 id., kon men mij niet verklaren. Wel kende men kemban lepas, een losse, d.i. niet genaaide of met de einden aaneengeknoopte slendang. Mees geeft in zijn „Verklaring van enige woorden” kebandan weer met kain, helaas als gewoonlijk zonder vermelding van de bron. $-30 \mathrm{~N}$ bekerdja piasan iplv. berkerdja perisan (sic, lees periasan).

\section{9}

3 v. padoeraksa, door N gespeld فدورأسا (voor de uitspraak vgl. massoed, 198/26); jav. (buiten)hoek van de muur; hier zal echter eerder de poort van de kraton bedoeld zijn. $-4 \mathrm{~N}$ ia na eerste laloe $-5 \mathrm{~N}$ als Tnt. 4-6 N andika ontbr. - masoena; $\mathrm{N}$ had eerst مسو , wat niet erg duidelijk verbeterd is in L. moesna, 229/27 id., litt. jav. verdwenen. $-8 \mathrm{~N}$ anakanda - 11 tengadah, lees menangislah of tangislah. $-13 \mathrm{~N}$ menjesalkan iplv. menjesal akan - $16 \mathrm{~N}$ tjindai (koet. uitspraak tjindé) iplv. djandi $-\mathrm{N}$ als Tnt. $8-17 \mathrm{~N}$ als Tnt. 10 - $18 \mathrm{~N}$ sidjajéng als Bnt. $11-27 \mathrm{~N}$ als Tnt. 13.

170

$2 \mathrm{~N}$ als Tnt. 1 en 2 (ranik) $-10 \mathrm{~N}$ als Tnt. $3-20 \mathrm{~N}$ mangkin iplv. makin $-21 \mathrm{~N}$ als Tnt. $6-23 \mathrm{~N}$ als Tnt. $7-27 \mathrm{~N}$ als Tnt. $8-$ $29 \mathrm{~N}$ itoe na djaoeh-djaoeh $-31 \mathrm{~N}$ als Tnt. $9-32 \mathrm{~N}$ als Tnt. 10 en 11 . 
$3 \mathrm{~N}$ als Tnt. 1 en $2-4 \mathrm{~N}$ makan-makanan $-5 \mathrm{~N}$ toeas menelaga iplv. manalagi $-\mathrm{N}$ als Tnt. $3-12 \mathrm{~N}$ als Tnt. $4-15 \mathrm{~N}$ goerda moengkoer iplv. garoeda mengkoer $-16 \mathrm{~N}$ als Tnt. $9-22 \mathrm{~N}$ als Tnt. $11-24 \mathrm{~N}$ itoe ontbr. $-25 \mathrm{~N}$ ampar iplv. hamparan $-27 \mathrm{~N}$ orang ontbr. -28 dipelas, 229/12 id. Pelas wordt beschouwd als syn. van tepoeng tawar in het érau-ceremonieel. Zie de beschrijving van Tromp, aant. 30 en vgl. hier aant. bij 126/6. De eigenlijke betekenis van het woord pelas zal wel zijn reinigen, opheffen of voorkomen van een gevaarlijke toestand, en wel eigenlijk door besprenkeling met bloed. Men ontkent te Tenggarong ten stelligste, en ook Tromp maakt er geen melding van, dat bij de ceremonie bloed te pas zou komen. Dit kan vroeger echter wel anders geweest zijn. Men vergelijke het bdj. mamalas, ritueel reinigen door besprenkeling of besmering met bloed $(=\mathrm{ng}$. $s a k i$, vgl. Hardeland sv. palas) of althans een met bloed vermengde vloeistof. Dat in het koet. pelas het verband met bloed nog niet geheel verloren is gegaan, blijkt uit Oend. B. N. fasal 52, waar men leest, dat het bloed van lieden, die incest hebben bedreven, dipelaskan kematahari dan segala kajoe-kajoean (lezing hs. Tengg.) dan keboemi. Vermoedelijk vindt men hetzelfde woord terug in boes. mela, ritueel reinigen, o.a. door bestrijking met in bloed gedoopte bladeren, waarbij zij opgemerkt, dat eind-s in deze taal gemeenlijk wegvalt (vgl. baha, beras, beti, voet, nangi, wenen, e.d.). Barth brengt het woord, niet zonder aarzeling, met $l a$, huid, in verband. Van dezelfde stam zal ook sd. plasi moeten worden afgeleid, in het woordenboek verklaard met „,fine which when paid is supposed to avert the evil that would surely have been brought upon a country through the commission of some such offence as bigamy", waar de boete wel in plaats is gekomen van drastischer maatregelen. Trouwens, mlasi menoa (vgl. bdj. mamalas banoea!) wordt in hetzelfde artikel weergegeven met ,purging the country”, en hoe dat plaats heeft vernemen wij gedeeltelijk van Brooke Low (bij Ling Roth, I, 401), waar van de Sea Dyaks wordt meegedeeld, dat bij ongewoon lang aanhoudende regens, die een teken zijn van de bezoedeling van de stam door een of andere ,impurity”, de oudsten ,get to work to find it out, and adjudicate on all cases of incest and bigamy, and purify the earth with the blood of pigs." $-34 \mathrm{~N}$ als Tnt. 13. 
$1 \mathrm{~N}$ als Tnt. $1-4$ petoeng, 11 v., 173/13 v. en pass. id.; (boeloeh) petong, koet. een bamboesoort, $=$ mal. betoeng, jav. petoeng. 5 Padoeka Soeri heet in de volksmond gewoonlijk Adji Bedarah Poetih, zoals in KV 49, daar zij wit bloed had, hetgeen ook hier r. 13 vermeld staat. - $10 \mathrm{~N}$ als Tnt. 2 - 12 oentjal, 174/11, 175/17, 179/26 id. Dit voorwerp, dat deel uitmaakt van de Koetaise keradjaan, beschrijft Tromp aant.159, bl.101, 3e. als een ,holle opengewerkte gouden cilinder omstreeks 8 centimeter lang versierd met Hindoe-figuren, eene jacht voorstellende, waarin onder meer een Centaur door iemand met pijl en boog wordt doorschoten", waarna naar de Platen I en V wordt verwezen. Een foto van het voorwerp vindt men in Midden-Oost-BorneoExpeditie bl. 420, en wel dezelfde zijde vertonend als Tromp's Plaat V. Op deze zijde ziet men links een hert, rechts twee staande mannen met wajang-hoofdtooi (vgl. o.c. 402 ,zuiver-Javaansche wajang-figuren”), en in het midden, minder duidelijk, een zittende vrouwenfiguur. De andere, niet afgebeelde zijde vertoont een hert met monsterkop (de „Centaur" van Tromp), getroffen door een pijl, en twee mannenfiguren als boven, waarvan de voorste een boog in de hand heeft. De verklaring ligt voor de hand: a) Rama, Laksamana en Sita zien het gouden hert; b) Rama (Laksamana hoort er eigenlijk niet bij) doodt het hert, dat zich in de raksasa Maritja verandert. Volgens Von Dewall (Ind. Arch. 1e jrg., dl. I, bl. 93), die het beschrijft als een ,gouden, koffervormig, voorwerp ...., op hetwelk verschillende mythologische figuren uit de Hindoe-religie, en haut-relief, afgebeeld zijn", is het afkomstig uit de ruines te Moearakaman. Dat het, zoals hij beweert, eerst tijdens de regering van Sultan Moehammad Salihoeddin gevonden zou zijn, is met het oog op de vermelding ervan in de Salasilah al zeer onwaarschijnlijk. In jav. wajangteksten komt oentjal meermalen voor als de naam van een kledingstuk; er is daar echter iets anders mee bedoeld, vgl. Bab Natah, afb. 13, no. 16 (oentjal wastra) en no. 18 (oentjal kantjana). $-13 \mathrm{~N}$ ditangannja - $16 \mathrm{~N}$ als Tnt. $3-20$ Bengalon, vgl. Tromp aant. 31 ; op de internationale kaart Boengaloen. - 21 Mengkanjing? - N مراكو iplv. Meragoei, 25 en elders id., doch soms ook als B; de $i$ is enige malen later toegevoegd. N's lezing verklaart enigermate de lezing Merakap in Tromp's inhoudsopgave. In de tekst wordt niet met zoveel woorden gezegd, dat deze oude man een Basap was, zoals de overlevering luidt. Uit de ligging van zijn woon- 
plaats was dat trouwens voor Koetaise lezers voldoende duidelijk. De Sedjarah Noesentara, die Meragoei niet bij name noemt, spreekt van hem als een „kepala bangsa Basaf” (sic, bl. 144). Voor de verhouding van het Sultanaat tot de Basaps zijn de Basapse connecties van een der voorvaderen van het vorstenhuis natuurlijk niet zonder belang. $22 \mathrm{~N}$. bini iplv. isteri - N ia na hasratnja - 23 dedoekoen, huidig koet. doekoen, bdj. dadoekoen - $27 \mathrm{~N}$ Meragoepoen - 28 kaloek sepit, koet. kelos sepit, krom als een sepit, een aardige simile voor een oudje, dat zo krom is, dat het als het ware met de neus op de grond loopt. 30 balas, t.r. belas - 33 disalaknja ; koet. njalas is ook transitief, ,aanblaffen", evenals bdj. manjalak, sd. njalak. - 34 koejoek, 173/7 en pass. id.; koet. $k o j o^{s}$ is het gewone woord voor hond = mal. andjing; vgl. de woordenboeken. - $\mathrm{N}$ itoe ontbr. - De aanhalingstekens behoren te worden gesloten na bini.

\section{3}

$2 \mathrm{~N}$ als Tnt. 1 - menoetoek, $174 / 3$ id., koet. bdj. stampen van padi of sirihpruim (zoals tandeloze oude lieden doen) $=$ mal. menoemboek. - 4 menggerak, koet. wekken, = mal. membangoenkan, bdj. manggarak. - $10 \mathrm{~N}$ ممارواغي iplv. meraoengi, 175/4-id. Dit zou volgens mijn helpers meroeangi moeten zijn bij meroeang, koet. keffen, een bepaalde wijze van blaffen, die een jachthond te horen geeft, als hij een prooi heeft opgespeurd (?). - $13 \mathrm{~N}$ رابع iplv. reboeng, en zo in de volgende regel سارابع iplv. serabang, vgl. 174/4/8 (N ربق ) 175/4 (N دابق ) ; koet. rebas, stoel (bamboe) = mal. roempoen; sereba ${ }^{\text {s }}$ $=$ mal. seroempoen. $-17 \mathrm{~N}$ ia na ingatlah $-\mathrm{N}$ berboeatlah $-\mathrm{N}$ فخسن iplv. pengasan, 175/7 id. Van dit woord kon men mij uitspraak noch betekenis meedelen. Uit het verband kan men opmaken, dat het tijdelijk hutje, afdakje om te overnachten of iets dergelijks betekent, terwijl de spelling de uitspraak pangsan of pengsan suggereert. Het is blijkbaar hetzelfde als bp. pasan, hut op het veld. $-18 \mathrm{~N}$ als Tnt. $4-20 \mathrm{~N}$ berkalang 2 maka iplv. maka bergalang (vgl. Tnt. 5); berkalang-kalang, koet. liggen op los neergelegde stammetjes bij wijze van geïmproviseerde legerstede. $-21 \mathrm{~N}$ berbaringlah $-\mathrm{N}$ bini iplv. isteri -22 id. $-23 \mathrm{~N}$ als Tnt. $6-24 \mathrm{~N}$ als Tnt. $7-25$ pindjoeng, 
175/9 (Tnt. 6), 206/19 id.; Tromp aant. 159, bl. 98 „,gele sĕlendang .... door drager of draagster om den middel geslagen met het uiteinde om den vinger gewonden", behoort tot de pangkon dalam. Ook 206/19, hoewel in een over het hof van het z.g. Madjapait handelende passage, heeft berpindjoeng koening, de koet. en niet de jav. bet. $-27 \mathrm{~N}$ wel abus. barang iplv. barang-barangkan; de laatste vorm is mij niet bekend, doch natuurlijk volkomen syn. met mal. sembarangkan (barang-barang $=$ sembarang). $-32 \mathrm{~N}$ berdaoeng iplv. berdaboeng $-34 \mathrm{~N}$ eerste dan ontbr. - 35 doedi, 199/30 id., koet. = mal. kemoedian, bdj. sd. id., atj. doedòe. Volgens Aanh. vdW., waar de bet. minder juist met dibelakang wordt weergegeven, is het ook ser.

\section{4}

$3 \mathrm{~N}$ als Tnt. 1 - $4 \mathrm{~N}$ دبق iplv. rabak - N itoe na petoeng $8 \mathrm{~N}$ ditamainjalah iplv. ditambahinjalah $-8 \mathrm{~N}$ دبث iplv. rabak - 11 $\mathrm{N}$ jang na tangannja - 13 ringkoe, mijn helpers onbekend, blijkbaar een, misschien speciaal Basaps, muziekinstrument. Vgl. KV 40, waar ringkoe bajan naast soeling genoemd wordt als een muziekinstrument van Poeteri Karang Melenoe. - N تمفو i iplv. tapoeng, lees tompong, koet. een soort van bamboezen blaasinstrument, vgl. br. ser. toempong, bamboe voor water (ook boeg. mak. tompong, aan het uiteind gespleten bamboe, in boenga ritompong en tompong-tompong?). - $14 \mathrm{~N}$ als Tnt. 2; telali ${ }^{\text {, }}$ koet. een soort van bamboezen blaasinstrument, vgl. oud-boeg. toelali, Barese toejali, fluit, Murut (Br. N.-Borneo) toelali, neusfluit (Owen Rutter, The Pagans of North Borneo, p. 111), Ajoeh (W.-Borneo) telalé, fluit (afgebeeld bij Schadee, Bijdrage tot de kennis van de ethnographie der Westerafdeeling van Borneo, Int. Arch. Ethn. 9, 1896, plaat III, fig. 4), ng. talali, een bamboesoort. $-17 \mathrm{~N}$

فماهماr dus als Tnt. 4 - $19 \mathrm{~N}$ iplv. letoep, pass. id., ook - $20 \mathrm{~N}$ désanja - 21 melimpas, koet. voorbijgaan, passeren, br. ser. id., 23, 199/9 melimpasi, id. -22 poeloe, koet. $\pm=$ mal. toelah, bijvoorbeeld door gebruik te maken van wat vorstelijk prerogatief is, vaak gebezigd in verwensingen: poeloe toelah boesoeng! Tussen selamat en petjah mist men het woordje demi, zoals dat in een dergelijke vervloeking thuishoort, vgl. 190/8/11. Het wegvallen hiervan wordt verklaard door het feit, dat $\mathrm{N}$ met petjah een nieuwe blad- 
zijde begint. $-23 \mathrm{~N}$ als Tnt. $7-\mathrm{N}$ malimpasi iplv. melimpasnja itoe (vgl. Tnt. 8) - $25 \mathrm{~N}$ als Tnt.9-26 Mangkocradja? - Kiham, t.r. Kéham, naam van een in het tussen Moeara Moentai en Kotabangoen gelegen meer Oeis uitwaterende rivier. $-27 \mathrm{~N}$ als Tnt. 10, doch de $p$ door oorspronkelijke $s$ heengeschreven, vandaar B's lezing. Het gelijktijdig op verschillende plaatsen openspringen van de petongs vindt in de natuur zijn analogie in het bij verschillende bamboesoorten optredende verschijnsel van simultane of massa-bloei (vgl. De Tropische Natuur 28, 1939, bl. 119-121).

\section{5}

$2 \mathrm{~N}$ als Tnt. $1-3 \mathrm{~N}$ enja iplv. $i a-\mathrm{N}$ als Tnt. $2-4 \mathrm{~N}$ als Tnt. 3 - $6 \mathrm{~N}$ als Tnt. $5-7 \mathrm{~N}$ iplv. pengasan, zie 173/17 - $9 \mathrm{~N}$ als Tnt. 6, behalve dat abus. tweemaal dengan wordt geschreven. $10 \mathrm{~N}$ kekanak - $15 \mathrm{~N} \mathrm{ja} \mathrm{iplv.} \mathrm{jang,} \mathrm{lees} \mathrm{-nja.} \mathrm{-} 16$ belah, koet. breken, stuk gaan, gebroken $=$ mal. petjah. $-\mathrm{N}$ als Tnt. 8. $-20 \mathrm{~N}$ abus.

ن splv. diapoen, men leze iapoen. $-21 \mathrm{~N}$ als Tnt. $10-25 \mathrm{~N}$ terlaloelah $-26 \mathrm{~N}$ laloelah iplv. eerste laloe $-27 \mathrm{~N}$ tertidoer iplv. eerste tidoer $-28 \mathrm{~N}$ als Tnt. $12-29 \mathrm{~N}$ als Tnt. 13.

\section{6}

$8 \mathrm{~N}$ als Tnt. 8 - 9 sendjata besar, 26 id., een fraaie uitdrukking voor bedil, kanon, wat in parallelle passages staat, bv. 121/7. - $14 \mathrm{~N}$

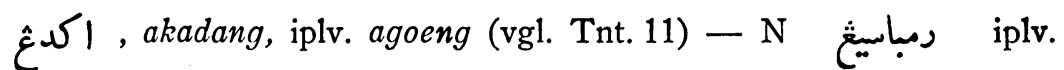
rembes ing $-16 \mathrm{~N}$ als Tnt. $13-17 \mathrm{~N}$ bertjeritalah $-\mathrm{N}$ als Tnt. 14 $-18 \mathrm{~N}$ als Tnt. $15-20 \mathrm{~N}$ didalam $-21 \mathrm{~N}$ dan ontbr. $-\mathrm{N}$ als Tnt. $16-22 \mathrm{~N}$ ia na berganti-gantilah $-28 \mathrm{~N}$ als Tnt. $18-31 \mathrm{~N}$ dan ontbr. - 33 mengadang, 177/1, 178/13 v., kon men te Tenggarong niet verklaren. Blijkens parallelle plaatsen als $132 / 20$ v., 139/5 moet het dansen betekenen, en wel bepaaldelijk bekandjar. Het is bp. ngadang, „dansen”. Vgl. boes. ngarang, wat blijkens Nieuwenhuis' beschrijving in Quer durch Borneo II, 140, hetzelfde is als koet. bekandjar, en het mengarang (er staat mengazang) gantar der Benoea's, beschreven door Witkamp in TAG 1925, bl.21, dat dus gantar-dansen betekent. Vgl. ook Tarakan ngarang, Tidoeng, Tinggalan ngalang, „dansen”. 


\section{9}

4 maroean, vermoedelijk spelt B evenals N ماروز , t.r. meroen.$5 \mathrm{~N}$ als Tnt. $2-6 \mathrm{~N}$ bini na adapoen (vgl. Tnt. 3) $-\mathrm{N}$ didalam -7 $\mathrm{N}$ balonja iplv. bocloenja $-10 \mathrm{~N}$ didalam $-12 \mathrm{~N}$ als Tnt. 5 en 6 - $\mathrm{N}$ mangkin iplv. makin - $14 \mathrm{~N}$ eerste itoe ontbr. - $15 \mathrm{~N}$ maka vóór Meragoei - $16 \mathrm{~N}$ didalam - $18 \mathrm{~N}$ dan ontbr. - $\mathrm{N}$ didalam $19 \mathrm{~N}$ tandanja $-21 \mathrm{~N}$ als Tnt. $11-22 \mathrm{~N}$ als Tnt. $12-24 \mathrm{~N}$ als Tnt. $15-\mathrm{N}$ mangkin iplv. makin $-26 \mathrm{~N}$ als Tnt. $17-27 \mathrm{~N}$ als

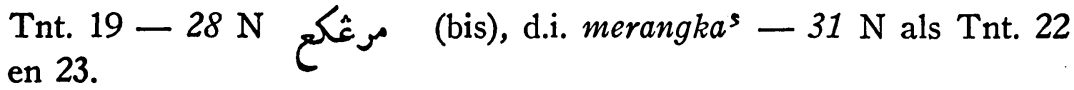

\section{8}

$2 \mathrm{~N}$ als Tnt. $1-7 \mathrm{~N}$ masing $-8 \mathrm{~N}$ didjawatnja iplv. didjawat (vgl. Tnt. 3) $-9 \mathrm{~N}$ didalam -- $17 \mathrm{~N}$ mengira2kan iplv. mengirau-, iraukan - $19 \mathrm{~N}$ didalam - $21 \mathrm{~N}$ تابؤ iplv. Taboek - N بُؤو iplv.

Banaoe. De spelling wijst op de uitspraak Banō, ligging onbekend. $23 \mathrm{~N}$ als Tnt. $12-26 \mathrm{~N}$ orangpoen $-27 \mathrm{~N}$ als Tnt. $14-28 \mathrm{~N}$ dan tussen bini en memboenoeh $-29 \mathrm{~N}$ als Tnt. 15 en $16-30 \mathrm{~N}$ als Tnt. 17.

\section{9}

$2 \mathrm{~N}$ als Tnt. $1-\mathrm{N}$ keradjat iplv. kerdjat $-3 \mathrm{~N}$ ditidjaskan (-kan is door een oorspronkelijk kepada heengeschreven, vgl. Tnt.2) $-6 \mathrm{~N}$ als Tnt. 5-8 Adji itoepoen dibawa oranglah toeroen keair besar; de ceremonie menoeroenkan ketepian is bedoeld, zie aant. bij 120/2. -

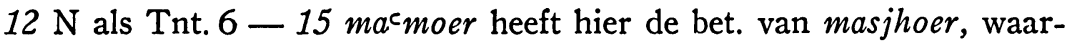
mee het blijkbaar is verward; 184/2, 185/24 heeft het de gewone bet. $-16 \mathrm{~N}$ asing iplv. lain (vgl. Tnt. 7) $-20 \mathrm{~N}$ sekaliannja $-23 \mathrm{~N}$ diatoerkanlah $-25 \mathrm{~N}$ als Tnt. $11-26 \mathrm{~N}$ als Tnt. $12-29$ v. berhanjoet, 34, 194/11 en pass. id., letterlijk zich laten afdrijven, de rivier afzakken, het tegenovergestelde van moedik, $=$ mal. mengilir, milir. In hedendaags koet. is het samengetrokken tot banjoet (uit besanjoet), dat evenals het bdj. balaboeh, dat eigenlijk ook de rivier afzakken is, in het algemeen naar benedenstrooms gelegen gebied gaan betekent, al was het te voet of per auto. - 30 toeboeh, 34, 180/4 id., koet. als mal. en als hulptelwoord voor personen gebruikt. Vgl. het analoge 
gebruik van ng. biti, lichaam. - Bij karena of anders ergens in de volgende regel begint een stuk directe rede, lopend tot het eind van de eerste regel der volgende bladzij. $-31 \mathrm{~N}$ als Tnt. $13-32 \mathrm{~N}$ keloear - $33 \mathrm{~N}$ baik (vgl. Tnt. 14).

\section{0}

$1 \mathrm{~N}$ kekoempai (vgl. Tnt. 1) -2 tiada berkaroean naast 3 tiada karoean, vgl. mal. $t$. berketahoean naast $t$. ketahoean. $-7 \mathrm{~N}$ mangkin - $11 \mathrm{~N}$ moestaciblah - $26 \mathrm{~N}$ als Tnt. $7-29 \mathrm{~N}$ abus. berikan - N poelih iplv. boléh, zo ook 31 (vgl. Bnt. 9!), 181/4/31, $182 / 14$ id., koet. ergens ingaan, passen (kledingstukken e.d.). Overigens zou in deze regel boléh ook wel mogelijk zijn, vgl. 182/5/7. - $31 \mathrm{~N}$ poelih badjoekoe iplv. boléh badjoe - $32 \mathrm{~N}$ itoe ontbr.

\section{1}

3 beroeloenkan, 30 id., lett. tot slaaf hebben (maken), verbloemde term voor huwen, waarbij hier het meisje als slavin (in de letterlijke zin komt oeloen slechts eenmaal in de Sal. voor, $141 / 22 \mathrm{v}$.; als nederig pron. pers. 1 e pers. $=$ patik $: 161 / 5$, of oeloen andika, 162/13/16) van den man wordt gedacht, evenals in 181/5/32 dipe(r)oeloen. Wanneer Poentjan Karna in 234/2 minta pasoeloen kepada Dérva. Adji Ratoe Poeteri stelt hij zichzelf als de oeloen van zijn a.s. echtgenote voor, terwijl hij in 232/17 (minta dipasoeloen) vraagt om 's vorsten dienaar te mogen zijn. Het gebruik komt overeen met dat van mal. berhambakan en diperhamba. $-4 \mathrm{~N}$ poclih iplv. boléh (vgl. noot 1) $-5 \mathrm{~N}$ abus. pasoeloennja iplv. dipe(r)oeloennja $-7 \mathrm{~N}$ baik $-10 \mathrm{~N}$ maka ontbr. $-\mathrm{N}$ als Tnt. $2-12 \mathrm{~N}$ als Tnt. $3-18 \mathrm{~N}$ laloelah $-20 \mathrm{~N}$ als Tnt. 8 - $23 \mathrm{~N}$ mara ${ }^{5}-27 \mathrm{~N}$ itoe na berkais-kaisan - $29 \mathrm{~N}$ ki na hai (vgl: Tnt. 9) - $31 \mathrm{~N}$ soeroehlah $-\mathrm{N}$ poelih iplv. boléh (vgl. Bnt. 11).

\section{2}

$2 \mathrm{~N}$ als Tnt. 1, doch itoe in r. 2 ontbr. -5 lain, 197/18/20, koet. = mal. boekan; bdj. snd. lamp. (lajin) id. $-6 \mathrm{~N}$ اكغ أغ , akadang iplv. kedang $-\mathrm{N}$ als Tnt. $3-7 \mathrm{~N}$ badjoenja $-12 \mathrm{~N}$ als Tnt. 4 en 5 , eenvoudiger gezegd: eerste itoe seperti ontbr. $-13 \mathrm{~N}$ itoe iplv. itoelah 
- $\mathrm{N}$ als Tnt. $6-14 \mathrm{~N}$ poelihlah iplv. boléhlah $-15 \mathrm{~N}$ baik $-\mathrm{N}$ kembali $-17 \mathrm{~N}$ als Tnt. $7-\mathrm{N}$ tjintjinnja $-22 \mathrm{~N}$ maka ontbr. $\mathrm{N} k i$ iplv. kiai -26 berkata-katanja, lees berkata, katanja - $\mathrm{N} k i$ na hai (vgl. Tnt. 9) $-32 \mathrm{~N}$ als Tnt. $10-33 \mathrm{~N}$ sekaliannja.

\section{3}

$1 \mathrm{~N}$ hai vóór mamakoe (vgl. Tnt. 1) $-3 \mathrm{~N}$ baik $-8 \mathrm{~N}$ kenaikannja $-16 \mathrm{~N}$ als Tnt. 2 en 3-20 karangan setandjoeng, een tandjoeng vol karangan, koet. grint (volgens vdW is de uitspraak kerangan, doch ik hoorde te Tenggarong karangan), bdj. ng. id. Tandjoeng, oever in de binnenbocht van een rivier, die als het ware een kaap vormt, is algemeen mal., ofschoon in de meeste woordenboeken onvoldoende verklaard. Wilk. geeft deze bet. onder telok en rantau, niet sv. (ter aanvulling van Bespr. 306, noot). - rinding, koet. een wilde petai-soort, waarschijnlijk Parkia biglobosa (P. Roxburghii), welke periodiek zijn blaren verliest. - 21 gerak, lees garak, koet. afvallen van blaren, bloemen e.d. Afgevallen rinding-blaadjes, eigenlijk de blaadjes der bladvinnen, zijn inderdaad een zeer goed beeld voor ontelbaarheid. $22 \mathrm{~N}$ als Tnt. 5 (er is toevallig een punt boven de $z$ terechtgekomen in het hs., hetgeen B's lezing verklaart). $-23 \mathrm{~N}$ itoe tussen meletoep en itoelah -26 djenang, 203/5 vv. id., regeringsperiode, leven, geslacht van een vorstelijk persoon, jav. djeneng. Vgl. djenang-berdjenang in $\mathrm{KV} 1$, dat syn. is met toeroen-temoeroen. Voor mendjenangkan zie aant. bij 120/6. - 28 aanhalingstekens sluiten achter dinegeri Koetai iplv. in r. $32-29 \mathrm{~N}$ als Tnt. $9-30$ sebab soemahannja beloem habis dibajar; vgl. K 55, waar de verlangde bruidschat - in één rij opgestelde oude potten van Koetai Lama tot de monding der Bengalon (zie ook $165 / 27)$ - op één rantau na wordt afbetaald. - $32 \mathrm{~N}$ soesahlah $-\mathrm{N}$ als Tnt. 10 .

\section{4}

$7 \mathrm{~N}$ berpoeteralah $-\mathrm{N}$ als Tnt. $1-9 \mathrm{~N}$ als Tnt. $2-11 \mathrm{~N}$ sampailah - N als Tnt. 4; bilang boelannja, $\mathrm{N}$ steeds zo $(17 / 24 / 31$, $185 / 5 / 12$ ) behalve 184/6: bilangan $b$. Het schijnt een staande uitdrukking te zijn. In andere mal. teksten vindt men, voorzover ik weet, steeds bilangan b. $-12 \mathrm{~N}$ berpoeteralah $-\mathrm{N}$ als Tnt. $5-\mathrm{N}$ dinamaï $13 \mathrm{~N}$ als Tnt. 7 - Maharadja Soerawangsa wordt hier de tweede zoon genoemd, evenals in KV 56 ( $M$. Soeradizeangsa), doch overal elders, 
waar de gebroeders van Maharadja Soeltan worden opgesomd in de Sal. komt hij op de vierde plaats (187 v., 195, 203, 224, 227 v., 230, 232). - $15 \mathrm{~N}$ besar-besar - $16 \mathrm{~N}$ hamil $-17 \mathrm{~N}$ als Tnt. 11 $\mathrm{N}$ berpoeteralah ia iplv. berpoetera-20-21 N anak - segala ontbr. (vgl. Tnt. 15) $-22 \mathrm{~N}$ als Tnt. $16-24 \mathrm{~N}$ als Tnt. $17-\mathrm{N}$ boelannja ontbr. $-25 \mathrm{~N}$ als Tnt. $18-\mathrm{N}$ laki iplv. laki-laki $-26 \mathrm{~N}$ als Tnt. $20-$ $\mathrm{N}$ dipoengoet iplv. dipoengoetkan $-28 \mathrm{~N}$ besar ${ }^{2}-29 \mathrm{~N}$ poeteri itoepoen iplv. poeteripoen.

\section{5}

$4 \mathrm{~N}$ als Tnt. $1-6 \mathrm{~N}$ als Tnt. $2-10 \mathrm{~N}$ als Tnt. $4-\mathrm{N}$ itoe ontbr. - $12 \mathrm{~N}$ ia na sampailah $-13 \mathrm{~N}$ als Tnt. 5 - 16 Dérwa Poeteri; Tromp, aant. 42, zegt van haar: „Van Dewa Poetěri, de zuster van Maharadja Soeltan, komen volgens mondelinge overlevering de dewa's. Men zegt dat zij in een droom had gezien dat zij tot de "Sangiang" (goden) behoorde en dat zij ook later tot hen is teruggekeerd, zeven dewa's als haar vertegenwoordigsters achterlatende. Van dit zevental stammen de latere dewa's af, die tot den huidigen dag in eere zijn gebleven." Vergelijk hierbij Sal. 226/30 v.: zij wordt gevolgd door 40 déwa's; 229/12-27 : zij treedt op als dézwa en verdwijnt; 230/17-31: zij deelt haar broers in de droom mede, dat zij tot haar oorsprong is teruggekeerd. $-18 \mathrm{~N}$ jang na radja-radja $-19 \mathrm{~N}$ als Tnt. $7-23 \mathrm{~N}$ datang iplv. berdatangan (vgl. Tnt. 8) $-\mathrm{N}$ dan ontbr. -25 kembali, $235 / 15$ en pass. id., koet. verscheiden van een vorst (zie vdW), praegnant voor de bekende uitdrukkingen kembali kerahmatoellah of kembali dari pada negeri jang fana kenegeri jang baka (vgl. 247/14, 249/27). $29 \mathrm{~N}$ als Tnt. $9-29$ vv. tjandi poera, 186/5 id., een samenstelling, mij van elders onbekend, syn. van tjandi (168/1). - $32 \mathrm{~N}$ als Tnt. $10-$ $33 \mathrm{~N}$ dinaikkanlah - 34 Voor de opdracht waarvan hier sprake is zie $167 / 33-168 / 2$.

\section{6}

1-3 Zie aant. bij $167 / 34-4 \mathrm{~N}$ als Tnt. $2-6 \mathrm{~N}$ didalam - beberata; koet. berata, rouw, boeg. mak. id. (vgl. jav. brata, zie 118/19), ook: rouwen (beberata van de tekst is niet meer in zwang). Vgl. r. 18 memboeka berata, de rouw afleggen. Tromp bl. 10 leest hiervoor memboeang beratap en geeft in aant. 36 een beschrijving van een volgens hem dusgenaamde ceremonie bij de Toendjoengs (Tring-Dajaks). Bij 
het neerschrijven van het tweede woord heeft zijn kennis van het mal. hem blijkbaar parten gespeeld. Het „luide weeklagen", waarover hij spreekt, vinden wij in het toeroen tangis van r. 10 weer. $-9 \mathrm{~N}$ keradjat iplv. kerdjat $-10 \mathrm{~N}$ itoe na madjatnja $-\mathrm{N}$ laloelah $-12 \mathrm{~N}$ itoe na toedjoeh $-13 \mathrm{~N}$ Semboejoetan iplv. Samboenjoetan - $15 \mathrm{~N}$ als Tnt. $9-16 \mathrm{~N}$ bersama ${ }^{2}-20$ mendirikan radja, 195/23, 202/9 id., vgl. 240/25, een letterlijke weergave van mendj(oem)enangkan, zie aant. bij 120/6. $-21 \mathrm{~N}$ als Tnt. $10-22 \mathrm{~N}$ als Tnt. $11-25 \mathrm{~N}$ jang na adindanja $-26 \mathrm{~N}$ itoe na orang $-28 \mathrm{~N}$ sakti $-30 \mathrm{~N}$ als Tnt. 12 - $31 \mathrm{~N}$ penglihat iplv. penglihatan - $33 \mathrm{~N}$ als Tnt. 13 - De toevoeging tiada bij Tnt. 14 is onjuist. Maharadja Indrawangsa geeft als bezwaar tegen zijn verheffing niet, dat „zijn uiterlik minder gunstig was" (Mees, bl. 84), doch juist, dat hij zo schoon van uiterlijk was. Het gaat hier immers om goede eigenschappen, waarvan de vier oudste broeders er ieder slechts één bezitten, terwijl Maharadja Soeltan ze alle in zich verenigt. Met roesak sekalian anak bini orang wil niet gezegd zijn, dat zijn uiterlijk ,een kwade invloed zou uitoefenen op alle geboorten in het land" (Mees ib.), doch wel, dat het met de zedelijkheid der dames zou spaak lopen, als hij met zijn mooie gezicht de scepter zou zwaaien. Vgl. Oend. B. N. fasal 14, waarin wordt vermeld welke handelingen alzo onder het halsmisdrijf van meroesakkan anak bini orang worden begrepen. Anak bini (of isteri) orang betekent ,andermans vrouwvolk", en niet, ,de dochter van een anders vrouw" (Mees' vertaling bij fasal 9) en ook niet precies ,een anders vrouw of dochter” (id. bij fasal 14). - N roesak iplv. roesaklah.

\section{7}

$5 \mathrm{~N}$ als Tnt. $1-6 \mathrm{~N}$ lemahlah $-10 \mathrm{~N}$ als Tnt. 4 - keras benar soeara; ik vermoed, dat soeara een latere toevoeging is, en dat er oorspronkelijk van Maharadja Soerawangsa alleen werd gezegd, dat hij zo keras, d.i. gestreng was, zoals wij in 188/10 en 15 lezen. De kinderachtige opmerking over de geduchte uitwerking van zijn luide stem in r. $12 \mathrm{v}$. is dan evenmin oorspronkelijk. - 11 orang is vreemd; men zou verwachten orang jang baik of se(m)barang (hiervan zou soeara wel een verschrijving kunnen zijn!) orang. - 13 kesoemangatan, koet. hevig ontsteld, vgl. mal. hilang semangat. - $14 \mathrm{~N}$ mendjadi -17 sebelas negeri, $186 / 19$ en $188 / 19$ id., de vier van $179 / 12$ vv. plus de zeven van $186 / 12$ vv. - 21 kroengoe, 208/30 keroengoe, t.r. kerongo, koet. dom (vgl. Tromp aant. 37) $-28 \mathrm{~N}$ als Tnt. $6-29$ mertabat (t.r. martabat) 
wordt hier en in het vervolg gebruikt in de bet. van bijzondere eigenschap, uitnemende eigenschap. $-30 \mathrm{~N}$ als Tnt. $8-33 \mathrm{~N}$ sekalian na kakanda $-34 \mathrm{~N}$ als Tnt. 9.

\section{8}

$3 \mathrm{~N}$ als Tnt. $1-7 \mathrm{~N}$ boléh ontbr. $-8 \mathrm{~N}$ cadilnja $-9 \mathrm{~N}$ als Tnt. 4 - $10 \mathrm{~N}$ als Tnt. 5 - keras, zie aant. bij $187 / 10-14 \mathrm{~N}$ dan na ${ }^{c}$ adil $20 \mathrm{~N}$ itoe na eerste kakanda $-\mathrm{N}$ als Tnt. $7-\mathrm{N}$ sertaïlah iplv. serta itoelah; dit figuurlijk gebruik van menjertaï ook 251/35 menjertaï kehendak radjanja. - 21 pakaian radja, 208/35, 209/6 v. id., de speciale eigenschappen, die den vorst behoren te sieren, of de gedragslijn, die hij behoort te volgen. Zie ook 209/11: hendaklah radja itoe memakai atas lima perkara, enz. Vgl. Oend. B. N. fasal 17: Adapoen pakaian orang besar djangan meninggalkan isjarat dengan moesjawarat dan moepakat. Vgl. ook Moestiko 'Adat CAlam Minangkabau, bl. 22 : anam sipat nan ka dipakai, itoe pakaian dès pangocloe. Over dit gebruik van pakai(an) zie ook Van Ophuijsen, Opmerkingen over de Oendangoendang Djambi (Bijdr. 46, 1896), bl. 200, die pakaian met ,gewoonten en gebruiken" weergeeft. $-23 \mathrm{~N}$ baik $-29-189 / 5$ is bijna gelijkluidend aan 235/23-30. - $30 \mathrm{~N}$ seboet iplv. diseboet, lees terseboet (vgl. 189/5) - $32 \mathrm{~N}$ radja na mendjadi (vgl. Tnt. 8).

\section{9}

$1 \mathrm{~N}$ Koetai tiada radja mendjadi menteri tiada menteri mendjadi radja dan (vgl. Tnt. 1-3) - $3 \mathrm{~N}$ haroe-hara djoealah iplv. haroeharalah (vgl. Tnt. 4) - 4 tahoen tiada djadi, d.i. koet. taoen mandis djadi, de rijstoogst (is) mislukt; vgl. Oend. B. N., fasal 52, bl. 329/8 tahoenpoen tiada mendjadi, waarvoor beide door mij geraadpleegde Tenggarongse hss. tahoen tiada djadi hebben. Vgl. min. pataoenan, rijstoogst, bdj. lapas tahoen, mislukt van de oogst, sd. salah taoen, id. enz. -6 tussen inilah en Maharadja Sakti vermoed ik een lacune. - 7 v. N gagas iplv. gaga, 27 id.; gaga $a^{s}$, kraai, staat hier klaarblijkelijk als beeld voor zwart (vgl. 229/6). Wédjén gagas is dus een mooie uitdrukking voor wédjén itam, vgl. 124/4. - $9 \mathrm{~N}$ als Tnt. 6-12 kampoeng kawal, koet. kampongbewoners, kamponggenoten, vgl. bdj. kawal $=$ mal. kawan, vriend. - $\mathrm{N}$ dengan na kawalnja $-19 \mathrm{~N}$ als Tnt. $9-20$ kehabishabisan soempah, de ,definitiefste" eed, de allerzwaarste eed. - meloeroeskan, moet volgens mijn helpers meloroskan gelezen worden, wat een 
taki-syn. van menoeroenkan zou zijn; men ontkende, dat het, naar ik vermoedde, een schrijffout voor meloeroehkan was. Loros betekent in de dagelijkse taal overigens invallen, ineenstorten, zoals bv. een oud huis; in KV 15 wordt het van een trap gezegd. Meloroskan daoen kajoe hidoep, menaikkan daoen kajoe mati is een spreekwoordelijke uitdrukking om de geweldige kracht van de eed aan te duiden. $-21 \mathrm{~N}$ als Tnt. 10, met dan na Darmazwangsa $-25 \mathrm{~N}$ als Tnt. $12-26$ Het verhaal van het bezoek aan de berg Sangiang Angkat-angkatan (250/6 zonder Sangiang) stelt ons voor diverse moeilijkheden. In de eerste plaats is reeds beslist, wie radja zal worden, zodat de krachtproef - wij vernemen hier voor het eerst, dat deze is ingesteld door Batara Agoeng Padoeka Nira - niet verricht behoeft te worden, wat dan ook niet geschiedt. Waarom wordt de tocht dan gemaakt? Misschien om de goedkeuring van de steen, die tegen de voorschriften in niet bij de koningskeuze werd geraadpleegd, te verkrijgen? De zin, die met karena (r. 28) begint, bevat wel een motivering, doch hetgeen gemotiveerd wordt, is niet uitgedrukt. Wanneer wij aannemen, dat hiermee stilzwijgend het bezoek der broeders is bedoeld, blijven wij toch een zegen.bede of een eed missen. Tenslotte is ook vreemd de mededeling (190/2), dat Maharadja Sakti na zijn woorden w e e r o $m$ tot de sangiang ging en o o k da a r een eed zwoer. Vermoedelijk is ergens een belangrijke lacune, waarschijnlijk tussen kedaton en soedah in 190/2. - 27 N gagas $-\mathrm{N}$ berkata - 28 tempat? $-30 \mathrm{~N}$ beraboet iplv. berboeat, lees bereboet $-\mathrm{N}$ als Tnt. $13-31 \mathrm{~N}$ dibawaslah iplv. dibawa oléh (vgl. Tnt. 14).

\section{0}

2 eerste $i a$, lees $j a n g$ - kedaton, hierna aanhalingstekens sluiten; zie verder aant. bij 189/26. $-3 \mathrm{~N}$ als Tnt. $1-5$ ditimboenkannja, lees ditamboenkannja volgens koet. spraakgebruik, evenals tamboen(an) in 9 en 11. Koet. namboen, ophopen, = mal. menimboen, welk laatste woord in het koet. een andere bet. heeft, zie 128/26. N heeft in de bovenaangehaalde plaatsen geen vocaalaanduiding in de eerste lettergreep, terwijl het hs. in alle afleidingen van timboen op één na steeds de $i$-vocaal aangeeft. $-7 \mathrm{~N}$ als Tnt. $4-8 \mathrm{~N}$ djandjinja -9 roetoek, 11 id., lees rotok, koet. vuilnis, droog vuil $=$ mal. sampah $-\mathrm{N}$ tjilaka - $\mathrm{N}$ als Tnt. $7-10$ menetepi, lees menetapi, koet. nakomen, evenals mod. mal., van jav. netepi. $-\mathrm{N}$ iplv. $t i d a^{s}$; het is bij $N$ een 
gewone schrijfwijze voor tadi, wat hier evenmin als $t i d a^{5}$ en het volgende kakanda past. Ik houd deze woorden voor een verbastering van tanda akan. Deze conjectuur vindt gedeeltelijk steun in de lezing van I: tanda kakanda. $-11 \mathrm{~N}$ als Tnt. $8-13 \mathrm{~N}$ als Tnt. $9-22 \mathrm{~N}$ pertama 2 $-24 \mathrm{~N}$ itoelah iplv. inilah $-26 \mathrm{~N}$ als Tnt. 11 en $12-27 \mathrm{~N}$ als Tnt. $14-29 \mathrm{~N}$ als Tnt. 15 , lees $-n j a$ iplv. $i a$ ? $-\mathrm{N}$ ia na disalahkan, lees $-n j a$ ? - $30 \mathrm{~N}$ toea ontbr. abus. - $31 \mathrm{~N}$ dikatakannja iplv. dikatakan (bis) $-\mathrm{N}$ als Tnt. 16 en 17.

\section{1}

$2 \mathrm{~N}$ akan na adapoen -3 pakai, vgl. mal. makan pakai, kleding en voeding, bdj. id. $-7 \mathrm{~N}$ baik, abus. gevolgd door een losse alif, iplv. baiklah. - 7-14 Deze passage lijkt een verkorte herhaling van $188 / 22$ vv., die niet geheel op haar plaats is. $-13 \mathrm{~N}$ als Tnt. 2 $14 \mathrm{~N}$ bertagoeh2anlah berdjandji iplv. bertegoeh-tegoehan djandji (vgl. Tnt. 3) - $16 \mathrm{~N}$ als Tnt. $4-17$ v. berpangkoean, lees berpangkon $20 \mathrm{~N}$ sebenarnjalah -22 tatakerama, 26, 194/8 en pass. id., omgangsvormen (jav.); 205/18 totokromo volgens de jav. uitspraak. $-23 \mathrm{~N}$ als Tnt. 8-24 N spelt gewoonlijk Madjapaït - 25 sidik tanpa ngoetjap ( $\mathrm{N}$ tan pengoetjap), 197/15 id., een verbastering van jav. sidik pengoetjap (vgl. KBW sv. siddhi 2e). Mogelijk door den schrijver opgevat als "effect sorteren zonder zelfs maar te spreken". Tan staat misschien voor een oorspronkelijk tang, vgl. 144/22 teroes (tan) peningal. - 33 menggelar, lett. een titel verlenen (vgl. 128/14) doch hier meer bepaald inhuldigen, tot de met een bepaalde titel, i.c. die van ratoe, aangeduide rang verheffen. Hierbij $226 / 18 / 24 \mathrm{v}$. penggelaran, het formulier, waarbij de verlening van een titel wordt bekend gemaakt, inhuldigingsformulier. De titels, die de Sultan van Koetai eens per jaar verleent aan enkele verdienstelijke ambtenaren en beambten, worden op plechtige wijze in de kraton afgekondigd door voorlezing van een in niet geheel zuiver Javaans gestelde penggelaran. Een letterlijk afschrift van zo'n stuk uit de tijd van Sultan Soelaiman moge hier volgen. De woordenkeus is sedert niet veranderd, behalve dat men thans ,ing Martadipoera” zegt. De pericopen, waarachter het cijfer 3 staat worden bij de voorlezing driemaal herhaald. De Maleise dagtekening wordt natuurlijk niet voorgelezen. 


\section{فونيك هيثكغ فاثنديك كثجغ سـينوهون شي سـلطان \\ محمّد سليمان العادل الحليفة المؤمنين ايثمرتافود/انجانثكن \\ منتريكداتون روثكو مس ويرانكراس/سـفاب تن ثاراني

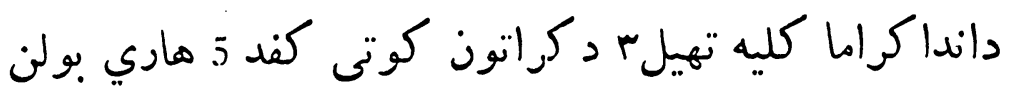 \\ صفر تاهون 1298}

Het gebruik van deze formule wordt in Oend. B. N. fasal 73, laatste alinea voorgeschreven. $-34 \mathrm{~N}$ als Tnt. 11 .

\section{2}

2 masing 2 lah $-5 \mathrm{~N}$ jang na tjaranja - $6 \mathrm{~N}$ abus. gendang na soeara - $\mathrm{N}$ gong iplv. egoeng $-8 \mathrm{~N}$ maka na gamelan - $14 \mathrm{~N}$ bintolo iplv. bantolo $-15 \mathrm{~N}$ als Tnt. 4, doch tiga tussen emas en soesoen. Verder leze men daar: bertengkang iplv. bertangkang, gadjah angoeling iplv. keangoeling ( $\mathrm{N} k a$ angoeling), berdjamang iplv. berdjemang. $16 \mathrm{~N}$ als Tnt. $5-17$ mengkoer, lees moengkoer $-\mathrm{N}$ beroerab $^{2}-$ $19 \mathrm{~N}$ tinatah na berkeris (vgl. Tnt. 7) - 22 lanti, t.r. lanté -23 diépok. $\mathrm{N}$ id., doch lees met $\mathrm{K}$ dan épok, evenals $131 / 20$. - $\mathrm{N}$ als Tnt. 9 $\mathrm{N}$ pepangkon iplv. pengangkoean - 25 Gantar, t.r. Gentar - 28 tanggal, lees toenggal - N léngganglah iplv. berléngganglah -29 bergentarlah, lees met 131/26 bergoentoerlah (spelling N aldaar بر كنتورل ) $-30 \mathrm{~N}$ dan ontbr. $-31 \mathrm{~N}$ als Tnt. 12.

\section{3}

$3 \mathrm{~N}$ abus. دي فاردj iplv. diperidan - $6 \mathrm{~N}$ maka na (h)amparan 8 moesjawaratkan ( $\mathrm{N}$ mesaoeratkan), 10, 11 moesjawarat ( $\mathrm{N}$ mesaoerat); de gewone bet. van het woord past hier niet, het schijnt plechtig afkondigen te betekenen. Bij de beschrijving van de inhuldigings- 
ceremonie van Maharadja Soeltan als vorst van Koetai Karta Negara staat in plaats van dit woord membatja(lah) penggelaran. (226/17). Misschien mag gedacht worden aan jav. moesazuarataké, „omtrent iets iemand raadplegen om zijn oordeel te vernemen"; men zou het woord dan vrij kunnen weergeven met ,(den vorst aan de aanwezigen) voorstellen". - 10 v. N بردربله. iplv. berdirilah, 11 id., wel als berderablah uit te spreken, doch بردريله 12 , berderailah, wat zeker de goede lezing is. Men bedenke, dat de menigte bij de sembah in een dergelijk geval een langgerekt poen laat horen, voor welk geluid berderap niet het geëigende woord is. Overigens wordt $226 / 18 / 20 \mathrm{vv}$. in een parallelle passage door $\mathrm{N}$ ook steeds berderablah gespeld. $-12 \mathrm{~N}$ berderailah sembah iplv. berdirilah (vgl. Tnt. 4) - 13 Gantar, t.r. Gentar - 14 terinja, N spelt تاريث - $18 \mathrm{~N}$ maka na kedoeanja - $19 \mathrm{~N}$ bertahtalah; bertachta diatas keradjaannja, 24, 197/11 en pass. id. : keradjaan in de zin van tachta keradjaan vindt men ook veelvuldig in de verdere mal. litteratuur, doch in de woordenboeken wordt van deze bet. geen gewag gemaakt. Vgl. bv. Sedj. Mel. 80/16 baginda tocroenlah dari atas keradjaannja, van de troon afdalen, als beeld voor het afstand doen van het koningschap; Hik. Radja 2 Pasai, 50/20 id. De concrete bet. van keradjaan komt mooi uit in Sal. 250/32 v.: maka dibawa oranglah masoek kepedalaman didoedoekkan oranglah diatas keradjaan. $-21 \mathrm{~N}$ poenggawanja. $-22 \mathrm{~N}$ sekaliannja $-25 \mathrm{~N}$ dagang 2 an $-\mathrm{N}$ macmoer - $27 \mathrm{~N}$ besar ${ }^{2}-28 \mathrm{~N}$ sekaliannja - N als Tnt. 7 - $32 \mathrm{~N}$ iplv. kembali; het gehele woord had natuurlijk geschrapt moeten zijn. $34 \mathrm{~N}$ als Tnt. $9-\mathrm{N}$ pamitlah $-35 \mathrm{~N}$ als Tnt. 10.

\section{4}

$1 \mathrm{~N}$ boebarlah $-2 \mathrm{~N}$ masing 2 lah -3 id. $-6 \mathrm{~N}$ als Tnt. $2-8 \mathrm{~N}$ beradja ${ }^{2}$ iplv. beradja-radjaan; de laatste vorm zou ongeveer ,,koninkje spelen" betekenen; 249/18 vertoont B dezelfde fout. $-10 \mathrm{~N}$ berkata $-14 \mathrm{~N}$ als Tnt. $3-18 \mathrm{~N}$ als Tnt. $4-\mathrm{N}$ banjaknja iplv. baiknja$\mathrm{N}$ itoe ontbr. $-19 \mathrm{~N}$ als Tnt. 5 (de herhaling is natuurlijk een vergissing). $-21 \mathrm{~N}$ als Tnt. $7-22 \mathrm{~N}$ maka na itoe $-\mathrm{N}$ Saktipoen $-23 \mathrm{~N}$ maka na datang (vgl. Tnt. 8) $-25 \mathrm{~N}$ laloelah iplv. laloe $-27 \mathrm{~N}$ maka na itoe $-30 \mathrm{~N}$ bermain $^{2}$. 


\section{5}

$2 \mathrm{~N}$ als Tnt. 1 - dirapatinja, ging langszij liggen van (de vorm niet in de woordenboeken) $-3 \mathrm{~N}$ itoe na Indramoelia $-4 \mathrm{~N}$ sekoetika ia iplv. seketikanja $-\mathrm{N}$ als Tnt. $2-5 \mathrm{~N}$ als Tnt. $3-6 \mathrm{~N}$ als Tnt. $4-$ $7 \mathrm{~N}$ menjoeroeh na Sakti (vgl. Tnt. 5) - 9 awak alapi, vgl. 231/23 mengalapi, moet afhalen, inhalen betekenen. Het is echter te Tenggarong niet bekend. I $\mathrm{k}$ vind geen vrijheid om met $\mathrm{T}$ en $\mathrm{K}$ alaki te lezen; vgl. jav. $-10 \mathrm{~N}$ als Tnt. $8-17 \mathrm{~N}$ als Tnt. $9-20 \mathrm{~N}$ maka ontbr. $22 \mathrm{~N}$ memandérkan $-27 \mathrm{~N}$ baik $-30 \mathrm{~N}$ moestaciblah -31 perbakalannja, t.r. perbekalannja - $\mathrm{N}$ radja $-33 \mathrm{~N}$ asoekoe iplv. sikoe 34 bebahan, lees babahan - amaténi, jav. doden.

\section{6}

$1 \mathrm{~N}$ (drio) iplv. darik; pantjo drio, t.r. pontjo-drio, jav. pantjadria, de vijf zintuigen. - lilma (N لِ sل) ), lees lima of eventueel lilima (jav.) - dariwangan-wangan ( دريواثن ), lees drio anganangan (of angen-angen, jav.). De verklaring van pontjo-drio midden in de tekst is echt wajangstijl, zie de inleiding. $-\mathrm{N}$ als Tnt. 2; de spelling der eerste drie woorden is ائ إيو إئ - anak sipendjoendjoeng dan si pendjoeal kangkoeng, beeld voor iemand van zeer lage afkomst, ,zoon van een putjesschepper”. $-2 \mathrm{~N}$ als Tnt. 3-3 N akadang iplv. kedang - $5 \mathrm{~N}$ bajoe iplv. banjak. - pengibaran leide men af van jav. iber, en niet van mal. kibar, zie ook r. 10; angin pelajangan bajoe pengibaran betekent dus ,een zweefwind, een vliegbries”.

- N باؤمبس iplv. berhoembas; de tegenwoordige koet. uitspraak is echter beroembas, van een grondwoord roembas, wild en hoog uitzwaaien bij het schommelen; beroembas vindt men ook in $\mathrm{KV} 44$. $6 \mathrm{~N}$ als Tnt. 5 - djoeroe, koet. hoek $=$ mal. pendjoeroe $-7 \mathrm{~N}$ als Tnt. 6 - keritjoet, 8 id., lees kerétjot, koet. kraken, knersen. $-9 \mathrm{vv.}$ De namen der gewesten van het hemelruim, die in het volgende worden opgesomd, kan ik helaas voor het grootste deel niet thuis brengen. Misschien zou men bij belians of déwa's een nadere verklaring kunnen verkrijgen van deze hemelvoorstellingen, waarin blijkbaar zowel Javaanse als Dajakse elementen zijn te bespeuren. De tekst maakt op verschillende plaatsen de indruk corrupt te zijn. - $\mathrm{N}$ didjawang art 
iplv. didjoeang hari; volgens mijn helpers zou dit ditengah oedara betekenen. Vermoedelijk werd gedacht aan diawang(-awang), waarvan djawang inderdaad een verbastering zou kunnen zijn. - 10 ketarketaran, trillend? bij jav. keter? - Mardjoe Kentang, 29 id., lees mardjò-gantang, jav. mardja-g., een verbastering van madya-g., 't midden van het luchtruim (vgl. KBW sv. madya 2e). $-11 \mathrm{~N}$ maka na "Kentang" - 13 hing, naast r. 27 ing, jav. (h)ing = mal. di; vgl. 230/15 masoek ing keraton! - $15 \mathrm{~N}$ ketinggalanlah - 16 Kambarkambar, 28 id.? Men zou hier ke-ambara-ambara kunnen lezen, gedachtig aan jav. ambara = awang, maar dat past niet bij r. 28. -17 djaoen, 19, 24 id.; dit is vermoedelijk tndj. djaoetn, wolk. -18 ia slaat op Maharadja Soeltan en M. Sakti. - Pali Bagindjau, N

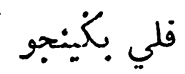

25 id.? - N bertjampoeh iplv. bertjampoe, 26, 197/4 id., waarschijnlijk bij jav. tjampoeh, zich verenigen. $-20 \mathrm{~N}$ spelt soerolaja w. w. soerolojo - wiloe-wiloe, 21 id., lees wélò-wélò, jav. wéla-wéla, zeer duidelijk te zien; het schijnt hier als de naam van een bepaalde hemel te zijn opgevat. Het tweede soeralaja (soerolojo) kan gemist worden, tenzij hier iets is uitgevallen. - tertjengang staat hier ongeveer als opp. van het in de volgende regel voorkomende toendoek, dus \pm als tengadah. Vermoedelijk is het van het mal. afwijkend gebruik van tjengang, dat men ook enige malen in $\mathrm{KV}$ aantreft, koet., en gelijk aan dat van bdj. tjangang, dat kijken, soms ook opzien (bv. van zijn werk om naar iets te kijken) betekent, implicerend enige duur van de handeling en enige afstand van het bekekene, doch geen verbazing. Vgl. KV 32 kanakkanak itoepoen tjengang keatas, het kind zag op naar boven, 48 maka orang toeha itoepoen tertjengang kepada itoe petong, maka terlihatlah $i a$, de oude keek (op) naar de bamboe, en toen ontwaarde hij ...., 62 ditjenganginja, keek hij er naar (bdj. ditjanganginja) $-21 \mathrm{~N}$ soerolojo iplv. Soeralaja - 22 melengah, drukfout voor meléngah, als $241 / 37$, koet. $=$ mal. menoléh, omzien, min. id. $-23 \mathrm{~N}$ als Tnt. $11-$ 25 poesar toeloeng? vgl. poesar angin in r. 19. $-26 \mathrm{~N}$ terada iplv. eerste tiada - N bertjampoeh - $27 \mathrm{~N}$ iplv. Latar, reduplicatie of schrijffout? vgl. 13 hing latar diatas angin. - $28 \mathrm{~N}$ maka na tweede djoea - 29 Mardjoe Kentang, lees mardjo-gantang - N iplv. Pemagian Hari, uitspr. en bet. van het eerste woord, dat ook 197/2 voorkomt ( $p$. goenoeng) onbekend. Misschien pemanggian bij jav. panggih? - 30 méga malang, jav. 't zwerk, de wolken. 


\section{7}

1 mandi-mandi, ceremonieel baden; waarom dat hier geschiedt? $\mathrm{N}$ als Tnt. 1 - $2 \mathrm{~N}$ فمغن iplv. pemangkin, zie 196/29 - pahat dalam? - $4 \mathrm{~N}$ bertjampoeh - $12 \mathrm{~N}$ poenggawanja - 13 Berma Widjaja, zoals de vorst van het z.g. Madjapait hier steeds genoemd wordt, is een verbastering van jav. Bra Widjaja; tegenwoordig noemt men hem te Tenggarong Broh Widjòjò. - $15 \mathrm{~N}$ spelt sidik tan pengoetjap taroes tan peningal iplv. sidik - peninggal. $-20 \mathrm{v}$. koekedjapi, de vorm niet in de woordenboeken, vgl. jav. ngedèpi; cf. ook KV 61 dikidjapinja. -21 achter hilang of itoe moet iets zijn uitgevallen in de trant van akan tetapi djika tédja manoesia. $-22 \mathrm{~N}$ als Tnt. 6 $23 \mathrm{~N}$ laloelah; de plotselinge overgang van de woorden van den jav. vorst op de wederwaardigheden van de koet. vorsten doet vermoeden, dat er in het voorafgaande iets is uitgevallen, hetzij na negeri, hetzij na het laatste kalinja van r. 22. $-27 \mathrm{~N} \hat{\varepsilon}^{1}$ iplv. sekarang; geen van beide woorden geeft veel zin, tenzij karang hier syn. van paséban is (vgl. jav., ,erf”). Misschien echter heeft er oorspronkelijk (dipaséban) agoeng gestaan, en is k.rang een verbastering van het laatste woord. $29 \mathrm{~N}$ als Tnt. 7 - $31 \mathrm{~N}$ kekanak - $\mathrm{N}$ di(belakang Mahara) mana ${ }^{2}$ iplv. dibelakang Maharadja; het tussen haakjes geplaatste is echter doorgehaald. $D i$ had ook moeten vervallen. Een en ander verklaart de lezingen van $\mathrm{B}$ en $\mathrm{T}$. Men leze dus berlarianlah, mana-mana jang enz.

\section{8}

$4 \mathrm{~N}$ jang iplv. hiang - menjoeroeng, t.r. menjorong, 13, 226/28 id., koet. omhoog schuiven (intr.), rijzen (van grond). Vgl. ng. manjoeroeng, groeien, aangroeien, aanslibben (vgl. Hardeland sv. soeroeng en Mallinckrodt, Adatrecht van Borneo I, 373), vermoedelijk ontleend aan het bdj., en zie Klinkert's opgave sv. tanah: ,tanah noeroeng en $t$. njoeroeng, in het Palemb. aangeslibde grond?" - $6 \mathrm{~N}$ setinggil iplv. sitinggil, 203/20 en pass. id., in overeenstemming met koet. uitspraak. In Tromp's tijd verstond men er onder „een gele achtkantige geheel open kiosk van circa 2 meter middellijn, waarvan de vloer ongeveer 2 voet boven den grond is" (Tromp aant. 159, bl. 100). Thans zou men er het podium van de geheel in Europese stijl uitgevoerde Sultanstroon in de kraton onder verstaan. - binatorono, 226/27 id., t.r. binoto-rono, jav. binata-rana, geplaveid. $-9 \mathrm{~N}$ als Tnt. $1-16 \mathrm{~N}$ als Tnt. $4-$ 
kemit, schijnt hier niet bepaald nachtwacht te betekenen, doch wacht in het algemeen. In 't jav. betekent kemit ook dienst als nachtwacht verrichten, zoals hier 227/20 menteri jang kemit. Zie nog 239/5 berkemit, de wacht houden en 210/12 mengemit, bewaken, waarvoor $\mathrm{K}$ de waarschijnlijk betere lezing mengemiti heeft (vgl. jav.). Het woord is te Tenggarong thans nog alleen bekend in oeang kemit, hetzelfde als oeang tiga tali, het door de herendienstplichtigen jaarlijks aan het kamponghoofd zelve verschuldigde berlrag. - $18 \mathrm{~N}$ poen iplv. itoepoen $21 \mathrm{~N}$ als Tnt. 6 - santana dalam, 22 v., 199/12 en pass. id., jav. $s$. dalem, familieleden van den vorst van mindere rang. $-\mathrm{N}$ pergilah $23 \mathrm{~N}$ diliatnjalah iplv. dilihatinja - $26 \mathrm{~N}$ spelt مأسود iplv. maksoed; in r. 28 en 199/2 vinden wij معسود 231/35 , Deze spellingen wijzen op de uitspraak $m a^{5}$ soet, die inderdaad in Koetai gehoord wordt; vgl. padoeras sa 169/3. - $29 \mathrm{~N}$ maras -31 id. - Na dahoeloe aanhalingstekens sluiten. - $34 \mathrm{~N}$ mengatoer - sampéan, 199/2/8 en pass. id., jav. hoog pron. pers. 2e pers. Misschien is het destijds ook te Koetai in gebruik geweest, evenals nog in bdj. het geval is (sampian, pian); vgl. 238/33, waar het naast andika wordt gebezigd. Het is thans echter niet meer bekend. $-35 \mathrm{~N}$ als Tnt. 9 .

\section{9}

$1 \mathrm{~N}$ negeri na dari (vgl. Tnt. 1) $-2 \mathrm{~N}$ mara ${ }^{5}-5 \mathrm{~N}$ als Tnt. $3-$ $8 \mathrm{~N}$ setinggil iplv. setinggi $-\mathrm{N}$ als Tnt. $4-9 \mathrm{~N}$ als Tnt. $5-11 \mathrm{~N}$ pergilah $-13 \mathrm{~N}$ als Tnt. $6-16 \mathrm{~N}$ als Tnt. $7-17 \mathrm{~N}$ als Tnt. 8$21 \mathrm{~N}$ abus. panggil $-23 \mathrm{~N}$ als Tnt. $9-24 \mathrm{~N}$ als Tnt. $10-25 \mathrm{~N}$ melaloeï iplv. laloe (vgl. Tnt. 11) - $\mathrm{N}$ dipadang iplv. dipandang; dipadang orang banjak betekent in koet. en bdj. temidden der menigte, mal. ditengah-tengah orang banjak; vgl. bdj. dipadang babinian, midden tussen de vrouwen (nl. als enige man). $-30 \mathrm{~N}$ doedi iplv. doedoek; , ,ada poen lagi doedi" is het antwoord van de sentana dalam op 's vorsten vraag ,ada dimana satria itoe?" $-\mathrm{N}$ als Tnt. 12 - 31 priaji, 200/34, $201 / 1 / 16 / 19$ id. lees paranjaï, zie 206/17. - N pengadas iplv. pengada (vgl. Bnt. 13!); 34, 200/35 pengadak, blijkbaar het jav. pangadeg, een stel kleren. $-32 \mathrm{~N}$ als Tnt. $14-33 \mathrm{~N}$ als Tnt. 15.

200

$2 \mathrm{~N}$ laloelah $-5 \mathrm{~N}$ namanja $-6 \mathrm{~N}$ als Tnt. $1-11$ seri menganti, $222 / 2$ id., jav. „naam van de noorderbuitenpoort van het binnenste van 
de kraton". Vg1. 206/26, 210/28/30 gedong seri menganti, naam van het verblijf, dat Maharadja Soeltan als logeergelegenheid wordt aangewezen, waarschijnlijk een der 2 pendopo's, die de poort, naar Pigeaud mij meedeelt, flankeren. Elders $(205 / 31,214 / 4 / 6)$ wordt hetzelfde verblijf gedong mahajanti genoemd. - 12 anoem, 15, 18, 22 id., t.r. anom (jav.) - N kendaga l. iplv. Gondagalanti, lees gendaga lanté, evenals $15,18,22 .-13 \mathrm{~N}$ als Tnt. $2-20$ mara $^{\text {s }}$ na masoek (vgl. Tnt. 3) $30 \mathrm{~N}$ als Tnt. 5 - 34 priaji, lees paranjaï.

\section{1}

1 v. mawidji? Pigeaud oppert de mogelijkheid dat dit staat voor jav. midji, in 't bijzonder aangewezen (voor bijzondere dienst). — priaji, lees paranjaï $-2 \mathrm{~N}$ als Tnt. $1-6 \mathrm{~N}$ sawat ( ماواة) iplv. soeatoe, jav. ,algemeene benaming van verschillende batiksels, zooals .... sazvat boma" (GR). $-7 \mathrm{~N}$ t.o. koening na natar - 10 v. kanigara, 13 id., de bekende jav. staatsiemuts. - 11 kenigar, natuurlijk te lezen kanigara, ook al spelt $\mathrm{B}$ het hier op voorbeeld van $\mathrm{N}$ zonder alif aan het eind! - 16 priaji, lees paranjaï (bis) $-17 \mathrm{~N}$ als Tnt. 4 en $5-19$ priaji, lees paranjaï - $22 \mathrm{~N}$ als Tnt. $7-24 \mathrm{~N}$ laloelah $-25 \mathrm{~N}$ als Tnt. 8 $26 \mathrm{~N}$ maka na makan (vgl. Tnt. 9) -27 vv. Deze enigszins verbasterde welkomstgroet uit de wajang ziet er in Arabisch schrift bij $\mathrm{N}$ aldus uit:

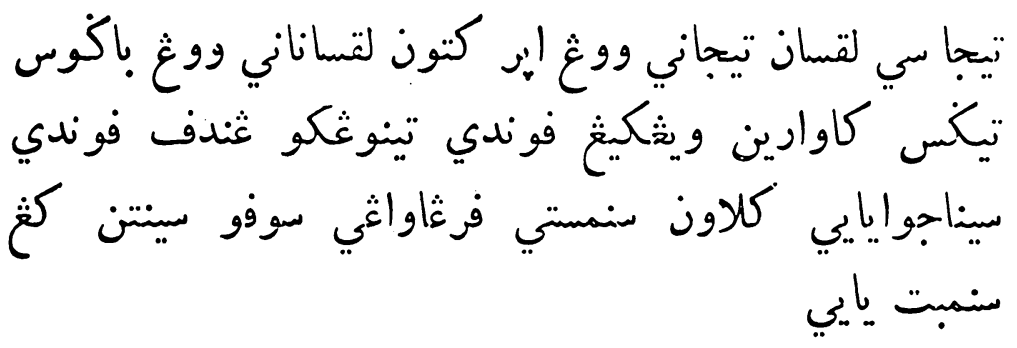

De niet geheel vaste formule in de Soerakartase padalangan luidt o.a., naar Pigeaud mij meedeelt: „Tédja-tédja soelaksana, tédjané wong anjar katon, ing boeri ngendi pinangka, ing ngarep ngendi kang sinedya, tigas kawoerjan, sapa sinambat ing wawangi", waarnaast ook voorkomt: „Tédja-tédja soelaksana, tédjané wong asaé anjar katon, déné leksanané nembé kawoerjan, rèhning katambetan, ing wingking poendi pinangka, ngadjeng poendi sinedya". 
$5 \mathrm{~N}$ als Tnt. $1-7 \mathrm{~N}$ namanja $-8 \mathrm{~N}$ maras -10 Maharadja Sakti! in r. 5 wordt het gezegde aan M. Soeltan toegeschreven. Tussen radja en Atoer moet iets uitgevallen zijn. - $11 \mathrm{~N}$ kepada na dan20 kendia, koet. straks, $=$ mal. kelak, nanti, bdj. käna, kéna $-\mathrm{N}$ als Tnt. $4-21 \mathrm{~N}$ als Tnt. $5-22$ melain, 28 id., koet. apart, alleen voor zich; melaini, afwijkend (vgl. Tnt. 9) $-23 \mathrm{~N}$ als Tnt. $7-24 \mathrm{~N}$ ia ontbr. - $25 \mathrm{~N}$ Saktipoen - $26 \mathrm{~N}$ dan ontbr. $-27 \mathrm{~N}$ als Tnt. 8 $34 \mathrm{~N}$ batjoba2han, deftige uitspraak van betjoba an, vgl. aant. bij $154 / 6-35 \mathrm{~N}$ als Tnt. 10.

\section{3}

$2 \mathrm{~N}$ als Tnt. $2-\mathrm{N}$ djangan $د$ iplv. djanganlah; iplv. ada leze men met Tnt. 3 adik, of liever adi, zoals $\mathrm{N}$ in de volgende regels (4-8) en 204/16/18 spelt, jav. adi. $-3 \mathrm{~N}$ اكدع, akadang iplv. kedang $5 \mathrm{~N}$ als Tnt. $5-7$ boejoet, 259/4 id., koet. bdj. achterkleinkind (jav.) $-8 \mathrm{~N}$ djangan $-15 \mathrm{~N}$ itoe ontbr. $-18 \mathrm{~N}$ als Tnt. 8 en $9-19 \mathrm{~N}$

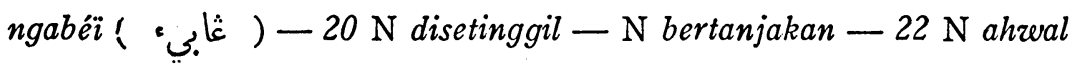
$-\mathrm{N}$ sekaliannja $-29 \mathrm{~N}$ terseboetlah -30 ia na singgahlah.

\section{4}

$2 \mathrm{~N}$ akoeawa iplv. akoe koeawa; vermoedelijk is koeawa zonder akoe bedoeld. - $3 \mathrm{~N}$ dan na berdjoedi - $\mathrm{N}$ terada na menjaboeng (vgl. Tnt. 2) - $5 \mathrm{~N}$ ka-Merekaman - $8 \mathrm{v} . \mathrm{N}$ (اكوثَث (saagoenging) iplv. seagoeng jang, 223/3 v. id. Beter is 205/9 سأكوغيخ , te lezen sagoenging, litt. jav. alle. - $11 \mathrm{v}$. adalah ia is in $\mathrm{N}$ tussen Soeltan en maka gekrabbeld, waar het ook beter op zijn plaats is. $-12 \mathrm{~N}$ bersabdalah - 15 habislah sekalian orang jang itoe, blijkbaar zijn enkele woorden uitgevallen; men kan deze bv. als volgt aanvullen habislah poelang sekalian orang jang mengadap itoe. $-16 \mathrm{~N}$ adi iplv. adik, evenzo in het vervolg. $-17 \mathrm{~N}$ memintas -20 adjar betekent hier minder „leren”, dan wel „raden, adviseren”. Iplv. pengadjar in de volgende regel zou men misschien pengadjaran verwachten, doch vgl. min. pangadja, dat ook raadgeving, advies beduidt. $-26 \mathrm{~N}$ als Tnt. $7-$ 
$\mathrm{N}$ tananti2, bandjariserend iplv. te(r)nanti-nanti-29 N فارسن iplv. perasaan, naar een bestaande uitspraak *perasan?

\section{5}

$1 \mathrm{~N}$ als Tnt. $1-\mathrm{N}$ radja iplv. radja-radja -2 bermoeliakan, in mal. gewoonlijk memoeliakan, mempermoelia(kan). $-8 \mathrm{~N}$ als Tnt. 2 $9 \mathrm{~N}$ sagoenging iplv. seagoeng jang (bis) $-15 \mathrm{~N}$ als Tnt. $3-18$ tetiti, lees met TK r. 21 titi, jav. nauwgezet (mogelijk is de geredupliceerde vorm ook in gebruik geweest). - N سورتي iplv. soeraté, lees soerti, 21 id., jav. voorzorg. Titi soerti is een vaste jav. samenstelling: nauwgezet en met voorzorg. - doego prajogo ( $\mathrm{N}$ spelt nauwkeurig vocali-

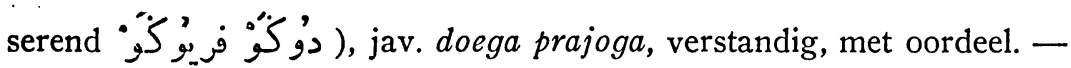
tindak-tandoek, jav. handelwijze - 20 mengadak (N مثدأ ), 22, 240/12 id., de juiste bet. kon men mij niet opgeven. In een pekenanfragment, opgetekend door Pangéran Tjokro, komt echter ratoe menga$d a k$ en poetri mengadak meermalen voor als parallelle uitdrukking van adji kesoema (vorstelijk persoon van zuivere afkomst). In 240/11 v. staat anak radja-radja keloearan tegenover radja (lees anak radja) jang mengadas. Een en ander wekt het vermoeden dat het woord "regerend" betekent (jav. ngadeg). $-21 \mathrm{~N}$ als Tnt. $7-\mathrm{N}$ soerti iplv. soeraté 23 tiada boléh didoeaï, kan niet met een ander gedeeld worden, vgl. 209/20 mendoeaï keradjaan; cf. jav. ngloroni. - $24 \mathrm{~N}$ didalam $26 \mathrm{~N}$ Widjajapoen - $27 \mathrm{~N}$ berangkatlah $-28 \mathrm{Na}$ Maharadja moet Sakti ingevoegd worden (vgl. Tnt. 8) - $30 \mathrm{~N}$ als Tnt. $9-\mathrm{N}$ Widjaja - N itoe iplv. ia - $31 \mathrm{~N}$ مهينت iplv. mahaniti; de uitspraak is blijkens 214/4/6, mahajanti. Met gedoeng mahajanti schijnt hetzelfde bedoeld te zijn als met gedoeng seri menganti, zie 200/11. - $33 \mathrm{~N}$ als Tnt. $10-34 \mathrm{~N}$ orang.

\section{6}

$2 \mathrm{~N}$ als Tnt. $2-\mathrm{N}$ terpasanglah $-3 \mathrm{~N}$ als Tnt. $3-5$ léko, hier en overal elders te lezen likoe - $6 \mathrm{~N}$ menjoegoeh, iplv. menjoegoehi (vgl. Tnt. 4); ook in 't jav. komt njoegoeh naast het gebruikelijkere njoegoehi voor. $-7 \mathrm{~N}$ als Tnt. $5-8 \mathrm{~N}$ spelt فاوون , vandaar „paoean”, lees echter pawon, jav. keuken. - $9 \mathrm{~N}$ masaklah iplv. ma- 
soeklah - satai, volgens koet. (jav.) uitspraak saté. De geredupliceerde vorm, die $\mathrm{N}$ slechts éénmaal te zien geeft (r. 12), sesaté, vindt men o.a. in bal. en sas. - $10 \mathrm{~N}$ كر iplv. goréng, lees garang, jav. droog bakken, roosteren. Met de hier genoemde saté garang asam vgl. oclam garang asem bij Mayer, Jav. Volksleven bl. 214. - panggang goeling? vgl. bal. een aan 't spit gebraden beest, varken, eend (KBW) ? bébék, door $\mathrm{N}$ met cain aan het eind gespeld, vandaar T's lezing bibing!

- tjoetjoch? - 11 déndéng kepoek ( $\mathrm{N}$ ), lees met $\mathrm{K} d$. gepoek, jav., zie GR s.v. dèndèng - déndéng anggi, lees $d$. agé, jav. een bepaald soort van dèndèng, beschreven bij Mayer, Jav. Volksleven, bl. 215 en in KBW. - $\mathrm{N}$ als Tnt. 8 - 12 kambit ( $\mathrm{N}$ )? $\mathrm{N}$ saté iplv. tweede sesatai; saté asam, vgl. KBW sv. asem ,ben. van een sasaté-soort." - N dan na lodéh - 13 N beberapa - 14 N iplv. ganit, lees kenit, jav. een soort van witte rijstbrandewijn. - djenézcar (N جنيوار ) ; de gewone mal. uitspraak is djenéweér, bdj. id.; vgl. echter jav. djenèzer. - arak das, wel hetzelfde als jav. arak adas, zekere sterke drank (adas, venkel). - anas, wel te lezen anis. Volgens KBW betekent dit in bal. en sikka "Chin. arak, geimporteerde arak in 't algemeen". In mak. boeg. is anisi' echter anisette (Matthes: „van ons anijs"; het kan ook van port. anis komen). Vgl. ook KBW sv. enis. In de $\mathrm{Sj}$. Hémop wordt anis meermalen naast anggoer genoemd onder Europese spijzen en dranken (747, 1719, 1806 en elders). $15 \mathrm{~N}$ als Tnt. $9-\mathrm{N}$ abus. تمبو iplv. teboe - $16 \mathrm{~N}$ dan na semangka — N als Tnt. $10-17$ N فرإائي , paranjai iplv. priaji, 25, 207/10 en pass. id., jav. dienares, soort van dienstmeid bij zeer aanzienlijke. Dit moet ook gelezen worden iplv. priaji 200/34, 201/1/16/19, en misschien ook 168/17/24. - $18 \mathrm{~N}$ als Tnt. 11; Adji voor den vorst van Madjapait mag men beschouwen als een slip of the pen. $-19 \mathrm{~N}$ sémbongnja iplv. samboengnja (vgl. Tnt. 12); jav. sèmbong (vgl. Wilk. en GR) of sèmbongan, soort van plooiing van een vrouwenstaatsiekleed (Pigeaud). - N berpindjoeng - dipratjaki, spelling N دي فرجكي, de bedoeling zal wel dipertjiki zijn. - $20 \mathrm{~N}$ angg.r menoer iplv. anggoer manoer, lees anggrék menoer, jav. volgens De Clercq 3107 
dezelfde orchidee als anggrèk boelan. Vgl. Babad Pati (hs. B.G. 452, bl. 329) tjoendoeké anggrèk menoer (kleding van Rara Mendoet). 21 geloeng bokor sinalangan; geloeng bokor is als bepaalde wijze van haar opmaken op Java bekend; sinalangan? - 23 méga berangkat is blijkbaar de technische benaming voor een bepaalde figuur gevormd door de pilis. - $\mathrm{N}$ angalar iplv. ngalar; angalar koembang sari, vgl. jav. anglar kombang, als k.-vleugels. - $\mathrm{N}$ koemilab iplv. goemilap pepelik, jav. zeker oorsieraad, mal. pelik-pelik. $-25 \mathrm{~N}$ paranjai iplv. priaji - 26 linggih, of schoon in 't jav. ngoko, is het hier kennelijk als een hoog woord voor zitten bedoeld. Ook in 't bdj. is het basa dalam bij doedoek. - N ديادأ كدوغ vermoedelijk eerst „diadap oléh ......" willen zetten. - $31 \mathrm{~N}$ seorangnja iplv. seorang orangnja $-33 \mathrm{~N}$ als Tnt. 14.

\section{7}

$1 \mathrm{~N}$ orang $-2 \mathrm{~N}$ als Tnt. $1-\mathrm{N}$ برلارد. iplv. berlaril-larihan - 5 padoeka matoer dan padoeka likoe, 7, 211/30, 215/34 v., 216/24. Ook 213/12-15, waar de volgorde van 's vorsten gemalinnen wordt aangegeven, wordt $p$. likoe uitdrukkelijk de laagste genoemd. Gewoonlijk komt overigens in de mal. litteratuur in opsommingen padoeka matoer na padoeka likoe, zoals in de Sal. bij uitzondering 213/9. Vgl. de aanhalingen in KBW sv. mangoelangi en prameçwari. In de tweede aanhaling onder het laatste woord komt $p$. likoe na $p$. matoer. De volgorde schijnt niet geheel vast te staan. Klinkert noemt beiden de vierde gemalin! - $6 \mathrm{~N}$ poela ontbr. - 9 na ratoe mist men de mededeling, dat het thans de beurt der bijvrouwen was om te eten. $-\mathrm{N} n j a i$ iplv. jaji; njaï isteri is onmogelijk; waarschijnlijk is tussen beide woorden een stuk uitgevallen. Immers ontbreekt de mededeling, dat de personen, van wie hier sprake is, eten. $-10 \mathrm{v}$. $\mathrm{N}$ kepedas iplv. kepada, 13, 222/4/17 id., jav. kepedak, (groep van) ondergeschikte vorstendienaren. - 10-13 N overal paranjaï iplv. priaji-13 $\mathrm{N}$ kepedas lanang iplv. kepada lanang-lanang $-\mathrm{N}$ als Tnt. 3, doch kepedas lanang iplv. kepada alanang - 14 soeroegani, lees sorogeni, jav. sara-geni, naam van een met geweren bewapend pradjoerit-corps van den Soesoehoenan. - kadjinaman, t.r. kadjineman, jav. wakers. - 15 niaga, jav. gamelanspeler - $\mathrm{N}$ فنداكن iplv. p.n.dakan; jav. pangendakan, tovermiddel voor het bezweren van wilde dieren (volgens mededeling 
van Pigeaud, vgl. GR). Evenals hieronder (pembelosan, pedjagalan, pesajangan) is de pe-an-vorm door den schrijver der Sal. blijkbaar opgevat als te betekenen de bedrijver van de handeling, die met het grondwoord in verband staat, mogelijk onder bdj. invloed. De oorspronkelijke betekenis zal wel zijn de plaats, de wijk, waar deze mensen wonen. Pedjagalan is als naam van wijken in verschillende steden van Java bekend; Pasajangan is de naam van een wijk in Martapoera bij Bandjermasin. Pigeaud vermoedt, dat met pengendakan de jagers zijn bedoeld. -16 toenggok, lees toenggoek, jav. verplichte wacht. $-\mathrm{N}$ sinoman iplv. sinoem; jav. tot diensten verplichte jongelingengroep 17 piskal setabel, bien étonnés de se trouver ensemble! In de Compagniestijd werden djaksa's inlandse fiscaals genoemd. Jav. setabel is ned. konstabel. De bet. van het engelse constable zou beter passen, maar hoe komt men er aan? $\mathrm{N}$ spelt het eerste woord zonder enige klinkeraanduiding. $-\mathrm{N}$ pembaloe $e^{5}$ in iplv. pembaloean, waarschijnlijk te lezen pembelokan, jav. pambelokan, blok, doch hier zijn bedoeld degenen, wier werk het is mensen in het blok te zetten, dus cipiers (vgl. aant. bij r. 15). - pedjagalan, jav. eigenlijk slagerij, slachterswijk, hier: de slagers (vgl. aant. bij r. 15). - 20 sedoengan? - magarsari, jav. magersari, bijwoner op het erf van een aanzienlijke $-21 m(e)$ ranggi, jav. krisschedenmaker $-\mathrm{N}$ dan na besi-22 pesajangan, bij jav. sajang, (rood)koperslager (vgl. aant. bij r. 15) penggandingan, lees penggendingan, bij jav. gending, gamelanmaker (vgl. aant. bij r. 15). - djanti, jav. indigo; met toekang djanti zijn dus de blauwververs bedoeld. - 24 petedan, jav. patedan (k.i.), geschenk aan een mindere; hier schijnen er speciaal de vorstelijke etensresten, mal. ajapan, koet. sisa (vgl. jav.), mee bedoeld te zijn, doch dit is geen jav. spraakgebruik. - $26 \mathrm{~N}$ keloearlah $-\mathrm{N}$ اتيه iplv. téh, wat op de uitspraak etéh wijst. - $27 \mathrm{~N}$ berdjinis - 28 noman, vgl. jav. nomnoman, zeker gerecht (mededeling Pigeaud) $-\mathrm{N}$ als Tnt. 8 - madoe kasirat, ook bij de Bandjarezen bekend soort van gebak, waarschijnlijk het zelfde als jav. madoe sirat. - madoe moengsoe, lees m. mongso, jav. m. mangsa, een soort van gebak. - $29 \mathrm{~N}$ iplv. lelapon? Bedoeld lelepon $=$ jav. kelepon ? In Koetai schijnt men wel lepon te zeggen. I spelt كلالفوj, vgl. bdj. kalalepon of kelelepon $=$ jav. kelepon. - $\mathrm{N}$ als Tnt. 9; sinoekoepan? - 30 ratoe berkoeroeng zou een soort van ondé-ondé zijn (koet). - 33 v. soeaka, $210 / 2$ en pass. id. 
De bet. van dit woord in Koetai geeft Tromp in aant. 43 als volgt weer: „dienen, onderdanig zijn, met alle gevolgen daarvan. Als de Sultan wil uitdrukken, dat een Dajaksch hoofd zich aan hem onderworpen heeft, dan zegt hij, dat het hoofd heeft „soewaka”. Verplichte leveringen, verplichte diensten, worden "soewaka" genoemd; het verschijnen op de "těpoeng-tawar" en andere hoffeesten heet eveneens „soewaka"." Hierbij worde opgemerkt, dat socaka niet als praedicaatswoord optreedt, doch de afleiding bersoeaka, zoals $221 / 17$ v., 25 dienen, 232/2/20, 258/5 zijn onderwerping aanbieden; 232/17 bersoeakakan dirinja, zich onderwerpen.

\section{8}

1 Men mist hier de opsomming welke die vier soorten van soeaka zijn. Op 210/2 wordt wederom over soeaka gesproken, waarvan daar vijf soorten worden opgenoemd. $-6 \mathrm{~N}$ mengaroe iplv. mengharoe, lees meng(h)aramkan als in r. 9? - $9 \mathrm{~N}$ mengaramkan - 12-13 Hier moet een gedeelte zijn uitgevallen, waarin de vorst van Madjapait sprekende wordt ingevoerd. Het is ook niet duidelijk, waar Maharadja Soeltan's woorden eindigen. - $25 \mathrm{~N}$ sama na maka $-27 \mathrm{~N}$ als Tnt. 230 baikkah iplv. baiklah - keroengoe, t.r. kerongo - hali (alleen bij $\mathrm{K})$, koet. syn. van kerongo, onnozel. $-31 \mathrm{~N}$ als Tnt. 3 .

\section{9}

3 kepatian, 5 id., waarschijnlijk te lezen kepatén, betekent blijkens de context levensgevaarlijke momenten (vgl. pati, 129/1) - $4 \mathrm{~N}$ als Tnt. $1-6 \mathrm{~N}$ als Tnt. 2 ( لدري iplv. seri - $7 \mathrm{~N}$ empoenja $-\mathrm{N}$ als Tnt. $3-9 \mathrm{~N}$ als Tnt. 5 (spelling als boven) $10 \mathrm{~N}$ koeda iplv. koedo - $\mathrm{N}$ berani iplv. berani-berani (in $\mathrm{N}$ is koeda jang berani ingevoegd met angka $r$ als verwijzingsteken) - De in regels 6-10 vervatte passage is corrupt. Er schijnen twee dingen door elkaar gehaald te zijn, namelijk de eigenschappen, die een vrouw behoren te sieren, die dan volgens de tekst ook een vorst zouden passen (?) en de bekende rij van vier of vijf zaken, die, indien hij ze in hun volmaaktheid bezit, volgens de jav. zedeleer het geluk eens mans uitmaken, nl. vrouw (wanisa), wapen (tjoeriga), huis (wisma), paard (toerangga) en soms als vijfde vogel (koekila). Hiervan vinden wij in onze tekst er drie terug in r. 7: tjoeriga, koeda, wanita (aldus ook in r. 9 te lezen iplv. koedoenita). De schrijver, die wanita niet begreep, 
vatte het op als syn. van wani, vandaar de „verklaring” koeda jang berani! Van de drie woorden ladri, bakti, sari levert het middelste geen moeilijkheid op. Ladri wordt blijkens de weergave laoetan met jav. djaladri in verband gebracht, doch ook wanneer hier een geestelijke eigenschap is bedoeld, is het naast het abstracte bakti niet erg op zijn plaats. Mogelijk heeft $\mathrm{B}$ het met de lezing ladi aan het rechte eind; als overigens ongebruikelijk grondwoord van jav. ngladèni zou het goed in het verband passen. Sari werd saré gelezen blijkens de weergave met tidoer. Of dit overeenstemt met de oorspronkelijke bedoeling is een andere zaak. - 11 memakai atas, dit riekt naar kitab-maleis. $14 \mathrm{~N}$ als Tnt. 7 - tempat, 17, 24, 210/14, geval (waarin), vermoedelijk een weergave van arab. maudic. $-16 \mathrm{~N}$ als Tnt. 8 en 9; met djalan schijnt hetzelfde bedoeld te zijn als met tempat in r. 14. Vgl. Sj. Hémop 2077, waar eveneens djalan als syn. van mal. tempat, hier in gebruikelijker zin, voorkomt: djoerang telaga djalannja mandi; zie ook ald. 2765 en 2925 . - $21 \mathrm{~N}$ menjalak iplv. menjalangi, $\mathrm{K}$ leest menjalaki. Mijn helpers stelden voor te lezen menjeloki, gedachtig aan de koet. uitdrukking njelosi hati orang, iemands vertrouwen op snode wijze misbruiken (bv. door iemand, wiens gastvrijheid men geniet, te bestelen of diens vrouw te verleiden), = bdj. mantjaloeki hati oerang. $-\mathrm{N}$ memotos iplv. mematoek; memotos lidah radja zou betekenen "melanggar perkataan radja". - 22 menggoelinga tata, dezelfde adatterm vindt men in Oend. B.N. fasal 15, r. 19 als menggoeling tata afgedrukt. De Tenggarongse hss. hebben hier echter evenals het door Van Ronkel besprokene (zie Het Adatwetboek van Koetai, bl.6) magoelinga t.ta. Mees vertaalt het met „de rechtsorde omverwerpen”, maar de juistheid van deze schijnbaar letterlijke vertaling valt nog te bezien. Het is uit de teksten niet op te maken, wat er precies mee is bedoeld. Volgens Tromp aant. 64 bestaat het door hem "měnggoeling tatah" genoemde misdrijf (,mĕnggoeling $=$ rollen, tatah $=$ beitel" geeft hij als verklaring!) uit het zich onttrekken aan een in de kampong opgelegde straf door naar de kraton te vluchten. Iets algemener geformuleerd: ,zich aan een gerechte straf trachten te onttrekken" past deze verklaring ook in de bedoelde passage der Oend. B.N. - 23 malap boemi, bet. onbekend. Misschien „zich wederrechtelijk grond toeëigenen”? $24 \mathrm{~N}$ itoelah jang iplv. itoe (vgl. Tnt. 13); beide woorden moeten echter vervallen evenals tempat radja na boléh (vgl. $17 \mathrm{v}$.) $-\mathrm{N}$ potos iplv. potong, lees dipotos $-25 \mathrm{~N}$ dan ontbr. $-30 \mathrm{~N}$ dan ontbr. $\mathrm{N}$ ia na djikalau - 34 harap di, gewoonlijk leest men harap (a)kan. of harap kepada. 


\section{0}

1 maka terdiri? Vóór of na deze woorden is vermoedelijk weer een lacune. $-6 \mathrm{~N}$ astananja $-\mathrm{N}$ tweede dan ontbr. $-7 \mathrm{~N}$ bentjananja iplv. bintjananja; dit laatste is o.a. bdj. uitspraak. $-21 \mathrm{~N}$ als Tnt. 1, kenjapoeri, 214/5/24 id., jav. „,maagdenverblijf”, hier ruimer, vrouwenverblijf. - $\mathrm{N}$ dikehadapan permaisoe (sic) iplv. kehadapan permaisoeri - 24 berkata, in $\mathrm{N}$ slordig door oorspronkelijk bertanja heengeschreven (vgl. Tnt. 3) $-25 \mathrm{~N}$ itoe ontbr. - $26 \mathrm{~N}$ angat kar.ng iplv. hangat kering $-27 \mathrm{~N}$ paranjaï iplv. priaji $-29 \mathrm{~N}$ paranjaïpoen iplv. priaji - $34 \mathrm{~N}$ bersalinlah - $35 \mathrm{~N}$ paranjai iplv. priaji (bis).

\section{1}

1 v. $\mathrm{N}$ paranjaï iplv. priaji $-2 \mathrm{~N}$ als Tnt. $1-3 \mathrm{~N}$ als Tnt. $2-$ $\mathrm{N}$ berbaring2lah diatas iplv. berbaring-baring (vgl. Tnt. 3) $-4 \mathrm{~N}$ paranjai iplv. priaji -5 mengepoek, $216 / 17$ id., koet. ngepos, i.q. jav. ngepoek, kloppen op. $-7 \mathrm{~N}$ paranjai iplv. priaji - 9 soegara mengambang ( $\mathrm{N}$ m.ng.n.mbang); deze en de andere namen van legersteden der vorstinnen: perang ketitih, babandjaran, karang ng.njap zijn mij niet bekend. - $10 \mathrm{~N}$ als Tnt. 5 - $11 \mathrm{~N}$ babandjaran - $12 \mathrm{~N}$ iplv. Nganjap - 14 senting, N منتئ , misschien *senténg, een kwazie-kramavorm bij jav. sentong? - 16 sekar delima, naam van een gamelan te Djokja, vgl. o.a. R. Soedjono Tirtokoesoemo, De Garebegs in het Sultanaat Jogjakarta, bl. 120. -- 18 segaran, 22 soegaran, hieronder wordt op Java een gegraven vijver verstaan. Met soengai s. kan de waterloop, die deze vijver voedt, bedoeld zijn. $-19 \mathrm{~N}$ als Tnt. 7 $\mathrm{N}$ paranjaï iplv. priaji $-21 \mathrm{~N}$ ia ontbr. $-24 \mathrm{~N}$ naik $-\mathrm{N}$ mandi iplv. mandinja $-25 \mathrm{~N}$ als Tnt. $8-28 \mathrm{~N}$ als Tnt. $9-31 \mathrm{~N}$ paranjäpoen iplv. priajipoen - $32 \mathrm{~N}$ bers.mboer ${ }^{2} a n-B a n d j a r a n$ Sari, is elders in de litteratuur niet de naam v.e. vijver, doch v.e. lusthof, waarin de vijver overigens een voorname plaats inneemt. $-35 \mathrm{~N}$ als Tnt. 10, doch paranjai iplv. priaji itoe.

\section{2}

$3 \mathrm{~N}$ itoe ontbr. $-6 \mathrm{~N}$ paranjaï iplv. priaji $-7 \mathrm{~N}$ memoetik iplv. memetik - 11 oedoe, lees oedo; oedo nagoro, 223/20 (negaro), 224/2 (negara), jav. oeda-negara, takt, gevoel voor wat past in maatschappelijk 
verkeer. $-16-213 / 4$ ontleend aan de Tadjoessalatin, zie de inleiding. -18 sebab negeri radja itoe ontbr. bij $\mathrm{vE} .-19 \mathrm{~N}$ als Tnt. 4 - racjat, $\mathrm{vE}$ hamba Allah $-21 \mathrm{~N} \mathrm{racjat}-24 \mathrm{~N}$ didalam - $28 \mathrm{~N}$ als Tnt. 5 tiada - itoe is eigenlijk overbodig. - 29 hendaklah - toeboehnja staat niet op zijn plaats, en wordt bij $\mathrm{vE}$ van den vorst gezegd. - 35 tiada patoet dilihat, $\mathrm{vE}$ fardoe djoea menoetoep sekalian; na toeboehnja volgen in $\mathrm{vE}$ nog enige nadere aanwijzingen omtrent de bedekking van het lichaam door Mohammedaanse vrouwen. - djika ia dihadap, vE apabila hendaklah ia berkata-kata akan menteri itoepoen dengan boenikan adanja.

\section{3}

$2 \mathrm{~N}$ belakang $-13 \mathrm{~N}$ itoe na matoer $-17 \mathrm{~N}$ als Tnt. $2-20$ padmi, jav. voornaamste echtgenote van lieden van hoge adel. $-23 \mathrm{~N}$ seperti na menoeroet -24 id. $-25 \mathrm{~N}$ hanja $-32 \mathrm{~N}$ paranjai iplv. priaji$33 \mathrm{~N}$ soeroean $-34 \mathrm{~N}$ dalam $-35 \mathrm{~N}$ habislah $-\mathrm{N}$ als Tnt. 7; „béat” wordt bij N يقة gespeld, een schrijffout voor tabīcat.

\section{4}

4 N poelanglah - N مهاينتي, mahajanti, iplv. mahaniti, 6 id. $6 \mathrm{~N}$ Soeltanpoen $-8 \mathrm{~N}$ laloe ontbr. - N mengoras iplv. memboeka $-11 \mathrm{~N}$ paranjaï iplv. orang (vgl. Tnt. 2) $-13 \mathrm{~N}$ itoe ontbr. $-14 \mathrm{~N}$ als Tnt. $3-15 \mathrm{~N}$ silakanlah $-\mathrm{N}$ als Tnt. $4-17 \mathrm{~N}$ laloelah $19 \mathrm{~N}$ als Tnt. $5-\mathrm{N}$ maka iplv. makan $-\mathrm{N}$ diangkat $-21 \mathrm{~N}$ berlarah $^{2} a n$ iplv. berlarih-larihan $-22 \mathrm{~N}$ berapa $-24 \mathrm{~N}$ ratoepoen $32 \mathrm{~N}$ ertinja.

\section{5}

$3 \mathrm{~N}$ jang na eerste dan $-5 \mathrm{~N}$ dan iplv. adapoen; dan artinja - terang in de volgende regel komt bij $\mathrm{N}$ na 11 iboe (vgl. Tnt. 2). $-8 \mathrm{~N}$ pegal lelah iplv. pegallah - 10 kandjeng romo, jav. kangdjeng rama 15 anggadoeh, jav. anggadoeh, in bruikleen hebben, in tijdelijk bezit hebben, lijkt hier minder juist gebruikt. Immers de mens zelf heeft volgens de gangbare opvatting zijn leven als een tijdelijk goed toevertrouwd gekregen (vgl. snd. hiroep gagadoehan, Wdb. Coolsma sv. gadoeh), doch de vorst beschikt over leven en dood, zoals de Woelang Rèh zegt: moerba ing pati kalawan oerip. - pedjah gesang pati oerip 
( $\mathrm{N}$ oerib), jav. dood en leven, in krama en in ngoko! - $18 \mathrm{~N}$ als Tnt. 3 - $19 \mathrm{~N} \mathrm{sebab} \mathrm{-} 20$ anjoekani (N إوكنى ), jav. kr. geven. gonoroso, spelling en bet.? - anggo-anggo, zal wel kleren moeten betekenen, jav. anggon-anggon - mengazini, als dit goed is, betekent het iemand huwen $=$ menikahi, welke laatste vorm alleen door Klinkert is geboekstaafd. De eerste wordt echter ook meermalen in de litteratuur aangetroffen. -24 na berboréh voege men in boréh of beboréh (subst.) - $\mathrm{N}$ beboréh iplv. laatste boréh - $25 \mathrm{~N}$ beboréh iplv. berboréh $26 \mathrm{~N}$ als Tnt. $6-26 \mathrm{vv}$. Deze verbasterde jav. passage is waarschijnlijk ontleend aan een of ander jav. litteratuurwerk, mogelijk een lakon. In tegenstelling tot de welkomstgroet van $201 / 27$ vv. heeft een liefdesverklaring als hier bedoeld geen vaste vorm in de padalangan. Het is dus moeilijk de plaats bevredigend te herstellen. $\mathrm{N}$ leest tot "ongo":

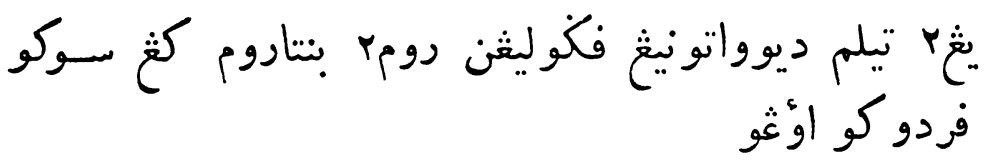

30 mentjakar zou wel zeer grof zijn! Mijn helpers lezen hier mentjakér, koet. met de hand wegduwen, van zich afduwen. $-\mathrm{N}$ menggaroe iplv. menggaroek; koet. nggaroe, krabben; hierbij 252/28 bergaroe, zich krabben en penggaroe, instrument om zich mee te krabben (vgl. Wilk. sv. garu en garok). - $32 \mathrm{~N}$ مثارومץ iplv. menggaroem-garoem, wel te lezen mengeroemroem, malaïsering van jav. ngroengroem, mal. gewoonlijk meroemroem.

\section{6}

$1 \mathrm{~N}$ als Tnt. $1-5 \mathrm{~N}$ kemana $-6 \mathrm{~N}$ baik djoea iplv. baiklah (vgl. Tnt. 2) $7 \mathrm{~N}$ als Tnt. 3-9 N كندوع iplv. gedong, lees géndong - $10 \mathrm{~N}$ dodot iplv. doedoek - 11 emban, 13 id., jav. verzorgster van een kind. $-14 \mathrm{~N}$ als Tnt. $4-15 \mathrm{~N}$ ditoeroenkanlah - 16 goeling, koet. „rolkussen” (jav.); gegoeling van $\mathrm{T}$ en $\mathrm{K}$ is de bdj. vorm. soeraga, zie Klinkert en Wilk. sv. seraga. Te Tenggarong verstaat men thans onder seraga een versiering van een vorstelijk bruidsbed, bestaande uit een rechtopstaande, met gele stof beklede en van boven in twee punten uitlopende plank, waarop in twee verticale rijen een aantal tampoek goeling van gedreven goud zijn gespijkerd. $-\mathrm{N}$ paranjaïpoen iplv. priajipoen - 18 menembang, d.i. jav. nembang, tem- 
bangs zingen. - dandang goela, jav. dandang g., naam van een dichtmaat. — 19 daroewoeh ( $\mathrm{N}$ ols )? Misschien een verbastering van doedoek woeloeh, een andere naam voor de jav. dichtmaat megatroeh? $-21 \mathrm{~N}$ als Tnt. $8-23 \mathrm{~N}$ paranjaï iplv. priaji $-24 \mathrm{~N}$ mahadéwi iplv. likoe - $25 \mathrm{~N}$ likoe iplv. mahadéwi (vgl. Tnt. 10) $26 \mathrm{~N}$ tidoerlah $-\mathrm{N}$ soeri iplv. permaisoeri $-27 \mathrm{~N}$ pagi $2-30 \mathrm{~N}$ als Tnt. $11-\mathrm{N}$ didalam astana -34 isjarat, zie de volgende aant.

\section{$21 \%$}

$1-219 / 34$ ontleend aan de Tadjoessalatin, zie de inleiding. Van de 27 in de editie $\mathrm{vE}$ genoemde sjarats ( شرط ) vindt men hier de eerste 21 terug. Van dit sjarat is het ,isjarat" van de uitgave een verbastering. $\mathrm{N}$ spelt het afwisselend, gedeeltelijk de afkomst nog verradend:

هit de eerste sjarat is een heel stuk weggevallen. $\mathrm{vE}$ leest: sjarat jang pertama: hendaklah menteri itoe berboeat kebaktian akan Hakk soebhānahoe watacălä seperti ia kehendaki kebaktian dari pada segala orang jang dibawah enz. - 4 radjanja, $\mathrm{vE}$ Toehan sarwa sekalian calam - $6 \mathrm{~N}$ noegerahnja iplv. negerinja -7 pada ontbr. bij $\mathrm{vE}-8 \mathrm{~N}$ radja - dihapoeskannja, $\mathrm{vE}$ hapoeskan - $10 \mathrm{~N}$ nocgerah iplv. kerah -12 soeaka orang kepada, $\mathrm{vE}$ sesocatoe pekerdjaan; de lezing van de derde sjarat hier wijkt ook verder sterk van die bij $\mathrm{vE}$ af. $-\mathrm{N}$ als Tnt. $7-14 \mathrm{~N}$ belandja $-\mathrm{N}$ als Tnt. $9-$ $15 \mathrm{~N}$ didalam $-17 \mathrm{~N}$ tiadalah $-18 \mathrm{~N}$ als Tnt. 11, doch lees aldaar: keradjaannja iplv. kerdjaannja - 20 peri kesoekaan, $\mathrm{vE}$ perkakas $21 \mathrm{~N}$ als Tnt. $12-22 \mathrm{v}$. Deze regels zijn corrupt; $\mathrm{vE}$ leest: dan sebagainja semoeanja tertentoe akan radjanja itoe jang memakai dia. De woorden sekalian - bersalahan behoren in de zesde sjarat thuis. 25 peri keradjaannja, $\mathrm{vE}$ pekerdjaan $-26 \mathrm{c}^{\mathrm{adat}} \mathrm{\textrm {vE }}$ hoekoem sjari ${ }^{\mathrm{c} a t}$

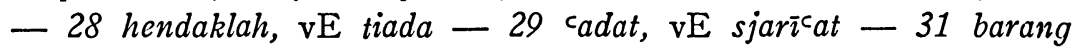
dikehendaki radjanja, $\mathrm{vE}$ barang bitjaranja soepaja ia memboeangkan perinja.

\section{8}

$1 \mathrm{~N}$ mengoeloem ${ }^{2}$ iplv. mengeloem-ngeloem; iplv. dit woord tot dibesarkan leest $\mathrm{vE}$ : magroerkan dirinja dari karena radjanja berbesarkan $-3 \mathrm{vE}$ itoe na karena $-\mathrm{N}$ als Tnt. $2-7 \mathrm{~N}$ spelt overal liskar iplv. laskar, een bestaande uitspraak? -8 kedoca, $\mathrm{vE}$ koedanja 
karena - $9 \mathrm{~N}$ calam iplv. cilmoe - soepaja segera, $\mathrm{vE}$ dan tiada $10 \mathrm{v}$ tiada - sadja, vE dan djika dihimpoenkan harta sadja $-11 \mathrm{~N}$ als Tnt. $3-12 \mathrm{v}$. radja itoe dan dihadapannja, $\mathrm{vE}$ dengan segala kelengkapannja - $13 \mathrm{~N}$ als Tnt. 4-dan akan dirinja, $\mathrm{vE}$ sia-sialah hartanja - kesoekaannja, $\mathrm{vE}$ kesoekaran - djikalau dibelandjainja sekalipoen, $\mathrm{vE}$ djikalau sekalipoen dibelandjakan harta $-14 \mathrm{~N}$ ditjarikan iplv. ditjeritakan $-15 \mathrm{~N}$ als Tnt. $5-17$ bentaranjapoen, t.r. tenteranjapoen, vgl. vE: seseorang radja dari pada harta dan dari pada hoeloebalang-hoeloebalang dan tenteranjapoen -17 v. adapoen - harta, $\mathrm{vE}$ (na een arab. spreuk waarvan dit de vertaling is) tiada radja melainkan dengan beberapa laki-laki dan tiada segala laki-laki itoe melainkan dengan harta $-20 \mathrm{~N}$ als Tnt. $7-23$ sentosa, vE sentiasa $-\mathrm{N}$ meréka itoe na soepaja (vgl. Tnt. 8) - 24 djandjinja, $\mathrm{vE}$ segala chabarnja - $26 \mathrm{~N}$ hendaklah - $28 \mathrm{~N}$ als Tnt. 9 - keroegian dan, $\mathrm{vE}$ keras soepaja Allāh tacālā - dari pada kamoe, $\mathrm{vE}$ dari padanja; het woord kamoe is afkomstig van het eind van deze sjarat, dat in de Sal. ontbreekt. - 30 dibitjarakan, $\mathrm{vE}$ membitjarakan.

\section{9}

$2 \mathrm{~N}$ didalam - diperboeat koeasa dan periksa, $\mathrm{vE}$ perboeatan keras dan perkasa -3 ingat, $\mathrm{vE}$ ada $-4 \mathrm{~N}$ hati $-\mathrm{N}$ bitjara -6 barangbarang, $\mathrm{vE}$ seorang orang $-10 \mathrm{~N}$ als Tnt. $1-11$ djadi melarat, $\mathrm{vE}$ berikan sentosa - 13 sama beringat-ingatan samanja, $\mathrm{vE}$ pada sekalian pekerdjaan - 14 sekalian kebesaran radjanja, $\mathrm{vE}$ Allāh tacāla 15 pada - akan, vE bahwa hadir adanja sentiasa - 16 ,déwinja” akan, $\mathrm{vE}$ diketahoeinja bahwa - 17 hati jang baik, vE Hakk soebhānahoe watacāla $-21 \mathrm{~N}$ als Tnt. $2-22 \mathrm{~N}$ dan na élok - 25 djangan mengerdjakan djalan, $\mathrm{vE}$ djaoehkan segala pekerdjaan -29 apabila berkata radjanja, $\mathrm{vE}$ atau ia menengar radjanja berkata $-31 \mathrm{~N}$ als

Tnt. 3-32 N قلق (kelak?) masanja iplv. kalamasanja.

\section{0}

$1 \mathrm{~N}$ als Tnt. $1-2 \mathrm{~N}$ als Tnt. $2-5 \mathrm{~N}$ als Tnt. 3, 4, 5; iplv. perboeatan moet misschien perabotnja gelezen worden. $-6 \mathrm{~N}$ dan na itoe -7 bakalnja, lees bekalnja-10 N terahal iplv. terhal, naar koet. en bdj. uitspraak, 221/32 v. id. - $11 \mathrm{~N}$ iakah iplv. ialah $-13 \mathrm{~N}$ als Tnt. 6-19 iplv. dibawakan verwacht men membawakan; ook in het voorafgaande, aan de Tadjoessalatin ontleende stuk vinden wij enige malen $d i$ - gebruikt, waar $m e$ - mocht worden verwacht $(217 / 8,218 / 30)$. 
$-21 \mathrm{~N}$ parakan (spelling als Bnt. 9) iplv. perarakan $-23 \mathrm{~N}$ itoe na bantalnja - $24 \mathrm{~N}$ oeang belandja itoe djikalau iplv. orang - itoe (vgl. Tnt. 10 en 11) $-27 \mathrm{~N}$ itoe na menteri $-32 \mathrm{~N}$ als Tnt. $12-33$ walang, gewoonlijk vindt men walang (h)ati - 34 soepan (aldus is inderdaad de uitspraak) heeft in koet. de bet. van mal. maloe, bdj. sd. id.

\section{1}

2 memendang, t.r. memandang $-4 \mathrm{~N}$ als Tnt. $1-5$ v. djaoehkan$n j a$, lees didjaoehkannja als 7 en $9 .-9 \mathrm{~N}$ radja $-10 \mathrm{~N}$ dan na radjanja - $11 \mathrm{~N}$ als Tnt. 3 - toempah, letterlijk uitgestort, dan in zijn geheel meegedeeld, overgeleverd. Men zegt in het koet. wel noempahkan cilmoe ke.... als syn. van noeroenkan cilmoe ke... - $12 \mathrm{~N}$ kataannja iplv. perkataannja, lees katanja - $14 \mathrm{~N}$ spelt 15 id., uitspraak nénésnda $-\mathrm{N}$ als Tnt. $5-\mathrm{N}$ tjoetjoeanda iplv. tjoetjoenda, 16, 224/2 id.; vgl. baboeanda, aant. 118/3. - $18 \mathrm{~N}$ eerste itoe ontbr. $-19 \mathrm{~N}$ als Tnt. $6-22 \mathrm{~N}$ als Tnt. $8-28 \mathrm{~N}$ dan na toeboehnja - 30 mengalis kening, koet. de wenkbrauwen bijscheren; ngalis wordt ook gezegd van het scheren van het gehele gelaat, zoals bij een bruid geschiedt. $-32 \mathrm{~N}$ terahal iplv. terhal -33 id. $-35 \mathrm{~N}$ als Tnt. 9.

\section{2}

$1 \mathrm{~N}$ kita na tatkala - N itoe ontbr. - N abus. كان iplv. kata (vgl. Tnt. 1) - $3 \mathrm{~N}$ radjanja $-4 \mathrm{~N}$ kepedas iplv. padas $-8 \mathrm{~N}$ dan na eerste kita - mengadjat, lees mengedjat, koet. steviger aantrekken van de gordelriem, afgeleid van (e)djat = mal. (e)rat. $-13 \mathrm{~N}$ als Tnt. 5; de plotselinge overgang van de eerste naar de derde persoon is een staaltje van de slordige wijze, waarop degeen die passages uit andere werken in de Sal. opnam, te werk is gegaan. $-15 \mathrm{~N}$ pakaiannja $-16 \mathrm{~N}$ als Tnt. $6-\mathrm{N}$ didalam - $17 \mathrm{~N}$ kepedas iplv. kepada - berkata-katanja, lees berkata, katanja - $18 \mathrm{~N}$ dibawasnja iplv. didjawabnja - $19 \mathrm{~N}$ دهوكن iplv. dahoeloe, lees dahoeloekan - $20 \mathrm{~N}$ belari - $21 \mathrm{~N}$ mengidjik iplv. mengedjik, jav. ngèdjèg of ngidjig, in trippelgang gaan. Volgens mijn helpers zegt men te Tenggarong echter ngètjès, wat dezelfde bet. heeft. - $22 \mathrm{~N}$ itoelah iplv. eerste itoe $24 \mathrm{~N}$ als Tnt. $9-25 \mathrm{~N}$ als Tnt. $10-\mathrm{N}$ jang ontbr. $-26 \mathrm{~N}$ dibatisnja iplv. betis; di- is overblijfsel van een slechts gedeeltelijk ver- 
beterde schrijffout en moet vervallen. $-28 \mathrm{~N}$ als Tnt. $12-\mathrm{N}$ djari $-\mathrm{N}$ als Tnt. $13-29 \mathrm{~N}$ hendaklah $-30 \mathrm{~N}$ radjanja $-33 \mathrm{~N}$ enja iplv. ia $-34 \mathrm{~N}$ itoe ontbr. $-\mathrm{N}$ didalam.

\section{3}

3 v. $\mathrm{N}$ sasagoenging iplv. seagoeng jang $-5 \mathrm{~N}$ ngabé iplv. ngabéhi - $\mathrm{N}$ sekaliannja - 6 mendémpok, jav. ndèmpok, plat op de grond gaan zitten (vgl. 226/16) $-9 \mathrm{~N}$ als Tnt. 2, doch na bersama-sama nog dengan Maharadja Sakti serta - $11 \mathrm{~N}$ katanja - $12 \mathrm{~N}$ maka laloelah iplv. laloe $-17 \mathrm{~N}$ mari -20 oedoe, lees oedo; negaro, $\mathrm{N}$ id., t.r. negoro. $-23 \mathrm{~N}$ memandanglah $-26 \mathrm{~N}$ als Tnt. $4-29$ Galidigan (N g.l-), 224/6 id., lees gelédégan; jav. lazvang glèdègan „openstaande deur, die op rolletjes loopt ..... ook naam van twee zijpoorten van de aloen-aloen, die vroeger waarschijnlijk op rolletjes liepen" (GR). Tromp noemt op bl. 11 van zijn inleiding deze ,eerepoort”, waarvan de vermelding volgens hem in de Sal. zou ontbreken, lawang sekéténg, zoals zij inderdaad in de volksoverlevering heet; zo ook $\mathrm{KV} 71$. $\mathrm{N}$ itoe $-31 \mathrm{~N}$ als Tnt. $5-35 \mathrm{~N}$ als Tnt. 6 .

\section{4}

$2 \mathrm{~N}$ tjoetjoeanda - oedoe, lees oedo $-4 \mathrm{~N}$ itoe ontbr. $-5 \mathrm{~N}$ laloelah - $6 \mathrm{~N}$ maka ontbr. - Galidigan, lees gelédégan - $8 \mathrm{~N}$ itoe ontbr. $-9 \mathrm{~N}$ als Tnt. 1 en $2-11 \mathrm{~N}$ djari manisnja iplv. djarinja. manis - $12 \mathrm{~N}$ بركير (? onduidelijk geschreven) iplv. berkisarkisar - $\mathrm{N}$ asoekoe iplv. sikoe - 13 bebahan, lees babahan - N napas - $14 \mathrm{~N}$ selaloelah iplv. laloelah (vgl. Tnt. 5); selaloe betekent in koet. en bdj. tegelijkertijd, in één moeite door. - 20 v. kakanda - lawang behoort tussen aanhalingstekens. $-23 \mathrm{~N}$ besarpoen $-24 \mathrm{~N}$ kakanda $-25 \mathrm{~N}$ adinda $-\mathrm{N}$ als Tnt. $6-26 \mathrm{~N}$ als Tnt. $7-30 \mathrm{~N}$ mana ${ }^{2}-$ $34 \mathrm{~N}$ maka na itoe.

\section{5}

$1 \mathrm{~N}$ als Tnt. 1 - 2 pekenan (N فاكن ), 9, 17, 227/22 id., verhaal in gebonden stijl, zie de inleiding $\S 3$. Iplv. sepa toedjoch leest $\mathrm{N}$ سفاتوتجه توتجه (S id.). Wat voor het waarschijnlijk corrupte سفاتوتج onder invloed waarvan het woord tocdjoeh op zo ongebruikelijke wijze wordt gespeld, gelezen moet worden, weet ik niet. Vermoedelijk hield 
het de naam in van de bepaalde soort pekenan, waarin, zoals in de volgende regels blijkt, precies werd uitgestippeld, hoe de te bouwen kota er zou uitzien. Ongetwijfeld had dit „spel” practische betekenis in een tijd, toen men nog geen pelén ${ }^{1}$ ) tekende, zoals een mijner helpers het uitdrukte. Het gebruik van het woord bcrmain en de duur van zeven dagen en nachten wijst er echter op, dat het ook een soort ritueel was. - $12 \mathrm{~N}$ banjak iplv. banjak-banjak - toedoeh, jav. aanwijzing $-13 \mathrm{~N}$ itoe na toekang $-15 \mathrm{~N}$ als Tnt. $4-$ djaba, koet. $=$ mal. loear (jav.) -17 oembang, koet. bdj. vorm, model $=$ mal. bangoen, waarvan het een omzetting lijkt. $-19 \mathrm{~N}$ jang ontbr. $23 \mathrm{~N}$ als Tnt. $5-26 \mathrm{~N}$ dan ontbr. - $27 \mathrm{v}$. mendjoemenangkan ratoe; Maharadja Soeltan was vóór zijn reis naar Java reeds tot ratoe verheven (191 vv.) en hier gebeurt het nogmaals! Mogelijk liggen hier twee verschillende overleveringen aan ten grondslag. $-28 \mathrm{~N}$ adinda $-29 \mathrm{~N}$ dipolah iplv. diperoléh - 30 v. kembang, 226/3 id., vermoedelijk te lezen kambang, jav. balé kambang, een koepel omringd door water. - $32 \mathrm{~N}$ dan ontbr. $-34 \mathrm{~N}$ berbagai - 35 bertopéng, in de' hier bedoelde bet. van maskerdansen uitvoeren is dit een ongewone vorm; elders vindt men steeds menopéng.

\section{6}

$1 \mathrm{~N}$ als Tnt. 1 - $\mathrm{N}$ masing2lah $-2 \mathrm{~N}$ tweede itoe ontbr. 3 kembang, t.r. kambang? zie 225/30 - bertjantjoet, bet. hier blijkbaar niet gekleed in een tjantjoet, koet. schaamgordel, tjawat, doch naar het jav. „met de kain opgeschort en door de gordel gestoken”; van petola natar wilis is $160 / 12$ een saboek; $251 / 2$ vindt men bertjantjoet poléng bang bintoeloe adji, waarmee de bedoelde wijze van dragen van de kampoeh bedoeld zal zijn, welke immers $131 / 7$ en pass. van deze stof vervaardigd heet. -4 badjoe teratai, volgens Klinkert hetzelfde als $b$. serodja, een baadje met geplooide halskraag, volgens Wilk. is het ,gold-embroidered". Men kent het thans te Tenggarong niet, doch mijn helpers opperden de veronderstelling, dat de thans op de rug van den bruidegom aangebrachte tekens, die teraté worden genoemd (vgl. aant. bij 131/15 kenaka), van het borduurwerk op een dergelijk baadje waren overgenomen. - N برفونتو. , berponto iplv.

1) Dit woord getuigt evenals ponél (stoompijp) en vele andere aan het Engels ontleende woorden voor voortbrengselen der Europese techniek, die in Koetai gebruikelijk zijn, van de invloed der Engelse pioniers, die hier gewerkt hebben. ( $\mathrm{Zie}$ over hen o.a. Dr. R. Broersma, Handel en bedrijf in Zuid- en Oost-Borneo, bl. 166-177). 
berpintoe. In de voornaamste mal. woordenboeken wordt steeds pontoh gespeld, doch verschillende oude mal. teksten geven de spelling zonder h. Zie Sedj. Mel. 95/6, Hik. Radja ${ }^{2}$ Pasai 62/8, hs. Hik. Atjéh 262/5; zo ook steeds bdj. teksten. Vgl. nog md.-mal. en atj. poentoe. Een ponto naga noemen J. en P. IV, 177 onder de Makassaarse armbanden. $-5 \mathrm{~N}$ berkaloeng iplv. eerste bergeloeng - kelinga, drukfout voor kelingan - N m.ngkoer iplv. eerste mangkoer - tweede mangkoer, lees moengkoer $-7 \mathrm{~N}$ oranglah $-12 \mathrm{~N}$ keradjat $-13 \mathrm{~N}$ naiklah $\mathrm{N}$ als Tnt. 5-16 N als Tnt. $6-\mathrm{N}$ منجديمفو iplv. mendémpok, een grafische contaminatie tussen dit woord en mendjelépok (230/7). - $18 \mathrm{~N}$ ia ontbr. - N بردربلد. iplv. berdiri, vgl. aant. bij 193/8 20 v. $\mathrm{N}$ id. iplv. berdirilah $-21 \mathrm{~N}$ mengadap $-23 \mathrm{~N}$ sempoerna $27 \mathrm{~N}$ setinggil $-28 \mathrm{~N}$ beriring $2-30 \mathrm{~N}$ jang ontbr. $-33 \mathrm{v}$. setinggil $-\mathrm{N}$ dipolahkan iplv. dipoelihkan $-35 \mathrm{~N}$ bertelekan iplv. bertalakkan.

\section{7}

$2 \mathrm{~N}$ als Tnt. 1 - berkiau-kiau, 5, 254/17 id., vgl. 227/6/11 berkiau. koet. bdj. (met luider stemme) roepen, gewoonlijk intr.; ngiau $=$ mal. memanggil. $-7 \mathrm{~N}$ koeawa iplv. awak; de vorst stelt hier dus aan zijn volk de vraag, of $z \mathrm{ij}$ hem wel zullen kunnen verdragen als heerser, daar hij zo streng is. $-\mathrm{N}$ als Tnt. $2-9 \mathrm{~N}$ als Tnt. $4-14 \mathrm{~N}$ als Tnt. 5-15 $\mathrm{N}$ als Tnt. $6-20 \mathrm{~N}$ als Tnt. $7-$ kemit is goed (vgl. noot 8) - 21 langkap balai, zie aant. bij $132 / 18$ - $22 \mathrm{~N}$ iplv. berwajang, d.i. nerojong, (grondwoord terojong), koet. verhalen vertellen, dus een heel wat geschikter bezigheid voor wachters dan wajang spelen! Het ongetwijfeld bestaande verschil tussen pekenan en terojong kon men mij niet goed duidelijk maken; de laatste zijn vermoedelijk meer dongèngs, de eerste mythen. - $26 \mathrm{~N} i a$ ontbr. 28 balai itoe mendapa, lees balai mendapa itoe, vgl. 228/15 - sanglir, 228/9 id., hiermee schijnt selir bedoeld te zijn, misschien onder invloed van een niet meer begrepen jav. sanglir sari. De pangkons worden, tegenwoordig althans, niet door selirs gedragen, doch door mensen uit de kampongs Pandji en Djawa.

\section{8}

1 membawa is in $\mathrm{N}$ met het daarop volgende peminangan (een regel verder thuisbehorend) doorgehaald (vgl. Tnt. 1) - menjelampi, lees 
menjelampai - 4 kekoetjoe, $\mathrm{N}$ niet duidelijk كسحو (I als Tnt. 2: kekatjoe); vgl. misschien bal. kekotjor, klapperdop met water om de handen mee te wassen, sas. kotjor, ketel? - kekoclipan? - 5 kendi pertola, jav. kendi pratola, soort van versierde waterkruik, vgl. J. en P. $\mathrm{V}, 99$. - $7 \mathrm{~N}$ sekali iplv. segala, lees sekalian (als Tnt. 4) - $9 \mathrm{~N}$ sanglir iplv. selir - djedjamahan, i.q. djamah-djamahan bij Klinkert en Wilk., vgl. KBW djadjamahan = goendik, jav. djamahan. $-10 \mathrm{~N}$ als Tnt. $5-11 \mathrm{~N}$ mendaklah - $\mathrm{N}$ tweede maka ontbr. - 13 dajang sanaknja, lees met $\mathrm{N}$ diangsanaknja; diangsanas, koet. = dengsanas $=$ mal. saudara, vgl. bdj. dangsanak, min. dansanas. In $232 / 7$ spelt $\mathrm{N}$ t.o. bedajang sanak voor bediangsanak. - $17 \mathrm{~N}$ als Tnt. 6 - barang pandér dipandérkan dan $(\mathrm{N})$ barang goerau digoeraukan, 230/13 id., zie $158 / 26$. - 19 v. $\mathrm{N}$ maka iplv. astananja dan (vgl. Tnt. 7) $-20 \mathrm{~N}$ tinggallah -23 sekalian iplv. segala $-\mathrm{N}$ penggawa $-25 \mathrm{~N}$ ia ontbr: - $26 \mathrm{~N}$ sekalian na saudaranja - $27 \mathrm{~N}$ ia ontbr. - $\mathrm{N}$ masing $28 \mathrm{~N}$ masing 2 lah $-29 \mathrm{~N}$ berbaliklah ia iplv. berbalik $-\mathrm{N}$ als Tnt. 8 - $35 \mathrm{~N}$ itoe ontbr.

\section{9}

$2 \mathrm{~N}$ baroelah $-5 \mathrm{~N}$ toeakoe iplv. toea-toea akoe - kentoel, lees koentoel, jav. de witte koereiger, $=$ koet. kodjoh. $-6 \mathrm{v} . \mathrm{N}$ gagas $^{\mathrm{s}}$ iplv. gegak; kraai en koereiger staan hier als symbolen van de kleuren wit en zwart (vgl. 189/7). De bedoeling is dus: als gijlieden zegt, dat iets wit is, doch ik zeg zwart, dan is het zwart. Ook elders worden deze twee vogels als toonbeelden van wit en zwart beschouwd; zie o.a. KBW sv. koentoel. Een bijna aan de hier gebruikte identieke uitdrukking uit het wetboek van Moko-Moko wordt aangehaald door R.O. Winstedt in JMBRAS IX, 1931, bl. 136 (A Jelebu customary saying): ,when the Raja ,calls a crow (dendang) white it is white, and when he calls white black it is black"." Vgl. ook in een eedsformulier in de Legende van de kris si Gendjé (TBG 48, 1906, bl. 123): selama-lama gagah (sic) Item Koentoel Poetih, aer Ilir garem masin (hoofdletters en spelling naar het origineel), en min. salamo gagas itam, salamo aie ilie (Kamoes sv. gagas). كاولَّْنون iplv. kaoela noewoen, dus kaoelå noen (jav.) - $13 \mathrm{~N}$ dipelas na soedah (vgl. Tnt. 4, waar hierna abus. herhaling) - N Soeltan - $14 \mathrm{~N}$ als Tnt. $5-\mathrm{N}$ maka na léman - $15 \mathrm{~N}$ setinggil - $16 \mathrm{~N}$ itoe ontbr. - N laloe - De woorden serta habis - bersabda schijnen hier niet op hun plaats. - 17 sangkoe 
berwajang, kom met wajangfiguren, waarmee is bedoeld de zodiakbeker, waarin ook thans nog bij het érau het z.g. air toeli wordt gedaan, en die kortweg sangkoe wordt genoemd. Niet te verwarren met de bokor bewajang, de zilveren kom met wajangfiguren, welke bij Tromp, Plaat Vd is afgebeeld. - $\mathrm{N}$ jang na berwajang - air toeli; Tromp verklaart in aant. 177: „water, dat gedurende een feest op geheimzinnige wijze 's nachts uit de rivier wordt gehaald en tot het einde bewaard voor den Sultan, die zich dan daarmee gezicht en handen wascht en het gedeeltelijk drinkt." Het water wordt tijdens een érau niet éénmaal, doch telkens te middernacht door een specialen waardigheidsbekleder in de sangkoe, bedekt door een gele doek, uit de rivier gehaald. De man heeft zelf een gele doek over het hoofd en wordt voorafgegaan door iemand met een kaars in de hand. De weg, waarlangs hij gaat, mag van zijn vertrek tot zijn terugkomst in de kraton door geen sterveling gekruist worden. Om dit te verhoeden worden twee lange touwen door een aantal mannen gespannen gehouden van de kraton tot de rivieroever. Het water wordt bewaard tot de volgende namiddag, wanneer het voor de beloeloeh-ceremonie wordt gebezigd. $\mathrm{Bij}$ het beloeloeh is de Sultan gezeten op een platform van bamboe, en wordt hij met air toeli besprenkeld door de belians en dézwa's, waarna hij ook zelf met een paar druppels water een gezichtwassing schetst. Op de laatste dag neemt hij wat van dat water in de mond en spuwt dit uit op een aan het uiteind gloeiend stuk brandhout (koet. petongot), een zinnebeeld zowel van het doven van alle kwade invloeden als van de beëindiging van het érau. Ook trekt hij bij die gelegenheid een z.g. ketikai lepas los, d.i. een kunstig ketoepat-vlechtsel (koet. ketikai) in de vorm van een bol met twee slippen, dat door trekken aan die slippen makkelijk losgaat. (Vgl. mal. lepas-lepas aan het einde van een huwelijksplechtigheid bij Klinkert en Skeat, Malay Magic 386, en pelepasan in Sambas bij huwelijk of besnijdenis van een vorstentelg, bij Van Prehn, Aanteekeningen betreffende Borneo's Westkust, TBG 7, 1858, bl. 7.) Op deze beloeloch-ceremonie hebben r. 16-21 betrekking. Het water, dat bij deze plechtigheid wordt gebruikt zou zijn eigenaardige naam ontlenen aan het absolute stilzwijgen in de natuur, dat volgens het volksgeloof te middernacht heerst. Zoals uit de beschrijving kan blijken heeft air toeli hier een geheel andere bet. dan in Aanh. vdW opgegeven „de kristalachtige stof in de bamboe soms gevonden": vgl. ook KBW sv. bongol en jav. banjoe toeli. - 19 lepas koeroeng-koeroeng, mijn. helpers kenden de uitdrukking niet, doch maakten uit het verband op, dat hiermee de ketikai lepas is bedoeld (zie vorige aant.) $-21 \mathrm{~N}$ 
dituriknja - laloe sisemboernja, vermoedelijk is hier iets uitgevallen, en is de petongot bedoeld, die zoals in aant. bij r. 17 is opgemerkt, door den Sultan met air toeli wordt bespuwd. - $\mathrm{N}$ laloe oendoerlah iplv. laloelah oendoer - 24 mendjogét; hiermee wordt nog steeds de wijze van dansen der déwa's op gamelanmuziek aangeduid, jav. ndjogèd. Déwa Poeteri danst hier òp de léman, de tegenwoordige dézwa's dansen er slechts omheen. Als vrouw van vorstelijken bloede mocht zij echter de léman betreden (vgl. ook r. 15), zo verklaarde men mij. $-25 \mathrm{~N}$ maka na kali - disintalnjalah; njintal, koet. omwikkelen, vgl. mal. pintal. Of de hier meegedeelde mythe, waarin Déwa Poeteri door de léman wordt omwikkeld en daarna verdwijnt, nog in het hedendaagse ritueel wordt opgevoerd, ben ik niet te weten kunnen komen. $-26 \mathrm{~N}$ eerste itoe ontbr. - $\mathrm{N}$ maka iplv. tweede itoe - $\mathrm{N}$ dibesarkanlah $27 \mathrm{~N}$ itoe na boenji-boenjian - N مسنله , mocsnalah iplv. lenjaplah (vgl. Tnt. 8) -28 itoe - lagi ontbr. (vgl. Tnt. 9) $-29 \mathrm{~N}$ berangkatlah iplv. berangkit - $31 \mathrm{~N}$ laloelah $-33 \mathrm{~N}$ masing 2 lah.

\section{0}

$1 \mathrm{~N} \mathrm{kebalai}$ iplv. kembali; iplv. het volgende mendak zal mendapa gelezen moeten worden, vgl. r. 5-2 N Saktipoen - 2 v. serta dengan Maharadja Indrawangsa dan Maharadja Darmawangsa dan Maharadja Soerawangsa laloelah iplv. ia - laloe (vgl. Tnt. 1) - $7 \mathrm{~N}$ dan na sekalian - mendjelépok heeft hier blijkbaar dezelfde bet. als mendémpok (zie 223/6), vgl. de woordenboeken. - $10 \mathrm{~N}$ toendoeslah $-15 \mathrm{~N}$ als Tnt. $2-16 \mathrm{~N}$ menteri penggawanja sekalian iplv. menterinja sekalian penggawanja $-18 \mathrm{~N}$ als Tnt. $3-\mathrm{N}$ adinda $-24 \mathrm{~N}$ dengan iplv. dan - N masinglah $-25 \mathrm{~N}$ seroepa $-26 \mathrm{~N}$ mimpinja iplv. dengan mimpi (vgl. Tnt. 7) $-31 \mathrm{~N}$ aanhalingstekens reeds na baiklah sluiten. $-35 \mathrm{~N}$ serta iplv. dan.

\section{1}

5 soesoeran dagang, schijnt iets als „boom, aanlegplaats voor handelsschepen" te betekenen; het is echter te Tenggarong niet meer bekend. Vgl. 133/30, waar het de naam van een kampong is. $-6 \mathrm{~N}$ als Tnt. 1 - $7 \mathrm{~N}$ laloelah iplv. maka laloe $-8 \mathrm{~N}$ disaoet oléh iplv. sahoet (vgl. Tnt. 3) $-9 \mathrm{~N}$ ini ontbr. $-10 \mathrm{~N}$ als Tnt. $4-16$ koendjang, koet. kat - $\mathrm{N}$ baï iplv. babi - $18 \mathrm{~N}$ mengandikalah iplv. mengandika poela (vgl. Tnt. 5) $-23 \mathrm{~N}$ siaplah iplv. sampailah $-\mathrm{N}$ als Tnt. $8-24 \mathrm{~N}$ 
als Tnt. 9-26 N maka moestaciblah iplv. moestacid - N besar-besar - $27 \mathrm{~N}$ ngabé iplv. ngabéhi - $\mathrm{N}$ als Tnt. 11, bebekal, in Koetai, althans tegenwoordig, even onbekend als ngabéhi en loerah. Vgl. jav. bekel, soort van dorpshoofd. De geredupliceerde vorm met dezelfde bet., die men niet in de jav. woordenboeken aantreft, vindt men ook in Hik. Radja2 ${ }^{2}$ Pasai $9 \dot{8} / \ddot{8}$ in een opsomming van lage jav. ambtenaren. B's lezing pembekal is een innovatie. Het is het bdj. pambakal, van een jav. (?) pembekel, dat in deze vorm slechts op Lombok in gebruik is. $-28 \mathrm{~N}$ ada segala iplv. adalah hadir (vgl. Tnt. 12) $-29 \mathrm{~N}$ adinda - $30 \mathrm{~N}$ laloe iplv. laloelah ia - $33 \mathrm{~N}$ Karna ontbr. - kita, 34, 236/6 id., koet. beleefd pron. 2e pers., o.a. gebezigd tot ouderen in het algemeen, ook wanneer men zelf van hogere rang is dan de toegesprokene. $-34 \mathrm{~N}$ macsoed, zie aant. bij 198/26.

\section{2}

$2 \mathrm{~N}$ als Tnt. $1-3$ mengaoela, Tromp aant. 44 : „dienaar, volgeling zijn, evenals „magang” op Java” (jav. ngawoela). De weergave met „magang zijn" is de beste, daar men uit vrije wil mengaoela, in tegenstelling tot besoeaka, wat het verrichten van uit de onderworpenheid aan den vorst voortvloeiende verplichtingen aanduidt. In r. 16 en $233 / 26$ wordt het absoluut gebruikt in den zin van ,den vorst dienen, 's vorsten magang zijn". $-4 \mathrm{~N}$ als Tnt. $2-\mathrm{N}$ poela ontbr. $-6 \mathrm{~N}$ Karna ontbr. - $7 \mathrm{~N}$ بدائغ نقا iplv. béda jang sanak (!), t.r. bediangsanak. $-8 \mathrm{~N}$ dibenoea iplv. disitoe $-10 \mathrm{~N}$ als Tnt. $5-11 \mathrm{~N}$ dipolah iplv. diperoléh $-15 \mathrm{~N}$ als Tnt. $6-17 \mathrm{~N}$ als Tnt. $7-18 \mathrm{~N}$ apakah - $20 \mathrm{~N}$ itoe ontbr. - 27 Padoeka Soeri; wie zij was en waar zij vandaan kwam wordt niet nader aangegeven. Men verwarre haar niet met de evenzo betitelde echtgenote van Adji Batara Agoeng Padoeka Nira (Adji Bedarah Poetih). - 31 menghiasi, $\mathrm{N}$ spelt enigszins misleidend - leboe, $\mathrm{N}$ id., t.r. leboeh - 33 tussen maka en sekaliannja, met welk woord $\mathrm{N}$ een nieuwe bladzijde begint, is vermoedelijk iets uitgevallen.

\section{3}

$2 \mathrm{~N}$ als Tnt. $1-4 \mathrm{~N}$ bependjoedjoelah (vgl. Tnt. 2) $-5 \mathrm{~N}$ als Tnt. 3-7 $\mathrm{N}$ djoea ontbr. $-\mathrm{N}$ als Tnt. 4; het meebrengen van zelfs de as uit de kookplaats is volgens mijn helpers een figuurlijke uit- 
drukking om te zeggen, dat er ook maar niet het geringste mankeerde aan de meegebrachte goederen. Vermoedelijk zit er wel meer achter. $9 \mathrm{vv}$. lawang satoe. Het is niet zeker, of de zeven deuren, bij ieder waarvan een bepaald geschenk gegeven moet worden om toegang voor den bruidegom te verkrijgen, letterlijk moeten worden opgevat dan wel figuurlijk. Bij een huwelijk in hofkringen wordt thans in het huis der bruid een aantal slendangs gespannen gehouden om de bruidegomsstoet de weg naar het huwelijksbed te versperren, welke een voor een worden weggenomen, nadat de aanwezige gasten een voldoend geacht bedrag aan geld erin geworpen hebben. - N بنك , benaga, 14 id. iplv. bernaga; bedil benaga is een kanon met handvaten in de vorm van naga's. $-10 \mathrm{~N}$ als Tnt. $5-11 \mathrm{~N}$ als Tnt. $6-12 \mathrm{~N}$ lindoeng doedoek, zo hoog, dat een zittend persoon erachter schuil gaat. In Toev. Oend. B.N. wordt dit selindoeng d. genoemd (vgl. Van Ronkel, Het Adatwetboek van Koetai, bl. 35, waar silindoeng d. gespeld wordt). - $13 \mathrm{~N}$ كلخ كنتا iplv. gagang denta; waarschijnlijk is T's lezing gelang genta de juiste. -14 tangkang, lees tengkang $-\mathrm{N}$ als Tnt. 10 —kaloeng basing (كلوغ باسيغ ) -18 mengaoelkan selamat sempoerna, blijkbaar „plechtig heilwensen uitspreken”, vgl. 234/20 mengaoelkan selamat sempoerna Dézer $A$. $R$. Poeteri; $236 / 20$ mengaoelkan selamat sempoernanja laki isteri beranak tjoetjoe; 236/26 dikaoelkan selamat sempoerna Seri Gembira, e.d. 't Gebruik van een afleiding van kaoel is vreemd. $-20 \mathrm{~N}$ als Tnt. $12-23 \mathrm{~N}$ als Tnt. $13-24 \mathrm{~N}$ als Tnt. 14 $-\mathrm{N}$ radja $-26 \mathrm{~N}$ ia na selamanja -27 miris, koet. = mal. ngeri, jav. id. Beter zou hier passen misit, koet. jaloers, niet bepaald in ongunstige zin, nl. ook iets willen hebben wat men een ander ziet bezitten. $-28 \mathrm{~N}$ enja iplv. $i a-31 \mathrm{~N}$ als Tnt. 15 en 16.

\section{4}

$3 \mathrm{~N}$ als Tnt. $1-6 \mathrm{~N}$ sadja; hierna moet maka berdjaga-djagalah orang worden ingelast of iets dergelijks. $-8 \mathrm{~N}$ seperti iplv. cadat (vgl. Tnt. 3) $-\mathrm{N}$ djoea ontbr. $-18 \mathrm{~N}$ als Tnt. $4-20 \mathrm{~N}$ als Tnt. 5 $-28 \mathrm{~N}$ als Tnt. $6-29 \mathrm{~N}$ dan na laoet $-\mathrm{N}$ als Tnt. $7-30$ didaharnja, bij een actief dahar, evenals dimakannja bij makan. Voor dahar (jav. dahar), dat in 't bdj. het gewone hoge woord voor eten is, gebruikt men in het koet. overigens batoeran (zie 165/32). - $32 \mathrm{~N}$ maka kira iplv. kira-kira - N als Tnt. 9. 


\section{5}

$3 \mathrm{~N}$ membangoenlah $-\mathrm{N}$ als Tnt. $2-6 \mathrm{~N}$ als Tnt. $3-8 \mathrm{~N}$ diadakanlah $-12 \mathrm{~N}$ terseboetlah $-14 \mathrm{~N}$ lama $-15 \mathrm{~N}$ digantikanlah oléh iplv. digantikan - $17 \mathrm{~N}$ menggantikan keradjaan mamanda iplv. mengantikan (vgl. Tnt. 6) - 18 maka dikoempoelkan oranglah kepada mamanda Padoeka Nira, als ons „bij zijn vaderen verzameld worden” in de meest letterlijke zin, vgl. $239 / 13$ en $240 / 19$. - $20 \mathrm{~N}$ itoelah menggantikan iplv. itoe mengantikanlah $-22 \mathrm{~N}$ anak ontbr. -23 ia, lees jang. Voor de perdjandjian (23-30) vgl. 189/29-190/5. - $27 \mathrm{~N}$ terada iplv. tiada $-28 \mathrm{~N}$ als Tnt. $9-29 \mathrm{~N}$ als Tnt. $10-30 \mathrm{~N}$ als Tnt. $11-\mathrm{N}$ racjat $-31 \mathrm{~N}$ kira.

\section{6}

$7 \mathrm{~N}$ radja $-10 \mathrm{~N}$ berbitjaralah ia iplv. berbitjara $-12 \mathrm{~N}$ als Tnt. 1 $-13 \mathrm{~N}$ keradjat $-19 \mathrm{~N}$ bikoe iplv. bigoe $-\mathrm{N}$ segala na dan $-21 \mathrm{~N}$ als Tnt. $2-23 \mathrm{~N}$ als Tnt. $3-24 \mathrm{~N}$ als Tnt. $4-\mathrm{N}$ baboeandanja$26 \mathrm{~N}$ als Tnt. $6-32 \mathrm{~N}$ als Tnt. $7-33 \mathrm{~N}$ als Tnt. 8 en 9; warna djenisnja ( $\mathrm{N}$ djinisnja); warna heeft hier evenals in 't bdj. de bet. van allerlei, vgl. 237/29 warna permainan, allerlei spelen. Vgl. nog bdj. warna-bagai $=$ mal. pelbagai .

\section{7}

$1 \mathrm{~N}$ als Tnt. $1-\mathrm{N}$ demikian -5 membintang, lees membentang $\mathrm{N}$ s.poe ${ }^{2}$ basa iplv. sepoi-sepoi basah $-8 \mathrm{~N}$ besar $-10 \mathrm{~N}$ isterinja $-11 \mathrm{~N}$ als Tnt. $5-12 \mathrm{~N}$ cadatnja $-\mathrm{N}$ sampailah $-13 \mathrm{~N}$ beranaklah $-18 \mathrm{~N}$ tjoetjoe $-\mathrm{N}$ als Tnt. $7-23 \mathrm{~N}$ als Tnt. $8-24 \mathrm{~N}$ als Tnt. 9; vgl. echter r. 18 - toeanda, d.i. het woord toea, koet. oom of tante, ouder dan vader of moeder (zie 249/15) met honorifiek suffix (vgl. snd. toewa, lemes bij oewa, jav. oewa id.) „Oud" wordt in koet. toa uitgesproken. - 25 boléh heeft hier voegwoordelijke functie met de bet. van opdat, zodat, evenals in het bdj.; vgl. $\mathrm{KV} 68 \mathrm{a}-28 \mathrm{~N}$ als Tnt. $10-29 \mathrm{~N}$ dan ontbr. (bis) $-30 \mathrm{~N}$ demikian $-31 \mathrm{~N}$ keradjat $34 \mathrm{~N}$ als Tnt. $11-\mathrm{N}$ itoe ontbr.

\section{8}

$2 \mathrm{~N}$ als Tnt. $1-3 \mathrm{~N}$ als Tnt. $2-4 \mathrm{~N}$ didalam $-\mathrm{N}$ als Tnt. $3-$ $7 \mathrm{~N}$ djoea ontbr. -8 mengadati, 247/34 id., koet. volgens de adat behandelen, de adatgebruiken aan iemand voltrekken, boek. masadati 
id., evenals hier speciaal met het oog op de lijkbehandeling. - $11 \mathrm{~N}$ mamanda $-12 \mathrm{~N}$ penggawa iplv. penggawanja dan $-14 \mathrm{~N}$ datanglah $-18 \mathrm{~N}$ banjak - $\mathrm{N}$ als Tnt. $6-23 \mathrm{~N}$ anak iplv. anakkoe $-\mathrm{N}$ als Tnt. $7-26 \mathrm{~N}$ als Tnt. $8-29 \mathrm{~N}$ djika iplv. djikalau $-32 \mathrm{~N}$ ipoen (gevocaliseerd!) iplv. iapoen. Een latere hand heeft twee stipjes boven de $j$ gezet, er aldus itoepoen (vgl. Tnt. 10) van makende.

\section{9}

$5 \mathrm{~N}$ tinggallah $-12 \mathrm{~N}$ ditaroehnjalah -15 limpah, wordt hier zeer ongewoon gebruikt in de zin van zich alom verbreiden (mare). $-22 \mathrm{~N}$ als Tnt. $3-\mathrm{N}$ tweede isi ontbr. $-25 \mathrm{~N}$ als Tnt. $6-26 \mathrm{~N}$ s.poe 2 iplv. sepoi-sepoi - 27 kepada waktoe itoe moet vervallen, zie de volgende regel. $-31 \mathrm{~N}$ als Tnt. $8-33 \mathrm{~N}$ besar $-34 \mathrm{~N}$ tweede poeloeh ontbr.

\section{0}

$6 \mathrm{~N}$ terseboetlah $-8 \mathrm{~N}$ als Tnt. $1-10 \mathrm{~N}$ als Tnt. $2-11 \mathrm{~N}$ cadatnja - $12 \mathrm{~N}$ mengadas $-16 \mathrm{~N}$ sepoeh, 246/27, 247/12 en pass., hoog woord voor oud, jav. $-18 \mathrm{~N}$ dipeliharakanlah $-\mathrm{N}$ als Tnt. 3 en 4-23 v. empat kampoeng, 244/16, 247/20 kampoeng (jang)empat; dit zijn de kampongs Pandji, Melajoe, Djawa en Kendal; zie over hun bijzondere positie t.o.v. de kraton Tromp bl. 19 en aant. 58. - 28 Toean di Bandang, blijkbaar dezelfde als Datos ri Bandang, die volgens de overlevering in 1606 de Islam aan de Boeginezen bracht. Als het verhaal van zijn bezoek aan Koetai in wezen juist is, zou de islamisatie van dit land dus eerst in het begin der 17de eeuw hebben plaats gevonden, en niet omstreeks 1575, zoals Dr. Mees (bl. 54) aanneemt. T.a.v. den vorst, onder wiens regering Koetai tot de Islam overging, is de overlevering niet eenstemmig. $\mathrm{KV}$ laat het geschieden onder Maharadja Soeltan, Von Dewall vernam, dat het onder Radja Mandarsah (,Adjie di Méndirsa", Ind. Arch. 1e jrg. I, bl. 90) was, doch allen zijn het er over eens, dat Toean Toenggang (Von Dewall „Toengkang”) Parangan de brenger van het nieuwe geloof was. - toean, pass. id., in Koetai was evenals in Bandjar de titel toean, voorzover het Indonesiërs betrof, voor hadji's gereserveerd; 241,8 toean itoe, die hadji. $-29 \mathrm{~N}$ jang ontbr. $-\mathrm{N}$ als Tnt. $6-33 \mathrm{~N}$ als Tnt. $7-\mathrm{N}$ tinggallah $-34 \mathrm{~N}$ als Tnt. 8. 


\section{1}

1 djoekoet, 3 en pass. id., koet. vis = mal. ikan (vgl. vdW). parangan, 4 en pass. id., Tromp aant. 8 vertaalt het met ,zaagvisch". Mees waarschijnlijk juister met „zwaardvis”, welke bet. het woord ook in Beroenai heeft. Zwaardvis en zaagvis worden nog al eens met elkaar verward. $-2 \mathrm{~N}$ berajas iplv. beraja; koet., op bezoek gaan of komen, een visite maken. Vgl. md.-mal. berajas, ,voor zijn genoegen ergens naar toe gaan, kuieren, zonder een bepaald doel van de eene plaats naar de andere gaan" en ook bepaalde adatbezoeken brengen. $-3 \mathrm{~N}$ jang ontbr. $-N$ maka na melihat (waarschijnlijk doorgehaald in het origineel, doch door een vlek in de tekst niet duidelijk) - $6 \mathrm{~N}$ itoe ontbr. - 10 dikerélaï (N دي كريضني ), de vorm, mij van elders niet bekend, is te vergelijken met diketahoeï, dikehendaki e.d. - 11 bajangbajang Allah tacala, vertaling van arab. zilloellāhi filcălam. $-19 \mathrm{~N}$ ia na djikalau - 20 balaman api naraka (koet. uitspr. zou beleman zijn, als jav.), een smeulend stuk hout in de hel, o.a. in de bdj. litteratuur zeer gewone uitdrukking. - $\mathrm{N}$ segalanja iplv. sekalian $-22 \mathrm{~N}$ islampoen -25 de aanhalingstekens behoren vóór orang te staan $-26 \mathrm{~N}$ itoe na islam $-32 \mathrm{~N}$ laloelah.

\section{2}

$4 \mathrm{~N}$ itoe na tweede toean $-5 \mathrm{~N}$ itoe iplv. ia $-9 \mathrm{~N}$ asoekoe iplv. sikoe - bebahan, t.r. babahan - $12 \mathrm{~N}$ itoelah iplv. ini $-17 \mathrm{~N}$ als Tnt. 3-18 Vermoedelijk ontbreken er tussen timbocllah en parangan enige woorden. $-21 \mathrm{~N}$ als Tnt. $4-\mathrm{N}$ katakoe engkaulah iplv. katakoelah (vgl. Tnt. 5) - $27 \mathrm{~N}$ abus. جدين iplv. djadinja - $29 \mathrm{~N}$ als Tnt. 6-33 N akan iplv. ini - N lagi na het eerste saja - menghabisi $243 / 15$ v. id., koet. ngabisi $=$ mal. menghabiskan $-34 \mathrm{~N}$ als Tnt. 7.

\section{3}

$3 \mathrm{~N}$ mintas iplv. mintah $-5 \mathrm{~N}$ berpadahlah iplv. berpindahlah $\mathrm{N}$ dalam ontbr. $-9 \mathrm{~N}$ itoe ontbr. $-13 \mathrm{~N}$ itoe na toean $-15 \mathrm{~N}$ djandjian iplv. djandjinja dengan - $\mathrm{N}$ itoe na Makota - 16 pekasan, drukfout voor pekasam - $17 \mathrm{~N}$ tempajan - $18 \mathrm{~N}$ jang ontbr. -19 bertemoelah zal wegens het gebruik van kepada wel bertamoelah gelezen 
moeten worden. Het is echter evenmin erg sprekend in dit verband, waar men bergoeroe of iets dergelijks zou verwachten. $-\mathrm{N}$ toean na kepada - 20 eerste itoe ontbr. - $21 \mathrm{~N}$ kalimah sjahadat iplv. kelima sjahadah -22 sahih batilnja, lees met de hss. sah batalnja $-28 \mathrm{~N}$ als Tnt. $4-29 \mathrm{~N}$ na besar-besar: soedah habislah sekalian anak radja ${ }^{2}$ dan menteri penggawa dan segala orang besar ${ }^{2}-\mathrm{N}$ banjak iplv. banjak-banjak $-30 \mathrm{~N}$ als Tnt. $6-31 \mathrm{~N}$ dengan ontbr. $-32 \mathrm{~N}$ bala $-\mathrm{N}$ itoe ontbr. $-\mathrm{N}$ als Tnt. $7-33 \mathrm{~N}$ segala na dengan $-35 \mathrm{~N}$ kakal iplv. kekallah.

\section{4}

$1 \mathrm{~N}$ als Tnt. $1-3 \mathrm{~N}$ membawaslah $-4 \mathrm{~N}$ mana $-5 \mathrm{~N}$ itoe ontbr. $-7 \mathrm{~N}$ Loah iplv. Loeak $-8 \mathrm{~N}$ eerste jang ontbr. - kebawahnja en 9 keatasnja, hier resp. noordelijke en zuidelijke richting aanduidend t.o.v. de Mahakamdelta. Deze wijze van oriëntatie was mijn helpers niet bekend. Als men in Koetai van tanah bawah spreekt, dan bedoelt men daarmee de buiten de koeala gelegen kuststreek, die zowel Sangkoelirang als Balikpapan omvat. Dit komt overeen met Sal. 143/19, waar dibawah tegenover didarat staat. - 9 Menoebar $(\mathrm{N})$, een naast het Menoembar der internationale kaart voorkomende uitspraak. $11 \mathrm{~N}$ sekali iplv. sekalian $-12 \mathrm{~N}$ dan na padi - $13 \mathrm{~N}$ als Tnt. $2-$ $15 \mathrm{~N}$ itoe ontbr. $-17 \mathrm{id}$ - -19 ratoe agoeng, 32 id., een als eigennaam te beschouwen titel, vgl. $245 / 8 .-23 \mathrm{~N}$ dan ontbr. -24 id. $-26 \mathrm{~N}$ keradjat - 33 Gantar, lees Gentar - N abus. sapoen iplv. sapoe $37 \mathrm{~N}$ itoe ontbr.

\section{5}

$2 \mathrm{~N}$ sependengaran iplv. sepedengaran; de uitdrukking is ongewoon. - 4 N di Parangan iplv. Parangan (vgl. Tnt. 1) - 5 salat, N صلواة, lees selawat (salawat), arab. صلوات. Onder salazvat verstaat men zegenbeden voor den Profeet, en wel ,endless variations of the theme „May God give blessing and greeting to our Lord Muhammed" " (Snouck Hurgronje, Mekka, translated by J. H. Monahan, bl. 117). Met salawat tiga kali bedoelt men in Maleise streken het driemaal uitspreken van dergelijke zegenbeden van toenemende lengte. Een van de bij een huwelijk (nl. bij het verlaten van zijn ouderlijk huis en bij het betreden van de woning der bruid door den bruidegom) en ook wel bij andere plechtigheden gebruikelijke vormen in het Bandjarse is: 
1. Allāhoemma șalli calā Moehammad

2. Allāhoemma șalli calā rasōlika sajjidinā Moehammad

3. Allāhoemma șalli calā rasōlika sajjidinā wanabījinā waḥabỉbinā wasjafīcinā wazoehrinā (sic) wamaulānā Moeḥammad.

Deze formules worden door één persoon uitgesproken, en telkens door de aanwezigen in koor beantwoord (vgl. de tekst: maka ramailah orang menjahoeti) met "sallin”". In Atjeh is het antwoord van dergelijke zegenbeden (seulaweuët) „salloe calaih", wat een juister gebruik is. (Vgl. Atj. Wdb. sv. salawalé). - 7 poespa pemboedjangan, 21 id., $\mathrm{N}$ spelt het eerste woord als Bnt. 2, terwijl in het tweede woord geknoeid is. Klinkert geeft poespa padjangan of p. pemadjangan, bruidsvertrek, en sv. boedjang: geta peboedjangan en balai p., waarin peboedjangan een verbastering van pemadjangan zou zijn (vgl. ook de in bdj. gebruikelijke vorm papadjangan). Zie ook Wilk. perboedjangan. - $9 \mathrm{~N}$ als Tnt. 3 - keresmian, lees keresmén, litt. jav. mingenot. De in Koetai gangbare bet. van dit woord is vermakelijkheid, vertoning, evenals bdj. snd. karasmin. - $16 \mathrm{~N}$ sampailah $-17 \mathrm{~N}$ dipiasi iplv. dihiasi (vgl. Tnt. 6) - $18 \mathrm{~N}$ itoe ontbr. $-19 \mathrm{~N}$ di Parangan iplv. Parangan $-23 \mathrm{~N}$ als Tnt. $8-26 \mathrm{~N}$ penggawa dan iplv. penggazvapoen - $28 \mathrm{~N}$ tweede isi ontbr. $-\mathrm{N}$ als Tnt. $9-31 \mathrm{~N}$ als Tnt. 12 en $13-\mathrm{N}$ s.poe ${ }^{2}$ iplv. sepoi-sepoi $-32 \mathrm{~N}$ als Tnt. 15 en 16.

\section{6}

$2 \mathrm{~N}$ dan na radja-radja $-3 \mathrm{~N}$ als Tnt. $1-\mathrm{N}$ didalam $-4 \mathrm{~N}$ maka na malam $-8 \mathrm{~N}$ ajahandanja $-10 \mathrm{~N}$ djoea ontbr. $-11 \mathrm{~N}$ als Tnt. $3-12 \mathrm{~N}$ als Tnt. $4-13 \mathrm{~N}$ als Tnt. $5-14 \mathrm{~N}$ als Tnt. $6-$ $15 \mathrm{~N}$ djoea ontbr. $-\mathrm{N}$ als Tnt. $7-16 \mathrm{~N}$ als Tnt. 8- $\mathrm{N}$ bininja $17 \mathrm{~N}$ laki (vgl. Tnt. 9) - Ki Mas, door $\mathrm{N}$ vaak als één woord geschreven, thans geen bekende koet. titel. - N Penggoeloe iplv. Penghoeloe, $249 / 8$ id. $-18 \mathrm{~N}$ als Tnt. $10-19 \mathrm{~N}$ bininja $-\mathrm{N}$ jang na dan - 20 Narsah, elders wordt Narsih gespeld (248/26, 249/15). $22 \mathrm{~N}$ itoe iplv. ada $-\mathrm{N}$ sampai $-\mathrm{N}$ als Tnt. $13-24 \mathrm{~N}$ terseboet $25 \mathrm{~N}$ als Tnt. $14-\mathrm{N}$ anakanda iplv. anak $-33 \mathrm{~N}$ Poero iplv. Poera.

\section{7}

$4 \mathrm{~N}$ lama $-5 \mathrm{~N}$ als Tnt. $1-9 \mathrm{~N}$ cadil iplv. cadilnja dan $-13 \mathrm{~N}$ ia na kembalilah $-17 \mathrm{~N}$ jang na Langgarlah $-20 \mathrm{~N}$ als Tnt. 3 $21 \mathrm{~N}$ didalam $-22 \mathrm{~N}$ jang na kenegeri $-24 \mathrm{~N}$ als Tnt. $4-\mathrm{N}$ keradjat - $26 \mathrm{~N}$ pertama 2 - $30 \mathrm{~N}$ maka na itoe $-32 \mathrm{~N}$ enja iplv. ia 33 tatka, drukfout voor tatkala. 


\section{8}

$2 \mathrm{~N}$ sepoe ${ }^{2}$ iplv. sepoi-sepoi $-8 \mathrm{~N}$ als Tnt. $2-17 \mathrm{~N}$ als Tnt. $4-$ 23 N spelt فاز (Paoe) iplv. Pahoc, pass. id. - 25 batang malang, koet. figuurlijke uitdrukking voor een groot voorvechter, kampioenstrijder, zoals alleen de vorst er mag bezitten. Omdat de lieden van de Paoe hem hun batang malang noemden liet de vorst zijn broeder doden. - N lagi na kemoedian - 25-30 Er staat, dat Adji Dilanggar Toean Narsih liet doden door de Badjaus van Boentang. Omdat dezen bovendien het lijk de haren afsneden (wat niet in 's vorsten opdracht begrepen was), werden zij oeloer. Vgl. Mees' inhoudsopgave, bl. 103, laatste alinea. - $30 \mathrm{~N}$ djoea na saudaranja - $36 \mathrm{~N}$ perempoean seorang laki ${ }^{2}$ iplv. laki-laki - perempoean.

\section{9}

1 v. N perempoean bernama Ratoe Gedé jang laki ${ }^{2}$ bernama Ki Mas Antasari iplv. laki-laki - Gedé - $3 \mathrm{~N}$ poela ontbr. - $4 \mathrm{~N}$ ' iplv. Baloe, dus Balos of Balas. - $6 \mathrm{~N}$ Sekoeti -8 Ad noot 3: "tevoren Penghoeloe genoemd" is onjuist, vgl. N 246/17; met Toean Peng(h)oeloe van $248 / 35$ is een ander bedoeld. - $16 \mathrm{~N}$ Moeara Paoe (vgl. Bnt. 5) - N مغفانكن iplv. mengapalkan, dus mengepalakan, aanvoeren, als hoofd optreden van. - $17 \mathrm{~N}$ taoe ${ }^{2}$ iplv. Pahoe; koet. taoe-taoe is weer te geven met ,zorg ervoor, dat je heel goed.....", evenals mal. baik-baik, bdj. id. en bisa-bisa. - $18 \mathrm{~N}$ als Tnt. $6-$ 19 Vermoedelijk is hier een lacune tussen awak en sekalian, met welk woord $\mathrm{N}$ een nieuwe bladzijde aanvangt. $-21 \mathrm{~N}$ tjoetjoe iplv. tjoetjoekoe, wat er eerst gestaan had. - 22 Mekam, lees Makam - $24 \mathrm{~N}$ terseboet $-\mathrm{N}$ als Tnt. $7-25 \mathrm{~N}$ saudara $-29 \mathrm{~N}$ maka ontbr. berkoempoellah dikoeboerkan, waarschijnlijk verbasterd uit een oorspronkelijk dikoempoelkan, vgl. 235/18. - $30 \mathrm{~N}$ orang $-32 \mathrm{~N}$ anakanda $-34 \mathrm{~N}$ als Tnt. 8.

\section{0}

$1 \mathrm{~N}$ anakda iplv. anakanda $-6 \mathrm{~N}$ als Tnt. $2-8 \mathrm{~N}$ anakanda sekaliannja - $11 \mathrm{~N}$ ajahanda - 13 id. $-\mathrm{N}$ baharoe ontbr. $-14 \mathrm{~N}$ djoea na tiada $-15 \mathrm{~N}$ ajahanda $-16 \mathrm{~N}$ poela ontbr. $-\mathrm{N}$ beberapa - $17 \mathrm{~N}$ dikoeat 2 kannja - 18 peteloeran, blijkbaar een oudere of 
fraaiere vorm van koet. teloran, kuit van het onderbeen, onderbeen in het algemeen. - Na maka staat in $\mathrm{N}$ baharoe, doch dit is doorgehaald (vgl. Tnt. 3) - $19 \mathrm{~N}$ ajahanda - maka ontbr. - 21 boeboet, lees bobot, koet. een gewicht (jav.), volgens Knappert, Beschrijving van de onderafdeeling Koetei (Bijdr. 58, 1905), bl. 607, groot zes kati, volgens mij verstrekte inlichtingen acht kati. $-\mathrm{N}$ djoea na bobot $-22 \mathrm{~N}$ als Tnt. 4, alleen bersoeras ${ }^{\text {s }}$ iplv. bersoerak-soerak -24 merangin, koet. de inleidende ceremoniën en feesten van een érau vieren, vgl. aant. bij 119/30. - $28 \mathrm{~N}$ Pandji - Martapoera ontbr. - $33 \mathrm{~N}$ dan ontbr.

\section{1}

$2 \mathrm{~N}$ dipakaii iplv. dipakaiani (vgl. Tnt. 1) - $4 \mathrm{~N}$ matoe (متو ) iplv. moetoe $-5 \mathrm{~N}$ als Tnt. $3-\mathrm{N}$ als Tnt. $5-6 \mathrm{~N}$ spelt halambak aldus: , wat K's lezing djamboe begrijpelijk maakt. - $8 \mathrm{~N}$ memakai $9 \mathrm{~N}$ als Tnt. 6-14 betoelkan (N بولكن ) lees betelekan (vgl. 226/35).

- $15 \mathrm{~N}$ tempong tawar, iplv. tepoeng t., naar koet. volksuitspraak. $16 \mathrm{~N}$ als Tnt. $8-\mathrm{N}$ djempana maka iplv. djempananja $-18 \mathrm{~N}$ als Tnt. $9-20 \mathrm{~N}$ laloelah $-21 \mathrm{~N}$ astana $-\mathrm{N}$ oranglah iplv. tweede orang - $23 \mathrm{~N}$ banjak $\rightarrow \mathrm{N}$ als Tnt. 10. $-\mathrm{N}$ sempoerna $-29 \mathrm{~N}$ als

Tnt. 11 - $31 \mathrm{~N}$ براث iplv. besar-besar, lees besar²nja - N semoea - 33 id. $-34 \mathrm{~N}$ besar $2 n j a-35 \mathrm{~N}$ jang na sekaliannja.

\section{2}

4 perbakalan, lees perbekelan - $\mathrm{N}$ masinglah $-5 \mathrm{~N}$ radja $-6 \mathrm{~N}$ itoe ontbr. $-8 \mathrm{~N}$ als Tnt. $1-11 \mathrm{~N}$ orang ontbr. $-17 \mathrm{~N}$ radja $2 n j a$ - 19 beradja, een mooi woord voor sendjata (litt. jav.) - $26 \mathrm{Ki}$ Narangbaja, een naam ook bekend uit de Hik. Bandjar (Kiai N. en Kiai Patih N.), zie Cense, De Kroniek van Bandjarmasin, bl. 51 en 90. - Kebajan Sampit, wel te lezen: Ki Bajan Sampit, vgl. Bajan Sampit in de Hik. Bandjar, de naam van een vertrouweling van een vorst (Cense, t.a.p. bl. 81). $-28 \mathrm{~N}$ bergaroe $-\mathrm{N}$ penggaroenja -29 didapan, drukfout voor dipapan - mengeletak ( $\mathrm{N}$ mengelatak), het geluid keletak geven. - 30 bidji ( $\mathrm{N}$ bidjis) pelir, naar koet. bigis pelér = mal. boeah pelir, bdj. bigi pelér. Voor koperen testikels als teken van grote kracht vgl. KBW sv. boedjana (aanh. uit een Anbija-hs.). - 31 $\mathrm{N}$ bergoentjang iplv. berkontjang-kontjang $-\mathrm{N}$ batoe iplv. batok - 
33 peminggi, koet. instrument om hoofdluizen los te krabben en dood te drukken, bestaande uit een vouwbeenachtig toegesneden bamboespaander; sommige exemplaren zijn versierd met ingebrande figuren (peminggi besaroe). Een dergelijk toiletartikel is ook bekend bij de Ngadjoe's, die het patiloe, en bij de Boekits, die het kapoehoet noemen.

\section{3}

2 Aria ( اريا ); volgens $\mathrm{Ni}^{\text {s }}$ Temenggoeng moet overal, waar dit staat $(258 / 35,259 / 16 / 18 / 19 / 20)$, Oeria gelezen worden, wat de algemene uitspraak in Koetai zou zijn. Of dit geheel juist is, betwijfel ik, al is Oeria een bekende koet. titel. - N si na Aria, vgl. 256/4 v. $3 \mathrm{~N}$ tiadalah $-8 \mathrm{~N}$ besar-besar - N Awang Seradjang iplv. Adjang -9 N Ngabéi Tjatjas (vgl. 256/1) iplv. Ng. Tjatja - N spelt hier vرتما voor Seritama, vgl. Tnt. 3 - $13 \mathrm{~N}$ djoea ontbr. - $14 \mathrm{~N}$ itoe ontbr. - $16 \mathrm{~N}$ anak ontbr. $-17 \mathrm{~N}$ als Tnt. $7-18 \mathrm{~N}$ als Tnt. 8$19 \mathrm{~N}$ als Tnt. $9-20 \mathrm{~N}$ kedoea $-22 \mathrm{~N}$ banjak mati iplv. mati banjak $-23 \mathrm{~N}$ itoe ontbr. $-27 \mathrm{~N}$ air na ditepi $-\mathrm{N}$ diliatlah $-28 \mathrm{~N}$ itoe ontbr. - N itoe na oendoer - $29 \mathrm{~N}$ masing 2 lah.

\section{4}

$4 \mathrm{~N}$ besar2nja - N برفديا: iplv. berpada ia, lees berpedaja? (vgl. 162/15) - 6 semoeloe, t.r. semolo, 11, 13 id. $-7 \mathrm{~N}$ maka ontbr. $10 \mathrm{~N}$ itoe ontbr. -11 id. $-12 \mathrm{~N}$ als Tnt. $1-14 \mathrm{~N}$ ditoeangkanlah (vgl. Tnt. 2) - $21 \mathrm{~N}$ itoe na tweede emas - $25 \mathrm{~N}$ mana $2-26 \mathrm{~N}$ orang ontbr. -32 id. $-34 \mathrm{~N}$ als Tnt. $6-36 \mathrm{~N}$ jang na penggawa.

\section{5}

$1 \mathrm{~N}$ als Tnt. $1-7$ didjangani, 8 mendjangani, niet voorkomend in de mal. woordenboeken, een gewoon woord in bdj. mal. teksten, „,verbieden, weerhouden" (vgl. Sj. Hémop 301 A, 373 A, 3161 enz.). In de bdj. spreektaal wordt het evenmin als in de koet. gebruikt. $-8 \mathrm{~N}$ als Tnt. $2-9 \mathrm{~N}$ laloelah $-\mathrm{N}$ als Tnt. $3-10 \mathrm{~N}$ laloelah $-20 \mathrm{~N}$ eerste itoe ontbr. $-23 \mathrm{~N}$ itoe na tweede semoeanja $-24 \mathrm{~N}$ dilihatnja

- 35 N ستيالوه iplv. Satialaoeh, lees echter Setiajoeda (vgl. 253/8) en niet Setiagoena (Mees in noot 6), daar deze immers reeds genoemd is. 


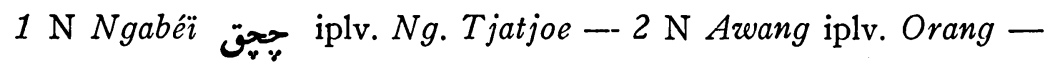
$5 \mathrm{~N}$ als Tnt. 1; peng(h)adapan, koet. degeen tegenover wien men in de strijd komt te staan, tegenstander, mal. lawan. -8 sekali-kali, lees sekali-sekali - $9 \mathrm{~N}$ tangkis - $15 \mathrm{~N}$ dadanja - N Pandji ontbr. 19 mandau, het bekende Dajakse zwaard, zie Tromp aant. 20, Hardeland sv. enz.; de eigenlijke koet. uitspraak is mendau. - $24 \mathrm{~N}$ Awang

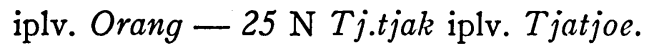

\section{7}

$5 \mathrm{~N}$ als Tnt. $2-13 \mathrm{~N}$ maka na demikian - $15 \mathrm{~N}$ dan ontbr. $16 \mathrm{~N}$ als Tnt. $4-17 \mathrm{~N}$ segala iplv. sekalian - $21 \mathrm{~N}$ dan ontbr. segala orang laki-laki perempoean mengatakan adji datang banjak membawa tawanan dan djarahan orang hoeloe. Deze ogenschijnlijk zo nuchtere woorden roepen bij den Koetainees onmiddellijk het beeld op van een van vreugde dansende en springende menigte, die in de handen klappend juicht: dédés dédong, adji datang! Hoera, de Sultan is aangekomen! $-25 \mathrm{~N}$ als Tnt. $6-27 \mathrm{~N}$ als Tnt. $7-28 \mathrm{~N}$ baarwahkan, bij Klinkert vindt men slechts de vorm mengarwahkan - $31 \mathrm{Ki}$ Narangbaja, blijkbaar een ander dan de dusgenaamde held, die in de strijd tegen Moearakaman lauweren behaalde. In de volgende regels wordt hij slechts Narangbaja genoemd. - 33 v. N Pahak iplv. Paha, ligging? $-34 \mathrm{~N}$ dan iplv. eerste itoe $-35 \mathrm{~N}$ bertanja $-\mathrm{N}$ itoe ontbr.

\section{8}

4 IS als Tnt. $1-6$ I als Tnt. $2-7$ memoelah, lees memolah 10 IS anaknja - 12 IS kepada - 14 IS itoe ontbr. - 18 IS jang iplv. itoe - 19 IS oléh ontbr. - $21 \mathrm{~S}$ dan na Tengahan - 23 IS dan na Oelang - 25 Bangbang, zou t.r. Abang moeten luiden; Adji Bangbang is een titel, waarop in ieder geval een naam behoort te volgen. 26 IS Sakoeti iplv. Sakoeati (vgl. 249/6)._-28 IS تمفاسان , Tempasana, iplv. M.s.pan - 31 I $Y$ iplv. doea (S ontbr.), men leze dus: Ki Djipati Anoem, Ki Djipati Anoem. - 32 S Boeran iplv. Boerat - 34 IS akan na adapoen.

259

1 IS toea (vgl. nt. 1) - 2 IS moeda jang bernama iplv. moe jang nama - 3 IS tjoetjoe - 4 Adji di Toendjoeng, dit is dus de posthume 
naam van Poentjan Karna. - 5 Dérera Poeteri, dit moet zijn (Dézwa Adji) Radja Poeteri, zie bl. 235. - 7 v. I Koetjili, S Koetjang iplv. Koetja, vgl. 249/26. - 9 IS jang na eerste orang - I tia diseboet, $\mathrm{S}$ tiada diseboet iplv. tia di-10 S anak na bernama - 11 IS isterinja iplv. beristeri - 12 IS seorang na orang - 13 I ia na Poetera - 14 IS diperisteri - 15 IS dan jang ontbr. - I laki2, S lagi iplv. laki - IS diperisteri - 19 I anak na eerste dan - I daranja iplv. saudaranja 20 IS diperisteri - IS anak na oléh - 21 IS dengan iplv. di - 22 IS Tempasana iplv. Nampasan (vgl. 258/28) — IS inilah iplv. itoelah 24 S jang ontbr. - 25 IS Lajar - 28 IS ويروييان iplv. di Roebian - 30 IS Bajabaja ontbr. - 31 IS dan na Anoem - 32 sembali drukfout voor kembali.

\section{0}

4 IS Pangéran vóór Ditoe (bis) - 5 Ragi, zou t.r. Regai moeten worden uitgesproken (?). Deze Adji R., de elfde regerende vorst van Koetai, was dus, blijkens de later verkregen titel Ratoe Agoeng, een vrouw. - 6 IS kembali na soedah - 11 IS jang na Adji; B's lezing zal wel de juiste zijn. - $12 \mathrm{~S}$ Ginti iplv. Ganti - 14 Merantjaloeng, beter Marantjaloeng, uitspraak van Moeara Antjaloeng, zoals I hier spelt. - 15 Pantoen, de naam van een stam, welke, naar de heer W. F. van der Kaaden zo vriendelijk was mij mede te delen, zijn woonplaatsen heeft in de districten Moeara Antjaloeng en Moeara Kedang, aan de benedenloop van de Kedang Kepala en de Kedang Rantau. Zij zijn Mohammedanen en worden tot de Koetainezen gerekend. S. C. Knappert geeft in zijn Beschrijving van de onderafdeeling Koetei (Bijdr. 58, 1905, bl. 604) op, dat de vlak bij Moeara Antjaloeng aan de Telén gelegen kampongs Moeara Bangkal en Benoea Baroe ,ook wel Pantoen" genoemd worden. Witkamp vermeldt in De Kedang Rantau (O. Borneo) (TAG. 1928), bl. 50, dat het Pantoens in die kampoengs (hij spelt Moearabengkal) wordt gesproken. Uit het daar ter plaatse en in Een bezoek aan eenige oudheden in Koetei (TAG. 1914), bl. 589, door denzelfden schrijver over het Moeara Antjaloengs meegedeelde mag men wel opmaken, dat de taal een vorm is van het Koetais-Maleis, met eigenaardigheden, o.a. in de uitspraak, die aan het Toendjoengs en zijn verwanten herinneren. - 16 IS $r$ iplv. doea, lees dus: Radén Boengkoek, Radén Boengkoek. - IS Soeramenggala - 17 IS ber- 
poetera iplv. beranak - 25 I Doja, S دوايl iplv. Doenja; I's lezing is de juiste. - IS anaknja na Doja - IS Peta Sebengarang - 26 I orang iplv. Aroeng - 29 IS adapoen ontbr. - 30 Amboet, t.r. Oemboet (zie ook Tromp bl. 17) - 31 IS poeteranja iplv. anaknja - IS jang ontbr. - IS pertama 2 iplv. pernama - $32 \mathrm{~S}$ ديiّn - 33 IS Poentja iplv. Pantja - IS Pegang iplv. Pagang - 34 IS dan na Amdjah.

\section{1}

1 Ampang, t.r. Empang - 2 IS adapoen na Koetai - Amboet, lees Oemboet - IS djoemenangkan - $4 \mathrm{~S}$ دائ , Dajang iplv. Daïng 6 IS djoemenang - I spelt steeds برجنات , S d.i. Berdjanata (of Beradjanata) iplv. Berdjanta - 7 IS na adapoen: Adji Negara djoemenang Adji Emas Tjili (S Tjeki) Adji Andoet djoemenang Adji Gedé adapoen - IS bersocamikan - 8 Kidok, t.r. Kédok - 10 Toeboe, t.r. Tobo - 11 IS ia na soedah - I djoemenangkan, S didjoemenangkan - IS tiada - 13 IS Berdjanata - 14 I Daïng iplv. Dajang 15 IS dan na Wati - 16 IS pertama 2 na kelocaran - IS Tilak iplv. Tila - 17 IS Dali iplv. Wali - IS Adji na kelima - 18 T.pa, t.r. Tepa - IS Adji na keenam - IS dan na Kanderi - 19 IS dan na Liman - IS Adji na ketiga - IS dan na Mertjoe - $20 \mathrm{~S}$ dan na Siroe - IS Tepoe iplv. Tapoe - IS dan na Tepoe - I Adji مودرا (S مودر ), iplv. Am.d.r, t.r. Adji Moedra - 21 I Tjili, S Tjeki iplv. Tjaki - IS didjoemenangkan -- S Aria ontbr. - 23 IS berpoetera iplv. beranak - IS pertama ${ }^{2}$ Adji iplv. peradja - S dan na Ahmad 24 I seorang tiga orang jang iplv. tiga orang $-\mathrm{S}$ dan jang seorang na orang - 27 IS bersoeamikan iplv. beristerikan - 28 I Awerang iplv. Oeang - 29 IS bernama iplv. nama - 30 IS pertama iplv. bernama 33 IS Koendang iplv. Goendang - 34 S.m.n, lees Seman - 35 S Basoe iplv. Basok (I Basos).

\section{2}

$1 \mathrm{~S}$ dan na Negara - I djoemenangkan iplv. tweede didjoemenangkan - $2 \mathrm{~S}$ dan na Negara - IS Oenoes iplv. Oenas - 4 IS beristeri - IS bernama na poela(k) - 7 S N.toeng iplv. K.toen, vgl. r. 18 - 
10 IS seorang na orang - IS seorang iplv. jang - 11 IS اموغ iplv. Moeang, waarschijnlijk Emong naast Mong (r. 25). - I abus. di na Emong - 13 I kembali ontbr. - S di ontbr. - $14 \mathrm{~S}$ djoemenang ontbr. - 18 S Natoeng iplv. K.toen - 20 IS adapoen na Rat - 21 I djoemenangkan - 22 IS terseboetlah - IS didjoemenangkan - 23 IS Ber-

djanata - 25 IS موغ iplv. Moeang, waarschijnlijk Mong, zie r. 11. 26 IS Tjili iplv. Tjiki - 27 IS didjocmenangkan - 28 IS Berdjanata - I $r$ iplv. doea - 30 I 5 iplv. lima - I 3 iplv. tiga - S orang na tiga - 31 I 2 iplv. doea - S orang na doea - IS Pangéran Praboe na adapoen - I 5 iplv. lima - 32 I 3 iplv. tiga - S orang na tiga 33 IS Moehammad Salih-oed-Din ontbr. - I 5 iplv. lima.

\section{3}

3 lepas $b a^{\complement} d a=(h) a b i s b a^{c} d a$, koet. na afloop van de Vrijdagssalat, bdj. limbah bada id. - 6 Padiri, lees Padidi, t.r. (Goenoeng) Pedidi, naam van een kampong in Tenggarong.

\section{4}

Het alleen in B (vgl. Mees bl. 267) voorkomende, niet tot de eigenlijke Salasilah behorende toevoegsel over de tussen de Boeginezen en den Vorst van Koetai gesloten overeenkomst, komt bijna geheel overeen met het eerste gedeelte (vijf der achttien afdelingen) van het „Verslag van het verhandelde tot regeling der betrekkingen tusschen de Maleische en Boegineesche nederzettingen aan de Koetei-rivier onder den vorigen ${ }^{1}$ ) Sultan van Koetei, vertaald uit het oorspronkelijk Maleisch", anoniem verschenen in TBG 24, 1878, bl. 212 vv. Men ver-

1) Dit moet op een misverstand berusten. De sluiting van het verdrag had immers plaats tijdens de regering van den dertienden sultan van Koetai, Pangéran Anoem Pandji Mendapa ing Martapoera, en bovengenoemd artikel verscheen tijdens de regering van den achttienden! Tromp's aanvankelijke aarzeling tussen den dertienden en den twaalfden sultan (zie Eenige mededeelingen, bl.. 176, noot) blijkt reeds van alle grond ontbloot door het gebruik van de naam Ratoe Pemarangan, waar ongetwijfeld dezelfde mee is bedoeld als met Marhoem (Tromp's Geslachtslijst „Meroeh” - natuurlijk een afkorting van Meroehoem, of Merohom, zoals men in Koetai zegt) Pemarangan, de posthume naam van den 13den vorst. Vermoedelijk ontstond het misverstand, doordat Tromp t.a.p. en in de Geslachtslijst den twaalfden sultan Pangéran „Djembajan” noemde, terwijl Pemarangan ook in het Djembajanse is gelegen. Doch de posthume naam van dien vorst is t.r. $\mathrm{Pa}$ ngéran D jembangan, vgl. Sal. 260/7. 
gelijke ook de „Salasila Boegis”, door Tromp uitgegeven en vertaald in zijn artikel „Eenige mededeelingen omtrent de Boegineezen van Koetei", in Bijdr. 36, 1887, bl. 167 vv.

Het valt op, dat de taal van deze ,soerat peringatan" sterk afwijkt van die der Salasilah - hierop is reeds door Prof. Snouck Hurgronje in zijn artikel over de Kroniek, bl. 112, gewezen - en, vooral in de aangehaalde gesprekken, gevoerd tussen den Vorst en de Boeginezen, meer naar het omgangsmaleis zweemt.

13 Anakoda Toedjing; het Verslag spreekt van „den Djoeragan Toedjing”, doch in de Sal. Boegis vindt men „Anachoda Latoedji”. 14 metoea, 16 en pass. id., t.r. matowa, boeg. titel van hoofden. - 23 pazwadoe; 't Verslag spelt Pocadoe, blijkbaar een samentrekking van Poea Adoe, wat men in de Sal. Boegis, bl. 171 aantreft. In laatstgenoemd geschriftje worden de Boeginezen meermalen als poea (d.i. boeg. poewas, vader) aangesproken, terwijl adoe de titel van den matowa in Koetai is (zie Sal. Boegis bl. 169 en 177). - itoe, de nazin ontbreekt. Hier moet inderdaad een lacune zijn, vgl. de woorden van het Verslag. -27 ira, zou het jav. woord kunnen zijn, doch dit is in Koetai geheel onbekend. Bedoeld is air. 


\section{B IJ L A G E}

\section{Bahwa inilah soerat asal keradjaan Koetai djenang-berdjenang.1)}

Maka adalah satoe orang namanja Minak Mampi laki-laki tempatnja tinggal digoenoeng Djaitan Lajar bertapa di Oeringin Gelanggang 2) memintas anak, hingga hari-hari mintas anak, apalah kerdjaan timboen wédjén dan mengamboer beras, demikianlah kerdjaan Minak Mampi. Tiba-tiba itoe hari hoedjan langat 3) waktoe tengah hari, maka adalah kata diawang-awang: „Samboet, djikalau disamboet mati toeha, djikalau tiada disamboet mati moeda." 4) Djadi itoe Minak Mampi terlaloe héran mendengar soeara perkataan diawang-awang demikian itoe, djadi itoe Minak Mampi laki isteri menimboen wédjén dan mengamboer beras, serta Minak Mampi menjahoet, katanja: „Oeloer, djikalau dioeloer mati, tiada dioeloer (mati) djoea." Setelah itoe, maka djatoehlah itoe batoe Angkat-angkatan namanja, kemoedian baharoelah berboenji rantai ring-ring 5) diawang-awang serta dengan raganja. Katanja Minak Mampi : „Oeloer sigera!” Serta beroeloer itoe raga laloe disamboet oléh Minak Mampi, maka adalah dilihatnja satoe orang kanakkanak didalam [didalam] itoe raga serta dengan kerisnja satoe bilah dan tigoe manos setoelang, itoelah banjaknja bawakan 6) Batara Agoeng Déwa Sakti toeroen diatas djangkat, 7) beroeloer didalam raga, serta dipeliharanja oléh Minak Mampi baik-baik, laloe dinamaï Batara Agoeng Déwa Sakti. Tigoe itoepoen menetas, setelah besar itoe manos maka dinamailah Djoeng Pérak Kemoedi Besi. Batara Agoeng Déwa Saktipoen besar.

Maka terseboetlah gandék 8) di Oeloe Doesoen, bininja bernama Baboe Djeloema,9) tempatnja diam di Oeloe Doesoen dan gelarnja itoe gandék Demang Oeloe Doesoen. Tiba-tiba itoe hari Baboe Djeloema hendak berdjerang, tiada berkajoe api. Makanja itoe hari hoedjan tapas 10) toedjoeh hari toedjoeh malam. Maka kata Baboe Djeloema kepada lakinja : „Kita hendak berdjerang, tiada berkajoe api, hoedjanpoen tiada akan tedoeh." Maka Demang Oeloe Doesoenpoen laloe mengambil kasau roemahnja boeat akan kajoe api, serta dipoto'nja, laloe dibelahnja, maka adalah satoe anak oelar keloear didalam itoe kasau, laloe diambil oléh demang diberikannja kepada Baboe Djeloema, 
diboeat akan permainan, laloe ditaroehnja dibawah minangan. 11) Hoedjanpoen laloe tedoeh. Baboe Djeloemapoen laloe berdjerang. Masak nasisnja, laloe makan doea laki isteri. Setelah itoe haripoen malam Baboe Djeloemapoen tidoer doea laki isteri. Setelah hari soedah siang Baboe Djeloemapoen bangoen doea laki isteri dari pada tidoer, laloe bangkit keloear dari dalam kelamboe. Serta dilihatnja itoe anak oelar sesak dibawah minangan, maka ditaroehnja poelas kedalam landjoeng. 12) Setelah sampai tiga hari tiga malam, maka dilihatnja oléh Baboe Djeloema doea laki isteri itoe oelar sesak didalam landjoeng, maka ditaroehnja poelas kedalam koelit. 13) Setelah itoe haripoen malam Baboe Djeloemapoen tidoer, laloe dapat mimpi bertoeroet-toeroet doea laki isteri. Didalam mimpinja itoe oelar [itoelah] berkata-kata dengan dia, maka katanja oelar: „Djikalau kita takoet akan akoe, polahkanlah akoe tangga akan tempatkoe toeroen kedalam air." Setelah itoe Baboe Djeloemapoen terkedjoet, haripoe(n) siang, Baboe Djeloemapoen menjoeroeh lakinja memolah tangga ,akan tempat oelar ini toeroen kedalam air". Maka gandékpoen laloe mengambil kajoe talihan 14) akan tangga. Setelah poepoes itoe tangga oelarpoen toeroen, jaitoe tangga tidak tahan, loros-meloros, 15) patah-mematah, jaitoe oelar poelang poelas ketempatnja didalam koelit. Haripoen malam Baboe Djeloemapoen tidoer doea laki isteri, laloe dapat mimpi bertoeroettoeroet doea laki isteri sebagaimana mimpi jang malam dahoeloe itoe djoega. Baboe Djeloemapoen terkedjoet, laloe bangoen doea laki isteri, haripoen siang, gandékpoen laloe mengambil kajoe talihan 14) diperboeatkannja tangga berasoes ${ }^{s}$ terlebih koeat serta dengan besarnja dari pada tangga jang diperboeatnja dahoeloe. Setelah poepoes itoe tangga diperboeat oléh gandék oelarpoen toeroen, jaitoe tangga tiada djoega tahan, loros-meloros dan patah-mematah djoega, doea kali oelar toeroen tiada sampai keair, oelarpoen poelang ketempatnja. Haripoen malam Baboe Djeloemapoen tidoer doea laki isteri, hatinjapoen soesah serta dengan hérannja melihat hal oelar demikian itoe. Baboe Djeloema laloe bermimpi, didalam mimpinja itoe oelar berkata-kata, demikianlah katanja: ,Ja iboekoe dan bapakoe, djikalau kita takoet akan akoe, polahkanlah akoe tangga akan soepaja akoe toeroen kedalam air, kajoe nama lempong soeit akan indoenja, 16) dan kajoe nama bemboeding akan anaknja, akar nama lemiding akan ikatnja. Dan lagi, djikalau akoe toeroen kedalam air, kita iringkan dengan goebang dan djangan ditinggalkan dimana-mana redaskoe 17) dan djangan berhenti timboen asap 18) dan mengamboer beras dimana ridikkoe, 19) melainkan kita iringkan, djanganlah kita takoet," katanja oelar didalam mimpi Baboe 
Djeloema doea laki isteri, „dan djikalau akoe timboel, ambil dengan sigera-sigera djangan tiada-tiada." Baboe Djeloemapoen laloe terkedjoet doea laki isteri, serta bangoen haripoen siang, gandékpoen pergi mengambil kajoe sebagaimana jang terseboet didalam mimpinja itoe, laloe dipolahkannja tangga. Setelah poepoes itoe tangga kira-kira waktoe tengah hari Baboe Djeloemapoen menimboen asap 18) dan mengamboer beras [tiada ber] tiada berhenti, oelarpoen laloe toeroen kedalam air. Maka baharoelah tangga itoe tahan. Baboe Djeloemapoen laloe mengiringkan doea laki isteri serta mengamboer beras dan menimboen asap tiada berhenti, ridispoen 19) kentjang 20) tiada poetoes. Kira-kira timbangan 21) Tandjoeng Roeana 22) ridispoen penoeh Mahakam, serta balaipoen timboel datang didalam air. Baboe Djeloemapoen laloe mengampiri doea laki isteri itoe balai, jaitoe dilihat oléh Baboe Djeloema doea laki isteri jaitoe naga mendjoendjoeng lemboe, baharoe lemboe mendjoendjoeng balai, baharoe balai [balai] mendjoendjoeng gong. Maka adalah satoe orang kanak-kanak perempoean doedoek diatas gong papar, lapis ${ }^{s}$ ja kain koening dan toedoengnja kain koening djoea. Maka adalah jang dinamai orang karang mendoengkoel 23) itoe, gong diatas, karang dibawah, itoelah banjaknja jang dilihat oléh Baboe Djeloema laki isteri. Serta itoe kanak-kanak diambil oléh Baboe Djeloema serta dengan gong papar dan kain koening dan karang mendoengkoel, itoelah banjaknja jang diambil oléh Baboe Djeloema serta dibawa'snja poelang ketempatnja di Oeloe Doesoen serta dipeliharakannja dengan sepatoetnja. Maka dinamaï oléh Baboe Djeloema itoe kanak-kanak Poeteri Karang Melenoe. Sehingga berapakah lamanja itoe Poeteri Karang Melenoepoen soedah besar.

Maka terseboetlah tjerita Batara Agoeng Déwa Sakti tempatnja digoenoeng Djaitan Lajar soedah besar, mano'nja jang bernama Djoeng Pérak Kemoedi Besi itoepoen soedah besar. Tiba-tiba itoe hari Batara Agoeng Déwa Saktipoen tertidoer waktoe tengah hari, laloe bermimpi dirongkop 24) harimau, 25) ditjaboetnja kerisnja, laloe diladaukannja 26) kepada harimau didalam mimpinja itoe, terkena kepada tadjau kang, 27) laloe petjah. Maka keris itoe dinamai Boerit Kang. 28) Mano'snjapoen lepas djoea, ada satoe kanak-kanak mengiringkan itoe manos. Batara Agoeng Déwa Saktipoen terkedjoet dilihatnja tadjau kang belah terkena ladaunja 29) dengan keris, manosnjapoen lepas. Adapoen itoe kanak-kanak mengiringkan itoe manos sampai toeroen goenoeng, naik goenoeng. Jaitoe manos djikalau kanak-kanak itoe djaoeh ditoenggoenja, djikalau dekat lari itoe mano ${ }^{5}$, hingga demikianlah halnja kanak-kanak itoe dengan itoe manos. Laloe menoedjoe 
ketempat Poeteri Karang Melenoe di Oeloe Doesoen. Serta sampai ketempatnja itoe Poeteri, tiba-tiba itoe manos laloe masoek kebawah roemah Poeteri, laloe mendjantan 30) manos Poeteri. Kanak-kanak itoepoen laloe hendak menangkap manos itoe, Poeteripoen toendoek kebawah roemah dilihatnja ada satoe orang kanak-kanak dibawah roemahnja hendak menangkap itoe manos, maka kata Poeteri kepada itoe kanak-kanak: „Djanganlah awa ${ }^{s}$ tangkap itoe manos. tiada boléh. akoelah jang poenja itoe manos." Maka katanja kanak-kanak itoe: „Apakah sebabnja? Karena ini manos Adji Batara Agoeng Déwa Sakti jang poenja.” Maka kata itoe Poeteri: „Baiklah awas poelang kanak-kanak padahkan kepada Batara Agoeng Déwa Sakti cadatnja orang laki-laki mengikoet orang perempoean." 31) Maka kanak-kanak itoepoen tjengang 32) keatas, dilihatnja ada satoe orang poeteri terlaloe baik roepanja, air pinang ditelannja berbajang-bajang laloe diléhérnja tjahajanja gilang-gemilang. Kanak-kanak itoepoen laloe tandjal 33) melihat tjahaja Poeteri demikian itoe, laloe ditebaknja 34) dengan sepah itoe kanak-kanak oléh Poeteri, kanak-kanak itoepoen laloe bangoen. Katanja itoe Poeteri kepada itoe kanak-kanak: „Padahkanlah kepada Batara Agoeng Déwa Sakti demikianlah cadatnja orang."

Maka kanak-kanak itoepoen laloe bangkit berdjalan poelang ketempatnja digoenoeng Djaitan Lajar. Batara Agoeng Déwa Saktipoen menoenggoe dimoehara lawang. 35) Kanak-kanak itoepoen datang dilihatnja ada Batara Agoeng Déwa Sakti menoenggoe dimoehara lawang. Maka kata Batara kepada itoe kanak-kanak: „Dimanakah manoskoe? Djikalau tiada itoe manoskoe, awas mesti koeboenoeh." Maka sahoet [oléh] itoe kanak-kanak: „Ipoen, 36) tetapi patik hendak bertjerita dahoeloe, baharoelah patik diboenoeh." Katanja Batara Agoeng Déwa Sakti : „Baiklah”. Laloe kanak-kanak itoepoen laloe bertjerita: „Itoe manos patik iringkan, djaoeh-djaoeh patik ditoenggoenja, dekat-dekat patik lari itoe manos, hingga demikianlah halnja itoe. Laloe sampai ketempatnja Poeteri, manos itoepoen laloe masoek kebawah roemah Poeteri, laloe mendjantan 30) manos Poeteri Karang Melenoe. Serta hendak patik tangkap itoe manos, maka kata Poeteri: „, „Hai kanak-kanak, djanganlah awas tangkap itoe manos, tiada boléh, akoelah jang poenja itoe manos, karena soedah masoes kedalam kandang manoskoe." " Patik laloe tjengang 32) keatas roemah, laloe patik terlihat kepada itoe Poeteri, patikpoen laloe tandjal 30) karena terlihat kepada tjahajanja itoe Poeteri terlaloe baik roepanja, air pinang ditelannja berbajangbajang laloe diléhérnja, gilang-gemilang roepa tjahajanja. Laloe ditebaknja 34) patik dengan sepahnja, baharoelah patik ingat serta bangoen. 
Maka kata Poeteri kepada patik: , „Padahkanlah kepada Batara Agoeng Déwa Sakti itoelah cadatnja orang laki-laki mengikoet orang perempoean." " Katanja kanak-kanak kepada Batara: „Itoelah halnja manos itoe." Maka kata Batara Agoeng Déwa Sakti kepada itoe kanak-kanak: „Benarkah?” Maka sahoet kanak-kanak: „Ipoen, 37) benar, djikalau lain dari pada itoe hingga boenoehlah patik!" Maka Batara Agoeng Déwa Sakti berpadah kepada Petinggi doea laki isteri: „Akoe ini hendak mengambil manoskoe ditempat Poeteri di Hoeloe Doesoen." Maka sahoet Petinggi doea laki isteri : „Baiklah”. Laloe Batara Agoeng Déwa Sakti bangkit berdjalan serta diiringkan oléh itoe pengoegoe 38) mano's nja itoe menoedjoe ketempat Poeteri Karang Melenoe di Hoeloe Doesoen. Setelah datang itoe Batara Agoeng Déwa Sakti ketempatnja itoe Poeteri Karang Melenoe, maka dilihatnja oléh Batara Agoeng Déwa (Sakti) Poeteri itoe doedoek diatas ajoen papan 39) serta menioep soeling dan ringkoe bajan. 40) Maka Batara Agoeng Déwa Saktipoen termenoeng mendengar soeara soeling dan ringkoe bajan 40) Poeteri. Maka kata Batara Agoeng Déwa Sakti kepada itoe kanak-kanak: „Benarlah tjeritamoe apa jang terseboet.” Makanja itoe kanak-kanak tiada djadi diboenoeh oléh Bata(ra) Agoeng Déwa Sakti karena pertjeritaannja itce benar semoeanja. Maka Batarapoen naik keroemah serta dekat kepada Poeteri, maka kata Batara Agoeng Déwa Sakti : „Poeteri polés 41) jang diam disini." Maka Poeteripoen terkedjoet melihat Batara Agoeng Déwa Sakti berdiri dekat kepadanja. Sehingga ma'loemlah antara Batara Agoeng Déwa Sakti dengan Poeteri Karang Melenoe, haripoen malam.

Maka terseboetlah Minak Mampi doea laki isteri tempatnja diam digoenoeng Djaitan Lajar terlaloe soesah hati karena Batara tiada akan datang. Soedah sampai tiga hari Batara Agoeng Déwa Sakti tiada djoeakan datang, Minak Mampipoen berdjalan doea laki isteri menoedjoe ketempat Poeteri dan Batara di Hoeloe Doesoen. Setelah datang Minak Mampi ketempat Baboe Djeloema, serta naik keroemah, jaitoe dilihat oléh Minak Mampi doea laki isteri Batara Agoeng Déwa Sakti doedoek diatas ajoen papan 39) dengan Poeteri Karang Melenoe, sehingga moefakatlah Minak Mampi doea laki isteri dengan Baboe Djeloema doea laki isteri dari hal Batara Agoeng Déwa Sakti dengan Poeteri Karang Melenoe dengan sepatoetnja pekerdjaan jang baik. Sehingga berapakah lamanja Poeteripoen beroléh anak satoe orang laki-laki, laloe dinamai Adji Beramboet Kawat. 42) Adapoen Batara Agoeng Déwa Sakti tiada apa-apa perkerdjaan sehingga djikalau hari siang pagi-pagi pergilah melajang kemana-mana negeri orang membawa 
itoe manosnja pergi bersaboeng. Tiba-tiba berkata Poeteri kepada Batara Agoeng Déwa Sakti, katanja: „Djanganlah andika perkerdjaan demikian itoe, djikalau andika lagi hendak bersama-sama dengan patik didalam doenia ini." Batara Agoeng Déwa Sakti tiada perdoeli. Sampai tiga kali Poeteri melarang, tiada djoega Batara Agoeng Déwa Sakti perdoeli. Tiba-tiba Batara Agoeng Déwa Sakti melajang ketanah Djawa pergi bersaboeng. Itoe hari Poeteri Karang Melenoe berpadah kepada Baboe Djeloema doea laki isteri, katanja: „Akoe ini hendak mangkat poelang kedalam air, karena akoe tiada kawa tjampoer-tjemah. 43) Adapoen anakkoe djikalau ia menangis, toendoekkanlah 44) kedalam tadjau ini." Sehingga Baboe Djeloema doea laki isteri tiada berkata mendengar perkataan Poeteri Karang Melenoe demikian itoe. Makanja Poeteri laloe mendjampi anaknja. Adapoen Adji Beramboet Kawat tidoer, Poeteripoen laloe naik keatas ajoen papan, laloe menimboen asap dan mengamboer beras, toedjoeh kali kedjoeroe, toedjoeh kali kepintoe beroembas 44a) dengan ajoen papan, laloe toeroen masoek kedalam air. Adapoen Batara Agoeng Déwa Sakti itoe hari kalah bersaboeng, serta ada tanda calamat datang kepada dirinja. Laloe Batara Agoeng Déwa Sakti melajang poelang ke Koetai. Setelah datang itoe Batara Agoeng Déwa Sakti serta naik keroemah, jaitoe dilihatnja Poeteri tiada, bertanjalah Batara Agoeng Déwa Sakti kepada Minak Mampi : „Kemanakah hilangnja Poeteri Karang Melenoe?” Sahoet Minak Mampi: „Poeteri soedah mangkat poelang kedalam air.” Makanja Batara Agoeng Déwa Saktipoen termenoeng mendengar hal keadaan Poeteri demikian itoe. Batara Agoeng Déwa Saktipoen berpadah kepada Minak Mampi doea laki isteri dan kepada Baboe Djeloema doea laki isteri, katanja: „Akoe ini hendak hilang menoentoeti Poeteri Karang Melenoe masoek kedalam air itoe anakkoe kita peliharakanlah baik-baik." Serta ia menimboen wédjén dan mengamboer beras toedjoeh kali kedjoeroe, toedjoeh kali kepintoe, Batarapoen laloe toeroen masoek kedalam air. Tinggallah Baboe Djeloema doea laki isteri dan Minak Mampi doea laki isteri memeliharakan Adji Beramboet Kawat. Sehingga berapakah lamanja Adji Beramboet Kawatpoen soedah besar, sehingga sampailah soedah roemadja poetera.

Maka tinggallah tjerita Adji Beramboet Kawat, terseboetlah tjerita ada satoe orang toeha berboeroe di Bengalong, 45) kojo'njapoen menjalas direbak petong, sampai toedjoeh hari toedjoeh malam kojosnja itoe tiada berhenti menjalas. Tempatnja itoe petong di Mengkaning 46) namanja. Makanja itoe orang toeha terlaloe sakit hati melihat hal perboeatan $\mathrm{kojo}^{\mathrm{s} n j a}$ demikian itoe, laloe ditebangnja itoe petong serta 
dibawa nja moelang keroemahnja. 47) Maka baharoelah itoe (kojos) mengiringkan djoea sama-sama moelang. Setelah sampai keroemahnja itoe orang toeha, laloe ditaroehnja itoe petong baik-baik. Setelah sampai toedjoeh hari kira-kira waktoe tengah hari, maka toeroenlah hoedjan langat 3) rintis-rintis basah, maka petong [itoe] itoepoen belah meletoep, maka orang toeha itoepoen tertjengang 48) kepada itoe petong, maka terlihatlah ia ada satoe kanak-kanak perempoean keloear didalam itoe petong, laloe diambilnja oléh itoe orang toeha serta dipeliharakannja baik-baik. Laloe dinamai Adji Bedarah Poetih. 49) Maka beberapakah lamanja besarlah soedah Adji Bedarah Poetih sampailah soedah naik. 50 )

Maka terseboetlah tjerita Adji Beramboet Kawat ada mendengar soeatoe chabar jang tentoe, ada satoe orang poeteri namanja Adji Bedarah Poetih tempatnja diam didalam soengai Bengalon, jaitoe Adji Beramboet Kawat laloe menjoeroeh hendak berbini. Setelah sampai itoe soeroehan kepada Adji Bedarah Poetih, maka kata Adji Bedarah Poetih: „Hendak djoea akoe berlaki, tetapi bawakanlah badjoekoe ini kepada Adji Beramboet Kawat, djikalau boléh badjoekoe ini masoek kebadannja, serta akoe memintas soemahan tadjau toeha didjadjarkan toelas di 51) Koetai Lama sampai kemoehara Bengalon, 52) sehingga djadilah kami berlaki bini." Maka soeroehan itoepoen moelang membawa perkataan Adji Bedarah Poetih datang kepada Adji Beramboet Kawat. Setelah datang itoe soeroehan kepada Adji Beramboet Kawat bertjeritalah itoe soeroehan kepada Adji Beramboet Kawat akan segala pertjeritaan Adji Bedarah Poetih serta ada membawa sehelai badjoe: „Djikalau boléh ini badjoekoe masoes kebadannja Adji Beramboet Kawat, maka djadilah kami berlaki bini." Setelah Adji Beramboet (Kawat) mendengar pertjeritaan demikian itoe, laloe terpakoer, jaitoe Adji Padoe(ka) Ningra 53) besar dadanja toedjoeh bidas, 54) maka badjoe itoepoen boléh masoek dengan kodrat Allah ta ${ }^{5}$ ala semoeanja diadakan oléh Adji Padoeka Ningra apa jang terseboet, [dan] tetapi itoe tadjau koerang serantau. 55) Sehinggalah djadilah berlaki bini Adji Beramboet Kawat dengan Adji Bedarah Poetih.

Sehingga beberapakah lamanja antara orang kedoea itoe sampai beroléh anak toedjoeh orang, lima laki-laki, doea perempoean. Adapoen jang toeha sekali namanja Maharadja Sakti dan baharoe Maharadja Soeradiwangsa 56) dan baharoe Maharadja Inderawangsa dan baharoe Maharadja Darmawangsa dan baharoe Maharadja Soeltan dan baharoe jang perempoean namanja Déwa Poeteri dan baharoe Poeteri Déwa. 57) Sehingga beberapakah lamanja besarlah soedah Maharadja Sakti dan 
sekalian saudaranja jang enam itoepoen besar djoea. Tiba-tiba Maharadja Sakti moefakatlah dengan segala saudaranja, maka katanja Maharadja Sakti : „Adapoen kehendakkoe Maharadja Soeltan baik kita djadikan radja, kita jang lain inilah memangkoenja." Dan sahoet Maharadja Soeradiwangsa: „Tiadalah akoe hendak," dan sahoet Maharadja Inderawangsa: „Beloem patoet Maharadja Soeltan didjadikan radja,” dan menjahoet poela Maharadja Darmawangsa: „Maharadja Soeltan lagi moeda, tiada boléh didjadikan radja, karena besar maksoetnja, djadi haroe-hara tachta keradjaannja." Maka katanja Maharadja Sakti: „Djikalau begitoe bitjara kita sekalian, baik kita orang lima bersoempah soepaja djangan bersalahan toeroen-temoeroen djenang-berdjenang." 1) Maka laloelah sida 58) orang lima bersoempah serta menimboen wédjén dan mengamboer beras, laloe terseboet soempahnja Maharadja Sakti serta dengan sekalian saudaranja: „Djikalau anak tjoetjoe Maharadja Soeltan doerhaka kepada anak tjoetjoe kita toeroen-temoeroen djenangberdjenang, tiada selamat serta tiada sempoerna diatas tachta keradjaannja, dan djikalau anak tjoetjoe kita demikian djoea: djikalau ia doerhaka kepada anak tjoetjoe Maharadja Soeltan toeroen-temoeroen djenang-berdjenang, sehingga terkenalah soempah jang [jang] demikian itoe." Serta Maharadja Sakti menimboen wédjén dan mengamboer beras, sehingga tetaplah moefakatan Maharadja Sakti mendjadikan Maharadja Soeltan radja jang amat besar ditanah Koetai Karta Negara rama negerinja.

Tiba-tiba itoe Maharadja Sakti ada mendengar chabar jang amat njata: ada satoe radja ditanah $D$ jawa namanja Ratoe Maharadja Pait, 59) adapoen cadatnja terlaloe baik. Djadi Maharadja Sakti moefakat dengan Maharadja Soeltan dan kepada segala saudaranja, maka menjahoet Maharadja Soeradiwangsa : „Patik orang tiga ini tiada pergi mengiringkan hingga tinggal di Karta Negara." Setelah itoe haripoen baik, waktoe tengah hari Maharadja Sakti dan Maharadja Soeltan menimboen wédjén dan mengamboer beras, serta melajanglah Maharadja jang kedoea itoe menoedjoe kenegeri Ratoe Maharadja Pait ditanah Djawa. Kira-kira ditengah awang-awang Maharadja Soeltan terlihat kepada soeatoe tjahaja terdjali,60) maka kata kepada Maharadja Sakti : "Jaitoe apakah namanja ?" Maka sahoet Maharadja Sakti : „Itoelah jang bernama tédja," laloe dikidjapinja,61) tiada perdoeli, serta ditjenganginja 62) tédjapoen dekat, Maharadja Saktipoen menoenggoe dengan Maharadja Soeltan. Katanja Maharadja Sakti kepada Maharadja Soeltan: „Adapoen [pe]pesan orang toeha ${ }^{2}$ jang dahoeloe: djikalau tjahaja hantoe atawa tjahaja djin atawa indera tjindera 63) 
atawa déwa mambang, melainkan hantjoer; koepandang ini tédja djangankan hantjoer mangkin dekat, barangkali ini tjahaja déwa kemanoesan." Sehingga Maharadja Inderamoeliapoen dekat bertemoelah orang tiga itoe ditengah awang-awang. Maka katanja Maharadja Soeltan: „Datang dimana?” Maka sahoet Maharadja Inderamoelia: „Datang di Moehara Kaman.” Maka katanja Maharadja Sakti : „Hendak kemana ?” Maka sahoet Maharadja Inderamoelia: „Hendak pergi ke Ratoe Maharadja Pait ditanah Djawa hendas meminta cadat." Katanja Maharadja Sakti: „Akoepoen hendak pergi kesitoe djoea, baiklah kita bersama-sama pergi melajang ketanah Djawa." Djadi Maharadja jang tiga itoe bersama-sama melajang menoedjoe ketanah Djawa tempatnja Ratoe Maharadja Pait. Maka katanja Maharadja Soeltan: „Baiklah kita orang tiga mentjoba naik kekajangan gelap jang diatas sekali." Maharadja Soeltan dan Maharadja Sakti naik laloe keatas kajangan gelap, adapoen Maharadja Inderamoelia tinggal ditengah awang-awang, tiada boléh mengiringkan. Djadi Maharadja Sakti toeroen mentjari Maharadja Inderamoelia ketinggalan ditengah awangawang, maka bertemoelah dengan Maharadja Inderamoelia ditengah awang-awang. Maka kata Maharadja Sakti: „Baiklah kita sigera terbang," maka melajanglah itoe Maharadja jang tiga.

Maka terseboetlah tjerita orang dinegeri Djawa, radjanja bernama Ratoe Maharadja Pait serta dengan hoeloebalang menterinja. Tiba-tiba ratoe Maharadja Pait ada melihat tédja terdjali, laloe segara dikidjapinja oléh Maharadja Pait, maka katanja: „Djikalau ini tjahaja hantoe, hilang, dan djikalau tjahaja djin, hantjoer, dan djikalau tjahaja déwadéwa, djaoeh tiada dekat, djikalau akoe kidjapinja atau akoe pandang." Maka itoe tédja djangankan djaoeh mangkin dekat. Maka katanja Ratoe Maharadja Pait: „Barangkali ini tjahaja déwa kemanoesan.” Tédja itoepoen laloe hilang. Maka terseboetlah tjerita Maharadja jang tiga itoe melajang soedah sampai tiga hari sampailah soedah kepinggir negeri. Tiba-tiba Maharadja jang tiga itoe pergi mengadap Ratoe Maharadja Pait jaitoe témpo Ratoe Maharadja Pait doedoek diatas astinggil 64) dihadap oléh demang dan temenggoeng dan penggawa menteri sekalian. Maharadja jang tiga itoepoen datang serta mengadap kepada Ratoe Maharadja Pait, tetapi tiada masoek kedalam balai, hingga doedoek ditanah, sebab melihat atoeran penggawa menteri jang banjakbanjak itoe mengadap Ratoe Maharadja Pait. Tiba-tiba itoe hari barat serta dengan hoedjannja terlaloe lebat tiada terkira-kira, maka Maharadja jang tiga itoe masing-masing menoeroenkan kesaktiannja, hendak berangkat lari, maloe kepada orang jang banjak-banjak. Djadi Maha- 
radja Sakti awan poetih toeroen memajoengi, dan Maharadja Inderamoelia ditjaboetnja kerisnja dikelilingkannja diatas kepalanja tiga kali, djadi Maharadja Sakti dengan Maharadja Inderamoelia tiada basah. Adapoen Maharadja Soeltan basah semoea badannja, tetapi tanah tempat Maharadja Soeltan itoe jaitoe menjorong keatas, sama tingginja dengan astinggil 64) tempat Ratoe Maharadja Pait doedoe(k). Hoedjanpoen laloe berhenti, djadi orang jang banjak-banjak itoe terlaloe héran dan Ratoe Maharadja Pait demikian djoea, terlaloe héran serta tertjengang melihat keadaan Maharadja jang tiga itoe. Katanja Ratoe Maharadja Pait kepada menterinja: „Orang tiga itoe panggil, soeroeh naik kebalai." Menteri itoepoen laloe memanggil. Dengan sigera Maharadja jang tiga orang itoepoen laloe naik serta doedoek dekat dengan Ratoe Mahara(dja) Pait. Serta Maharadja Pait bertanja kepada Maharadja Sakti: „Datang dimana?” Maka sahoet Maharadja Sakti: „Datang di Karta Negara ditanah Koetai sebelah timoer.” Maharadja Pait bertanja poelas kepada Maharadja Inderamoelia: „Datang dimana ?” Maka sahoet Maharadja Inderamoelia: „Datang di Moehara Kaman." „Apakah maksoet datang kemari ?” Sahoet Maharadja Inderamoelia: „Hendak mentjatoe cadat kepada Ratoe Maharadja Pait, karena negeri Moehara Kaman tiada cadatnja." Maka bertanja poelas Ratoe Maharadja Pait kepada Maharadja Sakti: „Apakah permintaan datang kemari ?” Maka sahoet Maharadja Sakti : „Hingga diharap[a]lah akan beriboe-riboe mentjatoe cadat, serta harap akan dikoerniai dibawah kaoes Ratoe Maharadja Pait, karena ada mendengar chabar ada cadat radja ditanah Djawa terlaloe baik antara ( $\mathrm{ra}$ )dja dengan penggawa menterinja serta dengan désa racjatnja 65) sekalian, karena tanah Koetai beloem tentoe cadatnja, karena saudara patik Maharadja Soeltan ini hendak patik djadikan radja di Karta Negara, itoelah keadaannja djadi pergi mengadap Ratoe Maharadja Pait." Makanja Ratoe Maharadja Pait termenoeng mendengar perkataan Maharadja Sakti demikian itoe, maka kata Ratoe Maharadja Pait: „Baiklah apa-apa maksoet kita sekalian soedah akoe mendengar, tetapi akoe hendak bertanja lagi kepada Maharadja Inderamoelia: satoe soengaikah dan satoe tanahkah Moehara Kaman dengan Karta Negara atau berlainankah tanah antara itoe negeri jang kedoea?" Maka sahoet Maharadja Inderamoelia: "Satoe soengai dan satoe tanah, tiada berlainan." Katanja Ratoe Maharadja Pait: „Baiklah, sekarang Moehara Kamankah dihoeloe atawa Karta Negarakah dihoeloe?" Maka sahoet Maharadja Inderamoelia: „Moehara Kaman dihoeloe soengai, nama Karta Negara dihilir soengai." Ratoe Maharadja Paitpoen termenoeng mendengar 
perkataan Maharadja Inderamoelia demikian itoe karena ia radja sama radja jang empoenja itoe permintaan. Djadi Ratoe Maharadja Pait berkata kepada Maharadja Inderamoelia: „Adapoen cadatkoe ini akoe berikan kepada kita sekalian, tetapi Maharadja Sakti tempatnja ini cadat, hingga Maharadja Inderamoelia apa-apa atoeran Maharadja Sakti, (Maharadja) Inderamoelia mesti menoeroet, karena cadatkoe ini tiada boléh doea didalam satoe soengai, tjoema jang dihoeloe menoeroet $c^{c}$ adat jang dihilir." Djadi Maharadja Inderamoelia mendengar perkataan Ratoe Maharadja Pait demikian itoe, laloe berangkat serta melajang moelang kenegerinja Moehara Kaman, tiada mendapat cadatnja negerinja itoe. Adapoen Maharadja Sakti dan Maharadja Soeltan tinggal ditanah Djawa. Maka kata Ratoe Maharadja Pait kepada Maharadja jang kedoea itoe: „Ini cadat telah akoe berikan kepada Maharadja jang kedoea, tetapi akoe hendak mintas tolong poelas kepada Maharadja Sakti dan kepada Maharadja Soeltan djoea." Sahoet Maharadja Sakti : „Apakah hendak diperintahkan oléh Ratoe Maharadja Pait?” Maka kata Ratoe Maharadja Pait: „Akoe minta' tolong lepikan moréng dimoekakoe." 66) Djadi Maharadja Sakti termenoeng mendengar perkataannja Ratoe Maharadja Pait demikian itoe. Kata Maharadja Sakti : „Apakah sebabnja?” Sahoet Ratoe Maharadja Pait: „Ajahkoe Radén Djoko Toendoeran 67) mati diboenoeh oléh Tioeng Mendoro, 68) hingga akoe haraplah kepada Maharadja jang kedoea tolong boenoehkan akoe Tioeng Mendoro, djangan tiada-tiada." Sehingga Maharadja Sakti toendoek tengadah mésam-mésam moekanja, serta katanja kepada Maharadja Soeltan: „Apalah pikiran?” Sahoet Maharadja Soeltan: „Mana-mana sahadja kehendak kakanda, adinda ini mengiring sahadja apa-apa jang patoet kepada kakanda." Maka kata Maharadja Sakti kepada Maharadja Soeltan: „Itoe perintah Ratoe Maharadja Pait kita djoendjoeng sahadja, karena soedah terlandjoer pekerdjaan kita memintas cadat kepada Ratoe Maharadja Pait." Setelah itoe haripoen malam, kira-kira waktoe tengah malam Maharadja jang kedoea itoe menimboen wédjén dan mengamboer beras, haripoen siang Maharadja jang kedoea itoepoen pergilah mendapatkan Tioeng Mendoro serta ber(per)anglah didjaoeh-djaoeh dahoeloe. Setelah sampai tiga hari Tioeng Mendoro tiada akan mati, Maharadja Saktipoen laloe mengampiri, serta dekat kepada Tioeng Mendoro katanja: „Datang dimana?” Sahoet Maharadja Sakti : „Akoe ini datang ditanah Koetai sebelah timoer.” Katanja Tioeng Mendoro: „Akan ini antéro ditanah barat tiadalah bertemoe lawan boléh 68a) Maharadja tahoe.” Kata Maharadja Sakti : „Baiklah,” sehingga berperanglah antara orang kedoea itoe. Tiba-tiba terkenalah 
Tioeng Mendoro tikam Maharadja Sakti, laloe mati. Djadi Maharadja jang kedoea itoe pergi mengadap Ratoe Maharadja Pait. Setelah datang katanja Maharadja Sakti kepada Ratoe Maharadja Pait: „Adapoen perintah sampoen dikerdjakan apa jang terseboet, sehingga harap [a]lah beriboe-riboe mohonkan cadat sigera, karena hendak moelang ketanah Koetai dengan sigera.” Sahoet Ratoe Maharadja Pait: „Baiklah,” serta diberi soerat Oendang-oendang Beradja Nanti dan Oendang-oendang Pandji Salatin.69) Maka kata Ratoe Maharadja Pait: „Adapoen ini Oendang-oendang Beradja Nanti, mana-mana anak tjoetjoe Maharadja Sakti toeroen-temoeroen djenang-berdjenang, mana-mana jang djadi menteri, itoelah jang memakainja serta melakoekan apa jang terseboet didalam ini soerat Oendang(-oendang) Beradja Nanti. Adapoen Oendang-oendang Pandji Salatin ini, mana-mana anak tjoetjoe Maharadja Soeltan djadi soeltan, itoelah menaroehnja toeroen-temoeroen djenang-berdjenang." Maka katanja Ratoe Maharadja Pait kepada Maharadja Sakti : „Adapoen jang djadi soeltan itoe apa-apa pekerdjaan-

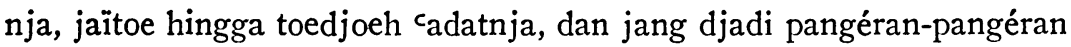
jaïtoe lima cadatnja, adapoen menteri-menteri jang toeroenan Maharadja Sakti jaïtoe lima djoea cadatnja." 70) Setelah itoe Maharadja jang kedoea itoepoen laloe berangkat moelang, serta itoe lawang sekéténg 71) dipintasnja oléh Maharadja Sakti kepada Maharadja Pait, maka sahoet Maharadja Pait: „Ambil sadja,” laloe diambilnja itoe lawang sekéténg, serta ditebakkannja 72) oléh Maharadja Sakti serta katanja: „Djanganlah awas djatoeh djikalau lain digoenoeng Djaitan Lajar." Maka berangkatlah Maharadja jang kedoea itoe ketanah Koetai goenoeng Djaitan Lajar namanja. Hingga hari-harilah Maharadja jang kedoea itoe bersoeka-soeka serta dengan kebesarannja. Adapoen Maharadja Soeradiwangsa pergi ketanah Pasir mendjadi radja ditanah Pasir. Adapoen Maharadja Inderawangsa pergi ketanah Berau mendjadi radja ditanah Berau. Adapoen Maharadja Darmawangsa pergi ketanah Boeloengan mendjadi radja ditanah Boeloengan. Djadi Maharadja jang tiga itoe tiada tinggal ditanah Koetai, tjoema anaknja sadja jang ada tinggal ditanah Koetai. Adapoen Maharadja Soeltan dan Maharadja Sakti tetaplah itoe Maharadja jang kedoea itoe ditanah Koetai Karta Negara nama negerinja. 73)

Sehingga berapakah lamanja, maka datanglah perintah oegama Islam sjahadat doea kalimah dibawa oléh Toean Bertoenggangkan Ikan Parangan kepada Maharadja Sakti dan kepada Maharadja Soeltan. Katanja Toean Bertoenggangkan Ikan Parangan kepada Maharadja Sakti dan kepada Maharadja Soeltan: „Ikoetlah sjahadat doea kalimah 
ini : asjhadoe allā 74) ilāha illallāhoe wa asjhadoe anna Moeḥammad(an) rasōeloellāh." Hingga termenoenglah Maharadja jang kedoea itoe mendengar itoe sjahadat, serta Maharadja jang kedoea itoe mintas tanggoeh „karena lagi hendak moefakat antara kami kedoea ini." Maka sahoet Toean Toenggang Parangan: „Baiklah.” Maka moefakatlah antara Maharadja jang kedoea itoe, maka kata Maharadja Soeltan: „Akoe tiada hendak mengikoet itoe oegama." Maka kata Maharadja Sakti: „Baiklah diikoet, djangan dilawan itoe perintah, karena tiada terlawan didalam pertapaankoe." Maka kata Maharadja Soeltan: „Djangan dahoeloe diikoet, akoe lagi hendak bertjoba dengan Toean Toenggang Ikan Parangan: terbangkanlah mahkotakoe dengan kasoetnja keatas oedara, djikalau soedah djatoeh keboemi, maka lihatlah: djikalau kasoetnja keatas, baharoelah akoe hendak mengikoet, djikalau mahkota diatas, tiadalah akoe hendak mengikoet itoe oegamanja.” Katanja Maharadja Sakti: „Tentoelah Maharadja Soeltan djadi kalah djikalau begitoe perboeatan." Maka jaitoe panaslah hati Maharadja Soeltan mendengar perkataan Maharadja Sakti demikian itoe, serta dipanggil itoe Toean Toenggang Ikan Parangan. Katanja Maharadja Soeltan: „Terbangkanlah mahkotakoe dengan kasoet toean keatas oedara. Djikalau soedah djatoeh keboemi, maka lihatlah: djikalau mahkotakoe diatas, kasoet toean dibawah, tiadalah akoe hendak mengikoet oegama toean, dan djikalau kasoet toean keatas, mahkotakoe dibawah, baharoelah akoe hendak mengikoet oegama toean." Katanja itoe toean: „Baiklah.” Laloe diterbangkanlah barang jang kedoea itoe keatas oedara. Setelah djatoeh barang jang kedoea itoe keboemi, maka dilihat oléh toean dan Maharadja Soeltan jaitoe mahkota dibawah, kasoet keatas. Maka kata toean itoe: „Ikoetlah oegamakoe itoe." Sahoet Maharadja Soeltan: „Beloem akoe hendak, lagi sekali, akoe berpoekoeng, 75) toean mentjari. Djikalau dapat, baharoelah akoe mengikoet, djikalau tiada dapat, tiadalah akoe hendak mengikoet oegama toean." Maka kata toean itoe: „Baiklah.” Maharadja Soeltanpoen laloe pergi berpoekoeng 75) kemasjrik da(n) kemagrib, (ke)daksina dan kepaksina, jaitoe toean mentjari dengan ratib tesbih hingga dapatlah Maharadja Soeltan. Maka kata Maharadja Soeltan: „Toean poela berpoekoeng, akoe poela mentjari.” Sahoet toean: „Baiklah.” Jaïtoe toean hingga berpoekoeng didalam diri Maharadja Soeltan, 76) jaitoe mentjarilah Maharadja Soeltan keliling calam Koetai, tiadalah bertemoe. Katanja Maharadja Soeltan: „Dimanakah toean berpoekoeng ?” Maka menjahoetlah toean: „Didalam diri Maharadja Soeltan," serta katanja Toean Bertoenggangkan Ikan Parangan: „Ikoetlah ini oegamakoe." Serta Maharadja jang kedoea 
itoelah mengikoet oegama sjahadat doea kalimah. Setelah sempoernalah oegama Islam kepada Maharadja jang kedoea itoe, dan adapoen Maharadja Soeltan beranakkan Adji di Langgar, adapoen Maharadja Sakti beranakkan Adji Pati Madjakesoema, d.s.t.

\section{Aantekeningen.}

1) Zie Sal. 183/26. - 2) Oeringin Gelanggang, waarschijnlijk een legendarische, geen werkelijke plaatsnaam; oeringin = waringin. 3) (h)oedjan langat, koet. regen met zonneschijn, mal. hoedjan panas. - 4) Sal. 118/30. - 5) ring-ring (réng-réng?), een geluidsnabootsing, rinkelend? Dat de gouden bol aan een ketting wordt neergelaten, wat hier blijkbaar de bedoeling is, wordt in de Sal. niet vermeld. - 6) Zie Sal. 134/16. - 7) djangkat, koet. hemel = kajangan, waarschijnlijk uit het Toendjoengs. - 8) gandék, het jav. gandèk, bode van een vorst? - 9) Zie Sal. 118/3. - 10) tapas, koet. zeer zwaar, stromend (v. d. regen). - 11) minangan, koet. = peminangan; vgl. dezelfde afkorting: met verzwakking van de eerste vocaal, in sd. menangan, ,,an uncovered brass box with four wheels, used to hold the chewing instruments". 12) landjoeng, koet. soort van draagmand, bdj. id., vgl. md.-mal. 13) koelit, koet. grote ronde rijstbewaarplaats van boomschors. 14) talihan, wanspelling voor telian. - 15) Zie Sal. 189/20. - 16) Zie Sal. 123/33. - 17) Spelling van het hs. radaskoe; redas, koet. kleine opborrelende luchtbellen. - 18) nimboen asap, koet. een soort van reukwortel branden. - 19) ridik, koet. ongeveer hetzelfde als redas (17). - 20) kentjang, koet. heel veel. - 21) timbangan, koet. ter hoogte van, mal. tentang(an), bdj. pintangan. - 22) Zie Sal. 125/3. - 23) Zie Sal. 126/6. - 24-25) Zie Sal. 154/19. - 26) Zie Sal. 154/23. 27) Zie Sal. 154/21. - 28) Zie Sal. 154/23. - 29) Zie Sal. 154/23. -30) mendjantan, koet. treden (haan) = mal. mendjantani. - 31) Zie Sal. 158/12. - 32) Zie Sal. 196/20. - 33) Zie Sal. 159/15. - 34) nebak, koet. werpen $=$ mal. melémpar, bdj. manawak; vgl. 72 ditcbakkannja. - 35) moehara, bandjariserende spelling voor moeara; $m$. lawang, koet. bdj. deuropening. - 36-37) Zie Sal. 137/29. - 38) pengoegoe, koet. hoeder, mal. gembala; ngoegoe, (dieren) verzorgen, houden. - 39) Zie Sal. 137/24. - 40) Zie Sal. 174/13. - 41) poles, koet. blijkbaar, zeker, dus; gebruikt als wat eerst niet duidelijk was later blijkt. - 42) Zie Sal. 166/15. - 43) tjampoer-tjemah, koet. omgaan, mal. tjampoer-gaoel. - 44) Zie Sal. 167/31. - 44a) Zie Sal. 
196/5. - 45) Bengalong, t.r. Bengalon, zoals verderop ook gespeld wordt. - 46) Mengkaning, t.r. Mengkanjing. - 47) In de Sal. springt de bamboe op de vindplaats open, terwijl Meragoei en zijn vrouw er de wacht bij houden. - 48) Zie Sal. 196/20. - 49) Zie Sal. 172/5. - 50) naik, bedoeld is blijkbaar naik dara, koet. volwassen worden, bdj. id. - 51) toelas di, koet. vanaf, bdj. toelak di id. - 52) Zie Sal. 165/27. - 53) Zie Sal. 166/15. - 54) bidas, koet. een omvangsmaat, aanduidend wat men tussen twee handen kan omvatten, als men de toppen der duimen en middelvingers tegen elkaar houdt, bdj. id. 55) Zie Sal. 183/30. - 56) Zie Sal. 184/13. - 57) In de Sal. heten zij resp. Radja Poeteri en Déwa Poeteri. - 58) sida, koet. pron. pers. 3e pers. pl. = mal. meréka itoe, sd. id., vgl. Toba nasida enz. 59) Maharadja Pait, een verbastering van (Maha)radja Madjapait; vergelijk den "Radja Pait” der Ngadjoe's (Hardeland sv. radja). 60) terdjali, bekende verbastering van arab. tadjalli, vgl. Wilk. sv. en Klinkert onder tadjalli; koet. uitspraak is terdjeli. - 61) dikidjapinja; kidjap komt naast kedjap en kidjip voor, vgl. Klinkert sv. kidjip en min. kidjap en kidjos. Voor de vorm vgl. Sal. 197/20 v. koekedjapi. - 62) Zie Sal. 196/20. - 63) tjindera, koet. = mal. tjendera, bdj. id. - 64) astinggil, in de Sal. steeds setinggil. - 65) Zie Sal. 143/17. - 66) lepikan moréng dimoekakoe, koet. i.q. mal. hapoeskan arang dimoekakoe; lepikan gaf men weer met mal. tanggal, boeang, nl. van een vuile veeg; moréng is een zwarte veeg op het gelaat, bdj. moering id., vgl. mal. tjoréng-moréng. - 67) Djoko Toendoeran, jav. Djåka Tandoeran. - 68) Tioeng Mendoro, jav. Sioeng (snd. Tjioeng) Wanårå. - 68a) Zie Sal. 237/25. - 69) Zie inleiding, bl. 30 70) Voor gewone menteri's is het adatgetal namelijk slechts drie, vgl. Oend. B.N. fasal 42: djika mentjoeri benda radja: esa moelang toedjoeh, djika anak tjoetjoe radja atau saudaranja radja: esa moelang lima, djika harta menteri: esa moelang tiga, enz. - 71) Zie Sal. 223/29. - 72) Zie 34. - 73) Dit verhaal van het vertrek der drie middelste Maharadja's is niet in overeenstemming met de gewone overlevering. Volgens de Salasilah is het juist Maharadja Sakti, die het land verlaat. en wel om naar Pasir te gaan en daar te huwen met een dochter van den vorst van dat land. - 74) Naar de fonetische schrijfwijze van het handschrift. - 75) berpoekoeng, koet. zich verbergen, zich verstoppen. - 76) Vergelijk een dergelijke verstopwedstrijd, waarbij iemand zich in de buik van zijn tegenstander verbergt, in de Kroniek van Bandjarmasin (Cense, diss. bl. 82). 


\section{K L A P P E R}

In deze lijst zijn, zoveel mogelijk gerangschikt naar de grondwoorden, de in de commentaar, de inleiding (,inl.”) en de aantekeningen der bijlage („KV”) behandelde woorden opgenomen. Voorzover zij niet in de tekst der Salasilah volgens hs. $\mathrm{N}$ voorkomen zijn zij cursief gedrukt, dus ook de ter vergelijking uit andere talen aangehaalde woorden. Gewone mal. woorden, die in de commentaar soms ter vertaling of vergelijking van een dialectisch woord voorkomen, zijn niet opgenomen.

adalah $120 / 21$

adat; meng-i, ma-i 238/8

adi $203 / 2$

adja; pang- 204/20

adjar; peng- 204/20

adji $130 / 28$

agoeng $155 / 11$; seagoenging $204 / 8$

air toedjoeh soengai $136 / 4$

air toeli $229 / 16$

a jam $121 / 10$

ajau ; meng- $130 / 9$

ajoen, ajoen papan, ajoenan $137 / 24$

akadang $119 / 20$

ala $126 / 16$

alak, meng-, di- 126/16

alap; meng-i 195/9

alat; ke-an 144/19

alis; meng- kening, ng- 221/30

amaténi 195/34

ambah; ang- 160/27

amban; ma- 130/31

amit $154 / 4$

ampar (tilam -) 132/3

ampir $138 / 7$

ampoean $139 / 26$

ampoen 139/26

anak bini (isteri) orang 186/31

anak tjoetjoe 119/24

anas 206/14

anda $123 / 22$

andar; di-kannja 123/22

andika $141 / 28$

angalar koembang sari $206 / 23$ angarangin $132 / 8$

angan $^{2}$, angen 2 , 196/1

anggadoeh $215 / 15$

anggo; meng- $131 / 18$, anggo 2

anggon $^{2} 215 / 20$

$[215 / 20$

anggrék (anggerik) medjati

(medjeti) 136/31

anggrék menoer 206/20

angkit, meng- $151 / 9$

angin bertjampoeh 196/18

angrarangin $132 / 8$

anis $206 / 14$

anisis 206/14

anjoekani $215 / 20$

anoem, anom 200/12

antakesoema 136/27

antasari $137 / 1$

antok?; meng-kan 132/27

arak; ma- 158/18

arak adas, - das 206/14

arangin; (m)angarangin 132/28

aroe; di- $128 / 7$

arwah; ba-kan $257 / 28$

asap; menimboen - KV 18

asoeh ; meng-, -an 119/24

asoekoe toenggal 145/11

asoh; ng-, -an 119/24

astinggil $\mathrm{KV} 64$

atas; ke-nja $244 / 8$

atawa $145 / 19$

atoer, meng-, -i, -kan $132 / 3$

atri $133 / 1$

awak 119/19 
basatoeran $165 / 32$

babahan nawa-sanga 160/27

babahan songo $160 / 27$

baboe(anda) 118/3

baboet 131/19

badjoe teratai $226 / 4$

bai $127 / 32$

baik, -nja 139/27

baik-baik 249/27

baja ; be-, dipe-kan 128/18

bajang-bajang Allah tacala 241/11

bajoe pengibaran 196/5

balai boeroeng $133 / 6$

” kambang (kembang) 225/30

, mandargili 131/31

, matjan $133 / 6$

„ memoeloe $133 / 6$

, mendjangan 133/6

" moemoela $133 / 6$

, teraté $133 / 6$

balaman $241 / 20$

balé kambang 225/30

balik 120/30; ber-, mem-kan 157/8

balō 128/22

bandjar; ba-an $211 / 9$

bandjaran sari $211 / 32$

bang bintoeloe adji $131 / 7$

banjoet $179 / 29$

banoea $133 / 26$

bantala $131 / 9$

bantan $136 / 6$

banténg menamang $128 / 3$

bantjar; di- 132/11

bantolo $131 / 9$

bapas $122 / 4$

bapang $136 / 29$

bara-bara $140 / 4$

barang; awak -2kan 173/27

barih $165 / 17$

baroeis $121 / 19$

baroet 121/19

basa; di-inja, mem-kan, ambasani, ambasakaké 156/31

basah 125/11

batak; be- $129 / 9$

batang malang $248 / 25$

batis $149 / 9$

batoeran $165 / 32$ bawah; ke-nja, tanah - 244/8

bawas $120 / 1$

bedil benaga $233 / 9$

bekal; be-, pem- 231/27

bekel, pem-231/27

belabar; di-i 128/30

beladau; di-nja $154 / 23$

belah $175 / 16$; berse-an tempat

beleman $241 / 20$

belian $121 / 20$

$[141 / 17$

belos; pem-an 207/17

belolang 139/15

bemboeding 123/33

benaloe $136 / 32$

benia menerdjoeni poeloet $158 / 13$

benoea $133 / 26$; sepoeloeh -, tiga belas - $134 / 10$

bentang; mem- 125/13

bentjar; di-132/11

beradja $252 / 19$

berata I $118 / 19$

berata II ; be- $186 / 6$

berengos $160 / 30$

betis $145 / 9$

bidas $\mathrm{KV} 54$

bidja koening 120/18

bidji's pelir $252 / 30$

bigi (bigis) pelér, 252/30

bilalai $126 / 7$

bilang; di-kan 154/12; - boelannja

binata-rana $198 / 6$

banatorono $198 / 26$

bini, -2, ba-, bi- 122/1

bintala $131 / 9$

bintiëng 122/16

bintir 132/10

bintoeloe $131 / 7$

bisa-bisa 249/17

biti $179 / 30$

bobot; batoe - $250 / 21$

boeah gajam $140 / 1$

boeat; di-nja $122 / 8$

boedak $^{2} 122 / 18$

boedjak $145 / 7$

boedjang landjoean 158/9

boedjang ; pem-an (poespa -), pe-an

(geta -, balai -), per-an 245/7

boejah $136 / 26$ 
boejoet $203 / 7$

boeka ; pem-(an) moeloet 165/1

boelang; mem- 146/24

boemboen; di-i 128/30

boemi astana $133 / 17$

boenda $118 / 3$

boenga (ri)tompong 174/13

boenji; ber- 125/19

boentala $131 / 9$

boerit kang 144/28, 160/15

bokor bewajang 229/17

bokor sinalangan (geloeng -)

bokor tembaga 141/33

boléh $237 / 25$

boma menerkam 131/13

boma-widjaja 131/13

boréh; be-, ber-, mem-i 160/8

brata 118/19

chandjar 130/1

dadéh 139/29

dahar; di-nja $234 / 30$

daja; be(r)pe- 162/15

dajang $125 / 22$

dalam; di- hati $133 / 18$

dalam; pe-an, ka-an 144/7

damhati $133 / 18$

damini $128 / 30$

damintoe $128 / 30$

dandang goela $216 / 18$

dangsanak, dansanas 228/13

daoeloe $126 / 22$

daoeng; ber-, pen-an 132/5

daroewoeh 216/19

das (arak -) 206/13

dedak; se- $165 / 28$

dédés dédong 257/21

demi $128 / 30$

demini $128 / 30$

demintoe, demitoe $128 / 30$

démpok; men- $223 / 6$

dèndèng agé 206/11

déndéng anggi 206/11

dengan I 123/1

gepoek 206/11

dengan II 154/13

dengar; si-2i $125 / 24$, sepen-an

dengsanas $228 / 13$ derab ; ber- $193 / 10$

derai ; ber- $193 / 10$

désa $143 / 17$

déwa $121 / 20$

di $120 / 10$

diakoe $122 / 21$

diawak 122/21

didia $122 / 21$

dikit lagi $138 / 7$

dinihari moeda 124/15

dipatoean (dipertoean) 145/33

diri ; men-kan radja $186 / 20$

[206/21 djaba 225/15

djabang baji $119 / 12$

djaga koctai $131 / 23$

djagal; pe-an $207 / 17$

djajang (si-) 131/14

, katon 131/14

" sari $131 / 14$

, seteroe $131 / 14$

djajéng katon (si-) 131/14

djala I 165/9

djala II, -2, dje- 118/34

djalan 209/16

djamah; dje-an, -an, -2an 228/9

djamban 165/9

djampi; di-nja 167/14

djangan; men-i 255/7

djangkat $\mathrm{KV} 7$

djantan; men- KV 30

djanti $207 / 22$

djaoen 196/17

djaoetn 196/17

djarat; man- $165 / 8$

djat $222 / 8$

djawang ari (di-) 196/9

djelépok; men- 160/27

djemenang, zie djoemenang

djenak 154/17

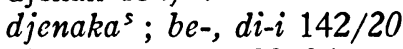

djenang ; ber-, 183/26;

men-kan 120/6

djerang ; ber-, men-(kan) 121/34

djenéwar, djenèwer, djenéwér

djenoe $137 / 1$

djerat, pen-, $n-165 / 8$

djeriangau $128 / 22$

[206/14

[245/2 djerat; pen-, $n-165 / 8$ 


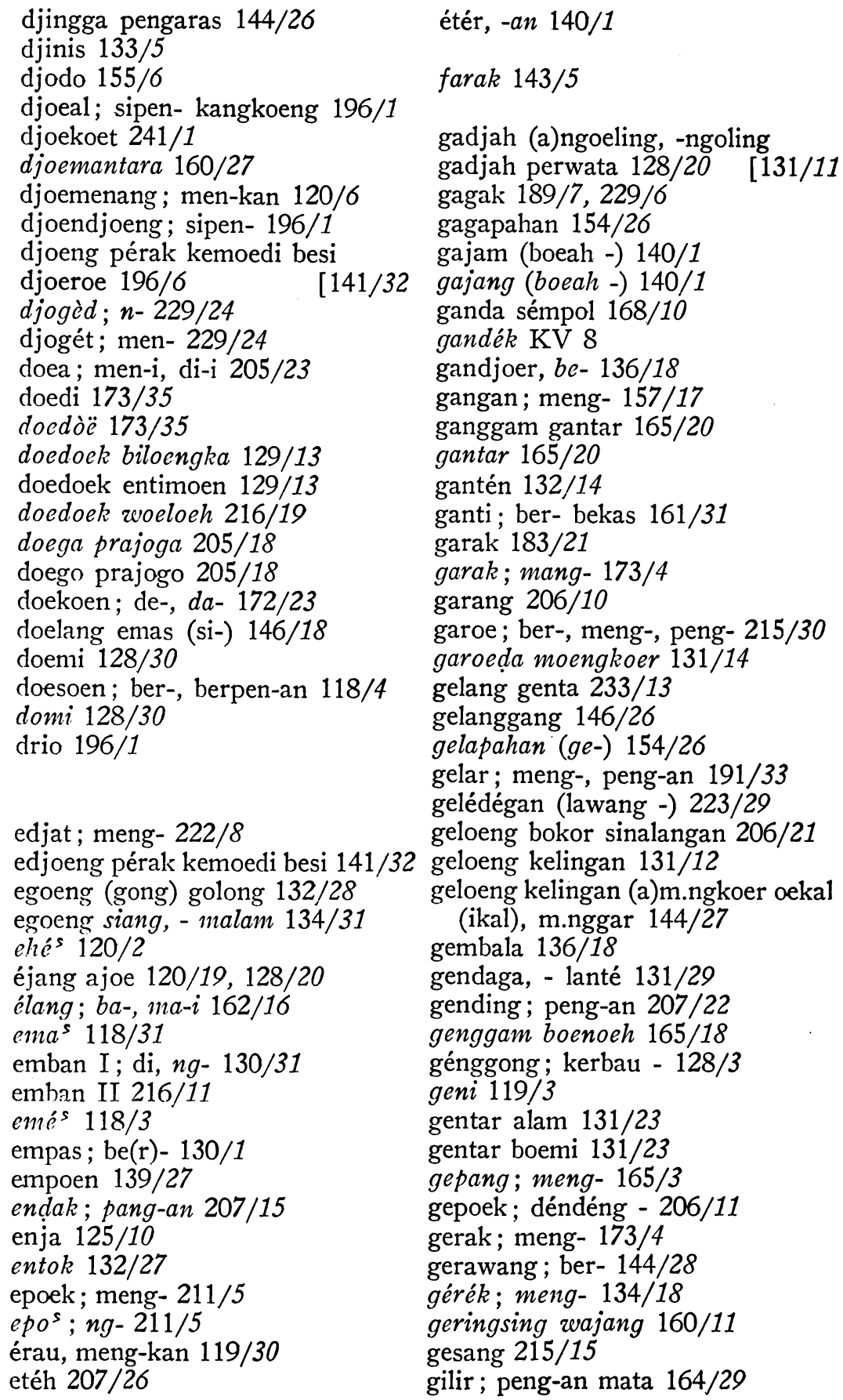

étér, -an 140/1

farak $143 / 5$

gadjah (a)ngoeling, -ngoling gadjah perwata $128 / 20$

gagak 189/7, 229/6

gagapahan 154/26

gajam (boeah -) 140/1

gajang (boeah -) 140/1

ganda sémpol 168/10

gandék KV 8

gandjoer, be-136/18

gangan; meng- $157 / 17$

ganggam gantar $165 / 20$

gantar $165 / 20$

gantén $132 / 14$

ganti; ber- bekas $161 / 31$

garak $183 / 21$

garak; mang- $173 / 4$

garang 206/10

garoe ; ber-, meng-, peng- $215 / 30$

garoeda moengkoer 131/14

gelang genta $233 / 13$

gelanggang $146 / 26$

gelapahan (ge-) 154/26

gelar; meng-, peng-an 191/33

gelédégan (lawang -) 223/29

geloeng bokor sinalangan $206 / 21$

geloeng kelingan 131/12

geloeng kelingan (a)m.ngkoer oekal

(ikal), m.nggar 144/27

gembala $136 / 18$

gendaga, - lanté 131/29

gending; peng-an 207/22

genggam boenoeh 165/18

génggong; kerbau - 128/3

geni $119 / 3$

gentar alam 131/23

gentar boemi $131 / 23$

gepang; meng- 165/3

gepoek; déndéng - 206/11

gerak; meng- 173/4

gerawang ; ber- $144 / 28$

gérék; meng-134/18

geringsing wajang 160/11

gesang $215 / 15$

gilir; peng-an mata 164/29 
gimbal 128/2

glèḍègan (lawang -) 223/29

gobang, zie goebang

goebah; ge-an, goe-an 160/20

goebang 126/14

goegoer; -i 165/17

goeling, ge- 216/16

goeling ; panggang - 206/10

goeloeng, zie golong

goerda moengkoer 131/14

goerindjam 132/12

goeringsing (wajang) 160/11

gong golong $132 / 28$

gonoroso $215 / 20$

goro $^{\text {; }}$ be- $119 / 30$

grah $123 / 8$

habis; ke-2an soempah $189 / 20$ meng-i 242/33

habis bac da $263 / 3$

hadap; peng(h)adapan $256 / 5$

hajam 121/10

halambak $144 / 29$

halang oeloe 119/14

hali $208 / 30$

hampir $138 / 7$

hangsa $128 / 2$

hanjoet; ber- $179 / 29$

harap di.... 209/34

haridjaja $142 / 5$

haroe, zie aroe

hati ; didalam - 133/18

hilang $162 / 16$

hing $196 / 13$

hirang 124/4

hoedjoeng, pe-an 120/21

hoema; ba- 121/16

iang; ber-2 120/19

iang-io $128 / 20$

ibar; peng-an 196/5

iber 196/5

idjik; meng- 222/21

inai; ber- $134 / 34$

indoe(k) $123 / 33$

ing 196/13

inggihpoen 137/29

inja $121 / 20$ ipoen $137 / 29$

irau, iraw 119/30

iring; ber-2 128/17

isjarat $217 / 1$

jang $125 / 22$

jang-io, jang-jò 128/20

kadang 119/20

kadang warga 119/20

kadaton 160/19

kadedepan 154/19

kadjang sirah 119/14

kadjineman 207/14

kah 141/9

kah $137 / 29$

kaïna 202/20

kais; ber-(2)an $158 / 3$

kakak perba (poerba) djaja 147/11

kalabat 140/2

kalakian $118 / 3$

kalalepon $207 / 29$

kala-moejang 144/29

kala-moenjeng 144/29

kalang; ber-2 173/20

kalang hoeloe $119 / 14$

kalang sirah 119/14

kalawet $140 / 2$

kaloeng bantolo $131 / 9$

kaloeng basing 233/14

kamarian $134 / 8$

kambala 136/18

kambar-kambar 196/16

kambit; sesaté - 206/12

kamoedi reasi 141/32

kampoeh 131/7

kampoeng (jang) empat, empat $240 / 23$ v.

kampoeng kawal 189/12

kanak, ke-, - 2 125/23

kandjar, ber-, meng-kan 130/1

kandjeng romo $215 / 10$

kangdjeng rama $215 / 10$

kanigara $210 / 10$

kantjing geloeng 160/15

kaoel ; meng-kan selamat $233 / 18$

kaoela $141 / 28$; meng- $232 / 3$

kaoelo noen $229 / 10$ 
kapoehoet $252 / 33$

karang 197/27

karang, - mendoengkoel 126/6

karangan $183 / 30$

karang ng.njap 211/9

karangoeloe 119/14

karasmin 245/9

karaton 160/19

karing tilam $137 / 2$

karioek (?); meng- 134/18

karoean; ber- $180 / 2$

kasoer baboet 131/19

kazva 129/20

kawal $189 / 12$

kawarea 129/20

kawin; meng-i 215/20

kazvoela, $n g-232 / 3$

kebandan lepas 168/21

kedaton 160/19

kedèp; ng-i 197/20

kedepan 154/19

kedjap; koe-i 197/20

kelat bahoe $136 / 28$

kelelepon 207/29

kelembak 144/29

keléntangan 134/9

kelepon $207 / 29$

keletak; meng- 252/29

kelian 165/4

keliawat $140 / 2$

keliki $132 / 32$

kelingan; geloeng - 131/12

kelngoeroe 119/14

keloepoer; ber-, meng- 154/20

kelok sepit $172 / 28$

kelopak oedang 136/28

kélor; ber- $124 / 29$

kembali $185 / 25$

kemban lepas 168/21

kembang baroe; meng- 137/2

kemerian $134 / 8$

kemit; ber-, meng-(i) 198/16

kemoedi besi $141 / 32$

kempoean $156 / 1$

kéna 202/20

kenaka $131 / 15$

kendaga 131/19

kendi pertola (pratola) 228/5 kendia 202/20

kenit 206/14

kenjapoeri $210 / 21$

kenoko $131 / 15$

kentjang $\mathrm{KV} 20$

kepada $118 / 19$

kepai; meng-kan 124/7

kepeda', kepedak 207/10

kepil; meng-kan 124/7

keradjat madjat $130 / 27$

kerah; meng-kan 123/8

kerangan $183 / 20$

keraton $160 / 19$

kerbau génggong $128 / 3$

keresmén $245 / 9$

kerétjot 196/7

kering tilam $137 / 2$

kero $149 / 20$

kerojos'; meng- 134/18

kerongo $187 / 21$

kertas Arab inl. § 1.

kesoema 119/21

ketaran $^{2}$ 196/10

ketari $125 / 30$

keter $196 / 10$

ketikai, - lepas 229/17

ki, kiai $128 / 24$

kiau; ber-, $n g-227 / 2$

kidjap; di-i KV 61

kikip; meng-kan 125/7

kilat ba(h)oe 136/28

ki mas $246 / 17$

kinjar; ber-2 224/12

kira; meng-2 kan 130/6

kirim ; meng-kan, ber-kan, $b a$ -

kirin ; ba- 167/11

kita $231 / 33$

kobosan $140 / 10$

koeasa, peng-an $145 / 15$

koeawa $129 / 20$

koejoek, zie kojos

koela kadang 119/20

koelan $137 / 29$

koeliling $121 / 36$

koelip; ke-an (?) 228/4

koelit $\mathrm{KV} 13$

koembala $136 / 18$

koempai $166 / 4$ 
koempoel ; di-kan kepada 235/18

koendjang $231 / 16$

koentoel $229 / 5$

koeroeng-koeroeng 229/19

koesoema, zie kesoema

koetika 120/23

koetjah-meng-kan 140/15

koetjoe; ke- (?) $228 / 4$

kojos $172 / 34$

kola $141 / 28$

kompas; be - $130 / 1$

kontjang ; ber- $154 / 26$

kota tjondong $132 / 7$

kotjor, ke-228/4

krojok, ng- 134/18

laboeh; me- $136 / 6$; ba- 179/29

ladau; di-kannja. 154/21

ladi, ngladèni 209/10

lading 165/12

ladjoe $126 / 18$

ladri $209 / 10$

lain $182 / 5$; me-(i) $202 / 22$

lajang; angin pe-an 196/5

lajin $182 / 5$

laki, -2 , la- $122 / 1$

lakoe $132 / 11$

lakon, le- $160 / 12$

laloe; se- $224 / 14$

lama; se- $128 / 23$

landjoean 158/9

landjoeng $\mathrm{KV} 12$

landjon $158 / 9$

langat $\mathrm{KV} 3$

langgoeai $150 / 13$

langgoeng $129 / 8$

langgway 150/13

langkap, se- $132 / 18$

lanté $131 / 19$

lantjang $165 / 13$

laoet, me-i $125 / 28$

larah; ber-2an 151/28

lara-pangkon 131/21

larih; ber-2an 151/28

latar, la- 196/27

lawang $138 / 1$

lawas $132 / 9$

leboe, leboeh 232/31 léko, lees overal likoe

léman $131 / 29$

lemboe $128 / 1$

lemboe soeana $126 / 6$

lemiding $123 / 33$

lempong, - soeit $123 / 32$

lenga ; ber- $153 / 19$

lenga bébér 140/1

léngah; me- 196/22

lénggang; me- (papan) 132/32

lenggoeai, lengoeai 150/13

lentoet $154 / 19$

lepas; -2, pe-an 229/17

lepas koeroeng-koeroeng 229/19

lepi; -kan KV 66

liman 131/29

likoe; padoeka - 207/5

limar angsana $136 / 11$

limbah bada $263 / 3$

limboer; be-131/4

limpah $239 / 15$

limpas; me-i 174/21

lindoeng doedoek, (se-) 233/12

lingau $165 / 18$

linggih $206 / 26$

lingoe $165 / 18$

liskar $218 / 7$

loah $134 / 13$

loeloe $165 / 32$

loeloeh; be- 229/17

loemadjang (si-) 132/10

loemakoe (si-) 132/10

loemoes $118 / 33$

loempat $149 / 20$

loenggoeai $150 / 13$

lomos $118 / 33$

lontar penjangkahan, - pertenoengan $154 / 6,189 / 20$

loros; me-kan 150/13

lunggreai $150 / 13$

madah, ber- $157 / 13$

madoe kasirat $207 / 28$

madoe mongso (- mangsa) $207 / 28$

madoe sirat $207 / 28$

madya-gantang $196 / 10$

magarsari $134 / 10,207 / 20$

magersari $207 / 20$ 
magoelinga tata 209/22

maha, -2, pe-2 119/30

mahajanti 205/31

makan sirih; doea - 151/9

mas inang $118 / 3$

macmoer $179 / 15$

$\mathrm{ma}^{\mathrm{s}}$ soed, mac soed 198/26

malap boemi 209/23

maligai $136 / 23$

mama(nda) $118 / 31$

mandakaki 160/20

mandargili 131/31

mandau 256/19

mandi2 197/1

mandis $120 / 2$

mandja 162/2

mandragini 131/31

manoek, manos $166 / 26$

maoek, maos 166/26

maras $^{s} 158 / 18$

mardjo gantang 196/10

martabat $187 / 29$

masak; ba- 121/34

matoer $132 / 3$

matoer; padoeka - 207/5

matowa 264/14

mandic 209/14

mawidji 201/1

méga berangkat 206/23

méga malang 196/30

mela $171 / 28$

memaroeangi (?) $173 / 10$

menamang ; banténg - $128 / 3$

menang; se-2nja $152 / 12$

menangan $\mathrm{KV} 11$

mendau 256/19

mendjangan $130 / 20$

mengadak 205/20

mengapang $165 / 3$

menggoelinga tata 209/22

merak mengigal 144/27

meranggi 207/21

merian 134/8

meroen $128 / 25$

mesaoerat, $144 / 4$, zie moesjawarat

metoea 264/14

minangan $\mathrm{KV} 11$

mindargili $131 / 31$ mini $128 / 30$

miris $233 / 27$

misit $233 / 27$

mitoe $128 / 30$

moeara lawang KV 35

moeda ; berlakoe -, main - 167/21

mocdo; ba-, main - 167/21

moehara lawang KV 35

moeka; ber-2 166/26

moeksa $120 / 10$

moelang 126/18

moelia; ber-kan 205/2

moempoeng 143/5

moering KV 66

moesazvarataké 193/8

moesjawarat(kan) 193/8

moesna $169 / 6$

moestacib 164/25

molo $152 / 33$

moréng KV 66

morong, me- 165/19

mranggi $207 / 21$

naga $122 / 16$, be- $233 / 9$

naga kapoelir 136/29

nagang ; tadjau - 165/21

naik dara KV 50

ndis $120 / 2$

negeri $133 / 26$, sepoeloeh -, sebelas

-, doea poeloeh tiga - 134/10

ném 161/11

néné' nda $221 / 14$

nerojong $227 / 22$

ngabé, ngabéi $128 / 24$

ngadang; me- $176 / 33$

ngadeg $205 / 20$

ngalang 176/33

ngarang, me-gantar 176/33

ngèdjèg 222/21

ngebé $128 / 14$

ngentok 132/27

ngétjés 222/21

ngidjig 222/21

ngloroni $205 / 23$

niaga $207 / 15$

niam $161 / 11$

-nja $125 / 10$

s nja 125/10 
njala; di-inja $154 / 31$

noen $137 / 29$

noman, nom-noman 207/28

oeang kemit 198/16

oebat-oebat $136 / 27$

oeda negara $212 / 11$

oedjoeng; ber- 120/21

oedo nagoro (- negara, - negaro) $212 / 11$

oegoe; meng-, peng- KV 38

oelam garang asem 206/10

oelas balai, - boemi $133 / 3$

oeloen, ber-kan, dipe(r)- $181 / 3$

oeloer $158 / 13$

oema, be- $121 / 16$

oembang $225 / 17$

oembas; be- $196 / 5$

oempat $149 / 20$

oendang; -an, meng-, meng- air

oentjal $172 / 12$

oerab-oerab $131 / 4$

oerap, -2, ber-2, ber-(2)an 131/14

oeria $253 / 2$

oeringin gelanggang $\mathrm{KV} 2$

oever $237 / 24$

olah $126 / 16$

ontrokesoemo 136/27

orang 164/29

padah ; ber-, di-kannja $157 / 13$

padang orang banjak (di-) 199/25

padjang; pa-an, pem-an 245/7

padmi $213 / 20$

padoeka likoe 207/5

padoeka matoer 207/5

padoeraksa (padoerassa) 169/3

pahat dalam 196/2

pahawas $128 / 21$

pajas; -an, di-i 133/5

pajau $130 / 20$

pajoeng agoeng, - bawat; - oeboer ${ }^{2}$, - oemboel $131 / 19$

pakai 191/3 ; di-i, me-(2) 131/7 ; me-, -an (fig.) $188 / 21$

pakaian; di-i 131/7

palas; mam- 171/28

pali bagindjau 196/18 pambakal 231/27

pamit $154 / 4$

panah; ber-2an, - air 131/4

pandawa-djaja 160/11

pandawa poelang sah $160 / 11$

pandén, pe- petola $132 / 25$

pandér ; ber-( $\left.{ }^{2}\right)$, mem-(2),

mem-(2)kan $125 / 18$

pandi ; di- $131 / 1$

pandir zie pandér

paneda $i 20 / 21$

pangadeg 199/31

panganen 122/2/16

pangempon, pangempwan 156/1

pangendakan 207/15

pangkoean, pe-zie pangkon

pangkon, pe- $131 / 21$

pangsan 173/17

pantjadria $196 / 1$

pantjak soedji $132 / 7$

papak; mem-air 119/28

parak, - siang $143 / 5$

parang roesak $160 / 18$

parangan 241/1

paranjaï 206/17

parapi $121 / 31$

parek $143 / 5$

pasan $173 / 17$

patah; - mem- 123/14

patedan 207/24

pati $129 / 11$, ke-an $209 / 3$

patik $141 / 28$

patiloe 252/33

patjar ; ber-, ber- inai 134/34

patoeih toengga. 131/25

patoek 142/7

patoet; di-2kan 161/15

patos $142 / 7$

patola $132 / 25$

pawadoe 164/23

pawon $206 / 8$

pedah $157 / 13$

pedjah $215 / 15$

pekenan $225 / 2$

pelas ; di- $171 / 28$; melas tanah

pelén 225/2

$[119 / 30$

pemanggian ari, - goenoeng 196/29

pemapag, pemapak 165/28 
peminggi, - besaroe $252 / 33$

penangsat $136 / 27$

pendi, mendi(i) $131 / 1$

pendjoedjoe, be- $164 / 22$

peneda; se- $120 / 21$

pengadak 199/31

pengaras $144 / 26$

pengawinan $135 / 24$

pengempoean $156 / 1$

pengendakan 207/15

peningset $136 / 27$

pepelik 206,'23

peradja, peradje $155 / 6$

perak siang $143 / 5$

perang ketitih $211 / 9$

pergi ; pem-an 145/17

peridan; di- $131 / 32$

peridjas $132 / 32$

peri kinantan $136 / 30$

permata benoea, - negeri $133 / 26$

peroempoeng $128 / 6$

pertola ; kendi - 228/5

petedan $207 / 24$

petimban $148 / 27$

petinggi $118 / 15$

petir toenggal $131 / 25$

petoeng, petong $172 / 4$

petola, petolo $142 / 7$

petongot 229/17

pian 198/34

pias; -an, di-i 133/5

piawas $128 / 26$

piawèh 128/26

piling; di-2nja 160/29

pimpin; ber- $131 / 32$

pindjoeng, ber- $173 / 25$

pinggan memorong 165/19

, ranti (rantai) 165/24

” sangkar $165 / 22$

pinta $^{\text {s, mem- } 120 / 18}$

piskal 207/17

plasi $171 / 28$

poda $157 / 13$

poea adoe, poeadoe $264 / 23$

poedja, men-; - berata ; mem-

poekoeng; ber- KV 75 [118/19

poelak, poelas $118 / 30$

poelang $118 / 30$ poelang sah $160 / 11$

poelau Koetai $154 / 11$

poeloe $174 / 22$

poelih $180 / 29$

poen $137 / 29$

poenai menerdjoeni poeloet $158 / 13$

poentjak reboeng $132 / 13$

poentoe 226/4

poentoeng $136 / 19$

poepoes $122 / 31$

poesar angin 196/25

poesar toeloeng $196 / 25$

poespa pemboedjangan, - papadja-

ngan, - pemadjangan 245/7

poetar; mem- kedaton, mem-

negeri $168 / 19$

poetik; mem-, di-nja 168/11

poetjah-memoetjahkan 140/15

poetjoek reboeng (- rabong) 132/13

poewas 264/23

polah; di-(kan), mem- 141/5

polés $\mathrm{KV} 41$

poléng 126/24

poléng (bang) bintoeloe adji (adi)

ponél 225/2

pontang $136 / 18$

pontjo, - drio 196/1

ponto, - naga $226 / 4$

pontoh 226/4

potos, se-, di-nja 122/1; mem-

lidah radja 209/21

priaji $206 / 17$

radja; ke-an 193/19; be-2an 194/8

raga emas $119 / 10$

r.gan $165 / 19$

rajas ; be- $241 / 2$

rambit; me- $129 / 15$

ramoe; be- $124 / 22$

rangin; me- $250 / 24$

rangin; ng- ngre- $138 / 25$

rantai; pinggan - 165/24

rantas $122 / 1$

ranti ; pinggan - 165/24

rantjah 162/7

rantja $^{\text {s }}$ soedji $132 / 7$

raoen, -2 an $128 / 26$

rapak $143 / 9$ 
rapat; di-inja 195/2

rasa; peng- $163 / 5$

rasah ; be-, toekang - 132/5

ratoe berkoeroeng 207/30

rebak; se- 173/13

redas $\mathrm{KV} 17$

rekap; me- $146 / 31$

réla; dike-i $241 / 10$

rembesing (rembasing) madoe

rénggé $165 / 11$

renik $132 / 2$

rentang; me- 125/13

rentas; me- $122 / 1$

rentjah $162 / 7$

riang; ba-2 120/19

ridis $\mathrm{KV} 19$

rinding $183 / 20$

ringgoeai $150 / 13$

ringkoe, - bajan 174/13

ring-ring $\mathrm{KV} 5$

roemadja $140 / 24$

roembas; be- 196/5

roemroem; menga-, ng- 215/32

roendja; be-2 132/14

roengkoep; di- 154/19

roesak; me-kan 186/33

romo; kandjeng - 215/10

rongkop ; di- 154/19

rotok $190 / 9$

sadedeg penggajoeh $165 / 28$

sagin $128 / 29$

sagoenging $204 / 8$

sahoe $119 / 30$

sain $128 / 29$

sajang; pe-an 207/22

salak; di-nja 172/33

salawat tiga kali $245 / 5$

saloedoee $^{s} 131 / 25$

sampoen $138 / 26$

saroedoees $131 / 25$

samoeng $131 / 16$

sampai $136 / 4$

sampar $143 / 20$

sampéan, sampian 198/34

sangga; penj- darah 165/12

sanggan; sa- $140 / 10$

sangka; penjangkahan 154/6 sangkar; pinggan - 165/21

sangko, sangkoe 154/29

sangkoe, - berwajang 229/17

sangkoeh $154 / 29$

sangkoel; ber- $166 / 27$

sanglir, - sari $227 / 26$

sangoepati $160 / 11$

santana dalam (dalem) 198/21

saoeng (saong); menj-, penj-an,

menj- roempoet $139 / 15$

sapangan 162/18

sapoe $^{2}$ basa $125 / 11$

sapoe djagat $121 / 7$

sara-geni $207 / 14$

saré, pe-an 151/18

sari djajéng katon 131/14

sasar kandang 129/15

saté, se- 206/10

saté asam (asem) 206/12

, garang asam 206/10

, kambit 206/12

sato sembawa $137 / 26$

satoe; ke- $154 / 7$

sawa $122 / 2$

sawat I $201 / 6$

sawat II $132 / 27$

sebarang $158 / 26$

sedakap 145/11

sededak sepengajoeh $165 / 28$

sedoengan $207 / 20$

segaran; soengai - $211 / 18$

sekar delima $211 / 16$

sekéténg; lawang - 223/29

selawat $245 / 5$

selir 227/28

selos (?); njelos $i$ hati orang 209/21

sémbong, -an 206/19

semoempoeng $143 / 5$

sémpol 168/10

sendjata besar $176 / 9$

senggan $140 / 10$

senténg, senting $211 / 14$

sentong $211 / 14$

sepangan $162 / 18$

sepatan; per- $143 / 14$

sepoe $^{2}$ basa(h) $125 / 11$

sepoeh $240 / 16$

seraga $216 / 16$ 
seri menganti $200 / 11$

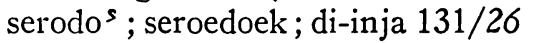
sersilah, inl. § 1

serta; (menj)-i 188/20

setabel $207 / 17$

setinggil $198 / 6$

setjorong $132 / 6$

si - $i$ 125/24

sida $\mathrm{KV} 58$

sidik (tan) pengoetjap 191/25

sigera $118 / 32$

sikoe toenggal; ber- 145/11

simbar dada 160/29

$\sin 128 / 29$

sinalangan $206 / 21$

singsat; di-nja 160/28

singset; $n j$-, nj-aké ,nj-i, 160/28

sinoekoepan 207/29

sinoman 207/16

sintal; di-nja $229 / 25$

sipat alis $131 / 15$

sipat alit; ber- $131 / 15$

sirah 119/14

sirig $126 / 8$

sirik; ber- $126 / 8$

sirip lais ; menj- 132/11

sisa $207 / 24$

siwidja 120/18

soeaka, ber-kan 207/33

soebang bapang 136/29

soegai ; ber- $153 / 18$

soegara mengambang $211 / 9$

soegaran, soengai - 211/18

soegoeh; menj-, nj-(i) 206/6

soekoe toenggal, a-, ber-, $m a-$

soema $165 / 27$

soemahan $165 / 27$

soemangat; ke-an 187/13

soemba $134 / 11$

soemping, sa-, soe- $131 / 11$

soempit; -an 165/32

soepan $220 / 34$

soeraga $216 / 16$

soerai; ber- $126 / 8$

soer.widja $120 / 18$

soeréng pati $160 / 20$

soeroean $165 / 1$ soeroeng; manj-, tanah $n j-(n-)$

soerti $205 / 18$

pelempang $129 / 15$

soesoeran dagang $231 / 5$

soeweng bapang 136/29

sorogeni $207 / 14$

sorong ; menj- 198/4

sotja loedira $144 / 25$

sri menganti $200 / 11$

tadjau kang 154/21

, kangkang 165/23

, lingau (lingoe) 165/18

, nagang $165 / 22$

tadoeng $161 / 8$

tagang; $n-158 / 9$

tahoen tiada (men)djadi, lapas

tahoen, 189/4

taki, be- inl. $\$ 3$

talali 174/14

tali djoeita $131 / 32$

taloe 160/14

tama ; -kan, di-inja 174/8

tamboen, -an, di-kannja 190/5

tambon 122/16

tampa; pen- $137 / 10$

tampoek 156/26

tampoek geloeng, pen- geloeng

tandjal 159/15

$[131 / 13$

tandjoeng 183/20

tanggal $136 / 21$

tanggoeh; ber-, di-i 142/18

tangkalaso $139 / 30$

tangkero $149 / 20$

tanja ; men-i 141/26

taoe-taoe $249 / 17$

taoen; - mandis djadi, salak -, pa-an 189/4

tapak léman 131/29

tapas I KV 10

tapas II 128/18

tapéh (tapih) pasak 136/27

tapoek 156/26

tapoek geloeng 134/13

tarak brata 118/19

tarék 154/27

taroeh, -an 141/20

tatakerama 191/22 
tawak; man- KV 34

tebak; n-, di-nja KV 34

teda; $n$-, n-ni, ami-ni 156/32; zie ook paneda en petedan.

tédja 125/30

tedoeh; men-kan $125 / 8$

tedoeng matahari $161 / 8$

tedong, - ari, - boelan 161/8

tegang, men-, di- $158 / 9$

tegoer, -kan, -an 143/1

tekatan $162 / 11$

telaga ; men- $128 / 6$

telalé, telalik 174/14

telian 123/17

teloe $160 / 14$

teloer; pe-an, teloran 250/18

temanggal $136 / 32$

tembang; men- $216 / 18$

tembérau; men- $149 / 10$

tembokan 140/10

tembokang 140/10

tempat 189/28, 209/14

tempong tawar 251/15

temposo; men- $128 / 6$

tengah; men- hari $131 / 27$

tengar, ber-, bate-, -an 134/8

tenger, te- $134 / 8$

tengkang $131 / 10$

tengkelasa $139 / 30$

tentang; sepen- mata $154 / 10$

tepas ; men-, pen- $128 / 18$

tepoeng tawar; men- $128 / 33$

terada $120 / 2$

terahal $220 / 10$

teraté $131 / 15$

terdjali, terdjeli $\mathrm{KV} 60$

teri; be- $133 / 1$

teroes kedaton, men- 160/19

teroes ing paningal, t. peningal,

t. $\tan$ p. $144 / 22$

terojong; n- 227/22

tersilah, inl. $\S 1$

tetap; men-i 190/10

tetep; $n-i$ 190/10

tiang pandén 132/25

tidjak tanah, men-kan t. 119/29

tigoe $126 / 25$

tikas ; se- $140 / 5$ timbangan $\mathrm{KV} 21$

timboen, -an, men-, di- $128 / 26$

timoen 128/26

tinatah tinatoerangga 131/26

tindak tandoek 205/18

tingal ; pen- $144 / 22$

tipoe-daja; se-koe $163 / 7$

tirisan 139/33

titi soerti $205 / 15$

titir ; di-nja, men-2 148/19

tjakér; men- $215 / 30$

tjaloek; man- hati oerang 209/21

tjampoeh ; ber- 196/18

tjampoer-tjemah KV 43

tjandipoera 185/29

tjangang, di-inja 196/20

tjantjoct, ber- $226 / 3$

tjaram; dipe-kan, ba-, -2, - tangis

tjarem 132/29

tjatoe, men-, di-i 156/32

$[132 / 29$

tjengang, ter-, di-inja 196/20

tjetjerong, tjetjérong 132/6

tjetjorong 132/6

tjindera $\mathrm{KV} 63$

tjita ; men- 188/19

tjoba; ba-2han 202/34

tjoela semi $131 / 16$

tjoela semoeng 131/16

tjoendoek, tja-, tjoe- 136/31

tjoeriga 209/10

tjoetjoeanda $221 / 14$

tjoetjoeh $206 / 10$

tjoetjoek geloeng, - kondé, - mentoel

tjondhoek; tjo- 136/31 [131/12

toa $237 / 24$

toea, toeanda $237 / 24$

toean $240 / 28$

toean ; dipa- (diper-) 145/33

toeboeh $179 / 30$

toedoeh $225 / 12$

toeha; ka-an 122/16

toejali $174 / 14$

toejang papan 137/24

toekan 136/23

toclak di KV 51

toelali 174/14

toelang (se-) 126/25

toeli ; air - $229 / 16$ 
toelian $123 / 17$

toembak gandjoer $136 / 18$

toempah, $n$-kan 221/11

toempang $139 / 30$

toempang; $n$ - $149 / 20$

toempong $174 / 13$

toenggak semi $131 / 16$

toenggal 136/21

toenggangan $166 / 32$

toenggoek $207 / 16$

toentoen; -an, man- 131/32

toentoet; men-i, di-i 143/4

toeroen; men-kan ketepian 120/2

toeroen tangis $186 / 6$

toesing kesoema 119/21

toesoek kondé, - mentoel 131/12

toetoek; men- $173 / 2$

toetoep; an-i 160/26

toetoes $119 / 21$

toerva $237 / 24$ tombak p.nt.ng, - poentoeng, pontang 136/19

tompong, -2 174/13

topéng ; di-kan 134/31, ber-

totokromo $191 / 22$

$[225 / 35$

wajah $144 / 13$

wajang; di-kan 134/31

wala-wala $146 / 26$

walang $220 / 33$

waloe $132 / 11$

wanita $209 / 10$

wantjak soedji $132 / 7$

warna, - bagai $236 / 33$

wédjén $124 / 4$

wéla ${ }^{2}$ wélo 2 196/20

widja 120/18

widjén, zie wédjén

widjil, -ing 119/20 


\section{NAA M R E G STER}

Opgenomen zijn alleen de in de tekst voorkomende namen van personen, geografische namen en stamnamen, naar de spelling der uitgave, voorzover niet in de aantekeningen verbeterd. Zie verder de opmerkingen aan het eind van $\S 2$ der inleiding. Om het naslaan te vergemakkelijken zijn de op bl. 258-262 voorkomende namen voorzien van regelaanduiding, de op andere plaatsen voorkomende slechts. als er in de commentaar iets over is opgemerkt.

Adji Abang 258/25

A. Ahmad $261 / 23$

A. Asan $261 / 24$

A. Amdjah $260 / 34,261 / 6$

A. Andoet $260 / 34,261 / 7$

A. Bagawan $260 / 11$

A. Bangbang, zie A. Abang

A. Baroe $260 / 35,261 / 26$

A. Basok 261/35

A. Batara Agoeng Déwa Sakti, zie Batara A. D. S.

A. Batara Agoeng Padoeka Nira, zic Padoeka Nira

A. Beranak 258/21

A. Bini Kesoemaningrat 262/6/16

A. Boengsoe 261/25

A. Daing 260/32, 261/4

A. Dajang Boedjang 258/28, $259 / 22$

A. Dajang Pandjang 258/12

A. Dali $261 / 17$

A. di Astana 258/10, 259/36

A. didalam Tadjau 186, $259 / 26$

A. di Gedoeng 246, 249, 258/18/26

A. di Keranda $258 / 11,260 / 2$

A. di Langgar 246-250, 258/10/13, $259 / 33$

A. di Makam 247, 249, 259/1/33

A. di Roebian $259 / 28$

A. di Roebian Moeda 259/29

A. di Toendjoeng 259/4

A. Djaitan Lajar $259 / 25$

A. Doeri 248

A. Doja $260 / 25$
A. Emas Tjeki (= A. Mas Tjeki, A. Tjeki of Tjili) $261 / 7 / 17 / 21$

A. Emong (Mong) 262/11/25

A. Empang $260 / 35$

A. Gahar 262/1

A. Ganti $260 / 12$

A. Gedé I $260 / 23$

A. Gedé II $261 / 7 / 27$

A. Goendang $261 / 33$

A. Goeroe $261 / 16$

A. Idris $260 / 18$

A. Intan $261 / 4$

A. Ipok $260 / 33$

A. Kanderi $261 / 18$

A. K.toen $262 / 7 / 18$

A. Kédok $261 / 8$

A. Kesoema $262 / 3$

A. Kingsan 260/30, 261/3

A. Koendang 261/33

A. Koening 259/30

A. Koentjar 262/7/14

A. Koepang 261/34

A. Koesan 262/7

A. Limar $262 / 8$

A. Limau $261 / 19$

A. Lipi $261 / 15$

A. Maimoenah $261 / 24$

A. Majang $260 / 22$

A. Mandarsah $259 / 28$

A. Marsil 248

A. Mas Aria 261/7

A. Masti $262 / 10$

A. Mas Tjeki (Tjili) zie A. Emas

A. Mérah 262/8

$[\mathrm{Tj}$. 
A. Mertjoe $261 / 19$

A. Moedra $261 / 20$

A. Mong, zie A. Emong

A. Natoeng $262 / 7 / 18$

A. Negara 260/35, 261/7

A. Oelang $258 / 23$

A. Oemboet $260 / 30,261 / 2$

A. Oendang $261 / 29$

A. Oengoe $261 / 18$

A. Oenoes $262 / 2$

A. Oenok 261/32

A. Padoeka Nira, zie Padoeka

A. Pandjang 249

A. Pati $260 / 19$

A. Pegang $260 / 33$

A. Poentja $260 / 32$

A. Poeteri I $258 / 11$

A. Poeteri II $261 / 10$

A. Poeteri Agoeng 260/28, 261/7

A. Poeteri di Keramat 261/5

A. Poeteri Kesoemaningrat $262 / 20$

A. Radén Moeda 260/20

A. Radén Poetera 247

A. Radén Tilak $261 / 16$

A. Radén Tjakranegara, zie Radén $\mathrm{T} \mathrm{j}$.

A. Radén Toea $260 / 20$

A. Radén Widjaja 239, 244-247, 249, 259/2

A. Ragi (Regai ?) $260 / 5$

A. Ramboeti $258 / 23$

A. Ratoe Agoeng Kesoemaningrat $262 / 17$

A. Ratoe Moearakaman 261/12

A. Roebat 248

A. Saléh $262 / 9$

A. Seman $261 / 34$

A. Sinoem 261/19

A. Siroe $261 / 20$

A. Siti $260 / 21$

A. Taténg $262 / 5$

A. Tengah I $258 / 15$

A. Tengah II $261 / 25$

A. Tengahan $258 / 21$

A. Tepa $261 / 18$

A. Tepoe $261 / 20$

A. Tjeki, zie A. Emas Tjeki

A. Tobo $261 / 10$
A. Toepang $260 / 32,261 / 5$

A. Wati $261 / 15$

A. Wiroebian, zie A. di Roebian 'Alioeddin (Soeltan -) 261/8 Anak Aria Si Ranggamarta 253 Anak Bajan 259/17

A. Baloe 259/14/19

A. Boedjang $258 / 34$

A. Boengsoe $259 / 10$

A. Dalam $259 / 15 / 21$

A. Dalam di (H)Ilir 258/22

A. Langga $259 / 8$

A. Rangga 248

Aria Bantan 259/19

Aria Ranggamarta 259/16 (vgl. 253/2)

Aria Wangsakesoema 258/35

Aria Wargakesoema 259/20

Aroeng Penéki 260/26

Awang Seradjang 253, 256

Baboe Djaroema 118, 121-127, 137-138, 157, 161-165, 170

Badjau 130, 248

Bajan Sampit, zie Kebajan S.

Balikpapan 244

Bandjar 258/25

Banō (?) $178 / 21$

Basap 143

Batara Agoeng Déwa Sakti (Adji -) 128-134, 140-145, 149-150, 152, 157-158, 161, 165-166, 169

Batara Agoeng Padoeka Nira, zie Padoeka Nira

Benaloe, zic Binaloe

Bengalon 172, 174, 179-180, 182-

Beras Basah 133/12 [183

Berau 143

Berma Widjaja, zie Maharatoe B. W.

Beroenai 144-145, 148-149, 152, 159

Binaloe 118/11, 133, 166-168, 172 . 185

Boentang (Bontang) 130, 133, 248/?8

Daing Koenjit (?), zie Dajang $\mathrm{K}$. 
Daja 143

Dajang Abing 261/31

Dajang Andoe 261/32

Dajang Boerat 258/32

Dajang Doerat 258/36

Dajang Kidak 261/23

Dajang Koenjit 261/14

Demang Djaitan Lajar (Ki -, Kiai -) 128, 130, 133-134, 140, 144,153

Dermasetia (Toean -, Maharadja -) 253, 255, 256

Déwa Adji Radja Poeteri, zie Radja P.

Déwa Darmadéwa 160/2

Déwa Mangkat 259/25

Déwa Poeteri 185, 189, 226, 229230, 259/5 (laatste foutief)

Dipatoean (Dipertoean, soms Jang -) $145-151,159$

Djaitan Lajar 118/9, 128-130, $134-135,141,152,164,172$, 183-185

Djaroema 162

Djawa 153, 191, 202

Djoendjoeng Boejah (Boeih) (Poeteri -) 136-137, 139-140

Doendang (Dondang) 133/29, 186

Entjik Awang Tempoetok 261/28

Gadjah Mada (Meda, Patih -) 167, 197-198, 202-205, 212-213, 216, 221-224

Goenoeng Angkat-angkatan 189, 250

Goenoeng Djaitan Lajar 118, 142-144

Goenoeng Kemoening 133

Goenoeng Toenan (Tenoenan) $160 / 2$

Hoeloe Doesoen, zie Oeloe D.

Kampoeng Pandji 261/22

Kampoeng Tengah 258/27

Kanioengan 133, 143, 244

Karamoemoes $134 / 12$
Karangasan 134/12

Karang Melenoe (Poeteri -) $127-129,133-135,156,160$

Kebajan (Ki Bajan ?) Sampit 252,

Kéham 174/26

Kembang 133/28, 186

Kenangan 133/9

Ki Djipati Anoem 258/31

Ki Djipati Djajaperana 251, 259/34

Ki Djipati Kesoemajoeda 258/32

Ki Djipati Mandoera 248, 250, $253,256,258 / 16$

Ki Djipati Mangkoejoeda 248, $250,252,255,256,258 / 16$

Ki Djipati Poegar 248, 253, 258/34

Ki Djipati Sendjata 248, 250, 252, $255,258 / 15 / 30$

Ki Djipati Soerjanata 258/20

Ki Djipati Tempasana 258/28, $259 / 22$

Ki Mas Antasari 249, 258/29

Ki Mas Djenggala 249

$\mathrm{Ki}$ Mas Lelangoen 246, 248

Ki Mas Sabini 258/33

Ki Mas Sekoeti 249, 258/26

Ki Narangbaja, zie Narangbaja

Ki Rangga Toea, zie Rangga $\mathrm{T}$.

Koeran 143/20, 178

Koetai (Karta Negara) passim

Kotabangoen 257

Labda 252, 253, 255

Loah Bakoeng 134/13, 244

Madjapa(h)it 153, 159, 166-167, 191, 195, 197-198, 200-204, 208, 210

Mahakam 125, 169, 170

Maharadja Bermawidjaja, 179198, 200-203, 205-206, 209-210

$212,214,223-224$

Maharadja Dermasetia, zie D.

Maharadja Dermawangsa 184, $187-188,194-195,203,224$, 227-228, 230, 232

Maharadja Indramoelia 194-204 
Maharadja Indrawangsa 184, 186, Ngabé(h)i Tjatjak (Tjetjak) 253. $188,203,224,227-228,230,232$

Maharadja Sakti 184, 186-187, 189-191, 193-195, 198-205, 212, 216, 221-224, 226-234, 237

Maharadja Soeltan 185, 187-195, 197-214, 223-236, 239, 259/27

Maharadja Soerawangsa 184 , 187-189, 195, 203, 224, 227-228, Oeloe Doesoen 118/10, 128-130, 230,232

Maharadja Talikat 257, 258/6

Manggar 133/29

Mangkoepalas 134/14

Mangkoeradja $174 / 26$

Mangoen di Poera 246/33

Marakaman, zie Moearakaman

Marangkajoe 133

Marantjaloeng 260/14

Marhoem di Koetai 261/2

Marhoem (di) Kembang Mawar $262 / 13$

Marhoem Mandarsah 259/34

Marhoem Pemarangan 260/10/16

Matan 152

Mataram 145, 147

Melanti 118/4, 121

Menamang 179, 180

Mengkanjing 172/21

Mengkasar 240

Menoebar 244/9

Menteri Oedjoeng Bali 253, 256

Meragoei 172-183

Minak Mampi (Njai -) 129, 133, 164, 169-170, 172, 179

Moearakaman 174, 194-195, 204, 249, 252-257

Moeara $\mathrm{Pa}$ (h)oe 249

Moehammad Idris (Soeltan -) 260/19/24/26, 261/1

Moehammad Moeslihoeddin (Soel$\tan$-) 261/3/9/30, 262/12

Moehammad Salihoeddin ing Martapoera 262/15/33

Narangbaja (Ki -) I 252-253

Narangbaja (Ki -) II 257-258

Ngabé(h)i Oeloe Doesoen 128, $130,133-135,137-140$

256

$\mathrm{Njaï} \mathrm{Bini} \mathrm{Petinggi}=\mathrm{Njai}$

Djaitan Lajar

Njaï Djaitan Lajar 120-121

Njai Mampi, zic Minak Mampi

Njaï Tamboen 247-248

$134-135,140,158,164-165$, 172,185

Oengkal 133/9

Padoeka Nira (Adji -, Batara Agoeng P.N., Adji B.A.P.N.) $166,171,181-183,185,189$, 224, 259/26

Padoeka Soeri (Poeteri -) I 172173, 175, 177, 179-180, 183

Padoeka Soeri II 232-233

Pahak 257/33

$\mathrm{Pa}$ (h)oe 248

Pandansari 133/12, 186

Pangéran Anom I 249, 258

P. Anom II 262/24/28

P. Anom Pandji Mendapa ing Martapoera 260/9

P. Ber(a)djanata I 261/6/13

P. Ber(a)djanata II $262 / 23 / 28$

P. Dibaloe 249

P. Dipati $262 / 25 / 30$

P. Dipati Agoeng ing Martapoera 260/1

P. Dipati Madjakesoema ing Martapoera 260/3

P. Dipati Toea ing Martapoera 260/6

P. Ditoeradja $260 / 4$

P. Djembangan $260 / 7$

P. Kertanegara 249, 258/18

P. (Aria) Mangkoenegara 261/21

P. Poerbaja 258/25

P. Praboe (Anom Kesoemaningrat) 262/18/31

P. Roebian Anom 259/31

P. Sinom Pandji Mendapa ing Martapoera 248, 250-253, $255-257,258 / 13,259 / 35$ 
P. Temenggoeng I 145, 147, 149-152

P. Temenggoeng II $=$ P. T. Bajabaja

P. Temenggoeng Bajabaja 237-240, 259/30

Pantoen 260/15

Pasir 174, 237-239, 258/24, 260/24

Penembahan (van Pasir) 258/24

Penjawangan (Penjoewangan) $133 / 27,186$

Permata CAlam 237-238, 240, 245, 259

Peta Sebengarang 260/25

Petinggi Djaitan Lajar 118-120, 153-154, 164

Petinggi Oeloe Doesoen 121-125

Podjo 259/9

Poelau Atas 134/12

Poelau Lindoer 130/12

Poelau Pandjang 130/11

Poelau Semanti 130/9

Poentjan Karna 231-235

Radén Aria Pepatih 259/18

Radén Bangsa 247, 259/11

R. Boengkoek 260/16

R. Demang 259/20

R. (Emas) Patih 259/17 v.

R. Mas Tjili 262/26

R. Poespanegara 262/3/24

R. Poetera 259/13

R. Soeramenggala $260 / 16$

R. Tirtanegara $262 / 2 / 23$

R. Tjakranegara (Adji -) 262/1/22

Radja di Astana 259/32

Radja Makota 239-247, 259/31

Radja Mandarsah 235-240

Radja Poeteri I (Déwa Adji -) $185,189,233-236,259 / 5$ (verb.)

Radja Poeteri II 237-239

Radja Tjina 140-143

Ranggajoeda 252-253

Ranggapoespa $259 / 14$

Rangga Toea (Ki -) 249, 259/6

Ratoe Agoeng I 244-246

Ratoe Agoeng II 260/5

Ratoe Agoeng III 260/12
Ratoe Agoeng IV 260/22

Ratoe Agoeng V 261/11

Ratoe Agoeng di Roembia 260/13

Ratoe Emas Kentjana Oengoe $159 / 32$

Ratoe Gedé 249, 258/19

Ratoe Mangkoerat 248, 258/29

Ridjang 133/13

Rigang $133 / 13$

Sambas 152

Samboejan 133/30

Sangata 179

Sangkoelirang 142, 179, 244

Sangsangan 133/28, 186

Santan 133, 179

Santan Dalam 133

Satiagoena 253, 255, 256

Satiajoeda $253 / 8$

Sembaran 118/10, 133, 166-168, 172,185

Sembéra 133/10

Semboejoetan 134/13, 186

Senawan $133 / 27,186$

Seri Gembira 235-238, 259/4

Seritama 253, 256

Soekadana 152

Soengai Samir 133/29

Soengai Sediwé 125/17

Soesoeran Dagang 133/30

Tabos $143 / 19,178$

Tanah Malang 133/31

Tanah Mérah 133

Tandjoeng Semat 133/14

Tandjoeng Parangan 125/2

Tandjoeng Riwana 125/3, 169-170

Tepian Batoe 125/2, 165

Tjina 140-143

Toean CAli 261/26

Toean Daham 260/21

Toean Dalam 258/35

Toean Dermasatia, zie Dermasatia

Toean di Bandang 240/28

Toean di Parangan (= T. Hadji di P., T.P., T. Toenggang P.) 240 , 243, 245-246

Toean Katak 247-248 
Toean Koetjang 249, 256, 259/7 v. Toean Timpang 246, 248

Toean Milan 248/17

Toean Narsih 246, 248-249

Toean Toenggang Parangan, zie

Toean Parangan, zie T. di P. Toean di P.

Toean Pengoeloe 248

Toean Rapat 247

Toean Rimah I 246

Toean Rimah II 247-248

Toean Tegaran 258/16

Toean Wali 248

Toemenggoeng Kioeng 239

Toendjoeng 231

Wadoe Adji 246-247, 249, $259 / 5 \mathrm{v} . / 11 / 16$ 


\section{LIJST DER VOORNAAMSTE A F KORTINGEN}

Aanh. vdW

atj.

B

Bab natah

bal.

batav.

bdj.

Bespr.

Bnt.

boeg.

boek.

boes.

bp.

br.

Bijdr
- Aanhangsel op het Maleisch-Nederlandsch woordenboek van $\mathrm{H}$. von de Wall, bewerkt door $\mathrm{H}$. N. van der Tuuk en uitgegeven door $\mathrm{Ph}$. S. van Ronkel, Batavia 1897.

- Atjéhs.

- Berlijns handschrift der Salasilah, zie inleiding $\S 1$.

- Bab natah sarta njoengging ringgit watjoetjal, anggitanipoen Soekir. Volkslectuur serie no. 244, Batavia 1935.

- Balinees.

- Maleis van Batavia.

- Bandjarees.

- Boekbespreking van Dr. C. A. Mees, De Kroniek van Koetai, TBG 77, 1937, 294 vv.

- in een noot der tekstuitgave opgegeven lezing van hs. B, zie inleiding $\$ 2$.

- Boeginees.

- Waarschijnlijk bedoeld Boekits [red.].

- Boesangs.

- Basaps. Naar gegevens ontleend aan twee door Mr. A. J. M. Zijlmans, toenmalig adspirant-controleur van Sangkoelirang, in 1940 ingevulde blanco-woordenlijsten. De gegevens betreffen twee dialecten, het ene gesproken in de kampongs Kerajaan, Saka en Mandoe, het andere, het z.g. Dajat-dialect (niet te verwarren met Daja), in de kampongs Moeara Bai, Karangan, Tintang, Lembak, en Lesan (de laatste in Berau).

- Maleis van Broenai. (Woordenlijsten van H. S. Haynes, JSBRAS 34, bl. 39-48, Marshall met aantekeningen van Moulton, ib. 83, bl. 45-74, G. T. MacBryan, ib. 86, 376 v.).

- Bijdragen tot de Taal-, Land- en Volkenkunde, uitgegeven door het Kon. Instituut voor de Taal-, Land- en Volkenkunde van Ned.-Indië te 's-Gravenhage. 
De Clercq

Endert Exp

GR

Hik.

Hik. Atjéh

Hik. Radja ${ }^{2}$ Pasai

Hik. Rahwana
- F. S. A. de Clercq, Nieuw Plantkundig woordenboek voor Nederlandsch Indië, tweede, herziene en vermeerderde druk, bewerkt door Dr. A. Pulle, A'dam 1927.

- F. H. Endert in Midden-Oost-Borneo Expeditie 1925, Weltevreden 1927, bl. 117-312.

- J. F. C. Gericke en T. Roorda, JavaanschNederlandsch woordenboek, verm. en verb. door Dr. A. C. Vreede, A'dam-Leiden 1901.

- Hikajat.

- Hikajat Radja Atjéh, naar hs. Leiden Cod. Or. 1954.

- Hikajat Radja-radja Pasai, naar de uitgave van Éd. Dulaurier, Paris 1849.

- Hikajat Rahwana, Bandjarees-Maleise tekst, naar een handschrift der Mallinckrodt-Stichting.

Hik. Sri Rama Maxw.- W. E. Maxwell, Sri Rama, JSBRAS 17, 1887.

hs(s). - handschrift(en).

hs. Bat. Gen. 295 - Pandji Narawangsa-handschrift van het Bataviaasch Genootschap. (Gedeeltelijk uitgegeven door Volkslectuur, serie no. 1246, 1936).

I

- fotografische reproductie van een te Leiden berustend hs. der Salasilah, toebehorend aan het Bataviaasch Genootschap (Mal.hs. K.B.G. 461), zie inleiding $\S 1$.

Irawan Rabi - Irawan rabi, mitoeroet katrangan-katrangan anggitanipoen $\mathrm{Ki}$ Redisoeta. Volkslectuur serie no. $1037,1932$.

jav. - Javaans.

J. en P. - J. E. Jasper en Mas Pirngadie, De Inlandsche Kunstnijverheid in Nederlandsch Indië, 5 dln, 's-Gravenhage 1912-1930.

JMBRAS

JSBRAS

$\mathrm{K}$

Kamoes

KBW

Klinkert
- Journal of the Malayan Branch of the Royal Asiatic Society.

- Journal of the Straits Branch of the Royal Asiatic Society.

- handschrift der Salasilah in het bezit van den heer S. C. Knappert, zie inleiding $\S 1$.

- M. Thaib gl. St. Pamoentjak, Kamoes bahasa Minangkabau - bahasa Melajoe-Riau, Batavia 1935.

- H.N.van der Tuuk, Kawi-Balineesch-Nederlandsch woordenboek, Batavia 1897-1912.

- H.C.Klinkert, Nieuw Maleisch-Nederlandsch woordenboek, derde verb. en verm. druk. Leiden 1916. 

koet. $\quad$ - Maleis van Koetai.
KV $\quad$ - korte versie der Salasilah, zie inleiding $\S 5$.
litt. $\quad$ - litterair, niet behorend tot de spreektaal.
mad. _ Madoerees.
mak. - Makassaars.
mal. - Maleis.
md.-mal. _ Midden-Maleis.
Mees - Dr. C. A. Mees, De Kroniek van Koetai.
Tekstuitgave met toelichting, Santpoort 1935
min. - Minangkabaus.
$\mathrm{N} \quad-$ Tenggarongs handschrift der Salasilah, zie inleiding $\S 1$.
n.f. $\quad-$ nisi fallor, als ik mij niet vergis [red.].
ng. $\quad-$ Ngadjoe.
Oend. B. N. - Oendang-oendang Beradja Nanti, uitg. en vert. door Dr. C. A. Mees in Adatrechtbun- del 39, 's-Gravenhage 1937, bl. 300-340. Bij de aanhalingen hieruit is gebruik gemaakt van een collatie van twee Tenggarongse hand- schriften.
ojav. - Oud-Javaans.
ontbr. $\quad$ - ontbreekt, zie inleiding $\S 2$.
Pigeaud - Dr. Th. Pigeaud, Javaans-Nederlands hand- woordenboek, Groningen-Batavia 1938.
$\mathrm{S}$
- het z.g. ",Sultanshandschrift” der Salasilah, zie inleiding $\S 1$.
Sa $\quad-$ Tenggarongs handschrift der Salasilah, zie inleiding $\S 1$.
Sal. $\quad$ - Salasilah van Koetai.
sas. $\quad$ - Sasaks.
sd. $\quad$ - de taal der z.g. Sea Dyak, naar W. Howell and D. J. S. Bailey, A Sea Dyak Dictionary, Singapore 1900.

Sedj. Melajoe - Sedjarah Melajoe, geciteerd naar de vijfde druk van Shellabear's uitgave in Arabisch karakter, Singapore $1343 \mathrm{H}$.

ser. $\quad$ - Maleis van Serawak.

Sj. Ganda Kesoema - Sjacir Ganda Kesoema, Bandjarees-Maleise tekst, naar een handschrift der MallinckrodtStichting.

Sj. Hémop - Sjacir Hémop, geciteerd naar J. Rusconi. Sja'ir Kompeni Welanda berperang dengan Tjina, Wageningen 1935.

snd. $\quad$ - Soendanees.

Snouck Hurgronje - C. Snouck Hurgronje, Nog iets over de Salasila van Koetei. Bijdr. 5 de volgr., dl. 3, 1888, bl. 109-120. 


\begin{tabular}{|c|c|c|}
\hline syn. & - & $\begin{array}{l}\text { synoniem. } \\
\text { Tromp's handschrift der Salasilah, zie in- } \\
\text { leiding } \& 1 \text {. }\end{array}$ \\
\hline $\mathrm{Tb}$ & - & $\begin{array}{l}\text { vermoedelijk afschrift van het voorgaande. } \\
\text { berustend bij het Bataviaasch Genootschap. }\end{array}$ \\
\hline TAG & - & $\begin{array}{l}\text { Tijdschrift van het Koninklijk Aardrijkskun- } \\
\text { dig Genootschap. }\end{array}$ \\
\hline rBG & - & $\begin{array}{l}\text { Tijdschrift voor de Taal-, Land- en Volken- } \\
\text { kunde van Ned.-Indië, uitg. door het Kon. } \\
\text { Bataviaasch Genootschap van K. en W. }\end{array}$ \\
\hline adj. & - & Tocndjoengs. \\
\hline & & voor \\
\hline 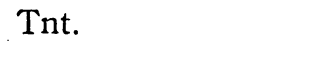 & - & $\begin{array}{l}\text { in een noot der tekstuitgave opgegeven lezing } \\
\text { van hs. T, zie inleiding } \S 2 \text {. }\end{array}$ \\
\hline oev. Oend. B.N & - & $\begin{array}{l}\text { Toevoegsel op de Oendang-oendang Beradja } \\
\text { Nanti, handelend over de bruidschat van } \\
\text { vorstendochters (vgl. Ph. S. van Ronkel, Het } \\
\text { Maleische adat-wetboek van Koetai, Med } \\
\text { Kon. Akad. Wetensch. A'dam, afd. letter- } \\
\text { kunde deel } 80 \text {, serie B, A'dam 1935, bl. 161- } \\
\text { 166), geciteerd naar een Tenggarongs hand- } \\
\text { schrift. }\end{array}$ \\
\hline Tron & - & $\begin{array}{l}\text { S. W. Tromp, Uit de Salasila van Koetei, } \\
\text { Bijdr. 5de volgr., dl. } 3,1888 \text {, bl. } 1-108 \text {. }\end{array}$ \\
\hline U. & & H. N. van der Tuuk. \\
\hline ax & & $\begin{array}{l}\text { H. von de Wall, Maleisch-Nederlandsch } \\
\text { woordenboek, uitg. door H. N. van der Tuuk. } \\
\text { Batavia 1877-1884. }\end{array}$ \\
\hline $\mathrm{VE}$ & - & $\begin{array}{l}\text { st van de Tadjoessalatin, zoals gepubli- } \\
\text { rd door P. P. Roorda van Eysinga in „De } \\
\text { on aller koningen”, Batavia 1827. }\end{array}$ \\
\hline $\mathrm{db}$ & - & $\begin{array}{l}\text { R. J.Wilkinson, A Malay-English Dictionary. } \\
\text { Mytilene } 1932 \text {. }\end{array}$ \\
\hline
\end{tabular}




\section{N H O U D}

TEN GELEIDE . . . . . . . . . . . . . . . . . V V

VOORWOORD . . . . . . . . . . . . . . . . . VII

INLEIDING . . . . . . . . . . . . . . . . . . 1

1. Nieuwe handschriften . . . . . . . . . . . . 1

2. Inrichting en aard van de commentaar . . . . . . 9

3. Enkele opmerkingen over taal en stijl der Salasilah . . 13

4. Elementen van vreemde oorsprong in de Salasilah . . 22

5. Een korte versie van de Salasilah . . . . . . . . 28

6. De Sedjarah Noesentara . . . . . . . . . . 30

COMMENTAAR . . . . . . . . . . . . . . . 32

BIJLAGE: Soerat asal keradjaan Koetai djenang-berdjenang 154

Aantekeningen op de bijlage . . . . . . . . . . . . . . 167

KLAPPER . . . . . . . . . . . . . . . . . . 169

NAAMREGISTER . . . . . . . . . . . . . . 183

LIJST DER VOORNAAMSTE AFKORTINGEN . . . . 189 